\title{
Comunicação na promoção da alimentação saudável via rótulos: uma análise dos discursos
}

Francine Cruz de Cerqueira Lima

Dissertação apresentada ao Programa de PósGraduação em Nutrição em Saúde Pública para obtenção do título de Mestre em Ciências, Programa de Nutrição em Saúde Pública, na Faculdade de Saúde Pública.

Área de concentração: Nutrição

Orientador: Prof. Dr. Carlos Augusto Monteiro 
É expressamente proibida a comercialização deste documento, tanto na sua forma impressa como eletrônica. Sua reprodução total ou parcial é permitida exclusivamente para fins acadêmicos e científicos, desde que na reprodução figure a identificação do autor, título, instituição e ano da dissertação. 


\section{RESUMO}

Introdução: O papel da rotulagem como instrumento de promoção da alimentação saudável depende da adequação de sua linguagem aos objetivos da política pública.

Objetivos: Revisar a literatura científica sobre a comunicação com o consumidor por meio da rotulagem nutricional e da rotulagem relativa a impactos socioambientais em embalagens de alimentos; entender como se formam os discursos sobre alimentação saudável na rotulagem; e elaborar propostas para fortalecer o efeito dos rótulos como instrumento de promoção da alimentação saudável.

Métodos: Busca não sistemática de estudos sobre a comunicação via rótulos de alimentos em bases de dados do campo da saúde e multidisciplinares; e análise qualitativa do discurso de embalagens de "cereais matinais", selecionadas a partir do ethos da marca.

Resultados e discussão: A revisão traz estudos de recepção que apontam um mau aproveitamento dos rótulos pelos consumidores devido à linguagem excessivamente técnica; poucos estudos de emissão exploram o efeito de elementos visuais e verbais com apelo emocional na comunicação. A análise empírica do corpus, delimitado por quatro ethe (imagens de si criadas pelas marcas), mostra que o design das embalagens modula a geração dos sentidos, criando uma hierarquia para as mensagens capaz de reduzir o efeito das informações obrigatórias. Propõem-se novos caminhos para melhorar a comunicação sobre alimentação saudável e sustentável nos rótulos.

Conclusão: A comunicação sobre aspectos nutricionais e socioambientais da alimentação via rótulos, tal como prevista na legislação atual, prejudica seu papel como instrumento de promoção da alimentação saudável. Para transmitir as mensagens conforme o pretendido pela Política Nacional de Alimentação e Nutrição, é preciso rever as informações priorizadas, repensar o design e aprimorar a linguagem, a fim de controlar melhor os efeitos de sentidos gerados.

Descritores: rotulagem de alimentos; rótulos; política alimentar; nutrição; sustentabilidade; promoção da saúde; análise qualitativa; análise do discurso; marketing nutricional; comunicação; linguagem; discurso. 


\section{ABSTRACT}

Introduction: The role of labeling as a tool for promoting healthy eating depends on the adequacy of their language to the objectives of public policy.

Objective: To review the scientific literature on communication with the consumer through nutritional labeling and the labeling related to social-environmental impacts in food packages; to understand how the discourses about healthy eating are formed in food labeling; and to develop proposals to strengthen the effect of food labels as a tool for promoting healthy eating.

Methods: Nonsystematic search of studies on communication in food labels in health and multidisciplinary databases; and qualitative discourse analysis of the labels of "cereals", selected from the ethos of the brand.

Results and discussion: The review brings reception studies that indicate a poor use of labels by consumers due to excessively technical language; few studies explore the effect of visual and verbal elements with emotional appeal in communication. The empirical analysis of the corpus, bounded by four ethe (images of themselves created by the brands), shows that the design of the package modulates the generation of meaning, creating a hierarchy of messages that is able to reduce the effect of mandatory information. Alternatives for the communication about healthy and sustainable eating in food labels are suggested.

Conclusion: The communication on nutritional and social-environmental aspects of food in food labels, according to legislation, jeopardizes its role as an instrument for promoting healthy eating. To convey the message as intended by the National Food and Nutrition Policy, it is recommended to review the prioritized information in labels, to rethink the design and to enhance the language in order to better monitor the effects of meanings generated.

Descriptors: food labeling; labels; food policy; nutrition; sustainability; health promotion; qualitative analysis; discourse analysis; nutritional marketing; communication; discourse. 


\section{ÍNDICE}

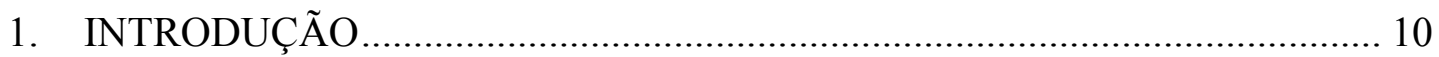

1.1. PROMOÇÃO DA ALIMENTAÇÃO SAUDÁVEL ...................................... 14

1.2. ROTULAGEM DE ALIMENTOS: UM PANORAMA ……………………...... 48

1.3. LEGISLAÇÃO DE ROTULAGEM NO BRASIL ......................................... 80

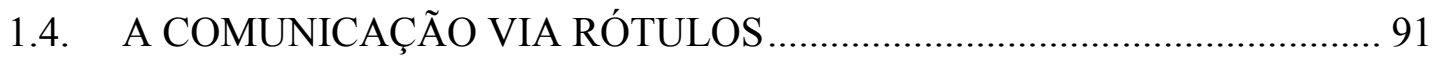

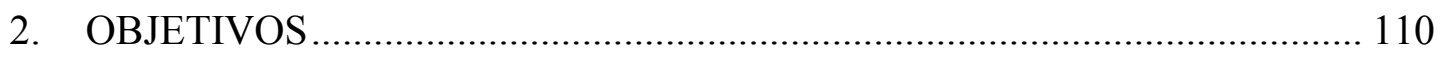

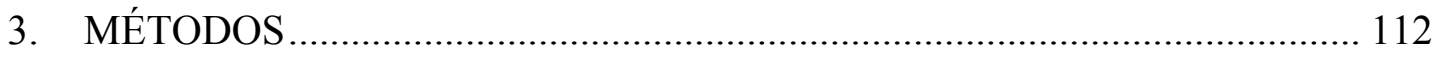

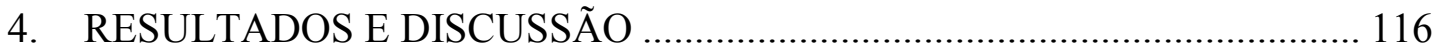

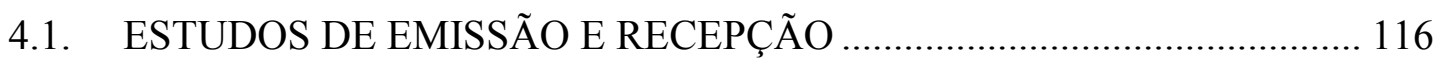

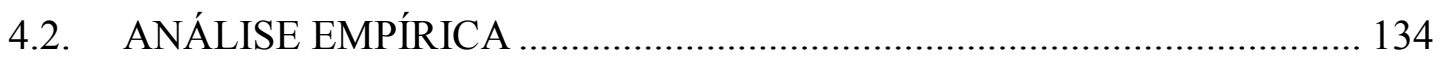

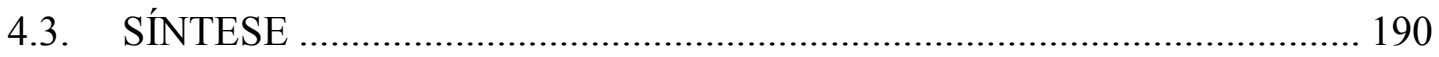

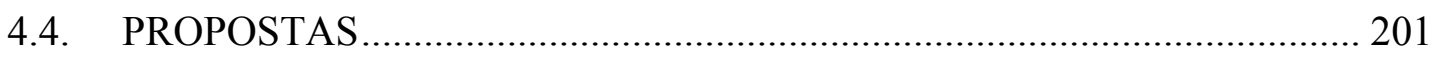

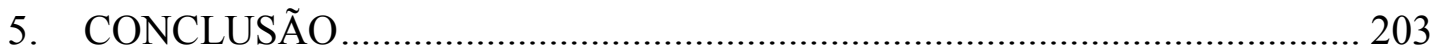

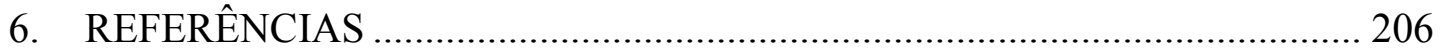




\section{LISTA DE SIGLAS E ABREVIAÇÕES}

$\mathrm{AD}$ - Análise do discurso

Anvisa - Agência Nacional de Vigilância Sanitária

ATNI - Access To Nutrition Index

CFM - Conselho Federal de Medicina

Consea - Conselho Nacional de Segurança Alimentar e Nutricional

EUA - Estados Unidos da América

FAO - Organização de Agricultura e Alimentação das Nações Unidas

FDA - Food and Drug Administration

FOP - front-of-package

GDA - guidelines daily amounts

GAPB - Guia Alimentar para a População Brasileira

Idec - Instituto Brasileiro de Defesa do Consumidor

IMC - Índice de Massa Corporal

INC - informação nutricional complementar

IOM - Institute of Medicine

MAPA - Ministério da Agricultura, Pecuária e Abastecimento

Mercosul - Mercado Comum do Sul

MDA - Ministério do Desenvolvimento Agrário

NLEA - Nutrition Labeling and Education Act

ODBA - Orientações Dietéticas Baseadas em Alimentos

OGM - organismo geneticamente modificado

OMS - Organização Mundial de Saúde 
ONG - Organizacão Não Governamental

PNAN - Política Nacional de Alimentação e Nutrição

RDC - Resolução de Diretoria Colegiada

SAC - Serviço de Atendimento ao Consumidor

SBC - Sociedade Brasileira de Cardiologia

SVS/MS - Secretaria de Vigilância Sanitária do Ministério da Saúde

USDA - Departamento de Agricultura dos Estados Unidos

USP - Universidade de São Paulo

\%VD - percentual das necessidades diárias

VDR - valores diários recomendados

WFM - Whole Foods Market 


\section{LISTA DE FIGURAS E IMAGENS}

Figura1. Modelo de rotulagem nutricional frontal do Facts Up Front. 57

Figura 2. Semáforo nutricional. 58

Figura 3. Ícones aplicados pela empresa de varejo Wegmans Wellness Keys a $\begin{array}{ll}\text { produtos da marca própria. } & 58\end{array}$

Figura 4. Placa com os ícones que informam as qualidades nutricionais do produto exposto numa loja da rede Hortifruti. 58

Figura 5. Selo do programa Choices (Minha Escolha) nas versões norte-americana e brasileira. $\quad 59$

Figura 6. Selo Whole Grain nas versões básica e 100\%. 60

Figura 7. Modelo misto e rotulagem nutricional para a parte da frente da embalagem proposto pela Food Standard Agency no Reino Unido. 66

Figura 8. “Árvore da rotulagem".

Figura 9. Modelo de rotulagem nutricional criado por Renne Walker, aplicado a uma maçã (E) e a um produto semipronto a base de macarrão com queijo (D). $\quad 75$

Figura 10. Representação de sete categorias de impactos de um produto no sistema $\begin{array}{ll}\text { alimentar em cinco fases. } & 76\end{array}$

Figura 11. Adaptação do modelo de movimento de significados de McCracken ao $\begin{array}{ll}\text { setor alimentar. } & 103\end{array}$

Figura 12. Modelo de rotulagem de alimentos com representação dos impactos $\begin{array}{ll}\text { sociais, ambientais, econômicos e culturais do produto. } & 128\end{array}$

Figura 13. Embalagem do Sucrilhos, frente e verso. 137

$\begin{array}{ll}\text { Figura 14. Detalhe da embalagem do Carrefour Energy Flakes. } & 138\end{array}$

$\begin{array}{ll}\text { Figura 15. Detalhe da embalagem do Nutry chocolate. } & 138\end{array}$

Figura 16. Embalagem da granola Magraça Frutazul. 140

Figura 17: Detalhes das embalagens da granola do Vivo, Pura Fibra Gaiatri, Long Life e Froot Loops. 140

$\begin{array}{ll}\text { Figura 18. Detalhes de embalagens Native. } & 142\end{array}$

Figura 19. Detalhe da embalagem de granola da Sabor Alternativo. 142

Figura 20. Verso da embalagem do Kellogg's Froot Loops. 143

Figura 21. Corn Sugar da Alca Foods e Kobby Tempestade de Neve. 143

Figura 22. Embalagem do Qualitá Ultra Flakes Açucarado com o símbolo dos $\begin{array}{ll}\text { transgênicos. } & 144\end{array}$

Figura 23. Nestlé Crunch, face frontal. No detalhe, rotulagem nutricional frontal em formato VDR. 146 
Figura 24. Metodologia indicada para determinar o tamanho da porção.

154

Figura 25. Detalhes das laterais da embalagem de Nestlé Crunch. 161

$\begin{array}{ll}\text { Figura 26. Verso da embalagem de Nestlé Crunch. } & 163\end{array}$

Figura 27. A embalagem de Nestlé Crunch no fim de 2013.

Figura 28. Face frontal da embalagem de Superbom Skarchitos. 165

Figura 29. Detalhes do verso da embalagem de Superbom Skarchitos. 167

Figura 30. Kellogg's Corn Flakes, faces frontal e lateral. 171

Figura 31. Kellogg's Corn Flakes, verso. 171

Figura 32. Granola Caseira Mãe Terra, frente e verso. 176

Figura 33. Os 7 impactos ambientais rastreados pela Mãe Terra. 183

$\begin{array}{ll}\text { Figura 34. Símbolos que convidam a reciclar a embalagem. } & 183\end{array}$

$\begin{array}{ll}\text { Figura 35. Dia Cereal Açucarado, frente e detalhe do verso. } & 184\end{array}$

$\begin{array}{lr}\text { Figura 36. Dia Muesli com frutas. } & 188\end{array}$ 


\section{INTRODUÇÃO}

A rotulagem de alimentos é o meio primário de comunicação entre o produtor ou o comerciante e o consumidor (CODEX ALIMENTARIUS, 2007). Essa comunicação tem função dupla. De um lado, é uma forma de publicidade, pois traz mensagens elogiosas ao produto e de incentivo ao consumo, seja por meio de frases, imagens, cores ou design. De outro lado, tem função informativa, pois reúne dados sobre o fabricante, a composição do produto, perfil nutricional, sua origem, datas de fabricação e validade, entre outros. Bem aproveitado, esse meio de comunicação pode ser uma ferramenta poderosa de promoção da alimentação saudável.

Mas em que medida a apresentação simultânea da informação nutricional e das mensagens da marca numa mesma embalagem pode favorecer ou atrapalhar a promoção da alimentação saudável? O equilíbrio entre a informação e a comunicação de marketing é uma questão cara à rotulagem de alimentos. Como uma interfere na outra? Há sobreposição da publicidade sobre a informação, ou o contrário? Quais significados emergem dessa simultaneidade na comunicação? Quais mensagens chamarão mais a atenção dos consumidores? Quais conceitos de alimentação saudável serão transmitidos pelos discursos proferidos pelas vozes das embalagens? Serão esses conceitos os mesmos pretendidos pelas políticas públicas, ou será que da interação entre imagens, figuras, marcas registradas e dados numéricos o que será captado pelo público será apenas um incentivo ao consumo? Estará a rotulagem obrigatória oferecendo todas as informações certas, ou dados importantes para a tomada de decisão pelo consumidor estão ausentes? E quanto à linguagem? Os rótulos, tais como foram pensados pelos legisladores, sabem se comunicar ou estão falando sozinhos?

Pairam muitas questões sobre a qualidade da rotulagem de alimentos, e nem todas elas estão sendo respondidas pela ciência, até porque nem todas as perguntas têm sido feitas com a devida frequência. 
Este trabalho tem a pretensão de provocar um olhar, ou uma escuta, um pouco mais atento sobre o potencial comunicativo dos rótulos de alimentos. Os rótulos falam, e é preciso ouvir o que eles estão dizendo para poder criticá-los e melhorá-los.

Os rótulos falam por meio das marcas. E as marcas falam muito, e em voz alta, com métodos pirotécnicos de promoção de vendas. Métodos que funcionam para seus objetivos: eles vendem porque o público escuta o que eles dizem.

Os rótulos também falam por meio das leis. $\mathrm{E}$ as leis às vezes falam pouco, em voz mais baixa que o necessário.

Alguns rótulos também falam por meio de organizações não governamentais, entidades médicas, institutos de pesquisa e empresas certificadoras que imprimem sua voz e sua credibilidade em selos que sinalizam algum tipo de cuidado.

Há menos vozes nos rótulos expostos no Brasil do que nos rótulos de produtos embalados na Europa ou nos Estados Unidos. Mas no mundo das embalagens de produtos alimentícios, de modo geral, há muitas vozes falando ao mesmo tempo, e o consumidor as está ouvindo como pode, ou como quer, ou como aprendeu a ouvir. Mas poucos são os estudos que escutam o que todas essas vozes estão dizendo.

O que essas vozes estão dizendo tem o potencial para influenciar a opinião e o comportamento dos consumidores em relação ao que é nutritivo, saudável e adequado. E, se há o risco, e há, de que elas estejam direcionando esse comportamento para o lado oposto ao pretendido pelas medidas de promoção da alimentação saudável, então será preciso fortalecer o discurso da saúde também na rotulagem e aumentar o volume da fala que tem o potencial para influenciar os comportamentos na direção certa.

E qual seria a direção certa?

Segundo a Política Nacional de Alimentação e Nutrição (PNAN), uma dieta saudável é feita de alimentos naturais, acessíveis, produzidos localmente em processos sustentáveis, sem substâncias nocivas e consumidos de acordo com os valores e costumes dos cidadãos (MS, 2012). O novo Guia Alimentar para a População Brasileira, produzido pelo Ministério da Saúde em conjunto com uma equipe de pesquisadores da Faculdade de Saúde Pública da Universidade de São Paulo (MS, 2014), é categórico em defender uma promoção da alimentação saudável com base em alimentos, que são mais do que nutrientes. 
No entanto, é de nutrientes que os rótulos falam quando falam de saúde. Não é do grau de processamento dos produtos, nem do tipo e da quantidade de agrotóxicos usados na agricultura, nem da quantidade de corantes e conservantes usados, nem dos métodos de produção agrícola, nem das distâncias percorridas entre o campo e a mesa. Por enquanto, o que a legislação prevê como parâmetro de escolha de alimentos saudáveis pelo consumidor no momento da compra é a informação nutricional obrigatória e complementar, apresentada nos rótulos numa linguagem tecnicista que contrasta com a criatividade e a liberdade das mensagens publicitárias que ocupam a maior parte das embalagens e disputam a atenção do público. Será possível promover a alimentação saudável dessa forma?

Este trabalho busca entender o que é que a rotulagem de alimentos, tal como ela é hoje, está comunicando em matéria de alimentação saudável. Mais especificamente, quais discursos estão sendo gerados por meio de seus conteúdos e linguagens. A expectativa é que, a partir dessa leitura instrumentada, que explicita os mecanismos pelos quais a comunicação por meio dos rótulos tem o potencial de mediar o consumo de alimentos, essa forma de comunicação possa ser repensada a fim de transmitir mensagens capazes de levar a consumos não apenas mais saudáveis, como também mais cidadãos.

O percurso dessa busca começa com uma exploração das bases teóricas usadas neste trabalho. $\mathrm{Na}$ introdução são apresentados primeiro os conceitos atuais de promoção da alimentação saudável. Em seguida, faz-se um apanhado da história da rotulagem dos alimentos, para que se entenda como foi que ela chegou à atual configuração. Esse tópico aborda a construção da rotulagem nutricional e algumas de suas transformações; a emergência de modelos de rotulagem nutricional frontal; a profusão de ecorrótulos em países desenvolvidos; e tentativas de experimentar formatos, linguagens e até meios novos para integrar todas as informações que vão se mostrando relevantes. O tópico seguinte apresenta as bases teórico-metodológicas para a análise empírica, trazidas dos estudos da área de comunicação, considerada aqui como fundamental para o aprimoramento da rotulagem.

O capítulo 2 apresenta os objetivos gerais e específicos da pesquisa. O capítulo 3 descreve os métodos para cada objetivo específico. Os resultados são apresentados em etapas no capítulo 4, em meio à discussão. Primeiro, uma revisão da literatura 
científica sobre rótulos de alimentos traz os resultados de estudos de recepção da rotulagem nutricional obrigatória e complementar, que analisam como o público entende e usa tal informação e mostram a fraqueza dessa rotulagem como ferramenta de promoção da alimentação saudável. Estudos sobre a rotulagem nutricional frontal indicam que os modelos experimentados até agora não funcionam. Os estudos sobre ecorrótulos revelam que ainda não existe consenso sobre o que é prioritário informar na promoção da alimentação sustentável. E alguns poucos estudos integradores trazem pistas de como estudar o potencial comunicativo das embalagens em sua totalidade, bem como sua influência sobre as práticas de consumo.

Na sequência vêm os resultados e uma primeira etapa de discussão da análise empírica do corpus, composto por seis embalagens de produtos da categoria dos "cereais matinais". Depois, é feita uma discussão mais sintética sobre as possíveis generalizações e especificidades encontradas na análise empírica. O cruzamento dos resultados da revisão bibliográfica e da análise empírica que dá origem a propostas a serem testadas em novos estudos.

$\mathrm{Na}$ conclusão, aponta-se a direção em que os estudos e a prática regulatória devem seguir a fim de tornar a rotulagem de alimentos um instrumento efetivo de promoção da alimentação saudável. 


\title{
1.1. PROMOÇÃO DA ALIMENTAÇÃO SAUDÁVEL
}

A rotulagem de alimentos é considerada uma ferramenta para a promoção da alimentação saudável, que por sua vez é um conceito derivado da promoção da saúde. Neste capítulo são apresentados os conceitos de saúde, promoção da saúde e promoção da alimentação saudável que norteiam todo o trabalho.

A Organização Mundial da Saúde define saúde como um estado de completo bem-estar físico, mental e social, e não apenas a ausência de doenças (OMS, 2005). A saúde é considerada um direito humano fundamental, garantido pela Declaração de Alma-Ata, de 1978 (MS, 2002). Esse documento afirma que a saúde deve ser a meta social mais importante, por ser essencial ao desenvolvimento dos povos, e que a promoção da saúde requer esforços dos setores sociais e econômicos, além do setor saúde.

Foi na Primeira Conferência Nacional de Saúde do Canadá, em 1981, que se introduziu a ideia de que a saúde tem o contexto social como um de seus determinantes. Embora a saúde dependa também do comportamento individual e do estilo de vida, estes passam a ser entendidos como efeitos do contexto social. A partir daí, a promoção da saúde passa a focar nos fatores sociais e ambientais. Hoje, a promoção da saúde é definida como o

\begin{abstract}
processo de capacitação da comunidade para atuar na melhoria de sua qualidade de vida e saúde, incluindo uma maior participação no controle deste processo. Para atingir um estado de completo bem-estar físico, mental e social os indivíduos e grupos devem saber identificar aspirações, satisfazer necessidades e modificar favoravelmente o meio ambiente. A saúde deve ser vista como um recurso para a vida, e não como objetivo de viver. Nesse sentido, a saúde é um conceito positivo, que enfatiza os recursos sociais e pessoais, bem como as capacidades físicas. Assim, a promoção da saúde não é responsabilidade exclusiva do setor saúde, e vai para além de um estilo de vida saudável, na direção de um bem-estar global (MS, 2002).
\end{abstract}

Paz, equidade, justiça social, renda, recursos sustentáveis, ecossistema estável, habitação, educação e alimentação são considerados igualmente fundamentais para 
haver saúde. E tudo isso tem a ver com capacidade e autonomia para gerenciar a própria saúde.

\begin{abstract}
As ações de promoção da saúde objetivam reduzir as diferenças no estado de saúde da população e assegurar oportunidades e recursos igualitários para capacitar todas as pessoas a realizar completamente seu potencial de saúde. Isto inclui uma base sólida: ambientes favoráveis, acesso à informação, a experiências e habilidades na vida, bem como oportunidades que permitam fazer escolhas por uma vida mais sadia. As pessoas não podem realizar completamente seu potencial de saúde se não forem capazes de controlar os fatores determinantes de sua saúde, o que se aplica igualmente para homens e mulheres. (...) A promoção da saúde apoia o desenvolvimento pessoal e social através da divulgação de informação, educação para a saúde e intensificação das habilidades vitais. (...) É essencial capacitar as pessoas para aprender durante toda a vida, preparando-as para as diversas fases da existência, o que inclui o enfrentamento das doenças crônicas e causas externas (MS, 2002).
\end{abstract}

Segundo a Declaração de Adelaide, de 1988, "as políticas que promovam a saúde só podem ter sucesso em ambientes que conservem os recursos naturais, mediante estratégias ecológicas de alcance global, regional e local" (MS, 2002). A conferência internacional sobre promoção da saúde daquele ano defendeu que a saúde pública e os movimentos ecológicos juntassem suas forças para o desenvolvimento socioeconômico dos limitados recursos do planeta. Em 1997, a Declaração de Jacarta pela primeira vez incluiu o setor privado no apoio à promoção da saúde e estabeleceu como prioridade promover a responsabilidade social para com a saúde.

Se a saúde é um direito e está atrelada ao gerenciamento de todos esses fatores, a alimentação saudável também deve seguir os mesmos princípios.

A partir da Declaração de Giessen, em 2005, a nutrição deixou de ser entendida como uma ciência apenas biológica, preocupada exclusivamente com as interações entre alimentos e os sistemas fisiológico, metabólico e genômico e seus efeitos sobre a saúde e a doença (BEAUMAN et al, 2005). Segundo a Declaração, a ciência da nutrição será um meio vital para manter a vida na Terra e a felicidade da humanidade no longo prazo, desde que ela se expanda e se torne uma disciplina integrativa, abrangendo outras duas dimensões além da biológica: a ambiental e a social. Assim, será útil não apenas à saúde dos indivíduos, como também à da biosfera (BEAUMAN et al, 2005). 
Essa expansão começa a partir do entendimento do conceito de sistemas alimentares, que moldam e são moldados por relações e interações biológicas, sociais e ambientais. Trata-se de saber que o modo como a comida é cultivada, processada, distribuída, vendida, preparada, cozinhada e consumida é crucial para sua natureza, sua qualidade e seus efeitos no bem-estar, na saúde, na sociedade e no meio ambiente.

\begin{abstract}
No século XX, a produção de alimentos foi transformada por maquinário pesado e química industrial, e agora talvez também seja pela biotecnologia. O processamento de alimentos, incluindo a refrigeração, permitiu o fornecimento de uma grande variedade de alimentos de um continente a outro e em todas as estações do ano. A manufatura de alimentos, o varejo e a distribuição estão agora cada vez mais concentrados em menos mãos. Cozinhas tradicionais são substituídas por novos padrões de alimentação moldados por novas tecnologias, estilos de vida e estruturas econômicas. (...) Estas afetam e continuarão afetando profundamente os alimentos e a saúde das pessoas, de populações e do planeta (BEAUMAN et al, 2005).
\end{abstract}

O Guia Alimentar para a População Brasileira (GAPB) de 2006 (MS, 2008) adota como conceito de sistema alimentar e nutricional o proposto por SOBAL et al (1998): “um conjunto de operações e processos envolvidos na transformação de matérias-primas em alimentos e de nutrientes em respostas nutricionais e que funcionam como um sistema contextualizado biofísica e socioculturalmente". Esses autores criaram um modelo integrado para explicar por quais mecanismos os sistemas alimentares são afetados e se modificam.

O modelo inclui três subsistemas (produtor, consumidor, nutrição) e nove estágios (produção, processamento, distribuição, preparação, consumo, digestão, transporte, metabolismo). O subsistema produtor enfatiza a criação de gêneros alimentícios. Envolve produção, processamento e distribuição. Produção consiste em transformar recursos de diversos ambientes em safras e commodities por meio de coleta, caça, pesca, agricultura e pecuária. Processamento é a transformação do que foi obtido na produção em alimentos ou gêneros alimentícios que as pessoas possam consumir diretamente ou preparar em suas residências. O processamento pode incluir limpeza, moagem, cocção, embalagem, separação, montagem e preservação, entre outros procedimentos. Distribuição é a transferência desses produtos até o local onde serão adquiridos no subsistema consumidor, o que inclui feiras livres, 
supermercados, sacolões, restaurantes, padarias, cantinas escolares etc. (SOBAL et al, 1998).

O subsistema consumidor foca na obtenção de alimento. Envolve aquisição, preparação e consumo. Aquisição consiste em procurar e escolher alimentos crus, processados ou preparados onde são distribuídos. A preparação é o conjunto de processos que ocorrem em uma cozinha, requerem recursos e habilidades culinárias e costumam seguir normas de determinada cultura. Consumo envolve selecionar, servir e comer alimentos, inclusive em cerimônias, celebrações, rituais e outras formas de interação social culturalmente determinadas (SOBAL et al, 1998).

O subsistema fisiológico está focado na obtenção de nutrientes e no afastamento de contaminantes. Envolve digestão, transporte (até os órgãos do corpo) e utilização (pelo organismo) de nutrientes e substâncias naturalmente presentes nos alimentos ou adicionadas por processos industriais (SOBAL et al, 1998).

O objetivo desse modelo integrado de sistema alimentar é identificar as relações entre agricultura, comida, alimentação e saúde. Uma característica fundamental desse sistema é que ele não tem começo nem fim previamente determinados. Isto é, qualquer ponto do sistema pode influenciar seu funcionamento.

Por exemplo, a produção de determinados alimentos numa dada região do planeta pode ser influenciada por favores biofísicos do ambiente, como clima, energia, qualidade do solo, disponibilidade de água potável ou biodiversidade. O aumento ou a diminuição no consumo de certos alimentos numa dada época também pode variar na medida do desenvolvimento tecnológico ou conforme a influência de outras culturas. "O pensamento sistêmico deliberadamente evita abordagens reducionistas que focam em apenas uma porção do sistema ou o enxerga de um ponto de vista de especialista" (SOBAL et al, 1998).

Considerar essas relações é relevante, entre outros motivos, porque as escolhas do consumidor interferem no sistema alimentar, e as informações direcionadas a ele podem interferir em suas escolhas.

POULIN (2006) considera o sistema alimentar também sob uma perspectiva sociológica. Cita Kurt Lewin para afirmar que, para ser consumido, o alimento 
precisa chegar até o consumidor e ser reconhecido por ele como comestível. E esse percurso entre o universo natural e a situação de consumo envolve deslocamentos e transformações realizados por atores sociais que mobilizam não apenas conhecimentos tecnológicos, como também representações (p. 252-3).

Segundo SOBAL et al (1998), falhas de comunicação entre membros de diferentes subsistemas são comuns, pois cada subsistema tem seus interesses, indicadores e linguagens particulares. "Por exemplo, nutricionistas que organizam o mundo de acordo com nutrientes ou riscos à saúde podem ter dificuldades de se relacionar com produtores que abordam questões na perspectiva das commodities ou com consumidores que partem da perspectiva do gosto" (SOBAL et al, 1998). Assim, neste trabalho, parte-se da premissa de que ajustar a comunicação com o consumidor de modo que ele entenda as influências de suas escolhas não apenas em seu corpo, mas também, de modo mais amplo, no sistema alimentar é pré-requisito na promoção da alimentação saudável e adequada.

As estruturas sociais (padrões recorrentes de interação social envolvendo pessoas, grupos e instituições) também devem ser consideradas para o entendimento de como o suprimento de alimentos e seus processos produtivos afetam e são afetados pelo modo de vida das pessoas (SCHUBERT et al, 2012). Isso porque não há apenas fazendeiros e indústrias poderosas determinando os hábitos alimentares, mas também narrativas, cotidianos domésticos e costumes familiares e locais pontuando o que é certo e o que é errado, o que é bom e o que é ruim. Para SCHUBERT et al (2012), a política alimentar e nutricional deve reconhecer a centralidade do 'social' e que "as questões que concernem a saúde e o bem-estar nutricional de indivíduos, residências, comunidades e populações ao longo de uma vida são mediadas por papéis e relacionamentos sociais, significados, atividades e organizações que mantêm a comida e as pessoas conectadas".

Há quem associe diretamente as dietas saudáveis aos sistemas sustentáveis de produção e distribuição de alimentos. LAIRON (2012) afirma que

os atuais sistemas de produção, suprimento e consumo de alimentos não atendem às necessidades humanas do presente nem do futuro, pois são incapazes de alimentar todas as pessoas de forma satisfatória e são altamente dependentes de grandes quantidades de energia, combustíveis 
fósseis, químicos, transporte de longa distância, mão-de-obra barata e perdas culturais (LAIRON, 2012).

Esses sistemas, baseados em monoculturas de commodities que alimentam as engrenagens da indústria de produtos comestíveis e de bebidas, geram emissões nocivas de gases-estufa à atmosfera e prejudicam os ecossistemas, com perda de biodiversidade, desmatamento, erosão do solo, contaminação química, escassez de água potável e outras consequências. LAIRON (2012) diz ainda que as escolhas alimentares nesse contexto são cada vez menos influenciadas pelas heranças culturais e pela integração com o meio ambiente. Dietas sustentáveis, diz o autor, seriam possíveis a partir de sistemas de produção de alimentos de primeira necessidade (como arroz e feijão, no caso brasileiro) que façam uso apropriado de novas tecnologias e necessitem de poucos recursos, ou seja, não dependam de grande número de animais, atendam a mercados locais (distribuição de curtas distâncias), requeiram pouco processamento e refinamento e dependam mais de habilidades culinárias e educação alimentar e nutricional. E tudo isso deveria ter uma forte ligação com traços positivos de culturas ancestrais.

O autor sustenta, com base em trabalhos anteriores, que sistemas de produção agroecológica apropriados, que combinem conhecimentos e práticas tradicionais com recursos modernos (também chamados de produção orgânica), podem ser 180\% mais eficientes que os sistemas agroindustriais no propósito de alimentar populações nos países em desenvolvimento (LAIRON, 2012).

Trata-se, portanto, de valorizar um tipo de conhecimento que a urbanização afastou dos consumidores não-produtores. Num sistema alimentar sustentável, o consumidor seria levado a saber que a produção local de grãos favorece a segurança alimentar e protege o país de turbulências causadas por crises internacionais; que cultivar e colher alimentos na época certa gera economia e garante melhor sabor e nutrição; que a compra de alimentos produzidos localmente reduz o uso de combustíveis poluentes no transporte de mercadorias; que a compra direta do produtor recupera a integração entre a cidade e o campo, favorece a circulação de conhecimento e facilita a negociação por preços justos; que o processamento mínimo é um dos melhores meios de manter o sabor, as substâncias benéficas e a qualidade 
natural dos alimentos, dispensando a adição de flavorizantes sintéticos, açúcar, sal, nutrientes e antioxidantes; e que, portanto, não precisamos de alimentos ultraprocessados vindos de fábricas poluentes para nos alimentar bem (LAIRON, 2012). Para o autor, dietas tradicionais saudáveis e sustentáveis são ao mesmo tempo protetoras da nutrição, da cultura, do prazer, da equidade, do bem-estar, da saúde, do meio ambiente e da biodiversidade.

É esse tipo de conhecimento que Michael Pollan, jornalista best seller e professor da Universidade da Califórnia em Berkeley, busca resgatar no livro "Em defesa da comida" (POLLAN, 2008), obra em que ele apresenta o conceito de nutricionismo. A "ideologia do nutricionismo", termo cunhado por Gyorgy Scrinis em 2002 (SCRINIS, 2002), teria convencido cientistas, políticos, empresas e consumidores de que os alimentos que a natureza produz não passam de sistemas de transferência de nutrientes, portanto bastaria extrair deles o que interessa e aplicar esses componentes em qualquer produto apetitoso para termos alimentos sintéticos perfeitos. Mas, para POLLAN (2008), que cita Scrinis, "quando a ênfase está na quantificação dos nutrientes contidos nos alimentos (ou, para ser preciso, dos nutrientes reconhecidos nos alimentos), qualquer distinção qualitativa entre alimentos naturais e processados tende a desaparecer" (p. 39).

Segundo POLLAN (2008), o nutricionismo está construído em cima de três mitos: 1) o nutriente é mais importante que o alimento; 2) como os nutrientes são difíceis de compreender, só é possível se alimentar direito contratando a consultoria de um profissional; 3) alimentar-se serve exclusivamente à saúde do corpo (POLLAN, 2008, p. 15-16). Tais mitos teriam deixado de lado tudo que a humanidade sabia sobre o ato de comer antes de "descobrir" os nutrientes, incluindo o prazer, as manifestações culturais, os rituais e todo o significado não material das refeições em grupo. E isso com base em uma ciência da nutrição que elege novos vilões e novos heróis a cada par de anos, e a cada descoberta revela que na verdade está longe de saber tudo sobre os alimentos. "Deixar os cientistas decidirem o cardápio seria um erro. Eles não sabem o suficiente" (POLLAN, 2008, p. 20).

SCRINIS (2013) diz que a história da margarina reflete algumas das maiores mudanças de paradigma ao longo das três fases da ciência da nutrição e das 
recomendações nutricionais (p. 1). Inventada por um químico francês no fim do século XIX como uma alternativa barata à manteiga de verdade, nos anos 1960 ela ganhou status de alternativa mais saudável que a manteiga, devido à diferença no perfil de gorduras dos dois produtos.

A pesquisa de Ancel Keys teria convencido a comunidade científica de que o consumo de gorduras saturadas estava associado ao risco aumentado de doença cardíaca, o que levou à conclusão imediata de que era mais saudável consumir gorduras não saturadas. Teria nascido aí a visão maniqueísta dos nutrientes que ainda rege as recomendações nutricionais: saudável é consumir nutrientes bons e evitar nutrientes ruins. "Esses especialistas consideraram os efeitos benéficos dos óleos poli-insaturados e os efeitos prejudiciais das gorduras saturadas como mais importantes que os tipos de processamento e os aditivos usados na fabricação da margarina" (SCRINIS, 2013, p.2).

A margarina é apenas o exemplo mais emblemático. Para SCRINIS (2013), a ideologia do nutricionismo moldou a pesquisa em nutrição desde o século XIX e desde então alimentou de modo crescente as recomendações alimentares, a regulação de rotulagem, a engenharia de alimentos, as práticas de marketing e o entendimento do público sobre nutrição (p. 2).

Essa redução do alimento a uma parte de seus componentes e o isolamento dessas partes como as únicas que realmente interessam teria sido o que permitiu que a indústria de alimentos pudesse chamar de alimento nutritivo qualquer produto comestível "enriquecido" com os tais nutrientes "positivos". Os supermercados passaram a comercializar nutrientes, com cada vez menos espaço para alimentos. A substituição de alimentos por produtos comestíveis com nutrientes passou a ser bem aceita, segundo POLLAN, a partir da queda de uma lei dos Estados Unidos que até 1973 obrigava a indústria a rotular como "imitação" qualquer produto alimentício que não fosse exatamente o tipo de comida tradicional "que todo mundo conhece" (POLLAN, 2008, p. 43-44).

A margarina, até então, não passava de imitação de manteiga e era vista como tal. Mas uma nova lei de rotulagem tornou a indústria livre para comercializar suas "inovações" sem chamá-las de imitações, desde que não fossem "nutricionalmente inferiores" aos alimentos naturais que estavam modificando. Claramente, foi uma 
medida extremamente positiva para a indústria, que passou a despejar imitações enriquecidas cada vez mais sofisticadas nos supermercados, com o aval da medicina e dos governos. "A adulteração fora reposicionada como ciência alimentar" (POLLAN, 2008, p. 43-45).

Anos antes, SCRINIS (2002) havia escrito que "focar tão firmemente nos componentes nutricionais dos alimentos é uma abordagem que embaça a clara distinção entre alimentos industriais e alimentos integrais e pode resultar em apoio direto ou indireto ao consumo de certos alimentos processados, como margarina". O autor colocou também que "ao reduzir os alimentos - particularmente os processados - ao nível de sua composição química e nutricional, as alegações de propriedades nutricionais [usadas nos rótulos] tendem a esconder ou desviar a atenção dos ingredientes reais, aditivos e técnicas de processamento usadas em sua produção" e que "isolar os nutrientes do contexto do alimento em que estão contidos e da dieta da qual fazem parte e afirmar que esses nutrientes isolados podem prevenir doenças ou trazer benefícios para a saúde é uma forma extremamente limitada de entender a relação entre alimentação e saúde" (SCRINIS, 2005).

Segundo MONTEIRO et al (2012a), "o processamento de alimentos é atualmente a principal força que modifica o sistema alimentar e o principal determinante da natureza das dietas e dos estados de saúde e bem-estar a elas relacionados". Os autores afirmam que o sistema em que se insere hoje a alimentação na maioria dos países de renda alta e em muitos de renda mais baixa é um novo sistema, de dimensões globais, diferente do que existia em épocas anteriores, que determina padrões alimentares a partir dos tipos de alimentos e produtos que as populações compram e consomem. Nos últimos 30 anos, esses padrões se modificaram muito rapidamente, juntamente com a prevalência de doenças, com impactos dramáticos (MONTEIRO et al, 2012a).

De acordo com a pesquisa desses autores, as últimas três décadas foram marcadas no Brasil por um aumento expressivo no consumo de alimentos que têm entre si as seguintes caraterísticas em comum: são previamente preparados e prontos para o consumo; energeticamente densos; ricos em gorduras, açúcares ou sal; e hiperpalatáveis. São essas características desses alimentos, e não o consumo isolado 
de gorduras, açúcares e sal, dizem os autores, as responsáveis pelo aumento da obesidade e doenças crônicas associadas no mesmo período. Logo, na comunicação com o consumidor voltada à promoção da alimentação saudável e da saúde, a diferenciação desses produtos - que os autores chamam de ultraprocessados merece destaque.

\begin{abstract}
Produtos ultraprocessados não são feitos de alimentos. São feitos de ingredientes. Alguns desses ingredientes são derivados de alimentos, tais como os óleos, gorduras, farinhas, amidos e açúcar, mas muitos são obtidos a partir do processamento avançado de componentes dos alimentos, como óleos hidrogenados, proteínas hidrolisadas, amidos modificados e extrudados ou restos de carnes processadas. Em termos numéricos, a grande maioria dos ingredientes dos produtos ultraprocessados são aditivos de tipos variados, que incluem conservantes; estabilizantes, emulsificantes, solventes, ligantes, formadores de volume; edulcorantes, realçadores de sabor, saborizantes e corantes. A função de muitos desses [aditivos] é dar ao produto aparência, cheiro, consistência e gosto de comida (MONTEIRO et al, 2012).
\end{abstract}

Em artigo anterior, MONTEIRO (2009) afirmava que o fator mais determinante da qualidade das dietas era o que é feito dos alimentos e seus nutrientes originais antes da compra e do consumo - ou seja, o processamento. Nesse comentário, o autor coloca a natureza, a extensão e o propósito do processamento dos alimentos, bem como o que acontece com eles como resultado, como a informação mais importante sobre o que comemos. Isso porque o ultraprocessamento indica a relevância das dimensões social, cultural, econômica, política, ambiental, comportamental, biológica e evolucionária da nutrição, bem como os aspectos evolucionários e históricos da alimentação. Nutrientes ainda são importantes, mas já não são a questão central (MONTEIRO, 2009).

Aprofundando a análise, MONTEIRO et al (2012a) identificam a atuação global de enormes corporações transnacionais de alimentos, com seu marketing agressivo e pouco regulado de produtos de marca pouco ou nada saudáveis, como a grande responsável pelo ambiente alimentar em que o consumo de produtos ultraprocessados é normalizado. Primeiro nos Estados Unidos e Reino Unido e agora em diversos países de menor renda, as refeições tradicionais, compostas por alimentos, e os sistemas alimentares tradicionais foram progressivamente substituídos por produtos prontos para o consumo, energeticamente densos, ricos em 
gorduras, açúcar ou sal, fabricados por essas corporações e vendidos no mundo todo. “Qualquer visão focada na natureza biológica da nutrição não é capaz de reproduzir o "quadro completo"” (MONTEIRO et al, 2012a). Para STUCKLER \& NESTLE (2012), os sistemas alimentares atuais não estão direcionados ao fornecimento de alimentação adequada às pessoas, mas à maximização dos lucros.

No que se refere à forma como os consumidores enxergam os produtos ultraprocessados, parte do problema recai sobre a dificuldade de classificá-los entre grupos alimentares. Após o ultraprocessamento, já não pertencem a nenhum dos grupos de alimentos conhecidos, como carnes, vegetais, frutas ou laticínios. São combinações complexas de ingredientes derivados ou imitações de alimentos desses grupos, diferentes daqueles que qualquer um armazena em casa, cuja origem não é única e muitas vezes não é revelada, e não devem ser confundidos nem entendidos como pertencentes àqueles grupos de alimentos in natura ou minimamente processados. E alguns desses ingredientes são suspeitos por não ter comprovada a segurança de consumo.

Embora contenham ingredientes derivados de carne de frango possivelmente, de partes de muitos frangos processados em conjunto -, "nuggets de frango" não deveriam ser considerados frango, nem posicionados ao lado do frango na pirâmide alimentar, nem avaliados nutricionalmente como equivalentes ao frango, pois são, por inúmeros fatores, completamente diferentes do frango (MONTEIRO et al, 2012). Não se deve, portanto, permitir que o consumidor enxergue um "frango genérico" e "nuggets de frango" como fontes de proteína animal igualmente nutritivas e saudáveis. Há distinções importantes a fazer.

A primeira distinção proposta por MONTEIRO et al (2012a) é a segregação dos produtos comestíveis num grupo à parte (grupo 3), separado dos alimentos não processados ou minimamente processados (grupo 1) e dos ingredientes culinários (grupo 2). Além de características bioquímicas distintas, os alimentos dos grupos 1, 2 e 3 também contrastam no modo de consumo. Os ultraprocessados tendem a ser fáceis de comer ou beber: muitos dispensam mesa, prato, talheres e mastigação prolongada; podem ser consumidos rapidamente, no carro, na rua, de pé ou em 
movimento, o que favorece a substituição de refeições desfrutadas em grupo por uma alimentação solitária e acelerada (MONTEIRO et al, 2012a).

MONTEIRO et al (2012b) também ressaltam que é preciso diferenciar a indústria alimentícia útil e bem-vinda daquela predatória, desterritorializada, cujo único objetivo é alcançar lucros crescentes e exorbitantes por meio principalmente da venda de produtos ultraprocessados, a despeito da sustentabilidade de economias nacionais e locais e em detrimento da saúde e do bem-estar dos cidadãos, do meio ambiente ou da soberania dos povos. Esta segunda categoria de empresas de alimentos é atualmente referida na literatura como "Big Food" ou "Big Snack", em referência a "Big Tobacco", como ficou conhecida a indústria de cigarros em razão de seu poderio contra a regulação (BROWNELL \& WARNER, 2009).

A Big Food é bilionária, conta com advogados que trabalham em seu favor contra medidas regulatórias nos países em que atua (ACHBAR et al, 2003) e, unida, soma um poder econômico equivalente ao de países de dimensões medianas (MONTEIRO et al, 2012b). Quanto mais ela cresce e aumenta suas vendas, mais ela ameaça e substitui as dietas tradicionais.

O que as pessoas deveriam saber a esse respeito é que o consumo cotidiano, regular e de grandes quantidades de produtos alimentícios ultraprocessados, vendidos sob marcas de corporações transnacionais, afeta negativamente a saúde individual, a saúde pública e o sistema alimentar. Portanto, deveria ser evitado. Esses produtos podem ser consumidos, sem prejuízo, apenas ocasionalmente e em pequenas porções, como exceções a uma dieta composta predominantemente de refeições à base de alimentos frescos do grupo 1, preparadas com ingredientes do grupo 2 (MONTEIRO et al, 2012a).

MONTEIRO et al (2012a) reconhecem que os alimentos in natura ou minimamente processados também poderiam ser divididos conforme os métodos agrícolas adotados em sua produção, como confinamento versus pasto, ou monocultura versus diversidade de culturas, ou pesca versus criação de peixes, ou controle ecológico de pragas versus abuso de agrotóxicos, ou ainda agricultura orgânica versus modificação genética, mas preferem ater-se aos três grupos de 
alimentos acima mencionados por considerar que um sistema de classificação mais elaborado seria mais difícil de operacionalizar. Não se descarta, no entanto, a relevância desses métodos na análise dos impactos do consumo no sistema alimentar.

\title{
Conceitos de alimentação saudável
}

A promoção da alimentação saudável prevê um conceito de alimentação saudável que contrasta com o nutricionismo observado na comunicação com o consumidor via rotulagem. O conceito de alimentação saudável oficial da Política Nacional de Alimentação e Nutrição é o definido pelo Conselho Nacional de Segurança Alimentar e Nutricional (Consea):

\begin{abstract}
A alimentação adequada e saudável é a realização de um direito humano básico, com a garantia ao acesso permanente e regular, de forma socialmente justa, a uma prática alimentar adequada aos aspectos biológicos e sociais dos indivíduos, de acordo com o ciclo de vida e as necessidades alimentares especiais, pautada no referencial tradicional local. Deve atender aos princípios da variedade, equilíbrio, moderação, prazer (sabor), às dimensões de gênero e etnia, e às formas de produção ambientalmente sustentáveis, livre de contaminantes físicos, químicos, biológicos e de organismos geneticamente modificados (CONSEA, 2007).
\end{abstract}

Trata-se de um conceito abrangente e interdisciplinar, que integra aspectos culturais e significados atualmente atribuídos aos termos "saudável" e "sustentável". O termo "saudável" nessa definição não se refere apenas ao sentido biológico da saúde do indivíduo, como o balanço e os efeitos dos nutrientes em seu organismo. Diz respeito ao que se come, a como se come, a onde se come, a com quem se come, a por que se come.

Essa concepção interdisciplinar da alimentação saudável já estava presente nos princípios, diretrizes e recomendações do GAPB de 2006 e foi reforçada na versão de 2014 (MS, 2008, 2014). O GAPB foi feito para servir de parâmetro para escolhas alimentares saudáveis. Segundo o documento de 2006, a promoção de escolhas alimentares saudáveis deve se dar por meio de medidas regulatórias e do 
desenvolvimento de um ambiente de consumo em que a informação seja acessível e útil no sentido de direcionar o interesse do consumidor para alimentos ao mesmo tempo saudáveis e pertencentes a sua cultura. Parte-se da premissa de que "as escolhas alimentares são determinadas (...) pelo sistema de produção e de abastecimento de alimentos." A partir disso, o raciocínio lógico proposto é que, "se esses sistemas produzem alimentos que são inadequados ou inseguros e que aumentam os riscos de doenças, eles precisam ser mudados.” (MS, 2008, p. 22).

Assim, é pressuposto da promoção da alimentação saudável ampliar e fomentar a autonomia decisória dos indivíduos e grupos, por meio do acesso à informação para a escolha e adoção de práticas alimentares (e de vida) saudáveis. Uma alternativa de ação para a alimentação saudável deve favorecer, por exemplo, o deslocamento do consumo de alimentos pouco saudáveis para alimentos mais saudáveis, respeitando a identidade cultural-alimentar das populações ou comunidades (MS, 2008, p. 23).

Há uma clara preocupação da atual política alimentar brasileira em contextualizar as práticas alimentares em seus aspectos biológicos, culturais, sociais e ambientais e afastar abordagens reducionistas, que restrinjam as dietas a seus perfis nutricionais ou bioquímicos. No GAPB de 2006, grande parte das recomendações direcionadas às pessoas de modo geral, ao setor público e aos profissionais de saúde diz respeito a aspectos não biológicos da alimentação, como a origem dos alimentos, seus modos de produção, as relações afetivas que podem existir entre as pessoas de um determinado lugar e os alimentos típicos, os modos de comer, as significações culturais dos hábitos alimentares, o prazer e as implicações ambientais da industrialização e do consumo de alimentos (MS, 2008).

\footnotetext{
Uma vez que a alimentação se dá em função do consumo de alimentos e não de nutrientes, uma alimentação saudável deve estar baseada em práticas alimentares que tenham significado social e cultural. Os alimentos têm gosto, cor, forma, aroma e textura e todos esses componentes precisam ser considerados na abordagem nutricional. Os nutrientes são importantes; contudo, os alimentos não podem ser resumidos a veículos deles, pois agregam significações culturais, comportamentais e afetivas singulares que jamais podem ser desprezadas. Portanto, o alimento como fonte de prazer e identidade cultural e familiar também é uma abordagem necessária para promoção da saúde (MS, 2008, p. 15).
}

O GAPB defende que a escolha dos alimentos deve se orientar pelos próprios alimentos como são consumidos em seu contexto sociocultural e ambiental, não pelas partes que os constituem (MS, 2008, 2014). Uma das razões para basear as 
recomendações dietéticas em alimentos, não em nutrientes, é a clareza na comunicação com o consumidor e sua capacidade de segui-las. Segundo a Organização Mundial da Saúde (OMS), as Orientações Dietéticas Baseadas em Alimentos (ODBA) contribuem para que as políticas nutricionais em cada país sejam adequadas:

\begin{abstract}
Parte dessa ação política deveria incluir a tradução das metas populacionais de ingestão de nutrientes para orientações dietéticas baseadas em alimentos (ODBA) em nível nacional. É fundamental que o Ministério da Saúde endosse ODBA que sejam consistentes e fáceis de entender. (...) ODBA deveriam ser adaptadas às necessidades específicas do país; assegurar que as necessidades nutricionais da população sejam cobertas; e contribuir com a redução do risco de doenças cardiovasculares. Além disso, deveriam estar de acordo com políticas públicas que promovam a segurança alimentar e a atividade física, um ambiente saudável e uma economia local (WHO, 2003).
\end{abstract}

WAHLQVIST \& KOURIS-BLAZOS (1999) chamam de Food Based Dietary Guidelines (OBDA) uma forma de descrever as dietas humanas que indique a maneira como os alimentos são produzidos (por exemplo, o tipo de agricultura), preparados (na culinária), processados (na indústria) e desenvolvidos (por meio de ciência e tecnologia). As ODBA, segundo os autores, apontam ainda quais são os alimentos e as receitas tradicionais e o estilo gastronômico mais importantes em cada geografia e cultura, tornando as recomendações alimentares mais práticas e fáceis de usar (WAHLQVIST \& KOURIS-BLAZOS, 1999). A prerrogativa de orientar as escolhas dietéticas da população com base nos alimentos se opõe tanto às políticas nutricionais que direcionam a atenção das pessoas para os nutrientes contidos nos alimentos quanto àquelas que separam os alimentos em grupos, como os identificados nas pirâmides alimentares.

supervalorizar ou mistificar determinados alimentos em função de suas características nutricionais ou funcionais também não deve constituir a prática da promoção da alimentação saudável. Alimentos nutricionalmente ricos devem ser valorizados e entrarão naturalmente na dieta adotada, sem que se precise mistificar uma ou mais de suas características, tendência esta muito explorada pela propaganda e publicidade de alimentos funcionais e complementos nutricionais. (...) De acordo com os princípios de uma alimentação saudável, todos os grupos de alimentos devem compor a dieta diária. (...) A diversidade dietética que fundamenta o conceito de alimentação saudável pressupõe que nenhum alimento específico ou grupo deles isoladamente é suficiente para fornecer todos os nutrientes necessários a uma boa nutrição e consequente manutenção da saúde (MS, 2008, p. 23). 
Alimentos saudáveis são, segundo o GAPB de 2006, aqueles alimentos com alta concentração de carboidratos, "como os grãos (incluindo arroz, milho e trigo), pães, massas, tubérculos (como as batatas e o inhame) e raízes (como a mandioca); as frutas, legumes e verduras; os alimentos vegetais ricos em proteínas (particularmente os cereais integrais, as leguminosas e também as sementes e castanhas)" (MS, 2008). Na versão de 2014, um dos princípios que as recomendações é que "padrões saudáveis de alimentação são possíveis apenas em sistemas alimentares que protegem e respeitam o ambiente natural de onde os alimentos são obtidos". A definição de alimentação saudável é simplificada a "uma grande variedade de alimentos preparados com quantidade reduzida de óleos, gorduras, sal e açúcar”, com concessão ao consumo ocasional de produtos prontos para consumo "para complementar e não substituir alimentos e preparações culinárias" (MS, 2014, p. 33).

Mas mudar o foco dos nutrientes para os alimentos não resolve toda a questão da promoção da alimentação saudável. AZEVEDO (2011) argumenta que a fronteira entre o alimento saudável e o de risco é tênue e sujeita a diferentes influências. Ela defende que se migre de um conceito de alimento saudável para o de alimentação saudável, considerando também os modos de produção agrícola.

Ao longo da história, os hábitos alimentares culturalmente diferenciados foram aos poucos substituídos por dietas padronizadas, definidas por parâmetros científicos e pela ótica do sistema moderno de produção de alimentos. Tal sistema dominante é baseado nos avanços tecnológicos e nas descobertas científicas da agricultura (como o uso de fertilizantes sintéticos e agrotóxicos, o melhoramento genético e a mecanização); na grande escala de produção (local e global); na industrialização; na oferta de alimentos desconectada da sazonalidade; na distribuição e comercialização em grandes redes varejistas; na escolha disponível a todos que podem arcar com os preços dos alimentos; nas desigualdades nutricionais entre as sociedades e dentro delas; e nas repercussões socioambientais vinculadas ao modelo produtivo. Mais recentemente, as biotecnologias têm sido aplicadas ao sistema agroalimentar a partir do desenvolvimento das sementes transgênicas e dos alimentos produzidos pela nanotecnologia. (AZEVEDO, 2011).

Segundo a autora, essas mudanças trouxeram dúvidas sobre como diferenciar os alimentos saudáveis daqueles que apresentam riscos. E questiona: "Como se estabelecem as relações de poder entre os diversos sistemas peritos na definição do 
que é um alimento saudável?" A resposta a essa pergunta é construída por AZEVEDO (2011) com base no que ela chama de construção social do conceito de alimento saudável, tomando como objeto de estudo o caso da soja.

A soja teria conquistado o status de alimento saudável a partir de estudos que identificaram no grão propriedades funcionais preventivas contra doenças cardiovasculares, entre outros benefícios, nos anos 1990. Mas estes contrastavam com diversos outros estudos que associavam o consumo de soja com problemas de saúde. Em meio a essas incertezas, a indústria de alimentos teria selecionado os artigos mais favoráveis à soja para transformá-la num ingrediente desejável, com mais de $60 \%$ dos produtos alimentícios vendidos em supermercados dos Estados Unidos contendo o ingrediente (AZEVEDO, 2011). As alegadas propriedades funcionais da soja também teriam levado o governo brasileiro a promover incentivos e campanhas educativas em favor do consumo do grão e seus derivados.

\footnotetext{
No Brasil, a Embrapa Soja dedica-se a ampliar o consumo humano de soja desde 1985. Inicialmente, o programa voltava-se para o melhoramento das características organolépticas da soja, com o apoio da genética e da tecnologia de alimentos. Tal ação foi seguida por um programa de educação popular e divulgação da soja que incluiu o desenvolvimento de cozinha experimental e divulgação de receitas, promoção de aulas, cursos e palestras para leigos e profissionais da saúde. Atualmente, a Embrapa Soja dispõe de assessoria de comunicação bem estruturada, que estimula a veiculação das pesquisas desenvolvidas pela empresa e insere reportagens sobre soja na mídia (AZEVEDO, 2011).
}

AZEVEDO (2011) observa que, nessa campanha que elevou a soja ao patamar de alimento funcional poderoso e saudável, não foram considerados aspectos da alimentação saudável valorizados em teoria pela política alimentar brasileira. A produção do grão gera impactos ambientais importantes, com "consequências na fertilidade do solo, na diversidade biológica da flora e da fauna, na poluição de recursos hídricos e no clima", além das implicações do uso de sementes transgênicas.

\footnotetext{
A dimensão socioeconômica também deve ser considerada na definição de riscos. Diante do atual padrão produtivo, agricultores dependem das empresas de tecnologia agrícola e causam evasão de povos nativos das áreas cultivadas e pequenos agricultores, excluídos desse processo produtivo, para eles economicamente insustentável. Segundo Relatório da Plataforma Brasileira de Direitos Humanos, Econômicos, Sociais, Culturais e Ambientais, a sojicultura também está atrelada a processos de desagregação sociocultural da população nativa das regiões de cultivo e de concentração de terras, inclusive ações de grilagem e de trabalho escravo.
} 
Embora a soja seja geradora de riquezas, os recursos provenientes da sua produção nem sempre chegam à base da pirâmide social. Estudo de Drosj mostra que a segurança alimentar e os direitos de propriedade da terra de populações menos favorecidas não melhoraram nas áreas em que a soja expandiu-se (AZEVEDO, 2011).

Seria saudável um alimento que faz mal à água, à terra e às pessoas que trabalham nela, com pouco retorno econômico e social para o País? "Considerando os conceitos de saúde ambiental e social como dimensões que formatam e ampliam o conceito de saúde humana, questiona-se quão saudável é um alimento que promove a poluição ambiental, a perda da biodiversidade e a exclusão social", coloca AZEVEDO (2011). Não há, segundo a autora, possibilidade imediata de consenso nessa questão complexa, mas é fato que um relativismo maior na classificação de determinados alimentos como saudáveis ou não saudáveis deveria permear toda comunicação sobre alimentação.

Nesse sentido, o GAPB de 2006 parece atento à complexidade da produção e distribuição de alimentos. Suas diretrizes pretendiam ser a base para a promoção de sistemas alimentares saudáveis e do consumo de alimentos saudáveis. São atributos de uma alimentação saudável, segundo o GAPB de 2006 (MS, 2008, p. 35-36):

- preços acessíveis, pois uma alimentação saudável "se baseia em alimentos in natura e produzidos regionalmente", o que favorece a geração de renda em pequenas comunidades;

- sabor, característica inerente a alimentos frescos, apesar do marketing que privilegia produtos com adição de saborizantes sintéticos;

- variedade, o que garante naturalmente a ingestão de todos os nutrientes e substâncias necessárias ao bom funcionamento do organismo, além do prazer;

- cor, que torna as refeições atrativas e também contribui para a variedade;

- harmonia, que favorece combinações benéficas entre os efeitos dos alimentos no organismo de modos diferentes de acordo com a idade e outras características individuais;

- segurança sanitária, que protege contra contaminantes e origem biológica, física e química e outros perigos. 
Entre as estratégias de promoção da alimentação saudável abordadas no GAPB de 2006 está a rotulagem de alimentos, tema que já não aparece na versão de 2014. Mas a rotulagem não está focada em alimentos, e sim em nutrientes. De modo geral, a rotulagem procura ressaltar as características dos produtos que atendem às recomendações da Organização Mundial da Saúde (WHO, 2004): limitar a ingesta de gorduras totais e saturadas, sal e açúcar adicionado; eliminar a ingesta de gordura trans; e aumentar a ingesta de frutas, hortaliças, legumes, grãos integrais e castanhas. Assim, o GAPB de 2006 sugere às famílias que escolham os alimentos mais saudáveis lendo as informações nutricionais dos rótulos (MS, 2008, p. 41).

Embora a visão integrada da alimentação saudável tenha sido enfatizada ao longo do GAPB de 2006, a abordagem da rotulagem de alimentos limitou-se à informação nutricional. A rotulagem nutricional normalmente não fornece informações adicionais que permitam ao consumidor entender de forma mais completa se tais características são suficientes ou não para considerar esses produtos como saudáveis ou como itens que podem ser consumidos com frequência, sem prejuízo ao equilíbrio da dieta. Observa-se no GAPB de 2006 uma preocupação com a leitura correta das listas de ingredientes e tabelas nutricionais pelo consumidor. Porém, não se considera a forma como essa informação é apresentada nos rótulos. Ao contrário, o GAPB de 2006 dá a entender que as recomendações dietéticas baseadas em nutrientes podem ser adequadas para a rotulagem de alimentos, o que contraria a opção pelas ODBA.

As diretrizes para a alimentação saudável, baseadas em alimentos, quando devidamente especificadas, são facilmente compreendidas por todas as pessoas. Ao contrário, as recomendações baseadas nos componentes nutricionais dos alimentos, tais como gorduras saturadas, fibras e ácido fólico, encerram mais complexidade e dificultam a compreensão, embora sejam relevantes para profissionais de saúde, sendo úteis e essenciais para o planejamento de serviços de alimentação e de nutrição para a coletividade. São também úteis para orientação dos consumidores para entendimento adequado dos rótulos dos alimentos (MS, 2008, p. 33).

Deve-se ressaltar que essa versão do GAPB de 2006 foi provavelmente redigida antes que a legislação de rotulagem nutricional entrasse em vigor e fosse testada, como se pode deduzir logo no início do capítulo "Utilizando o rótulo dos alimentos": "A partir de agosto de 2006, os produtos obrigatoriamente deverão 
conter essa informação. A informação nutricional é um instrumento fundamental de apoio à escolha de produtos mais saudáveis na hora da compra” (MS, 2008, p. 119).

É possível perceber nesse capítulo do GAPB de 2006 certo otimismo perante o papel da rotulagem nutricional como instrumento de promoção de dietas saudáveis. O texto chega a mencionar que os fabricantes de alimentos industrializados tentarão desviar a atenção dos consumidores com suas estratégias de marketing: "Naturalmente a indústria dará maior destaque às características positivas de seu produto. Dessa maneira, é importante analisar mais de uma informação” (MS, 2008, p. 119). No entanto, não fornece soluções concretas para o problema.

Cada vez mais, é importante que o consumidor tenha acesso a
informação, fortalecendo-o na capacidade de análise e decisão para optar
por um ou outro produto, frente à indiscriminada quantidade de
informações disponíveis nos diferentes veículos da mídia e publicidade. O
fortalecimento dessa capacidade de decidir pelo alimento mais adequado,
contrapondo-se às informações publicitárias e de marketing, é um desafio
a conquistar, preservando o nosso direito de consumidores (MS, 2008, p.
119).

Ao final do capítulo, o GAPB de 2006 reconhece as limitações da rotulagem nutricional e a dificuldade dos consumidores em entender sua linguagem e sugere que estes sejam ensinados a interpretar os rótulos fora do ambiente de compra.

\begin{abstract}
As informações contidas nos rótulos podem ser muito úteis na escolha de alimentos mais saudáveis; no entanto requerem um investimento em informação e educação de maneira que as informações sejam compreensíveis para os consumidores. Uma maneira de incentivar a consulta e promover a compreensão das informações é a utilização dos rótulos como material em atividades didáticas em salas de aula, centros de saúde, centros comunitários, centros de convivência. Os profissionais de saúde e da educação devem procurar oportunidades para promover grupos para essa discussão (MS, 2008, p. 124).
\end{abstract}

Nota-se assim que, apesar da preocupação do GAPB de 2006 em estimular abordagens integradas na promoção da alimentação saudável, essa visão integrada não foi estendida à rotulagem.

Na edição de 2014 do GAPB, totalmente reformulada (MS, 2014), o que restava de recomendação alimentar baseada em nutrientes foi eliminado, e não foram incluídas instruções de como ler os rótulos dos alimentos. Os conceitos defendidos por MONTEIRO et al (2012a), SCRINIS (2103) e POLLAN (2008) estão presentes na edição de 2014 do GAPB (MS, 2014). É com base nesses conceitos que se propõe 
aqui a análise da rotulagem de alimentos como instrumento de promoção da alimentação saudável.

Nesse sentido, é conveniente discutir a qualidade da informação sobre alimentação saudável usualmente destinada aos consumidores e em que medida ela está sintonizada com os objetivos da PNAN.

\begin{abstract}
Há um bocado de coisas para saber sobre o que comemos. Por exemplo, os ingredientes de um vidro de molho para espaguete, uma caixa de cereal ou uma xícara de café poderiam vir ali da esquina ou do outro lado do mundo; poderiam ser cultivados com inúmeros pesticidas ou só alguns; poderiam ser cultivados em fazendas orgânicas corporativas enormes ou em pequenas fazendas familiares convencionais; poderiam ser colhidos por crianças ou máquinas; poderiam ser estocados em armazéns higiênicos ou infestados de pestes; poderiam aumentar ou reduzir o risco de câncer. A descrição de qualquer produto alimentício poderia incluir informações sobre uma miríade de atributos (GOLAN et al, 2001).
\end{abstract}

Será que um dia os rótulos dos alimentos nos permitirão comer inteiramente conscientes de tudo o que está relacionado com o ato de se alimentar? POLLAN (2007) relata que só conseguiu alcançar essa consciência quando caçou, coletou e plantou toda a comida de uma refeição que preparou para si e amigos na Califórnia (p. 17 e 416). Foram meses de planejamento e semanas de atividades incomuns nos dias de hoje (como matar um porco selvagem e coletar cogumelos silvestres na floresta) para produzir um banquete caseiro. Ciente de quão irrealista era a proposta de alimentar-se apenas do que pudesse obter do próprio trabalho, sem gastar um centavo para comprar comida, ele levou ao extremo o conceito de slow food para descobrir as histórias que a comida era capaz de contar quando se dava a ela essa chance - histórias que os amigos que participaram da empreitada e ele mesmo puderam relatar, em primeira pessoa, reconhecendo o valor de cada etapa da transformação da natureza em refeição servida.

Para além da poesia que se pode extrair dessas histórias, a aventura de cozinhar do absoluto zero revelou que comer significa destruir vidas para manter outras. A destruição que Pollan causou, na forma de caça, pesca ou coleta (mortes), embora com um custo emocional alto para ele, teve um baixo custo a ser pago pela natureza, pois a quantidade de destruição foi pequena e tudo foi muito bem aproveitado. Para o autor, "a refeição perfeita talvez seja a que tenha sido plenamente paga, que não deixe nenhuma dívida pendente" (POLLAN, 2007, p. 433). 
Numa era em que as pessoas compram comida muito mais do que caçam, coletam e plantam, os custos da obtenção dessa comida não são os mesmos nem são pagos da mesma forma. Ao comparar sua "refeição perfeita" a uma anterior, feita com a mulher e o filho em um estabelecimento de 'comida rápida', Pollan as vê como opostas.

\begin{abstract}
Os prazeres de uma são baseados num conhecimento quase completo; os prazeres da outra, numa igualmente completa ignorância. A diversidade de uma reflete a diversidade da natureza, sobretudo a floresta; a variedade da outra reflete de maneira mais precisa a engenhosidade da indústria, especialmente sua capacidade de suscitar alguma longínqua impressão de diversidade a partir de uma única espécie criada numa única paisagem: a monocultura do milho. O custo da primeira refeição é alto, contudo é reconhecido e pago; já o preço da segunda parece uma pechincha, mas não consegue ocultar seu verdadeiro custo, acabando por cobrá-lo da natureza, da saúde e do bolso da população, e do futuro (POLLAN, 2007, p. 434).
\end{abstract}

A informação sobre os alimentos - que inclui a veiculada por meios de comunicação de massa ou privados e pela publicidade - é considerada componente do ambiente alimentar (MCKINNON et al, 2009), assim como políticas econômicas, de alimentação, de agricultura, de preços e de regulação do marketing e da publicidade de alimentos, além de ambientes de convívio como a escola, o local de trabalho, o bairro e qualquer lugar onde as pessoas encontrem comida ou comam juntas (GLANZ, 2009; MCKINNON, 2009).

O ambiente alimentar é o conjunto de fatores externos ao indivíduo que influenciam suas escolhas alimentares (BROWNELL et al, 2010). Esse ambiente pode ser promotor da saúde ou, ao contrário, contribuir para aumentar os riscos à saúde, ou ainda ter efeito neutro sobre a saúde, mas favorecer o lucro comercial (GLANZ, 2009).

Como parte do ambiente alimentar, a informação sobre os alimentos também pode influenciar positiva ou negativamente as escolhas individuais, o que em alguns casos justifica medidas regulatórias. Se é esperado que os consumidores tomem decisões acertadas na compra de alimentos, então eles precisam estar armados com informação correta, precisa e verdadeira sobre o que estão por comprar e também protegidos de informação incorreta, enganosa ou confusa (BROWNELL et al, 2010). Nesse sentido, saber o que e como informar os consumidores é uma questão de saúde pública. 
O risco de não saber exatamente o que e como informar é que, quando não existe consenso sobre isso, a tendência é que o setor privado assuma a liderança na comunicação, por meio do marketing (MACRAE et al, 2012).

\begin{abstract}
Nenhuma agência tem a responsabilidade de determinar a coerência global das mensagens direcionadas ao consumidor relativas a essas metas sociais mais amplas de saúde e sustentabilidade. Uma empresa fornece individualmente informação que mostre as maiores vantagens de consumir seus produtos, o que pode contradizer o que foi dito sobre o mesmo produto por outra empresa ou agência governamental. Consumidores sozinhos não possuem os recursos necessários para determinar com facilidade o conjunto de mensagens emitidas por uma empresa, considerando-se a dimensão dos orçamentos de publicidade da indústria. (MACRAE et al, 2012).
\end{abstract}

MACRAE et al (2012) acreditam que consumidores bem informados e engajados podem ser peças-chave na promoção de um sistema alimentar saudável e sustentável. Os autores se referem a um "movimento crescente de consumidorescidadãos, comedores que trazem para suas compras um conjunto de valores e decisões alimentares que ultrapassam os interesses individuais" (MACRAE et al, 2012). A partir dessa premissa, os autores propõem que se adotem iniciativas de curto, médio e longo prazos que deem suporte a esse engajamento e facilitem os esforços desse consumidor-cidadão.

\footnotetext{
O desafio é redesenhar os sistemas de informação ao consumidor a fim de que eles ajudem os governos a alcançar seus objetivos nutricionais, de saúde e ambientais para a população. Dadas as transformações que reduzem a autoridade do Estado sobre o sistema alimentar, os mecanismos limitados de governança e o uso reduzido de medidas efetivas, as abordagens limitadas do passado devem ser modificadas (MACRAE et al, 2012).
}

A primeira questão que MACRAE et al (2012) colocam é sobre o tipo de informação que os governos geralmente julgam necessárias para que o consumidor tome decisões racionais no momento da compra, assumindo que, para tomar decisões racionais, é preciso ter acesso a informação relevante. Na visão dos governos, dizem os autores, seria relevante informar o consumidor sobre o preço, a qualidade e a conveniência dos produtos. Mas, quando as escolhas individuais afetam o bem-estar dos demais, e esse efeito não é precificado, os consumidores podem fazer escolhas diferentes do que é ótimo para a sociedade. 
Se o preço refletisse os impactos das escolhas, aí sim o mercado seria ótimo (GOLAN et al, 2001). Mas a informação sobre os impactos sociais e ambientais da produção e da distribuição das mercadorias nem costuma ser exigida das empresas. Não se considera relevante, por exemplo, informar aos consumidores como o perfil nutricional de um produto foi afetado pelas práticas agrícolas, de armazenamento e de distribuição de alimentos adotadas (MACRAE et al, 2012), nem refletir no preço dos alimentos processados ricos em sódio e gordura saturada o custo para a saúde pública do consumo em massa desses produtos (GOLAN et al, 2001).

Segundo a teoria do mercado, a ausência de informação completa ajuda a
criar um mercado de alimentos disfuncional em que sinais parciais e
contraditórios são enviados tanto aos produtores quanto aos
consumidores. Por sua vez, esses sinais distorcidos significam que
recursos do sistema alimentar estão inapropriadamente alocados,
particularmente aqueles que ajudam a assegurar a saúde, a
sustentabilidade ambiental e o acesso igualitário (MACRAE et al, 2012).

Esse sistema de informação não apenas é incompleto para o consumidor, como também pressupõe que o setor privado não tem obrigações sociais mais amplas para além daquelas ligadas à segurança e às regras para a promoção de seus produtos. A informação assimétrica é a norma, dizem os autores. E, sem medidas regulatórias que obriguem as empresas a fornecer informações mais completas, elas dificilmente o farão de modo voluntário, a menos que isso resulte em um aumento substancial nas vendas (MACRAE et al, 2012). Sem a informação completa, o consumidor, por sua vez, poderá não saber articular o que quer.

Teria sido essa lacuna de responsabilidades que abriu espaço para que organizações não governamentais (ONGs) focadas na sustentabilidade e na saúde passassem a existir e atuar como certificadoras, vigilantes do mercado e provocadoras da consciência dos consumidores, dando origem a sistemas privados de regulação. Mudanças nos processos de produção de alimentos, como redução no uso de químicos agrícolas, tratamento humanitário de animais, preservação da biodiversidade e da vida selvagem e até práticas laborais são reclamadas pelas ONGs e transformadas em ações de responsabilidade corporativa e "marketing verde" pelo setor produtivo, que enxerga vantagens mercadológicas nessa adesão (TAVARES \& IRVING, 2009; MACRAE et al, 2012). 
Assim, informações que antes não eram consideradas relevantes passam a ser fornecidas por meio de "ecorrótulos", selos e certificações "verdes" que buscam diferenciar as empresas que declaram das que não declaram seus cuidados antiimpactos socioambientais.

Da tradicional percepção que o consumidor comum mostrava do preço, da qualidade, da segurança e da conveniência dos produtos, passa-se a uma preocupação crescente com a diversidade e a complexidade das expectativas de um consumidor mais politizado: o consumidor-cidadão.

O termo "cidadão" sugere o pertencimento a um lugar e transmite a noção de fazer parte de um estado ou nação, o que implica ter direitos e deveres perante esse lugar (WILKINS, 2005). Assim, o consumidor-cidadão não apenas compra passivamente o que está à venda, mas tem direitos, responsabilidades e poder de influência sobre o mercado. Não decide com base em seus interesses particulares apenas, mas é motivado também por questões do interesse público (MACRAE et al, 2012).

Por anos, a indústria de alimentos explicou publicamente sua ação mercadológica alegando que respondia ao desejo dos consumidores. Alimentos baratos produzidos em massa, conveniência, embalagem e ampla variedade eram explicadas como respostas aos sinais do mercado.

Pesquisas sobre o comportamento do consumidor historicamente reforçaram essa visão. Mas o mercado consumidor está menos homogêneo do que antes. Os consumidores têm se rebelado contra a produção em massa já faz algum tempo. A indústria e o varejo diversificaram a oferta na esperança de capturar esses novos segmentos de mercado. Para isso, mudaram suas estratégias promocionais e investiram em instrumentos sofisticados de pesquisa. Alguns consumidores, uma vez a par das novas opções, responderam com mudanças no comportamento de compra. Todos esses desenvolvimentos confirmam as interconexões interativas e dinâmicas entre a disponibilidade do produto, a informação ao consumidor e seus desejos. Está cada vez mais claro que as demandas do consumidor são frutos de necessidades individuais e coletivas, do acesso e disponibilidade, do tipo de informação e da forma como esta é oferecida (MACRAE et al, 2012).

O discurso do consumo ético parte da ideia de que consumir é uma forma de gerar mudanças sociais (JOHNSTON, 2007). Em suma, espera-se do consumidorcidadão de alimentos que ele coma de modo responsável. Essa forma de atuação política é considerada autônoma, não institucionalizada ou fomentada por movimentos sociais, sustentada no pressuposto de que "o microcosmo das condutas 
pessoais se inter-relaciona com o macrocosmo dos problemas globais" (PORTILHO et al, 2011). O consumo politizado seria uma consequência das novas configurações sociais, como a perda de tradições, da proteção de instituições centralizadoras e do contato com a natureza para culturas de consumo globalizadas, num processo de transição das velhas formas de atuação política (institucionalizadas) para as novas, centradas na vida privada.

\begin{abstract}
novas preocupações se juntariam às políticas emancipatórias tradicionais, dando origem às políticas de vida, que apontam para um padrão de engajamento relacionado às lutas sobre como queremos viver, como indivíduos e como humanidade, num mundo que era determinado pela tradição e pela natureza e que agora se encontra, cada vez mais, submetido às decisões humanas. (PORTILHO et al, 2011).
\end{abstract}

Comer é um ato político porque o acesso ao alimento é indissociável de relações de poder. Os consumidores de alimentos produzidos em processos globalizados estão à mercê de práticas empresariais, normas regulatórias, políticas e recursos muitas vezes decididos em um lugar milhares de quilômetros distante do local onde compram a comida. E essa submissão às cegas significa risco, daí o sentimento de que interferir é preciso.

Quando se trata de produtos locais, a alimentação é uma decisão política na medida em que cada alimento tem uma história com implicações complexas que merecem ser consideradas. Nesse sentido, a distância entre o que sabemos sobre os alimentos e o que poderíamos saber faz toda a diferença - e suscita questões sobre o que, afinal, julgamos importante saber (a escolha dos riscos que mais nos preocupam) (PORTILHO et al, 2011). O acesso à informação completa sobre o que se come torna-se assim um direito mais valorizado.

Uma das mais antigas formas de tentar interferir no social por meio do consumo é o boicote, tipo de punição que teria sido inaugurado no século XIX (JOHNSTON, 2007, p. 236). Mais recentemente, ele tomou a forma de buycott [neologismo que combina boycott (boicote) com buy (comprar)], que seria a substituição de uma marca por outra na preferência de compra com base em alegações sobre os produtos. E o que torna o buycott possível é a rotulagem regulada por governos ou terceiros, que legitima e controla as mensagens do marketing e ajuda os consumidores a identificar os produtos alinhados com seus valores e 
preocupações (MACRAE et al, 2012). O objetivo final do buycott é que a demanda por produtos “do bem” cresça a ponto de aumentar a oferta (HOLZER, 2006).

Mas que tipo de sistema de informação nos rótulos será capaz de alavancar o fenômeno do consumo cidadão e avançar nos objetivos dos governos no campo da saúde e da sustentabilidade? Para MACRAE et al (2012), o Estado deve antecipar as mudanças na demanda em vez de esperar que ela aconteça espontaneamente. Isso significaria facilitar o entendimento do público e moldar o comportamento individual para alcançar objetivos coletivos, o que poderia ser melhor do que regular o mercado diretamente (MACRAE et al, 2012).

Os autores procuraram identificar quais mudanças nos sistemas de informação podem apoiar escolhas alimentares saudáveis e sustentáveis e formularam algumas propostas, tais como: a) mudar a rotulagem para sistemas mais completos, simples e integrados, que incluam informação sobre os processos produtivos e seus impactos socioambientais, bem como a presença de contaminantes; b) rotular de alimentos que atualmente não são completamente rotulados, como frutas e hortaliças; c) associar a rotulagem nutricional com as recomendações alimentares baseadas em alimentos; d) declarar a quantidade de aditivos usada; e) estender para o varejo a veiculação de informação sobre os alimentos e mensagens de saúde (MACRAE et al, 2012). Na visão dos autores, a informação completa e clara, combinada com outras mudanças no ambiente alimentar, tornaria os consumidores empoderados para modificar o sistema alimentar no sentido mais favorável à saúde pública e à sustentabilidade.

Isso se, além de informação completa e confiável, o consumidor tiver a seu favor uma educação suficiente, tempo e energia para ler rótulos e considerar todos os riscos socioambientais de suas escolhas no momento da compra, tendo o desejo real de restringir suas escolhas em nome de um sistema alimentar mais sustentável e socialmente justo (JOHNSTON, 2007, p. 254). E há ainda a questão de como garantir que o lado cidadão desse consumidor não seja manipulado pelo marketing e tornado mais um joguete do consumo do que atitude e ação cidadã.

JOHNSTON (2007) questiona se consumir produtos divulgados como mais sustentáveis seria de fato uma maneira de melhorar o mundo. O autor lembra que a 
transferência de responsabilidades sobre as causas sociais e ambientais para os consumidores ocorreu na medida em que os Estados nacionais recuaram na função regulatória e na manutenção do bem-estar social e abriram mais espaço para que as corporações se autorregulassem (JOHNSTON, 2007, p. 246)

Em tese, nesse cenário neoliberal, os consumidores-cidadãos assumiriam a função de regular o mercado. Mas, para o autor, o conceito de consumidor-cidadão é contraditório. Como consumidoras, as pessoas estariam interessadas em possuir e usar bens de consumo, entendendo o direito de escolha como a condição social ótima e o maior usufruto da liberdade. O consumo responde, portanto, ao interesse individual, ao desejo de status e aos ideais de ascensão social (JOHNSTON, 2007, p. 242). Como cidadãs, por outro lado, as pessoas estariam interessadas no bem comum e no acesso igualitário aos recursos essenciais à vida e agiriam dispostas a sobrepor os objetivos coletivos aos individuais, gozando do prazer de contribuir pelo benefício geral.

Outra contradição entre o consumismo e a cidadania identificada por JOHNSTON (2007) é que aquele procura conservar a natureza por meio do consumo de mais produtos "verdes", ao passo que a forma cidadã de resolver a questão ambiental seria a redução no consumo. "Embora a cidadania não exija eliminar a escolha do consumidor, ela exige que a escolha do consumidor perca sua posição centralizada e suprema de ditar valores" (p. 250).

Ainda que sem descartar inteiramente a possibilidade de esses dois papeis coexistirem, JOHNSTON (2007) coloca que, se deixarmos as corporações liderarem o engajamento dos consumidores-cidadãos, a valorização das escolhas individuais continuará sendo exacerbada em detrimento da cidadania.

Por mais contraditório que possa parecer, é comum que marcas de fast-food e bebidas adoçadas digam trabalhar em prol das escolhas mais saudáveis e sustentáveis pelo consumidor (LUDWIG \& NESTLE, 2008). Por meio de mensagens de marketing, versões modificadas de seus produtos mais populares e relatórios corporativos (LIMA, 2012), membros da Big Food comunicam ao mercado que também estão preocupados com a obesidade e os problemas ambientais e, mais do 
que isso, podem ajudar a solucionar esses problemas, parecendo esquecer que o coração de seu negócio - vender produtos ultraprocessados, hiperpalatáveis, hipercalóricos e insustentáveis em porções enormes - tem como "efeito colateral" causar esses mesmos problemas.

A literatura mostra que tais corporações frequentemente mentem, associam-se a governos por meio de parcerias público-privadas que beneficiam mais a si mesmas que aos interesses públicos, financiam pesquisas científicas favoráveis a seus produtos e investem pesadamente em lobby contra medidas regulatórias que limitariam o alcance de suas ações de marketing e minimizariam os danos que causam (LUDWIG \& NESTLE, 2008; BROWNELL \& WARNER, 2009; ROBIN, 2008).

\begin{abstract}
Essas empresas podem deixar uma pegada de saúde ${ }^{a}$ melhor no mundo de diversas maneiras (reformulando seus produtos, vendendo alimentos menos calóricos e opções mais saudáveis, limitando o marketing direcionado às crianças e se retirando das escolas). A questão é se elas irão se comportar de forma honrada, promovendo a saúde, ou se rebaixar ao nível da indústria do tabaco (BROWNELL \& WARNER, 2009).
\end{abstract}

Acontece de as mesmas empresas possuírem portfólios de produtos tão variados que incluam tanto alimentos considerados saudáveis quando junk food insuspeita (BROWNELL \& WARNER, 2009), o que pode torná-las ao mesmo tempo bem-vindas e indesejadas. O fato é que as largas margens de lucro na Big Food vêm dos produtos altamente processados. "Ainda que as companhias de fastfood possam oferecer itens mais saudáveis, a maior parte de seus lucros provém de batatas fritas e refrigerantes, o que explica por que as frutas raramente aparecem em suas propagandas" (LUDWIG \& NESTLE, 2008).

LUDWIG \& NESTLE (2008) sintetizam da seguinte forma as duas únicas possíveis atribuições da Big Food: ou ela procura aumentar seus lucros convencendo os consumidores a consumir mais (o que os leva a engordar) ou aumenta suas margens de lucro lançando versões de produtos com maior teor de marketing (geralmente, ainda mais processados). De um modo ou de outro, o objetivo será

\footnotetext{
a Tradução literal de "health footprint". O termo "pegada", no sentido de legado, tem sido usado para indicar impactos negativos. "Pegada ecológica", por exemplo, indica o impacto ambiental causado por determinada pessoa, empresa, setor ou grupo.
} 
sempre aumentar os lucros, não melhorar a alimentação ou a consciência política do público. E não seria possível alcançar essa meta vendendo alimentos menos processados e mais saudáveis, pois estes são bastante menos lucrativos. Ou seja, encampar integralmente as mensagens da saúde pública - 'coma menos'; 'prefira alimentos frescos'; 'opte por porções menores' - significaria trabalhar contra seu próprio negócio.

Reportagem da revista The Economist destaca que o aparente esforço das empresas em oferecer produtos mais saudáveis esbarra ainda na inexistência de conceitos consensuais de alimento saudável e junk food. A revista exemplifica: "Uma cenoura é claramente saudável e uma bebida adoçada não é, mas a distinção entre elas nem sempre é tão óbvia” (THE ECONOMIST, 2012). Essa falta de um parâmetro único dificultaria a medição dos reais avanços da indústria em direção à saúde. Nesse contexto de pouca clareza, abrem-se as brechas para que qualquer sinal de ação positiva mínima possa ser divulgado como o tipo de transformação efetiva de que o mundo precisa, mas que geralmente não acontece.

\footnotetext{
Garantias mais específicas estão sendo oferecidas em países ricos, onde as taxas de obesidade são mais altas e o escrutínio, mais minucioso. $\mathrm{Na}$ Inglaterra, 21 empresas atacaram um "Acordo de Responsabilidade" com o Ministério da Saúde segundo o qual elas deveriam se comprometer a ajudar as pessoas a consumir menos calorias. Nos Estados Unidos, o maior e mais inspecionado mercado, 16 empresas prometeram cortar 1,5 trilhão de calorias de seus produtos até 2015 (quantidade baseada num cálculo aproximado de quantas calorias o americano médio deveria cortar de sua dieta para ser saudável). E virtualmente todas as empresas têm seu próprio plano para melhorar a nutrição, alguns mais robustos que outros (THE ECONOMIST, 2012).
}

As empresas que se veem impelidas a atender a essa demanda por atitudes responsáveis não só "repaginam" seus produtos e se dirigem ao consumidor com apelos à saúde e à sustentabilidade, como também apresentam suas supostas boas ações em relatórios corporativos destinados ao escrutínio do mercado particularmente o financeiro. Corporações incluem em seus relatórios declarações sobre reciclagem de embalagens, marketing direcionado às crianças e reformulação de produtos como forma de se apresentar de forma positiva, mas tais ações ainda são consideradas insuficientes como medidas de melhoramento do sistema alimentar 
(LIMA, 2012), talvez porque os relatórios não respondem as perguntas mais pertinentes.

A criação de novos modelos de relatórios e indicadores para avaliar o impacto das atividades do setor de alimentos e bebidas sinaliza o interesse do mercado em agregar valor para as marcas engajadas na causa da nutrição, mas ainda carece de critérios adequados para distinguir o tipo de engajamento de que a sociedade precisa (ATNI, 2012; LIMA, 2012).

As ações de responsabilidade corporativa anunciadas pela Big Food são alvos de críticas também por serem tão falsas quanto as da Big Tobacco (BROWNELL \& WARNER, 2009). As empresas de alimentos também usam ações vistas pelo público como benéficas à sociedade, por exemplo o patrocínio ao esporte ou a hospitais ou projetos filantrópicos, como formas de desviar a atenção pública de suas reais responsabilidades.

Também é característico de suas campanhas depositar a responsabilidade pela qualidade da alimentação nos ombros do consumidor, dando ênfase ao poder de escolha. Ao destacar a importância de o consumidor fazer escolhas saudáveis em vez da participação das empresas na criação de um ambiente não saudável, as campanhas de responsabilidade corporativa da indústria de refrigerantes, assim como as da indústria do tabaco, valorizam a responsabilidade individual, não a corporativa (DORFMAN et al, 2012).

Com essas táticas, dizem ao mundo que estão fazendo sua parte e afastam - ou adiam - qualquer intenção dos governos ou da sociedade de lhes tolher a liberdade de seguir vendendo mercadoria lucrativa. E assim melhoram sua imagem pública sem mexer no seu negócio central (DORFMAN et al, 2012).

Como fazer escolhas informadas nesse contexto? Deve o consumidor julgar sozinho essas empresas, seus produtos e modos de operar a fim de fazer suas escolhas para o bem do sistema alimentar - ou alguém com mais autoridade deve fazer esse julgamento antes? Com base em quais informações e métodos de verificação deveria ser feito tal julgamento? 
Por enquanto, essa verificação não pode ser feita de uma só vez, a partir de uma única fonte de informação. Os impactos da produção, distribuição e consumo de cada produto comestível e bebida industrializada na saúde e no sistema alimentar não estão todos medidos e declarados abertamente de modo que o consumidor possa consultar essa informação antes da compra ou da refeição. Alguns estão indicados em rótulos, outros em sites de organizações ambientalistas ou defesa do consumidor, muitos aparecem em artigos científicos, outros tantos em reportagens, livros, documentários, blogs. Pouco é revelado nos sites das empresas e seus relatórios corporativos.

Se existe a intenção de que os consumidores façam escolhas mais informadas e saudáveis, é prudente que toda essa informação difusa sobre a atuação das empresas e as características de seus produtos seja checada, reunida, sintetizada e apresentada com transparência e clareza antes do momento decisivo.

JOHNSTON (2007) fez um estudo de caso da rede de supermercados americana Whole Foods Market (WFM) - focada em convencer o freguês de que comprar ali significa fazer o melhor pelo planeta, pois seus produtos seriam naturais, não transgênicos, locais e protetores da biodiversidade. Ele observou que o consumismo, na forma de opções numerosas de produtos vindos de diversas partes do mundo, era desproporcionalmente mais valorizado nas lojas do que as escolhas pautadas no bem coletivo. Assim, ainda que a rede forneça - nos pontos de venda, em rótulos mais abundantes do que em outros supermercados, em folhetos e no site da marca - informação sobre as questões socioambientais envolvidas na produção de alimentos, essa informação não seria suficiente para equilibrar os papéis de consumidor e cidadão de seus fregueses.

\footnotetext{
Enquanto a WFM oferece informação que encoraja a consciência das responsabilidades cidadãs, e essa informação é impressionante quando comparada a supermercados convencionais, ela claramente deixa a desejar nos ideais de equilíbrio entre consumo e cidadania. WFM deliberadamente vende commodities industriais convencionais para dar 'escolha' aos consumidores, mas nem sempre esclarece quais rótulos se aplicam a quais produtos (JOHNSTON, 2007, p. 253).
}

Estendendo a análise para a atuação de outras empresas como facilitadoras do consumo cidadão, JOHNSTON (2007) indica que as grandes corporações não são o 
guia mais confiável para as escolhas mais politizadas. "É improvável que uma corporação legalmente constituída para maximizar o retorno financeiro de seus acionistas oriente a experiência do consumo ético em torno das obrigações da cidadania” (p. 260). Ao contrário, argumenta, as iniciativas das grandes empresas nesse sentido representam a privatização das preocupações socioambientais.

Um mercado de alimentos efetivamente mais propício ao consumo-cidadão seria aquele formatado por organizações sem fins lucrativos, mais capazes de descentralizar a noção de escolha individual a serviço de ideais como justiça social, solidariedade e sustentabilidade (JOHNSTON, 2007, p. 262-263).

Ainda que o mercado esteja atento a tudo isso, o "sucesso" do consumo cidadão dependerá ainda do poder que os consumidores sejam capazes de exercer sobre o mercado por meio de suas escolhas (HOLZER, 2006). Esse poder seria limitado primeiramente pela "relação secundária" que podem estabelecer com o que compram: os consumidores não decidem diretamente o que será produzido e ofertado; só podem escolher o que comprar (ou não comprar) dentre as opções que produtores e comerciantes decidiram vender. O poder máximo que podem alcançar é, assim, a melhor escolha possível a partir do que foi decidido por outrem.

Outra limitação do poder do consumidor é que sua única arma é o dinheiro, e o dinheiro não é capaz de punir diretamente (HOLZER, 2006), a menos que uma grande massa de consumidores pratique simultaneamente um boicote. Além disso, o dinheiro é em si um limite às decisões de compra, o que tende a impossibilitar que se faça política pura no supermercado. Para HOLZER (2006), o consumidor sozinho tem chances mínimas de mudar alguma coisa por meio da compra, mas pode maximizar seu poder unindo-se a outros consumidores em torno de uma mesma causa, o que transforma escolhas individuais em ações coletivas.

É nesse aspecto que os movimentos sociais e as ONGs têm um papel fundamental na politização do consumo. São eles que identificam as causas pertinentes, estudam possíveis soluções e maneiras de alcançá-las e mobilizam indivíduos e suas carteiras em direção a uma ação consistente, capaz de tornar 
visíveis os desejos de parcela do mercado consumidor e assim interferir na oferta (O'ROURKE, 2005; HOLZER, 2006).

Como vemos, a promoção da alimentação saudável como quer a PNAN é tarefa complexa, que deve envolver esforços interdisciplinares e métodos de comunicação integrados. O próximo capítulo traça um histórico da rotulagem de alimentos. O propósito dessa retomada histórica é entender a lógica da construção do modelo de rotulagem atualmente adotado no Brasil para que possamos analisá-la criticamente e elaborar propostas de atualização do modelo, à luz dos novos conhecimentos. 


\subsection{ROTULAGEM DE ALIMENTOS: UM PANORAMA}

A informação nutricional nos rótulos começou a aparecer nos Estados Unidos nos anos 1970. Naquele momento, lá, como no Brasil, a preocupação maior da saúde pública era o aporte de nutrientes na alimentação, não o excesso de peso ou as doenças crônicas. O propósito era ajudar os consumidores a identificar os alimentos que mais se encaixassem no conceito de dieta saudável de então por meio da comparação do conteúdo de nutrientes com as recomendações nutricionais, bem como entre produtos (TAYLOR \& WILKENING, 2008a).

Desde 1973, era necessário rotular apenas produtos enriquecidos ou com alegações de propriedades nutricionais na embalagem. E não havia exigências quanto à forma das informações nem à contextualização do consumo do alimento em relação à alimentação diária (KESSLER et al, 2003).

Em 1990 o congresso americano aprovou o Nutrition Labeling and Education Act (NLEA), uma lei que designava o Food and Drug Administration (FDA) como responsável por medidas de educação nutricional para a população. Entre outras medidas, a lei criou a tabela nutricional obrigatória, que deveria apresentar as quantidades relativas de nutrientes em gramas e seus respectivos percentuais em relação às necessidades nutricionais diárias nas embalagens de todos os produtos regulados pelo órgão (lá, como aqui, o Departamento de Agricultura é responsável pela rotulagem de parte dos alimentos). O objetivo era ajudar a população a reduzir o risco de adquirir doenças associadas à alimentação (KESSLER et al, 2003; TAYLOR \& WILKENING, 2008a).

A decisão sobre quais informações colocar na tabela nutricional procurou priorizar os nutrientes e substâncias de maior importância para a saúde pública e que ajudassem o público a seguir as recomendações 
dietéticas gerais para a população. $O$ foco não estava nas necessidades de saúde específicas de determinados grupos. Na visão do FDA, a rotulagem nutricional deveria abordar simultaneamente os nutrientes associados com a etiologia de doenças crônicas e deficiências nutricionais, ou seja: calorias, calorias derivadas de gordura total, gordura total, gordura saturada, colesterol, sódio, carboidratos totais, carboidratos complexos, açúcares, fibras, proteína total, vitaminas, minerais e outros nutrientes considerados apropriados, e tudo isso no contexto de uma alimentação diária (KESSLER et al, 2003; TAYLOR \& WILKENING, 2008a).

Um ponto controverso era a declaração discriminada de açúcares adicionados. No processo decisório, houve quem argumentasse não haver evidência de que açúcares adicionados e açúcares naturalmente presentes nos alimentos agissem no corpo de forma diferente. E não havia métodos analíticos para distinguir açúcares adicionados dos de ocorrência natural. Sem isso, o FDA não foi capaz de incluir essa exigência. Assim, os rótulos deveriam declarar o total de açúcares, definido como a soma de todos os monossacarídeos e dissacarídeos livres (TAYLOR \& WILKENING, 2008a).

A ordem dos nutrientes na tabela era um fator importante, pois refletiria as preocupações nutricionais prioritárias. $\mathrm{Na}$ época a gordura era a principal preocupação. A ordem proposta pelo FDA era: calorias, gorduras, outros macronutrientes, vitaminas e minerais obrigatórios, como o cálcio. A tabela deveria ser o mais fácil de entender possível, de modo que o consumidor rapidamente captasse o significado dos números no contexto da sua dieta. Era importante que o público conseguisse distinguir se os nutrientes estavam presentes em quantidades pequenas ou grandes em relação a uma dieta ideal. À época, os americanos se confundiam com as quantidades absolutas em gramas (não percebiam, por exemplo, que $2 \mathrm{~g}$ era $>200 \mathrm{mg}$ ). Assim, o uso de percentuais foi considerado a melhor estratégia, até porque facilitaria a comparação entre produtos (TAYLOR \& WILKENING, 2008a).

O uso de negrito para destacar as informações mais importantes foi um dos recursos escolhidos para guiar a leitura da tabela. E a apresentação das 
informações nutricionais dentro de um quadro destacado das demais informações na embalagem foi considerada competitiva em relação a outros elementos comunicativos que chamavam a atenção dos consumidores, incluindo idosos e pessoas com limitações visuais (TAYLOR \& WILKENING, 2008a). O projeto gráfico da tabela foi elogiado entre designers e ganhou 0 Prêmio Presidencial de Excelência em Design. Embora tivesse suas imperfeições, na comparação com outros formatos testados, a tabela foi a mais eficaz como ferramenta para os consumidores compararem produtos alimentícios, avaliarem a veracidade das alegações nutricionais, contextualizarem o consumo do produto na alimentação diária, usarem o conceito de valores diários recomendados e avaliarem quão saudável era o alimento (KESSLER et al, 2003).

A escolha das informações obrigatórias deveu-se também à necessidade de fazer caber a informação no espaço limitado das embalagens, o que desde sempre foi um desafio. Era preciso priorizar o que fosse essencial e deixar de fora o que não faria tanta falta, até para evitar que o excesso de informação confundisse os consumidores. E seria na informação obrigatória que se baseariam as alegações de saúde e propriedades nutricionais (TAYLOR \& WILKENING, 2008a).

Apesar de todo esse cuidado e da intenção do congresso americano de que o NLEA fosse um marco pela educação, há evidências de que a mera inclusão da tabela nutricional nas embalagens não garante escolhas nutricionais mais saudáveis (TAYLOR \& WILKENING, 2008a). A necessidade de rever o modelo de rotulagem nutricional foi reconhecida não muito depois de sua criação, em virtude do crescimento, não redução, da epidemia de obesidade (KESSLER et al, 2003).

E a ainda há o papel dos health claims e dos nutrient content claims. Até a aprovação do NLEA, as alegações de propriedades nutricionais estavam pouco reguladas e as de efeitos sobre a saúde eram proibidas em embalagens de alimentos. Mas uma jogada de marketing da Kellogg, a empresa de "cereais matinais", abriu alas para o fortalecimento do marketing 
nutricional nas embalagens (NESTLE, 2003, p. 240). Em 1984, as embalagens da linha Kellogg's All-Bran nos EUA passaram por cima da regulamentação e da autoridade do FDA e incluíram o seguinte texto:

\begin{abstract}
O Instituto Nacional do Câncer acredita que comer os alimentos certos pode reduzir seu risco de ter câncer. Estas são as recomendações: Coma alimentos ricos em fibras. Um crescente corpo de evidências mostra que alimentos ricos em fibras são importantes para uma boa saúde. É por isso que uma dieta saudável inclui alimentos ricos em fibras como cereais com farelo (NESTLE, 2003, p. 240).
\end{abstract}

Segundo NESTLE (2003), a posição do FDA era inconsistente com a ideologia desregulatória da gestão do presidente Ronald Reagan. Outro órgão do governo, o Federal Trade Comission (FTC), apoiava as alegações de propriedades de saúde nas embalagens de alimentos, e a Kellogg as defendia como um serviço de utilidade pública - um serviço que resultou num aumento de $47 \%$ nas vendas de All-Bran em seis meses. $O$ resto da indústria de alimentos rapidamente entendeu que alegações de saúde ajudariam a vender seus produtos (p. 241-2).

Em 1989 cerca de 40\% dos produtos alimentícios eram rotulados com algum tipo de mensagem de saúde (NESTLE, 2003, p. 245). Com a nova legislação, as condições para usar alegações de saúde nos rótulos incluíam evidência científica publicada, com base em estudos de qualidade, conduzidos de acordo com procedimentos científicos-padrão, avaliados e aprovados por especialistas qualificados. Mas o termo healthy podia ser usado sem muitas restrições. Bastava que o produto tivesse baixo teor de gorduras totais e saturadas, quantidade moderada de colesterol e sódio e pelo menos $10 \%$ das quantidades recomendadas das vitaminas $\mathrm{A}$ e $\mathrm{C}$, ferro, cálcio, proteína ou fibras. Mas, para que os fabricantes não fortificassem seus produtos apenas para alcançar essas condições, ficou proibida a fortificação somente para fins de rotulagem (NESTLE, 2003, p. 256).

Relatórios do FDA sobre os efeitos dos health claims sobre o consumo mostraram que os consumidores acreditavam erroneamente que os produtos que os exibissem na embalagem tinham maior chance de trazer 
determinados benefícios à saúde e que a presença de alegações de saúde reduzia a chance de os consumidores lerem as demais informações nutricionais da embalagem (NESTLE, 2003, p. 287). Mas, décadas e muitos estudos depois, as alegações permanecem nos rótulos até hoje.

TAYLOR \& WILKENING $(2008 a, b)$ pontuam que o NLEA tinha um E em sua proposta: o $E$ de educação. $O$ pressuposto era que a rotulagem nutricional dependia da educação do público para ser bem-sucedida, pois só poderia ser usada corretamente mediante determinadas habilidades de leitura e interpretação. Nos artigos de 2008 aqui citados, os autores colocam a rotulagem nutricional como um trabalho ainda em desenvolvimento e apontam a necessidade de ampliar a pesquisa sobre como o público entende e usa os rótulos. Pesquisas desse tipo serão apresentadas na revisão bibliográfica no capítulo de resultados.

No Brasil, a legislação de rotulagem nutricional começa a se formar no fim dos anos 1990. Até então existia a Resolução Normativa nº 12, de 1978 , criada pela Câmara Técnica de Alimentos, que estabeleceu padrões para rótulos de alimentos embalados, definindo como as informações deveriam ser distribuídas pela superfície da embalagem: nome do produto, marca, conteúdo e declaração específica no painel frontal; relação de ingredientes, aditivos intencionais e nome do país de origem nos painéis laterais. Em 1998, essa resolução foi substituída pela Portaria no 42 da Secretaria de Vigilância Sanitária do Ministério da Saúde (SVS/MS), que tornou obrigatória a identificação do lote, do prazo de validade e de instruções sobre o preparo e uso dos alimentos, quando necessário, e proibiu alegações de propriedades que os alimentos não possuíssem (FERREIRA \& LANFERMARQUEZ, 2007).

Também de 1998, a Portaria $n^{\circ} 41$ da SVS/MS inaugurou a legislação referente à rotulagem nutricional obrigatória para alimentos embalados com alegação de propriedade nutricional (informação nutricional complementar). Nestes casos, tornou-se obrigatório declarar o valor energético, os teores de proteínas, carboidratos, lipídios e fibra alimentar presentes a cada $100 \mathrm{~g}$ ou 
$100 \mathrm{~mL}$ de produto. Não era obrigatório declarar o conteúdo de vitaminas. Do mesmo ano, a Portaria $n^{\circ} 27$ da SVS/MS regulamentou a inclusão da informação nutricional complementar nos rótulos, caracterizada por alegações como baixo conteúdo", "fonte", "alto teor", "reduzido", "aumentado", etc. (FERREIRA \& LANFER-MARQUEZ, 2007). Hoje o documento que regula essas alegações é a Resolução da Diretoria Colegiada (RDC) $n^{\circ} 54$, de 2012. Ainda em 1998 foram estabelecidos pela primeira vez os valores de Ingestão Diária Recomendada (IDR), (Portaria ${ }^{\circ}$ 33 SVS/MS), atualizados em setembro de 2005 na RDC nº 269.

Em 1999 foi criada a Agência Nacional de Vigilância Sanitária (Anvisa), vinculada ao Ministério da Saúde e de responsabilidade de uma diretoria colegiada, que passou a assumir parte da legislação de rotulagem de alimentos. A partir daí, toda a regulamentação de responsabilidade da Anvisa passou a ser divulgada por meio de Resoluções da Diretoria Colegiada. Nesse ano, o Ministério da Saúde instituía a Política Nacional de Alimentação e Nutrição (PNAN), que tinha como uma de suas prioridades a prevenção da deficiência de micronutrientes como vitamina $A$, ferro e iodo (FERREIRA \& LANFER-MARQUEZ, 2007).

Em 2000, a RDC $\mathrm{n}^{\circ} 94$ revogou a Portaria $\mathrm{n}^{\circ} 41$ e tornou a rotulagem nutricional obrigatória para todos os alimentos e bebidas embalados, incluindo a declaração de gorduras saturadas, colesterol, cálcio, ferro e sódio, tudo com base na porção sugerida e a cada $100 \mathrm{~g}$ ou $100 \mathrm{~mL}$ de produto. Mas as porções sugeridas só foram regulamentadas em 2001 (RDC n 39), com base pirâmide alimentar, lançada pelos americanos em 1992 e adaptada à dieta brasileira em 1999 (PHILIPPI \& LATTERZA, 1999; FERREIRA \& LANFER-MARQUEZ, 2007). Já no início de 2001 a RDC nº 94 foi substituída pela RDC $n^{\circ} 40$, que obrigava a declaração dos nutrientes por porção sugerida e sua porcentagem em relação à IDR (\% VD) para uma dieta de 2500 calorias (FERREIRA \& LANFER-MARQUEZ, 2007).

Em dezembro de 2003, as RDC $\mathrm{n}^{\circ} 359$ e $\mathrm{n}^{\mathrm{o}} 360$ chegam para equiparar a legislação brasileira à dos países da América Latina que compõem o Mercosul. A 
RDC $n^{\circ} 360$ passa a chamar de rotulagem nutricional a declaração obrigatória do valor energético e de nutrientes (carboidratos, proteínas, gorduras totais, saturadas, gorduras trans, fibra alimentar e sódio) e a informação nutricional complementar. A RDC $\mathrm{n}^{\circ} 359$ reduz a base da alimentação diária brasileira de 2500 para 2000 calorias (FERREIRA \& LANFER-MARQUEZ, 2007).

Mudanças e discussões sobre a legislação de rotulagem são constantes. Mais recentemente, propostas alternativas e não oficiais de rotulagem nutricional para a parte da frente da embalagem (front-of-package labels, ou FOP labels) e também para o varejo passaram a aparecer principalmente na Europa e nos Estados Unidos, acompanhadas de estudos sobre sua eficácia, conforme será detalhado no próximo tópico deste capítulo. Mas é possível observar que o paradigma em que todas essas variações se sustentam permanece o mesmo.

A rotulagem nutricional foi introduzida como uma estratégia da segunda fase da ciência da nutrição (CANNON, 2003, p. 19). A primeira fase teve origem no início do século XIX, quando as proteínas, os carboidratos e a gordura foram descobertos como entidades separadas, e preocupação principal era o crescimento em crianças. A segunda fase veio com a descoberta das propriedades das vitaminas e outros micronutrientes, e a preocupação central passou a ser a prevenção de doenças relacionadas a deficiências em adultos. A abordagem química dos alimentos originária da Fase Um permaneceu e foi aplicada a doenças crônicas na Fase Dois. A terceira fase foi marcada pelo desenvolvimento da epidemiologia nutricional e pela pesquisa das causas químicas das doenças cardíacas (CANNON, 2003, p. 13/25; MONTEIRO et al, 2012a).

A chegada da rotulagem nutricional ocorreu num momento em que os governos aceitavam muito bem a tese de que alimentos e dietas ricos em gorduras totais e gordura saturada eram causa imediata de doença cardíaca. Por considerar os alimentos apenas por suas características químicas, ela é uma herança da Fase Um da nutrição. Por enfatizar nutrientes associados à doença cardíaca, é um fruto da Fase Dois (CANNON, 2003, p. 21-2). Na visão do autor, essa abordagem é parcialmente inútil e até perigosa. 
O autor questiona por que os rótulos informam a quantidade de proteínas e de carboidratos nos alimentos. Ele argumenta que, se o propósito dessa primeira informação é incentivar o consumo de alimentos ricos em proteína, então essa rotulagem é perniciosa, já que alimentos naturalmente ricos em proteína tendem a ser ricos também em gordura (CANNON, 2003, p. 21). Se a rotulagem não distingue carboidratos complexos naturalmente presentes nos alimentos do açúcar adicionado, ela não tem serventia. Ele diz ainda que o problema da rotulagem nutricional reside na abordagem dos alimentos do ponto de vista químico, e não em sua integralidade e modos de uso.

Rótulos nutricionais são propagandas do princípio químico da
ciência da nutrição. Suas listas de macronutrientes, elementos
químicos e vitaminas testemunham as políticas da Fase Um, a
maioria das quais ou eram sempre inúteis ou são agora
irrelevantes. As informações úteis que eles incluem são mais bem
expressas não quimicamente, mas em termos de alimentos. É
praticamente impossível ver sentido ou usar as informações sobre
a química dos alimentos em rótulos nutricionais ou em qualquer
outra forma, exceto como um exercício acadêmico, ou em
situações clínicas específicas e outras situações incomuns, ou
como um complemento para abordagens significativas (CANNON,
2003, p. 27).

Segundo o autor, a rotulagem nutricional só faz sentido quando os nutrientes abordados são tangíveis, são vistos e conhecidos pelas pessoas. É o caso da gordura, que é reconhecida por todos na carne, no leite, nos óleos. Mas proteínas, carboidratos e vitaminas não passam de conceitos abstratos para a maioria das pessoas. São invisíveis, imperceptíveis, não têm sabor ou cheiro específico, são impossíveis de identificar e contar no prato de comida. A solução estaria em tratar os alimentos como alimentos inteiros, não compostos químicos, inseridos em um sistema alimentar em todas as suas dimensões (CANNON, 2003, p. 27-28).

MONTEIRO et al (2012a) falam em uma quarta fase da nutrição, focada não mais na química dos alimentos e sua relação direta com as doenças, mas no entendimento de como os sistemas alimentares, com seu comércio global de produtos criados por corporações multi e transnacionais, influenciam o consumo de alimentos e a saúde das pessoas. Esses 
aspectos da nutrição certamente não estão previstos na rotulagem nutricional.

\section{Rotulagem nutricional simplificada}

Numa suposta tentativa de facilitar a leitura da informação nutricional pelos consumidores, as empresas passaram a experimentar modelos simplificados de rotulagem nutricional na frente da embalagem. Os símbolos e esquemas gráficos com informação nutricional sobre o produto na parte da frente da embalagem de alimentos processados tornaram-se tão variados no mercado norte-americano nos últimos anos que o FDA e o Institute of Medicine (IOM) recomendaram o desenvolvimento de um padrão para os FOP labels nos Estados Unidos. O IOM ficou então de examinar os modelos existentes e de que forma cada um poderia influenciar o consumidor na escolha de alimentos mais nutritivos. O objeto da pesquisa envolvia sistemas criados por fabricantes, redes de varejo, entidades do setor de saúde, especialistas em nutrição, organizações sem fins lucrativos, consórcios mistos e governos de dentro e de fora dos Estados Unidos (IOM, 2010).

O trabalho foi dividido em duas fases. Na primeira, o IOM analisaria os critérios adotados por cada um dos sistemas - senão de todos, dos mais representativos - e suas bases científicas. Na segunda, consultaria consumidores a fim de identificar quais sistemas cumpriam melhor a função de facilitar a identificação dos alimentos mais saudáveis. Segundo o relatório da primeira fase, o estudo era necessário porque, embora considerados inovadores, tais esquemas são controversos. Uma das principais preocupações se deve à diversidade de critérios encontrados, alguns dos quais conflituosos, o que levanta inevitáveis questionamentos sobre a confiabilidade desses sistemas (IOM, 2010). 
Vinte sistemas representativos do universo de rótulos nutricionais frontais encontrados no mercado norte-americano foram selecionados e agrupados em três categorias:

1. Nutrientes específicos. A parte da frente da embalagem informa, por meio de percentuais (valores diários de referência ou valores diários recomendados) ou esquemas gráficos, as calorias e a quantidade de determinados nutrientes contidas na porção sugerida de produto, seguindo os dados da tabela nutricional no verso da embalagem e os critérios das alegações de saúde.

O modelo mais usado - e preferido pelo setor industrial - dessa primeira categoria é o GDA (guidelines daily amounts; chamado no Brasil de VDR - valores diários recomendados), que deu origem a um programa lançado por indústrias nos Estados Unidos em dois momentos com nomes diferentes: Nutrition Keys e Facts Up Front (NESTLE, 2012) (Figura1). Também entram nessa classificação os diagramas que usam as cores do semáforo para indicar se os teores de determinados nutrientes estão altos (vermelho), médios (amarelo) ou baixos (verde) (Figura 2), conforme modelo proposto pela agência britânica Food Standards Agency em 2006.

Alguns sistemas usam múltiplos símbolos num mesmo produto para indicar características diversas. Um exemplo é o sistema da empresa de varejo americana Wegmans, que aplica ícones para representar vantagens nutricionais em produtos da marca própria (Figura 3). No Brasil, a rede de varejo Hortifruti usa um sistema semelhante para informar as qualidades nutricionais de frutas, legumes e verduras (Figura 4), como parte da campanha internacional " 5 ao dia", que incentiva o consumo de pelo menos cinco porções de alimentos desses grupos diariamente.

Figura 1. Modelo de rotulagem nutricional frontal do Facts Up Front. 
Disponível

http://factsupfront.org em:

Figura 2. Semáforo

nutricional.

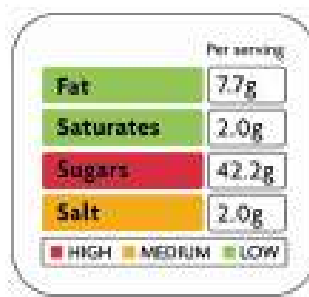

Disponível

em:

http://bit.ly/1/4J7we

Figura 3. Ícones aplicados pela empresa de varejo Wegmans Wellness Keys a produtos da marca própria.

Disponível em: http://bit.ly/1nivb1g
Figura 4. Placa com os ícones que informam as qualidades nutricionais do produto exposto numa loja da rede Hortifruti.

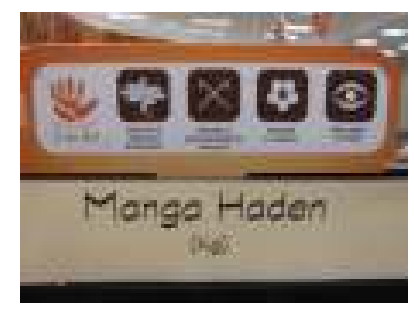

Imagem produzida pela pesquisadora

2. Indicadores sumários. Um único símbolo ou número qualifica o conteúdo nutricional do produto, com base num limite préestabelecido ou num algoritmo, sem dar informação sobre nutrientes específicos. Os sistemas dessa categoria costumam usar parâmetros distintos para diferentes categorias de produtos. Os sistemas baseados em algoritmos equacionam nutrientes a encorajar e nutrientes a evitar, chegando a uma nota-síntese, expressa na forma numérica ou icônica, que indica que o produto atende aos critérios estabelecidos. 
Um exemplo de indicador sumário numérico é o NuVal, criado por um grupo de pesquisadores da Universidade Yale, nos Estados Unidos. Consiste na atribuição de uma "nota" de 1 a 100 a qualquer tipo de alimento, desde os frescos não embalados até os mais processados. É apresentado pelo ponto de venda na prateleira do produto, não no rótulo.

O Choices e o Guiding Stars são indicadores sumários do tipo icônico. O Choices foi criado por um grupo de cientistas, autodenominados independentes, inicialmente para o mercado holandês e posteriormente adaptado para a implementação em diversos países (ROODENBURG et al, 2011). No Brasil, onde o nome do selo foi traduzido para Minha Escolha ${ }^{\mathrm{TM}}$, o programa durou pouco: foi descontinuado em $2012^{\mathrm{b}}$. Ele consistia na aplicação de um único selo (Figura 5) a produtos processados ou não que cumprem os critérios estipulados pelo programa, supostamente baseados em recomendações nutricionais oficiais.

Figura 5. Selo do programa Choices (Minha Escolha) nas versões norte-americana e brasileira.

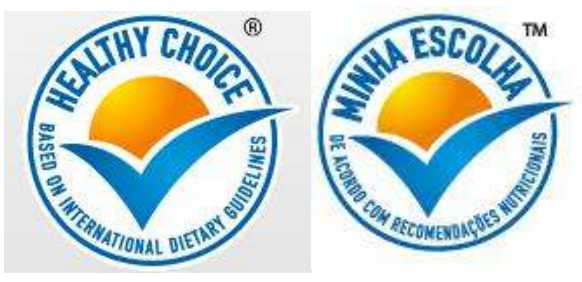

Disponível em: www.choicesprogramme.org e www.programaminhaescolha.com.br

O Guiding Stars $\mathbb{R}$, desenvolvido por uma empresa do varejo em conjunto com pesquisadores em 2006, concede de uma a três estrelas a produtos frescos ou processados, de quaisquer marcas, que atendam a critérios nutricionais mínimos estabelecidos pelo programa (FISCHER et al, 2011).

\footnotetext{
${ }^{\mathrm{b}}$ Informação confirmada pelo Choices International via e-mail em 3 fev 2014.
} 
Nessa categoria também entrariam os selos de entidades médicas, como o Selo de Aprovação SBC, da Sociedade Brasileira de Cardiologia, divulgado na página da entidade na internet como "a garantia de que você está comprando produtos diferenciados desde sua concepção e que o auxiliam na prevenção de doenças cardiovasculares (colesterol, hipertensão ou pressão alta, infarto, etc)".

Embora selos de entidades médicas tenham sido proibidos em 2011 por uma resolução do Conselho Federal de Medicina (CFM) referente à publicidade médica (CFM, 2011), o selo da SBC permanece na embalagem de produtos como bolachas e sucos processados, conforme pode ser conferido no site da entidade (SBC, 1996-2010). Segundo reportagem do jornal Folha de S. Paulo, o CFM considera abrir exceções para selos que sejam de utilidade pública, não tenham "cunho comercial", sejam educativos e apresentem comprovação científica (MISMETTI, 2012).

3. Grupo de alimentos. Símbolos indicam que o produto contém quantidade significativa de ingrediente de determinado grupo de alimentos cujo consumo deve ser encorajado.

Um exemplo é o selo Whole Grain (Figura 6), que indica a presença de grãos integrais. No Brasil, é encontrado na embalagem de pães, exatamente como na Figura 6, em inglês mesmo.

Figura 6. Selo Whole Grain nas versões básica e 100\%.
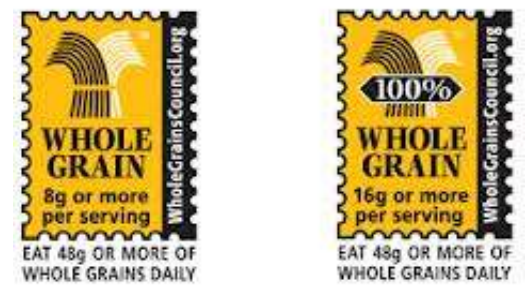

Disponível em: http://www.wholegranscouncil.org/ 
$\mathrm{Na}$ análise dos modelos de rotulagem frontal das três categorias feita pelo IOM, foi identificado que os sistemas poderiam ter o objetivo de: prover informação sobre o conteúdo calórico, a porção sugerida ou nutrientes-alvo; indicar se o produto contém alto ou baixo teor de nutrientes específicos; resumir o valor nutricional global do produto; facilitar comparações de valor nutricional intra ou entre categorias de alimentos; informar a presença de grupos de alimentos recomendados; identificar os alimentos apropriados para serem promovidos pelo marketing direcionado a crianças; ou encorajar a reformulação de produtos (IOM, 2010).

O FDA determinou em 2010 que a rotulagem nutricional frontal deveria ter como meta aumentar a proporção de consumidores que prontamente notam, entendem e usam a informação disponível para fazer escolhas mais nutritivas para si mesmos e seus familiares e assim prevenir ou reduzir a obesidade e outras doenças crônicas associadas à dieta. Dessa forma, a rotulagem frontal deveria ajudar a educar os consumidores ao mesmo tempo em que incentivaria a indústria a reformular produtos. $\mathrm{Na}$ primeira fase do estudo encomendado ao IOM, no entanto, não houve um modelo de rotulagem frontal que pudesse ser considerado $100 \%$ adequado. Segundo os revisores, todos os modelos analisados são imperfeitos e apresentam vantagens e desvantagens (IOM, 2010).

Dentre os pontos negativos identificados está a falta de transparência nos critérios adotados por sistemas baseados em algoritmos, como o NuVal. A explicação de quantas e quais substâncias são incluídas no algoritmo que dá origem a essas notas e de que forma se chega à nota de cada alimento não é apresentada ao consumidor. Sem acesso ao cálculo realizado pelos especialistas, não há como verificar por que o produto foi avaliado com tal ou qual nota.

Nos modelos baseados em nutrientes específicos, observou-se que falta um critério único para definir quais nutrientes devem ser destacados na frente da embalagem. Embora alguns considerem que a quantidade de açúcar adicionado no produto, por exemplo, deva ser destacada, os 
revisores do IOM julgam que não existe um parâmetro científico válido para determinar o limite adequado de açúcar por alimento (IOM, 2010).

Também se questionou sobre a validade de dar maior visibilidade à presença de vitaminas e minerais que usualmente não são deficitários na dieta da população. Na visão do comitê analisador, somente os nutrientes que precisam ser drasticamente diminuídos ou aumentados na alimentação da média populacional deveriam receber tratamento especial nos rótulos (IOM, 2010).

Os analistas consideraram ainda que os consumidores podem confiar excessivamente no símbolo do rótulo a ponto de ignorar o tamanho da porção que irão consumir. Outra preocupação levantada é que a indústria lance mão da fortificação de alimentos para merecer determinados selos, sendo que a presença de nutrientes sintéticos e menos estáveis nem sempre torna os produtos verdadeiramente mais saudáveis (IOM, 2010, p. $67)$.

Numa comparação entre as avaliações feitas pelos diferentes sistemas de rotulagem frontal para um conjunto de produtos alimentícios do mercado norte-americano, o IOM mostrou que os mesmos alimentos receberam tratamentos bastante diversos. Um queijo cheddar com teor reduzido de gordura foi aprovado segundo os critérios de dois sistemas do tipo indicador sumário e reprovado pela maioria dos demais. Um leite desnatado recebeu nota próxima da máxima (91) no NuVal e ficou de fora da lista de produtos com o selo Choices (IOM, 2010, p. 69).

Num artigo do European Journal of Clinical Nutrition (ROODENGURG et al, 2011), o programa Choices é apresentado como "uma ferramenta transparente e cientificamente embasada criada para encorajar consumidores e produtores em direção a um mercado de alimentos mais saudável".

O receio diante de tanta diversidade é que a "educação nutricional" oferecida aos consumidores via rótulo fuja ao controle das autoridades de 
saúde e termine sendo incompatível com as recomendações oficiais. O episódio em que o FDA enviou uma carta à responsável pelo sistema Smart Choices (hoje desativado) manifestando preocupação com alegações enganosas ficou marcado como o grande exemplo do que deve ser evitado. A carta havia sido motivada pela presença do selo Smart Choices na embalagem do Froot Loops ${ }^{\circledR}$, um produto da categoria de "cereais matinais" direcionado ao público infantil com corantes e reconhecido alto teor de açúcar adicionado. Pouco depois, o selo Smart Choices desapareceu do mercado (IOM, 2010; BROWNELL \& KOPLAN, 2011). O Smart Choices e o Choices, apesar do nome e do símbolo semelhantes, são programas distintos.

Por trás dos diferentes critérios de avaliação adotados por esses sistemas parece estar uma diversidade de conceitos de alimento e alimentação saudável. O relatório do IOM deixa claro que a definição do termo "saudável" no contexto de um mercado de alimentos em constante transformação não é unânime nem uniforme entre uma categoria de produto e outra.

Em seu Apêndice $B$, o relatório apresenta sua própria definição. Alimento saudável seria aquele com a seguinte composição na porção normalmente consumida: $\leq 3 \mathrm{~g}$ de gordura total; ( $\leq 1 \mathrm{~g}$ de gordura saturada ou $\leq 15 \%$ das calorias); $\leq 480 \mathrm{mg}$ de sódio; $\leq 60 \mathrm{mg}$ de colesterol; $\geq 10 \%$ VD das vitaminas A e C, cálcio, ferro, proteína e fibra (exceto para frutas e hortaliças cruas, ingredientes isolados, certas misturas e determinados cereais enriquecidos). Refeição saudável (inclusive industrializada) seria aquela com a seguinte composição: $\leq 3 \mathrm{~g}$ de gordura total a cada 100 gramas de comida ou $\leq 30 \%$ das calorias; ( $\leq 1 \mathrm{~g}$ de gordura saturada a cada 100 gramas de comida ou $\leq 10 \%$ das calorias); $\leq 600 \mathrm{mg}$ de sódio por porção sugerida no rótulo; $\leq 90$ mg de colesterol por porção sugerida; $\geq 10 \%$ VD de pelo menos três dos seguintes nutrientes por porção sugerida: vitamina A, vitamina C, cálcio, ferro, proteína e fibra (IOM, 2010, p. 103). 
Note-se que tais definições são inteiramente baseadas na composição nutricional dos produtos alimentícios, não considerando enriquecimento, grau de processamento, uso de aditivos, uso de químicos agrícolas, uso de irradiação, presença de organismos geneticamente modificados ou local de origem.

Convém observar que há uma diferença nem sempre sutil entre "saudável" e "mais saudável". "Mais saudável" pode muitas vezes significar "ligeiramente menos nocivo". É o que observam LOBSTEIN \& DAVIS (2008), que também analisaram sistemas de avaliação de perfis nutricionais usados em rótulos, como o Traffic Lights System, do Reino Unido; o Keyhole, da Suécia; o Sensible Solutions, da Kraft Foods; e o VDR, usado por diversas marcas no mundo todo. O objetivo desses sistemas deveria ser ajudar o consumidor a distinguir os melhores e os piores itens do mercado, mas, segundo os autores, a maioria não identifica claramente quais são os produtos menos saudáveis. Em vez disso, esses esquemas serviriam de incentivo para a indústria reformular produtos e para atrair consumidores em direção a opções ligeiramente mais saudáveis (LOBSTEIN \& DAVIES, 2008).

Para BELLATTI \& SIMON (2011), a rotulagem frontal, tal como é usada hoje nos Estados Unidos, não passa de uma ferramenta ineficiente, criada dentro do paradigma da indústria de alimentos processados como mais uma estratégia de marketing para produtos nutricionalmente inferiores.

A rotulagem frontal meramente repete o que já está dito na tabela nutricional dos alimentos embalados, não aborda as causas mais importante da obesidade e doenças crônicas e permite que as empresas de alimentos reformulem seus produtos de tal forma que continuem entregando nutrição mínima e ingredientes questionáveis. (...) vai beneficiar apenas alimentos processados de conveniência (cereais matinais, bolachas tipo cracker, biscoitos, sorvete e pratos congelados, para citar alguns). Se a rotulagem frontal se traduz em vendas aumentadas, sua implementação levará os consumidores americanos a consumir maiores quantidades de alimentos processados, exatamente aqueles que contêm maiores quantidades de calorias, óleos ômega 6, gordura trans, açúcar adicionado e sódio (BELLATTI \& SIMON, 2011). 
Um dos motivos da reprovação desses modelos é a regra da avaliação do perfil nutricional dos produtos a partir da porção sugerida. A liberdade com que os fabricantes escolhem o tamanho da porção sugerida facilita que mascarem perfis nutricionais ruins com porções reduzidas (LOBSTEIN \& DAVIES, 2008). O foco nos nutrientes, no caso do VDR, abre a possibilidade de os fabricantes fortificarem seus produtos para melhorar seus indicadores no rótulo (BROWNELL \& KOPLAN, 2011). Outro problema é que raramente esses esquemas são aplicados a alimentos que deveriam ser preferidos pelas pessoas, como grãos integrais, frutas e hortaliças, e nenhum faz propaganda negativa de produtos não saudáveis com mensagens do tipo 'coma menos' ou 'consuma apenas ocasionalmente' (LOBSTEIN \& DAVIES, 2008). Quem ousaria ser tão honesto e explícito contra sua própria mercadoria?

No caso do programa Smart Choices, criado por um grupo de corporações de alimentos, $60 \%$ dos produtos que receberam o selo não atendiam aos critérios oficiais de classificação de alimentos saudáveis (ROBERTO et al, 2011).

Tentativas de resumir quantitativamente a qualidade de um alimento envolvem o risco de abandonar informações importantes. Para LOBSTEIN \& DAVIES (2008), algumas ideias são louváveis, como avaliar os alimentos conforme a densidade energética, mas isso não diz tudo e ainda há o risco de os fabricantes "diluírem" o teor de energia de seus produtos adicionandoIhes água. $\mathrm{O}$ uso das cores do semáforo no rótulo é destacado como mais fácil de entender e usar que o modelo do VDR em diversos estudos e experiências práticas no mercado (HAWLEY, 2012; ROBERTO et al, 2012; HERSEY et al, 2013), mas tem o inconveniente de apresentar múltiplos signos a um só tempo, o que dá margem para o consumidor titubear no processo decisório. Para LOBSTEIN \& DAVIES (2008), o ideal seria que os rótulos permitissem comparar produtos intra e entre categorias. Quando a comparação que o rótulo permite é limitada, ainda que devido à dificuldade de categorizar produtos, ele é menos útil (LOBSTEIN \& DAVIS, 2008). 
Numa breve descrição cronológica da criação desses sistemas, o relatório do IOM sugere que fabricantes e varejistas lançaram seus próprios modelos de rotulagem frontal por estarem interessados em aumentar a venda de seus próprios produtos, ao passo que os grupos não lucrativos pareciam mais preocupados em dar ao consumidor uma noção mais geral do que havia no mercado, independentemente da marca (IOM, 2010).

Programas privados mudaram de nome (NESTLE, 2011), passaram por cima do trabalho de especialistas e venceram disputas contra programas melhores propostos por agências regulatórias na base do lobby bilionário (BROWNELL \& KOPLAN, 2011; IDEC, 2012). E a proposta mais avançada de rotulagem nutricional frontal aceita pelo mercado até agora foram as combinações do Traffic Lights System com o GDA, como a anunciada pela agência britânica de controle dos alimentos (Food Standard Agency), que não apresenta novidades (NESTLE, 2012) (Figura 7).

Figura 7. Modelo misto e rotulagem nutricional para a parte da frente da embalagem proposto pela Food Standard Agency no Reino Unido.

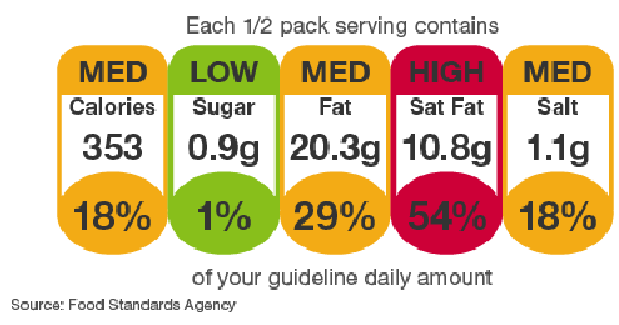

Extraído de: NESTLE (2012)

Como já foi dito anteriormente, todos esses modelos partem de um mesmo paradigma científico que vê os alimentos como meros veículos de nutrientes, sem considerar todas as suas dimensões químicas, biológicas, culturais, sociais e políticas. Algumas dessas dimensões são contempladas pelos chamados ecorrótulos. 


\section{Ecorrótulos}

A partir do final dos anos 1990, selos sociais e ambientais tornaram-se comuns e abundantes nos países desenvolvidos, principalmente para identificar produtos da agricultura orgânica, marcas comprometidas com o comércio justo e a preservação de florestas, conforme padrões estabelecidos por setores públicos e privados (indústria, varejo e ONGs). Mais tarde, surgiram também parâmetros para avaliar processos produtivos segundo ideais de proteção mais global ao meio ambiente, direitos humanos e trabalhistas, saúde e segurança no trabalho, equidade social e qualidade de vida em comunidades locais (ALBERT, 2010, p.117).

Um ecorrótulo pode ser definido como um símbolo que aparece na embalagem com a finalidade de informar ao consumidor que o produto é significativamente menos danoso para o ambiente do que produtos semelhantes (TANG et al, 2004). Para o mercado, adotar esses ecorrótulos era muitas vezes uma questão de vantagem comercial, pois os produtos com essas identificações podiam ser vendidos como categorias premium, por preços mais altos, ou ainda significar custos mais baixos, e também promover uma imagem mais positiva da marca (ALBERT, 2010).

A agricultura orgânica tornou-se um valor importante para o mercado de alimentos quando os problemas ambientais associados à agricultura industrial tornaram-se conhecidos: o desmatamento desenfreado em nome da ampliação das áreas de plantio de grãos; o uso frequente de agroquímicos; poluição da terra, de rios e de aquíferos; redução da biodiversidade. Com o grande espaço cedido pela mídia à divulgação desses problemas e a pressão de ONGs ambientalistas, as empresas passaram a voluntariamente modificar processos e comunicar melhorias em direção à redução desses impactos.

Um caminho comum para essas mudanças é contratar empresas certificadoras independentes (não interessadas nas vendas do produto certificado) para comprovar que o produto foi feito segundo determinado conjunto de regras. $\mathrm{O}$ setor produtivo tem liberdade para escolher quais certificações irá adotar, de acordo com seus processos e possibilidades. A certificação de produtos orgânicos, por exemplo, é 
aplicável à produção de commodities no campo. Ela certifica que o agricultor gerencia sua fazenda com o objetivo de garantir e melhorar a saúde do agroecossistema em que opera, sem a introdução de recursos externos a esse sistema, como fertilizantes minerais, agrotóxicos e sementes transgênicas. As primeiras certificadoras eram organizações independentes, mas atualmente muitos países adotam padrões nacionais (ALBERT, 2010, p.117).

Além das certificações de orgânicos, os alimentos também podem ser rotulados conforme parâmetros de comércio internacional justo, focados no desenvolvimento sustentável, e medidas de proteção da natureza. A página da Organização de Agricultura e Alimentação das Nações Unidas (FAO) na internet sobre rótulos de alimentos divide os rótulos em quarto tipos: nutricionais, sociais, ambientais e de segurança (FAO, 2013).

Selos e outros esquemas de diferenciação de alimentos e produtos comestíveis são desenvolvidos por governos (com objetivos regulatórios), entidades privadas independentes (focadas em promover melhoria de processos), associações de empresas e empresas isoladas (interessadas em diferenciar seus produtos e marcas e garantir vantagens comerciais) (CASWELL \& ANDERS, 2011), e em alguns casos são voltados para relações business-to-business.

O site Ecolabels Index, autodeclarado o maior diretório de ecorrótulos, registrava em dezembro de 2012 um total de 432 ecorrótulos no mundo todo, 146 deles aplicados a alimentos. Em fevereiro de 2014, a busca pelo termo "food" no sistema do site trouxe 58 resultados (ECOLABEL INDEX, 2013). Levantamento feito pelo Instituto Brasileiro de Defesa do Consumidor (Idec) em 2008 identificou mais de 30 certificadoras socioambientais no Brasil (VASCONCELOS et al, 2008), variedade que poderia dificultar o uso dos selos pelo consumidor. Em 2004, outro levantamento do Idec já havia identificado 23 selos de qualidade aplicados a alimentos, alguns focados no produto, outros no processo de produção (IDEC, 2004).

A proliferação de esquemas opcionais é considerada preocupante, pois aumenta as chances de que o consumidor seja confrontado com mensagens conflitantes, e ao mesmo tempo vista como saudável, pois leva a comparações questionadoras. "Os 
benefícios da rotulagem poderão ser reduzidos ou ter efeito geral negativo se as certificações concorrentes forem difíceis de entender, verificar ou confiar" (CASWELL \& ANDERS, 2011).

CASWELL \& ANDERS (2011) notaram que os governos podem enxergar a necessidade de incluir determinada informação num rótulo de quatro maneiras diferentes, conforme as crenças dominantes no país no momento da regulação: se o governo entende que o público 1) precisa saber ou 2) tem o direito de saber, a rotulagem tende a ser obrigatória; se entende que o público 3) quer saber, define regras para a rotulagem opcional; se entende que 4) é preciso prevenir fraudes na comunicação sobre os produtos, estabelece normas técnicas para a rotulagem de todas as categorias de produtos. A decisão dos governos de impor ou não ao setor produtivo determinada rotulagem depende, portanto, de conhecer a dinâmica das demandas por informação, além dos riscos envolvidos, das questões econômicas que a rotulagem implica e dos acordos internacionais. Naturalmente as demandas, os riscos e os custos mudam ao longo do tempo, dando origem a novas regras de rotulagem.

GOLAN ET AL (2001) examinaram a economia da rotulagem de alimentos, com o objetivo de entender de que modo a distribuição dos custos envolvidos na divulgação de determinadas informações influencia as decisões dos governos sobre a rotulagem. No caso da informação nutricional e da agricultura orgânica, que já tiveram sua fase de não regulação, os governos dos Estados Unidos e do Brasil, por exemplo, decidiram estabelecer normas para a rotulagem. No Brasil a rotulagem de transgênicos é obrigatória, o que nos Estados Unidos foi aprovado apenas em Vermont até junho de 2014, sob protesto (DAILY MAIL, 2014).

Para as empresas, por sua vez, a opção por informar determinada característica do produto ou do processo produtivo no rótulo segue a mesma lógica do planejamento de qualquer peça publicitária e requer o mesmo tipo de conhecimento de seu público-alvo (GOLAN et al, 2001).

Governos optam por regular a rotulagem quando esta tem potencial para contribuir para o alcance de alguma meta social, como a segurança e a saúde da 
população, a redução de danos ambientais, proteger o país em disputas comerciais ou favorecer a agricultura e a indústria nacionais. Quando o custo de não informar é maior que o de informar - por exemplo, mais internações no sistema de saúde decorrentes de um consumo desinformado e excessivo de produtos prejudiciais à saúde -, a rotulagem torna-se viável e desejável, mesmo se os custos privados não forem compensados.

Garantir ao consumidor informação relevante também é indicado quando o mercado não informa o suficiente para o consumidor fazer as escolhas que mais lhe agradem (direito de saber). A situação em que o fabricante tem informações que o consumidor desconhece é chamada de informação assimétrica. Trata-se de um problema, pois a informação assimétrica pode levar o consumidor a adquirir produtos que não atendem a suas preferências. "Nesse caso, o mercado não funciona com eficiência: bens que poderiam ser lucrativos com total transparência podem não ser produzidos, e sim aqueles de menor valor para os consumidores." Assim, corrigir a assimetria da informação é uma forma de tornar o mercado mais eficiente (GOLAN et al, 2001, p. 136-7).

A informação assimétrica difere da informação imperfeita ou ausente, em que a informação não existe ou é contraditória. Este seria o caso da informação sobre os alimentos geneticamente modificados. As espécies de sementes transgênicas são diferentes entre si, seus efeitos de longo prazo na saúde e no meio ambiente ainda não são inteiramente conhecidos e o monopólio das empresas que produzem essas sementes afeta o desenvolvimento dos agricultores, mas ainda assim os produtos dessa tecnologia são divulgados oficialmente como alimento seguro (ROBIN, 2008).

Os ecorrótulos de uso opcional (não obrigatórios) são comumente criados pelas organizações ambientalistas como instrumento para o consumo político a fim de mobilizar a opinião pública. Mas KLINTMAN (2006) os considera simplistas e fracos como substitutos de medidas regulatórias. Sobre as certificações socioambientais, o site da FAO diz que

Padrões voluntários e sistemas de certificação podem beneficiar fazendeiros e trabalhadores rurais, pois têm o potencial de gerar retorno sobre o trabalho no campo, melhores condições de trabalho e melhorias duradouras no meio ambiente. Podem oferecer a pequenos agricultores 
uma oportunidade de permanecer no negócio, por meio do apoio de consumidores dispostos a pagar um preço premium. Essas iniciativas podem também beneficiar comunidades locais no entorno das fazendas. Quando levam ao desenvolvimento local por meio de incremento na renda, da geração de emprego e da capacitação, beneficiam a sociedade como um todo (FAO, 2013).

Porém, para KLINTMAN (2006), os ecorrótulos, particularmente os de produtos orgânicos, estão longe de apresentar com fidelidade os reais impactos da produção, comercialização e consumo dos produtos rotulados, pois são uma tradução simplificada de conhecimentos cientificamente complexos e incertos e ideologicamente diversos, que deixa de fora algumas questões para priorizar outras. GUNTHER (2013) afirma que certos ovos rotulados como orgânicos na verdade são produzidos em granjas intensivas e diz que, se imagens reais da produção fossem estampadas nas embalagens em vez de ilustrações bucólicas, os consumidores passariam longe desses produtos.

Para DALMENY (2007), a complexidade dos impactos ambientais ao longo da cadeia agroindustrial e seus métodos de aferição tornam improvável que a informação nos rótulos seja precisa e leve com segurança a escolhas informadas. Em muitos casos, diz a autora, só resta aos consumidores tentar adivinhar quais são as opções mais sustentáveis.

MACRAE et al (2012) encontraram definições para o termo "comida local" que variam de $50 \mathrm{~km}$ a mais de $200 \mathrm{~km}$ de distância entre o local de produção e o de consumo, o que evidencia a falta de homogeneidade no tratamento do tema de um lugar a outro.

E como julgar quais impactos são mais importantes? A rotulagem de orgânicos tornou-se comum em diversos países, mas a de comércio justo, nem tanto. A indicação de origem é importante na Europa, mas não nos Estados Unidos. Segundo CASWELL \& SANDERS (2011), faltam estudos empíricos sobre as justificativas para essas discrepâncias. Sem parâmetros universais, como rotular os alimentos e em que direção modificar o hábito de compra dos consumidores?

Quando os parâmetros não são corretos ou a comunicação não é clara, a rotulagem pode gerar imperfeições no mercado, em vez de corrigi-las. Para CASWELL \& SANDERS (2011), "as certificações serão aceitas como sinais de 
credibilidade no mercado somente se lograrem estabelecer uma reputação positiva e uma relação de confiança entre os parceiros de negócio”. IRALDO et al (2013) afirmam que "alegações verdes corretas, baseadas em métodos de verificação e comunicação padronizados e largamente reconhecidos, podem fornecer aos consumidores a informação de que eles precisam para fazer decisões de compra ambientalmente sãs”.

Mas há casos em que determinada rotulagem pode prejudicar o sistema alimentar. GETZ \& SHRECK (2006) relatam que a certificação de orgânicos no México exacerbou desigualdades socioeconômicas por ter atraído uma atenção exagerada à vigilância e ter desconsiderado os modos tradicionais de produção, situação gerada por uma provável análise parcial dos custos, benefícios e impactos da certificação.

Para GOLAN et al (2001), a rotulagem só terá o efeito desejado se todas as etapas que ela requer forem cumpridas (Figura 8).

O governo deve assegurar que os padrões estabelecidos sejam claros e alcançáveis; que os laboratórios de testes, se necessário, estejam disponíveis para validar as alegações nos rótulos; que produtores (e consumidores) estejam aptos a averiguar ou provar a validade das alegações de qualidade; e um mecanismo de garantia de cumprimento das regras da rotulagem existam, inclusive para punir produtores que fizerem alegações fraudulentas (GOLAN et al, 2001).

Figura 8. “Árvore da rotulagem”. 


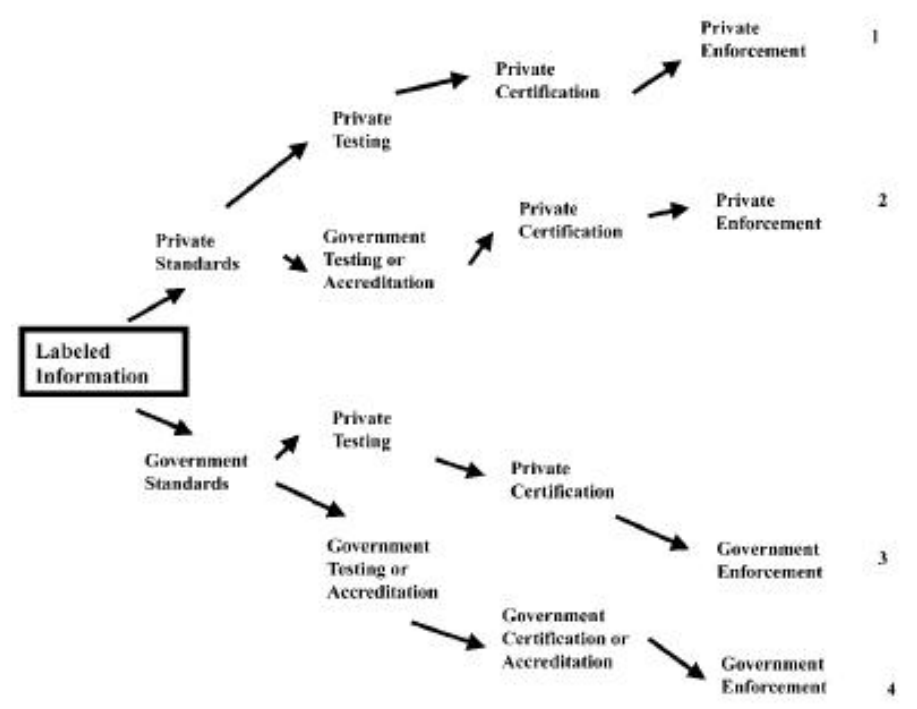

Extraído de: GOLAN et al (2001).

Ainda que siga todas essas recomendações, lembremos que a rotulagem só poderá funcionar se o consumidor se der ao trabalho de ler a informação e der alguma importância a ela. A literatura mostra que a leitura de qualquer rótulo é mais provável quando ele é claro e conciso. $\mathrm{O}$ excesso de informações e alertas tende a gerar desinteresse. Para GOLAN et al (2001), a rotulagem pode funcionar bem para resolver problemas de informação assimétrica, mas não serve para tentar esclarecer dúvidas em casos de informação imperfeita - e deixar o consumidor confuso não torna o mercado mais eficiente.

\section{Novas propostas para a rotulagem}

Tentativas de responder a todos esses desafios foram elaboradas por pesquisadores, jornalistas e designers. São propostas que, embora ainda imperfeitas, trazem inovações importantes que podem servir de inspiração para a criação de novos modelos de rótulos. 
A Escola de Jornalismo da Universidade da Califórnia em Berkeley, nos Estados Unidos, em parceria com a revista Good, lançou em 2011 o projeto Rethink the food label (repensar o rótulo de alimentos), cujo propósito era criar um modelo melhor de rotulagem, num esforço paralelo ao encampado pelo IOM. Designers foram chamados a trazer novas ideias para um concurso, do qual participariam como jurados o jornalista e professor dessa universidade Michael Pollan, o médico Robert Lustig, o ativista Michael Jacobson, a designer Laura Miner e o professor de design Andrew Moere (PARKER-POPE, 2011).

A expectativa dos jurados era que os concorrentes propusessem soluções para os problemas que eles identificavam nos modelos de rótulos praticados no mercado. Pollan defendia que o grau de processamento do alimento era frequentemente mais importante do que os nutrientes. Miner desejava que o leitor do rótulo pudesse rapidamente captar em que medida o produto atende ou não suas expectativas e preocupações, conforme o contexto do consumo. Para Lustig, a quantidade de açúcar adicionado deveria necessariamente ser declarada, o que raramente acontece. Para Moere, o uso de números como principal forma de esclarecimento era o maior problema, pois as pessoas não são assim tão boas em matemática para calcular tudo que os rótulos lhes exigem. Moere defendia também que os rótulos permitissem comparações por diversos ângulos, conforme os valores individuais de cada pessoa, e que isso fosse pensado a partir de dados reunidos do marketing, da psicologia social, da economia e outras ciências. Jacobson via nos termos científicos, além dos números e percentuais, um grande obstáculo à boa leitura dos rótulos. Ele também defendia a inclusão, em algum lugar da embalagem, separado da informação nutricional, de dados sobre os métodos produtivos: se era orgânico ou não; como os animais eram tratados; e até se os trabalhadores rurais eram sindicalizados (NEWS21, 2011).

O modelo que venceu o concurso foi o de Renne Walker (Figura 9), focado na informação nutricional. Para Pollan, trata-se de um design promissor por mostrar de forma visual a composição do produto, mas fazer isso com itens com grande número de ingredientes poderia ser complicado. Moere o considerou atrativo e moderno, mas sentiu falta de informações detalhadas sobre os ingredientes, inclusive os ausentes. 
Figura 9. Modelo de rotulagem nutricional criado por Renne Walker, aplicado a uma maçã (E) e a um produto semipronto a base de macarrão com queijo (D).
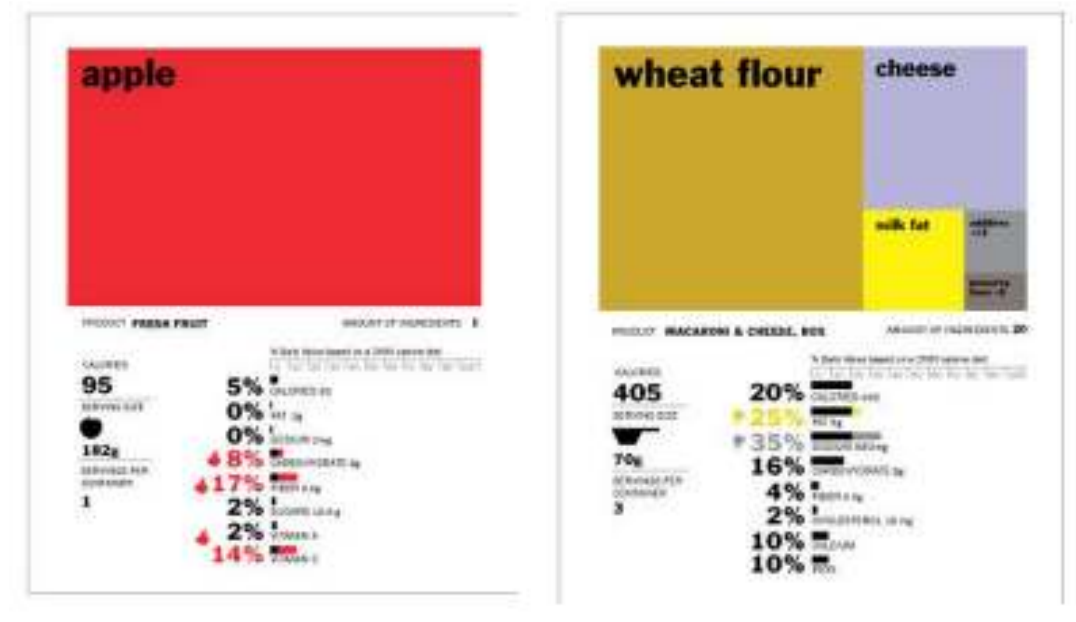

Disponível em: http://berkeley.news21.com/foodlab1/designs/renee-walker/

Conforme se observa a partir dos comentários dos jurados, apesar das inovações e da criatividade, os modelos vencedores merecem aprimoramentos. Nenhum deles preencheu as lacunas referentes ao grau de processamento e aos impactos socioambientais dos alimentos. Essas questões foram abordadas em outras criações elogiadas pelo júri e ainda assim mereceram críticas (NEWS21, 2011).

Uma proposta de representação gráfica simplificada e integrada de diversos impactos positivos, evolvendo toda a cadeia agroalimentar, foi apresentada pela revista Sustain em 2007. Cada categoria de impacto seria medida numa escala de zero a 3 e representada por um raio partindo de um centro (zero), sendo zero o impacto nulo e 3 o impacto mais desejado. Impactos negativos não são contemplados no método.

Nesse modelo, a pontuação alcançada pelo produto em cada categoria de impacto é marcada no respectivo raio, dando origem a um diagrama em forma de flor, cujas pétalas podem ter cores distintas, aproveitando o modelo do semáforo. Assim, em vez de números, percentuais e termos técnicos, o consumidor veria 
pétalas de tamanhos variados representando consequências desejadas e indesejadas da escolha do produto (SUSTAIN, 2007).

No exemplo apresentado na Figura 10, a empresa alcançou pontuação razoável nas categorias uso de água e comércio justo, mas deixou a desejar em outras categorias. Se tivesse nota máxima em todas as categorias, o diagrama resultante seria um perfeito heptágono. Com não foi assim, as pétalas são desiguais.

Figura 10. Representação de sete categorias de impactos de um produto no sistema alimentar em cinco fases (em sentido horário): seleção das categorias e escalonamento dos impactos na forma de raios; marcação das pontuações; avaliação das pontuações; estetização e aplicação de sistema de avaliação por cores (vermelho: baixo desempenho; laranja: desempenho mediano; verde: bom desempenho); aplicação combinada da avaliação por cores e tamanhos.
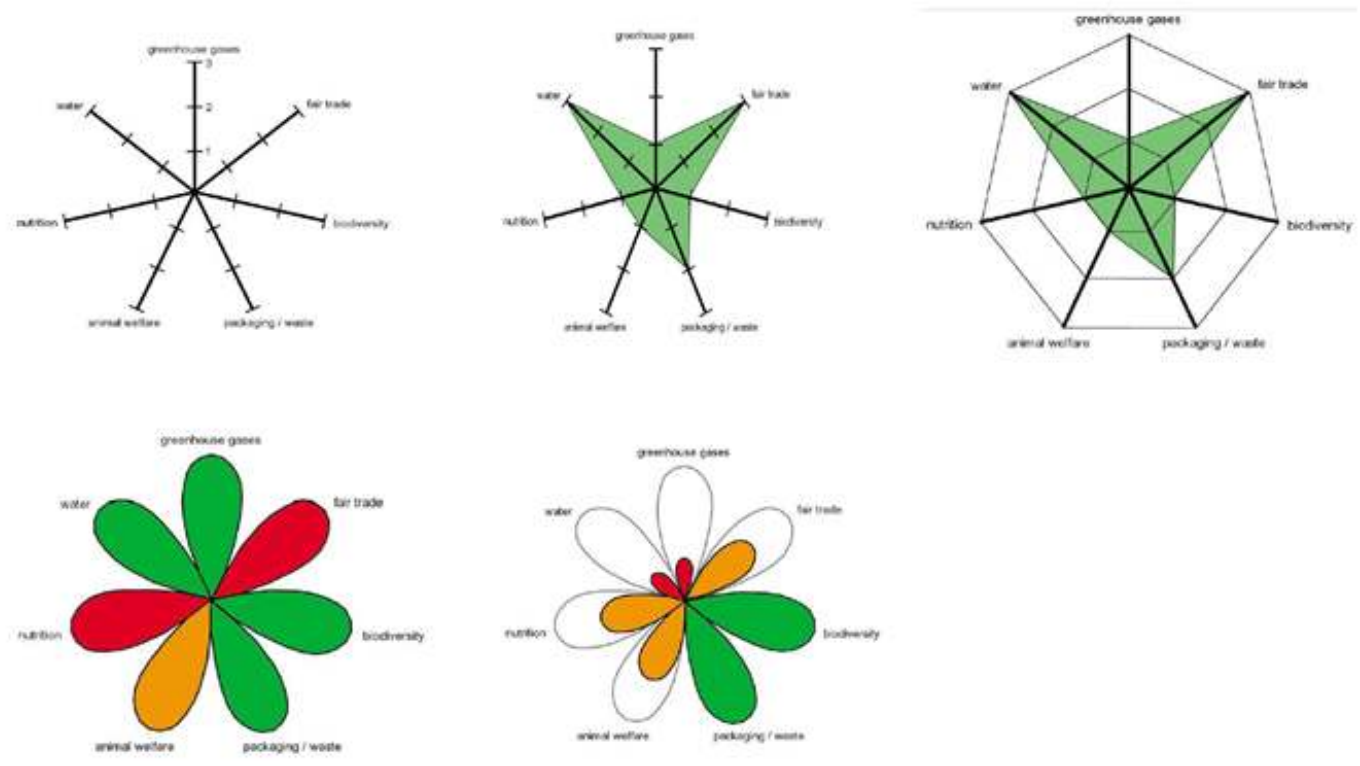

Extraído de: SUSTAIN (2007)

Outras ideias para a simplificação da rotulagem são trazidas por BITTMAN (2012). O jornalista defende que os rótulos revelem os teores de foodness e fakeness dos produtos comestíveis, ou seja, quão comida e quão mentira eles são. "Isso permitira saber à primeira vista, para além da informação nutricional acurada, se o alimento contém gordura trans, resíduos de hormônios, antibióticos, pesticidas ou outros químicos, ingredientes geneticamente modificados ou qualquer outro 
ingrediente que não pertence ao alimento em seu estado natural", além de como a produção afetou o bem-estar dos trabalhadores envolvidos e o meio ambiente, a pegada de carbono e as origens do alimento (BITTMAN, 2012).

$\mathrm{Na}$ tentativa de responder aos próprios anseios, BITTMAN (2012) apresentou sua própria proposta. A primeira versão de seu "rótulo ideal" tem um código de cores aplicado a uma escala de 15 pontos: o verde indica pontuação entre 11 e 15; o amarelo, 6 a 10 pontos; e o vermelho, zero a 5 pontos. Três quesitos são avaliados: nutrição, foodness e bem-estar social.

No quesito nutrição, são avaliados os mesmos nutrientes de sempre. Refrigerantes levariam pontuação zero e brócolis congelado, 5 pontos (no sistema $\mathrm{NuVal}$, o brócolis fresco é um dos poucos itens com pontuação máxima). Um quadro à parte indica a presença ou ausência de ingredientes geneticamente modificados.

No quesito foodness, avalia-se quão perto o produto está de ser comida de verdade (o que antigamente seria chamado de natural, mas este termo foi evitado, segundo BITTMAN (2012), por estar adulterado e sem seu sentido original). O mesmo brócolis, congelado, levaria 4 pontos nesse quesito, e não 5, pois foi processado.

O quesito bem-estar social, o mais amplo e complexo, inclui as formas de tratamento dos trabalhadores, dos animais e do planeta. Perguntas como "Os trabalhadores são tratados como animais?”, “Os animais são criados como peças numa linha de montagem?" e "O dano ao meio ambiente é significativo?" devem ser respondidas em conjunto. Se a resposta para as três perguntas for "sim", o produto tem grandes chances de receber um zero nesse quesito, o que segundo BITTMAN (2012) seria o caso do frango de granjas industriais. 


\section{Rótulos fora da embalagem}

Quase todos os modelos de rotulagem discutidos até aqui foram criados para aplicação na embalagem dos alimentos. Embalagens são também produtos e resultam de processos de produção de massa que dependem de insumos, maquinário, papel e/ou plástico, gráfica, distribuição. São produzidas grandes quantidades. E, assim como produtos comestíveis, têm prazo de validade. Quer dizer, qualquer alteração que tiver de ser feita numa embalagem terá de aguardar o fim dos estoques, o que levará algum tempo. Ou seja, alterações nos rótulos não podem ser feitas imediatamente. Informações novas chegam aos rótulos sempre com atraso.

Além da rotulagem de prateleira, cujos exemplos neste trabalho são o sistema NuVal e os ícones da rede Hortifruti, o uso de mídias digitais para oferecer ao consumidor informações adicionais também sinaliza uma alternativa interessante à rotulagem convencional.

Na própria rede Hortifruti, parte da informação ao consumidor dentro da loja é apresentada por meio de etiquetas com um tipo de link conhecido como $Q R$ code aplicadas a alguns produtos. Utilizando um telefone móvel conectado à internet, o cliente pode fazer a leitura do código e acessar um conteúdo digital que não teria como entrar na etiqueta, como por exemplo um vídeo do produtor da mercadoria em questão (HORTIFRUTI, 2012). A tecnologia do $Q R$ code associada à internet móvel permite o acesso a qualquer formato digital de informação.

Os smart phones têm potencial para se tornar grandes aliados da rotulagem de alimentos, se usados com inteligência e independência. Na Austrália, o The George Institute for Global Health criou um aplicativo para telefones móveis, chamado Foodswitch, que lê os códigos de barras de 28 mil produtos alimentícios e aplica a eles o semáforo nutricional (THE GEORGE INSTITUTE, 2013).

Nos Estados Unidos, os smart phones também podem ser usados para ler códigos de barras e consultar a pontuação de uma infinidade de produtos de todas as categorias, entre eles alimentos, nos quesitos impacto nutricional, impacto 
ambiental e impacto social, conforme escala própria de pontos. Uma das iniciativas, batizada de GoodGuide, é de uma empresa privada fundado por Dara O'Rourke, professor da Universidade da Califórnia em Berkeley (GOODGUIDE.com, 2011). Além da consulta produto a produto, o GoodGuide permite comparar produtos de mesma categoria, formar rankings e descobrir as melhores opções disponíveis.

Entre as vantagens de apostar na informação via meios digitais está a facilidade de atualizar qualquer informação a qualquer momento. No caso de mudanças na legislação de rotulagem, que hoje envolvem prazos de meses para a atualização pelos fabricantes, a rotulagem digital permitiria que os consumidores tivessem acesso a informação correta, nos moldes das novas regras, muito antes. Outra vantagem é que nos meios digitais não há limitação de espaço, como há nas embalagens. Além disso, as tecnologias digitais permitem o uso de fontes de informação independentes dos fabricantes, o que configura uma oportunidade de descentralizar a emissão de informação crítica sobre os produtos e dissipar o poder da indústria.

$\mathrm{O}$ uso de tecnologias da informação poderia multiplicar o acesso à informação sobre produtos no momento da compra de forma nunca vista. Cálculos que o consumidor não sabe ou não se dispõe a fazer sozinho poderiam ser antecipados; gráficos ilustrativos poderiam complementar a informação dos rótulos; vídeos com imagens reais do processo de produção poderiam confirmar ou negar medidas socioambientais alegadas; termos técnicos inevitáveis poderiam ser explicados de forma simples e visual; conteúdos educativos para crianças poderiam ser adicionados. As possibilidades são muitas e devem evoluir em direção ao século XXI e à Fase Quatro da ciência da nutrição. 


\subsection{LEGISLAÇÃO DE ROTULAGEM NO BRASIL}

A legislação de rotulagem de alimentos no Brasil é constituída por um conjunto complexo de leis, resoluções, portarias, decretos e instruções normativas. O conteúdo dos rótulos está a cargo do Ministério da Justiça; a fiscalização da rotulagem nutricional é de competência da Anvisa; o Ministério da Agricultura, Pecuária e Abastecimento (Mapa) e o Ministério do Desenvolvimento Agrário (MDA) regulam a rotulagem de orgânicos, ovos, peixes, carnes e outros produtos rastreados, produtos da agricultura familiar, além de frutas e hortaliças. A decisão da obrigatoriedade de rotulagem de transgênicos envolveu também a Casa Civil. Não é fácil navegar por esse mar jurídico.

A tarefa de reunir toda a legislação de rotulagem é desafiadora. Parte importante da legislação de rotulagem de alimentos é facilmente encontrada na página da Anvisa na internet, incluindo documentos que regulam a informação direcionada à população brasileira como um todo, com base na Constituição, nos direitos humanos e nas recomendações nutricionais de base populacional, e também documentos que regulam informações direcionadas a públicos específicos, como pessoas com diabetes, doença celíaca ou alergias (ANVISA, 2005-2009). Já os documentos que compõem a legislação do Mapa demandam uma pesquisa mais cuidadosa e demorada.

O sistema de busca da página do Mapa na internet, chamado Sislegis, não é amigável para iniciantes. Uma busca simples pelos termos "rotulagem AND alimentos" traz uma lista com algumas centenas de documentos, separados por tipo, que não permite identificar rapidamente aqueles que tratam exclusivamente da rotulagem de alimentos. Tentou-se obter mais informações por telefone, mas o que se descobriu é que o Mapa é todo setorizado e que não havia uma única pessoa que conhecesse a legislação de todos os setores. 
Diante da dificuldade de localizar por meios oficiais toda a legislação pertinente, optou-se neste trabalho por uma navegação seletiva pelo site do Mapa e buscas por palavras-chave no Google Advanced.

A dificuldade de visualizar as regras para a rotulagem de forma global já de antemão sugere a existência de uma separação estrutural entre o que diz respeito à informação nutricional e o que se refere a processos produtivos. A legislação sobre rotulagem nutricional é da Anvisa; a de orgânicos é do Mapa. Assim, as informações nos rótulos são reguladas e apresentadas ao público de forma não integrada. O que é dito sobre nutrientes não está relacionado ao que é dito (ou não é dito) sobre processos produtivos e sustentabilidade. O que é dito sobre calorias não está relacionado ao que é dito (ou não é dito) sobre agrotóxicos. A presença de vitaminas e minerais nos alimentos não é de forma alguma associada na rotulagem à agricultura familiar nem à industrialização globalizada.

Examinemos primeiro o que compete à Anvisa. A legislação de rotulagem de alimentos brasileira é baseada primeiramente no Codex Alimentarius, programa criado em 1962 pela FAO e pela Organização Mundial de Saúde (OMS) e do qual o Brasil é membro desde os anos 1970. O Codex Alimentarius busca conciliar a proteção à saúde e ao direito do consumidor à informação com práticas comerciais equitativas. A rotulagem também está prevista no Código de Defesa do Consumidor (Lei no. 8.078 de 11/09/90).

Um dos documentos mais antigos sobre rotulagem em vigor é a Lei 6.437, de 1977, que impõe penas a infrações à legislação sanitária federal, dentre as quais multa para quem rotular alimentos, bebidas e produtos dietéticos contrariando as normas legais e regulamentares (BRASIL, 1977).

A Resolução RDC 259, de 2002, considera como rotulagem "toda inscrição, legenda, imagem ou toda matéria descritiva ou gráfica, escrita, impressa, estampada, gravada, gravada em relevo ou litografada ou colada sobre a embalagem do alimento." Os princípios gerais da RDC 259 tratam de coibir o uso de comunicação que leve o consumidor a não entender ou entender errado o que 
está no rótulo ou que o leve a comprar o produto por causa de característica que este não possua. $\mathrm{O}$ documento estabelece em detalhes o que os fabricantes de alimentos embalados podem e não podem informar no rótulo a fim de identificar apropriadamente do que são feitos os seus produtos. Por exemplo, determina em que ordem deve estar a lista de ingredientes, em que casos usar determinados termos e quais embalagens devem trazer informação nutricional (ANVISA, 2002b).

A rotulagem nutricional é definida como qualquer descrição presente no rótulo destinada a informar o consumidor sobre as propriedades nutricionais do alimento e deve atender aos regulamentos técnicos da Anvisa. É classificada em dois tipos: 1) rotulagem nutricional obrigatória, que consiste na declaração numérica do valor energético e de nutrientes, geralmente na forma de tabela nutricional; e 2) informação nutricional complementar, que é "qualquer representação que afirme, sugira ou implique que um alimento possui propriedades nutricionais particulares, especialmente, mas não somente, em relação ao seu valor energético e/ou ao seu conteúdo de proteínas, gorduras, carboidratos e fibra alimentar, assim como ao seu conteúdo de vitaminas e minerais" (ANVISA, 2012a). Em outras palavras, a informação nutricional complementar é toda declaração de propriedade ou alegação nutricional. Ela descreve o nível absoluto ou comparativo de determinados nutrientes ou valor energético no produto. Tem caráter opcional e é considerada um tipo de marketing (HAWKES, 2006).

A legislação de rotulagem nutricional obrigatória é a Resolução RDC 360/2003, que padroniza a declaração do valor energético e das quantidades de carboidratos, proteínas, gordura total, gordura saturada, gordura trans, fibras alimentares e sódio contidos na porção do alimento. A rotulagem nutricional obrigatória é aplicável à maioria dos alimentos e bebidas embalados e tem o propósito de facilitar ao consumidor o conhecimento das propriedades nutricionais dos alimentos, visando um consumo adequado.

Já a informação nutricional complementar (INC), composta de alegações de propriedades nutricionais tais como "rico em fibras" ou "light", é regulamentada pela RDC 54, de novembro de 2012, aplicável a alimentos e bebidas embalados, com exceção de bebidas alcoólicas, chás e erva-mate, vinagres, fórmulas infantis e 
outras categorias especiais. Segundo a RDC 54/ 2012, a INC não pode ser usada de maneira a incentivar o consumo excessivo de determinados alimentos nem dar a entender que o produto é nutricionalmente completo.

A Anvisa publicou em seu site uma lista de 76 perguntas e respostas sobre a INC, por ocasião da publicação da RDC 54, em novembro de 2012. A décima pergunta da lista é: “Os alimentos com INC são mais saudáveis do que outros alimentos?" Responde-se o seguinte:

\begin{abstract}
Não. A INC chama a atenção do consumidor para uma qualidade nutricional específica do alimento, mas não revela todas as suas características. Por exemplo, um alimento com a alegação de sem açúcares pode conter quantidades elevadas de gorduras saturadas e sódio.

Consequentemente, não é possível identificar somente por meio de uma INC se determinado alimento é mais ou menos nutritivo do que outro. Isso significa que o consumidor não deve selecionar seus alimentos somente com base na presença de uma INC. Assim, é muito importante que os consumidores também consultem a tabela de informação nutricional constante nos rótulos, uma vez que ela apresenta outras informações relevantes sobre a composição nutricional dos alimentos (ANVISA, 2012b).
\end{abstract}

A explicação acima explicita a limitação da INC como instrumento de aprendizado pelo consumidor e sua utilidade como ferramenta de marketing. Ao reconhecer que a INC pode induzir os indivíduos a erro quando a informação mais "pura" presente no rótulo - a tabela nutricional - não é consultada, a Anvisa parece tratar a INC como uma forma mista de informação e publicidade, assumindo que essa mistura não é inteiramente confiável e que somente o entendimento pleno da tabela nutricional poderia "salvar" o consumidor do engano. Essa lógica partiria da premissa de que a tabela nutricional é de fato compreensível pelos consumidores.

Além da INC, a rotulagem de alimentos pode ter ainda, em caráter opcional, alegações de propriedades funcionais e de saúde, regulamentadas pela Resolução 18 de 1999. Diferentemente do estabelecido para a INC, as alegações de propriedade funcional e de saúde não são padronizadas pela legislação, mas aprovadas caso a caso. A regra geral para aprovação é que elas sejam cientificamente comprovadas (ANVISA, 1999). 
A Resolução 408, de 2008, do Conselho Nacional de Saúde, aprova a adequação da rotulagem nutricional de alimentos como diretriz para a promoção da alimentação saudável com o objetivo de contribuir na reversão da epidemia de obesidade e na prevenção das doenças crônicas não transmissíveis. Segundo o documento, a rotulagem nutricional deve "atender às necessidades de informação da população brasileira, destacando (...) os teores de gorduras saturadas, gorduras trans, gorduras totais, sódio e açúcar" e deve ser "acompanhada por estratégias de informação e educação que facilitem a identificação e compreensão destas informações" (MS, 2009).

Como visto, na legislação de rotulagem da Anvisa, a alimentação saudável está associada essencialmente aos nutrientes. Nos parágrafos a seguir, são apresentados alguns aspectos da legislação de rotulagem ligada aos órgãos que controlam a produção agrícola.

Um dos documentos mais importantes do Mapa sobre rotulagem é a Instrução Normativa 22/2005, que trata da rotulagem de produto animal embalado. O texto revela grande preocupação em evitar dados e declarações falsas nos rótulos. $\mathrm{O}$ documento proíbe o uso de

vocábulos, sinais, denominações, símbolos, emblemas, ilustrações ou outras representações gráficas que: possam tornar as informações falsas, incorretas, insuficientes, ou que possam induzir o consumidor a equívoco, erro, confusão ou engano, em relação à verdadeira natureza, composição, procedência, tipo, qualidade, quantidade, validade, rendimento ou forma de uso do produto de origem animal; atribuam efeitos ou propriedades que não possuam ou não possam ser demonstradas; destaquem a presença ou ausência de componentes que sejam intrínsecos ou próprios de produtos de origem animal de igual natureza, exceto nos casos previstos em regulamentos técnicos específicos; ressaltem, em certos tipos de produtos de origem animal processado, a presença de componentes que sejam adicionados como ingredientes em todos os produtos de origem animal com tecnologia de fabricação semelhante; ressaltem qualidades que possam induzir a engano com relação a reais ou supostas propriedades terapêuticas que alguns componentes ou ingredientes tenham ou possam ter quando consumidos em quantidades diferentes daquelas que se encontram no produto de origem animal ou quando consumidos sob forma farmacêutica; indiquem que o produto de origem animal possui propriedades medicinais ou terapêuticas; aconselhem seu consumo como estimulante, para melhorar a saúde, para prevenir doenças ou com ação curativa (MAPA, 2005). 
O documento prevê também informações obrigatórias, entre as quais a origem. A identificação de origem é colocada como uma questão de concorrência comercial, considerando-se a associação de determinados locais com a qualidade de produtos típicos (caso dos queijos).

A segurança de uso, registro e comercialização dos aditivos utilizados na ração animal é tema da Instrução Normativa 13/2004, também do Mapa, que não trata especificamente da rotulagem. O documento estabelece parâmetros para o uso adequado de aditivos, como limites máximos, e impõe um controle rígido para o registro desse tipo de produto. Aborda-se a segurança do uso para o consumidor do produto final - por exemplo, uma peça de carne ou um litro de leite -, mas não impões regras para a informação no rótulo do produto final sobre a presença de aditivos e seus efeitos sobre a saúde (MAPA, 2004).

O Mapa também regula a rotulagem de alimentos de origem vegetal, com instruções normativas específicas para cada alimento. Desde março de 2004, frutas e hortaliças cultivadas em solo brasileiro devem ser rotuladas com nome do produtor, local de origem e outras informações destinadas ao controle pelas centrais de abastecimento. Segundo nota de divulgação do Mapa, conhecer o local de origem de frutas e hortaliças seria útil para as centrais conhecerem e rastrearem os produtores. Não há menção à necessidade de informar o consumidor final, por exemplo com a finalidade de promover o consumo de alimentos produzidos localmente (AGÊNCIA BRASIL, 2004).

Nomes e quantidades de agrotóxicos não aparecem na rotulagem dos alimentos que consumimos; apenas sua ausência é subentendida na rotulagem de alimentos orgânicos.

A agricultura orgânica é regulada pelo Decreto $n^{\circ} 6.323$, de 2007. O decreto estabelece que a agricultura orgânica tem como diretrizes: contribuir com o desenvolvimento local, social e econômico sustentáveis; desenvolver sistemas agropecuários baseados em recursos renováveis e organizados localmente; regionalizar a produção e estimular a relação direta entre o produtor e o consumidor final; promover práticas sustentáveis em todo o processo, desde a escolha do 
produto a ser cultivado até sua colocação no mercado, incluindo o manejo dos sistemas de produção e dos resíduos gerados; preservar a diversidade biológica dos ecossistemas naturais e recompor ou incrementar a diversidade biológica dos ecossistemas modificados, com atenção às espécies ameaçadas de extinção; promover relações de trabalho justas, dignas e equânimes; promover o consumo responsável e o comércio justo e solidário, baseados em procedimentos éticos; promover a oferta de produtos saudáveis, isentos de contaminantes que ponham em risco o meio ambiente e a saúde do produtor, do trabalhador ou do consumidor; promover o uso de boas práticas de manuseio e processamento com o propósito de manter a integridade orgânica e as qualidades vitais do produto em todas as etapas; adotar práticas que contemplem o uso saudável do solo, da água e do ar, de modo a reduzir ao mínimo todas as formas de contaminação e desperdícios desses elementos; utilizar práticas de manejo produtivo que preservem as condições de bem-estar dos animais; incrementar os meios necessários ao desenvolvimento e equilíbrio da atividade biológica do solo; empregar produtos e processos que mantenham ou incrementem a fertilidade do solo em longo prazo; reciclar resíduos de origem orgânica, reduzindo ao mínimo o emprego de recursos não-renováveis; e converter progressivamente toda a unidade de produção para o sistema orgânico (BRASIL, 2007).

O documento também estabelece que os produtos da agricultura orgânica sejam certificados e identificados pelo selo do Sistema Brasileiro de Avaliação da Conformidade Orgânica, hoje obrigatório. Somente os produtores da agricultura familiar que façam parte de alguma organização de controle social cadastrada nos órgãos fiscalizadores são autorizados a vender como alimentos orgânicos produtos não certificados, desde que integrem alguma organização de controle social cadastrada nos órgãos fiscalizadores (MAPA, s.d.).

Segundo o Ministério do Desenvolvimento Agrário, 70\% dos alimentos consumidos no Brasil são produzidos pela agricultura familiar, fato que o órgão pretende tornar conhecido pelas pessoas (MDA, s.d.). Com o propósito de identificar os produtos da agricultura familiar, dar-lhes maior visibilidade e favorecer sua promoção comercial, o governo federal criou em 2009 um selo para 
os produtores, de uso opcional. O selo pretende distinguir produtos cuja composição seja originária majoritariamente da agricultura familiar e empreendimentos, como cooperativas e associações, que promovem a inclusão econômica e social dos agricultores, com geração de empregos e renda no campo (MDA, 2012). Assim, sua missão está ligada a ideais de sustentabilidade, responsabilidade social e ambiental, valorização cultural e desenvolvimento local. Segundo a Secretaria de Agricultura Familiar, até 21 de novembro de 2012 haviam sido publicadas 600 permissões de uso do Selo da Agricultura Familiar, beneficiando cerca de 81.250 agricultores familiares, com potencial de aplicação a 5.537 produtos. $^{\mathrm{c}}$

A promoção de alimentos sustentáveis pelo governo federal ganhou novo reforço com a campanha Brasil Orgânico e Sustentável, lançada como parte das ações envolvendo a Copa Mundial de Futebol de 2014. Uma logomarca foi criada para identificar estabelecimentos que vendem produtos com essas características (BRASIL RURAL CONTEMPORÂNEO, 2012).

Esses selos oficiais apresentados até aqui têm caráter positivo, ou seja, procuram mostrar o que os alimentos selados têm de bom e incentivar seu consumo, com uma preocupação bastante voltada ao desenvolvimento da agricultura nacional e do País e também associada à saúde da população. Mas a legislação também prevê a identificação de características que podem ser consideradas negativas pelo consumidor. A afirmação "contém glúten”, por exemplo, destina-se a alertar pessoas com doença celíaca e outras condições sensíveis ao glúten da presença do componente, que apresenta riscos à saúde dessas pessoas (ANVISA, 2002a).

Outro exemplo de "rotulagem negativa" é o triângulo amarelo com um T maiúsculo dentro, definido pela Portaria 2.658, de dezembro de 2003, do Ministério da Justiça (MJ, 2003), para identificar alimentos que contenham ingrediente geneticamente modificado. Segundo o Decreto 4.680, de abril de 2003 (BRASIL, 2003), é direito do consumidor o acesso à informação sobre a participação de organismos geneticamente modificados (OGM) na produção de alimentos e ingredientes alimentares destinados ao consumo humano ou animal.

\footnotetext{
${ }^{\mathrm{c}}$ Informação fornecida à pesquisadora via e-mail em 21/12/2012.
} 
O decreto obriga a inclusão de aviso ["(nome do produto) transgênico", "contém (nome do ingrediente ou ingredientes) transgênico(s)" ou "produto produzido a partir de (nome do produto) transgênico"] e do triângulo amarelo no rótulo de qualquer produto alimentício com $1 \%$ ou mais de OGM em sua composição, seja o produto embalado, vendido a granel ou in natura. $\mathrm{O}$ decreto diz ainda que o consumidor deve "ser informado sobre a espécie doadora do gene no local reservado para a identificação dos ingredientes". Produtos com menos de 1\% de OGM na composição podem rotular com a alegação "livre de transgênicos" (BRASIL, 2003; FURNIVAL \& PINHEIRO, 2009).

A rotulagem dos transgênicos é defendida por alguns com base no Princípio da Precaução, consolidado na Alemanha nos anos 1970 em resposta à poluição industrial. Na década de 1990, Estados Unidos o interpretaram da seguinte forma: "É melhor ser grosseiramente certo no tempo devido, tendo em mente as consequências de estar sendo errado do que ser completamente errado muito tarde". No Brasil, o Princípio da Precaução foi consolidado como princípio 15 da Agenda 21 em 1992, tendo como finalidade proteger o meio ambiente diante do perigo grave ou irreversível. Ele significa que, diante da ausência da certeza científica, a existência do risco de um agravo demanda a implantação de medidas que possam prevenir este agravo (RIBEIRO \& MARIN, 2012).

$\mathrm{O}$ argumento em favor da rotulagem de transgênicos visa não somente à proteção da saúde dos consumidores, com base no princípio da precaução (FASE, 2012), mas também à proteção à biodiversidade (MACEDO \& ARAÚJO, 2012), à economia e ao agricultor (IDEC, 1996-2013), e por isso é considerada como uma conquista do consumidor. No entanto, nem todos concordam com a rotulagem de alimentos com OGM tal como a lei obriga hoje, já que existem interesses econômicos em jogo. O projeto de lei PL 4148/2008, de Luis Carlos Heinze, ${ }^{\text {de }}$ por

\footnotetext{
${ }^{d}$ Heinze LC. Projeto de Lei 4.148/2008. Altera e acresce dispositivos à Lei no ${ }^{\circ} 11.105$, de 24 de março de 2005. Disponível em: http://www.camara.gov.br/proposicoesWeb/prop_mostrarintegra?codteor $=605180 \&$ filename $=\mathrm{PL}+4$ $148 / 2008$

${ }^{\mathrm{e}}$ A página do deputado LC Heinze no site da Câmara diz que ele é proprietário rural. [acesso em 20 dez 2012]. Disponível em: http://www.camara.gov.br/internet/deputado/Dep_Detalhe.asp?id=523066
} 
exemplo, propõe uma alteração na Lei 11.105 que isentaria os produtores de rastrear a presença de OGM em sua produção, basearia a rotulagem no princípio da "detectabilidade" e eliminaria o triângulo amarelo, por entender que este associa os produtos a situação de perigo e não acrescenta informação.

A discussão foca em dois aspectos fundamentais de toda informação sobre alimentos destinada ao consumidor: a) o direito a informação clara e útil, que faça diferença na tomada de decisão, na saúde das pessoas e na sustentabilidade, e b) a responsabilidade atribuída ao consumidor de decidir o que é bom e o que não é. Em grande medida, e um bom exemplo são os transgênicos, a rotulagem tem sido usada para "deixar o consumidor decidir" enquanto não existe consenso científico nem político quanto ao que deve ser permitido ou proibido. Mas no que toca aos transgênicos, segundo COSTA \& MARIN (2011), "apesar de ser um assunto de alta repercussão em todo o mundo, a informação aos consumidores, principais interessados no assunto, parece ser mínima”.

Há que considerar ainda a harmonização com o Mercosul. Há pouca informação disponível sobre o funcionamento do processo decisório sobre rotulagem no âmbito do Mercosul. O site da Anvisa informa que o Mercosul é organizado institucionalmente na forma de subgrupos de trabalho e que sua participação se concentra em dois deles: o de regulamentos técnicos e o de saúde. Dentro do subgrupo de regulamentos técnicos (SGT3), que tem coordenação geral do Inmetro, há cinco comissões, entre as quais a de alimentos. A Comissão de Alimentos é coordenada pelo Mapa (coordenação titular) e pela Anvisa (coordenação alterna) (Anvisa, s/d - a). O site informa ainda que as áreas técnicas da Anvisa sempre participam da elaboração dos documentos que servirão de base para a negociação com os demais Estados Partes do Mercosul (ANVISA, s/d - b).

Segundo informação recebida da Anvisa por e-mail em 21/7/2014, participam da Comissão de Alimentos do SGT3 os Ministérios da Saúde, da Agricultura, da Justiça, do Desenvolvimento Social e Combate à Fome, entre outros. Foi informado também que atualmente na Comissão está sendo feita uma revisão do regulamento técnico de Rotulagem Geral de alimentos (RDC 259/2002). 
Sobre a atuação do SGT3, os sites do Inmetro e do Mapa não acrescentam muita informação.

Em junho de 2014, a Portaria 949 da Anvisa instituiu um Grupo de Trabalho destinado a auxiliar na elaboração de propostas regulatórias relacionadas à rotulagem nutricional, composto por representantes do governo, da sociedade civil, da academia e da indústria, coordenado pela Gerência Geral de Alimentos da Anvisa (ANVISA, 2014). Entre as entidades convidadas estão o Consea, a Secretaria Nacional do Consumidor (SENACON/MJ), o Mapa, o Ministério do Desenvolvimento Social e Combate à Fome (MDS), o Idec e a Associação Brasileira de Defesa do Consumidor (Proteste). Esta poderá ser uma oportunidade para buscar uma maior integração entre as instâncias decisórias e seus objetivos no aprimoramento na legislação de rotulagem, se o foco na rotulagem nutricional não perpetuar o nutricionismo na discussão. Será preciso aguardar os primeiros resultados. 


\subsection{A COMUNICAÇÃO VIA RÓTULOS}

Este trabalho se propõe a estudar o potencial comunicativo das embalagens de alimentos na promoção da alimentação saudável. Neste capítulo, são exploradas as bases teóricas para o estudo da comunicação.

Conforme será discutido mais adiante, alguns estudos sobre a rotulagem se baseiam no modelo informacional de comunicação. Nesse modelo, parte-se da premissa de que a comunicação acontece quando informações são codificadas por um emissor, transmitidas por um canal e decodificadas por um polo receptor (TRINDADE, 2007). Aplicado à rotulagem de alimentos, o modelo indicaria, por exemplo, que o consumidor, ao ler o rótulo, decodifica a mensagem emitida pelo fabricante do produto. Mas este não será o modelo adotado neste trabalho, pelas razões apresentadas a seguir.

Ao analisar os métodos adotados em estudos sobre a mídia, MARTÍNBARBERO (2009) recomenda que o pesquisador não caia na armadilha de reduzir a comunicação à transmissão de informação, como se emissor e receptor fossem instâncias homólogas situadas no mesmo plano de um circuito, entre as quais circula a mensagem. E questiona a suposição de que o máximo da comunicação funcione sobre o máximo da informação. Ele diz que

\footnotetext{
a delimitação operada pelo modelo informacional deixa de fora coisas demais. Não somente a questão do sentido, mas também a do poder. Fica de fora toda a gama de perguntas que vêm da informação como processo de comportamento coletivo. Fica de fora o conflito de interesses em jogo na luta por produzir, acumular ou veicular informações e, por conseguinte, os problemas da desinformação e do controle. Ao deixar de fora da análise as condições sociais de produção do sentido, o modelo informal (sic) elimina a análise das lutas pela hegemonia, isto é, pelo discurso que "articula" sentido de uma sociedade. (MARTÍN-BARBERO, 2009, p. 283)
}

Segundo CHARAUDEAU (2008), o ato de comunicação é um dispositivo composto por quatro elementos: 1) a situação de comunicação, "que constitui o enquadre ao mesmo tempo fisico e mental no qual se acham os parceiros da troca linguageira, os quais são determinados por uma identidade (psicológica e social) e 
ligados por um contrato de comunicação"; 2) os modos de organização do discurso (descritivo, argumentativo, narrativo); 3) a língua; e 4) o texto, “que representa o material do ato de comunicação e que resulta de escolhas conscientes (ou inconscientes) feitas pelo sujeito falante dentre as categorias de língua e os Modos e organização do discurso, em função das restrições impostas pela Situação" (p.68).

CHARAUDEAU (2008) distingue "situação" de comunicação de "contexto". Situação refere-se ao ambiente físico e social do ato de comunicação; contexto diz respeito ao ambiente textual de uma palavra ou sequência de palavras. Assim, o contexto é interno ao ato de linguagem e situação, externa (p. 69).

Para CHARAUDEAU (2008), comunicar é proceder uma encenação. O autor usa mesmo a encenação teatral como exemplo. Tudo que participa da cena no palco - o cenário, a luz, o figurino, os efeitos sonoros, a música, os atores, o narrador, as falas - visa a produzir efeitos de sentido para um público idealizado pelo autor/diretor (p. 68). E "toda e qualquer forma de comunicação traz em seu discurso marcas dos elementos constitutivos de seu processo" (TRINDADE, 2007).

Se pensamos a comunicação via rótulos de alimentos por essa perspectiva, podemos entendê-la como uma encenação em que os consumidores formam a plateia e toda a atuação das marcas de alimentos, dos órgãos reguladores, das entidades certificadoras e demais atores encontrados em cima desse "palco" constituem o enunciador. A análise desse processo de comunicação deverá ser capaz de perceber as marcas dos elementos que o constituem e, a partir delas, rastrear o percurso da produção e da recepção das mensagens.

\section{Análise do discurso}

A análise do discurso é usada em estudos de comunicação com a finalidade identificar as marcas ideológicas na emissão e na recepção de mensagens. A análise do discurso usualmente aplicada a estudos de comunicação difere daquela 
normalmente utilizada em estudos da área de saúde pública. Enquanto estes tendem a se debruçar sobre a fala espontânea de usuários ou profissionais de serviços de saúde, aqueles se ocupam dos significados intencionais na comunicação de massa.

A definição do que é análise do discurso não é algo fechado ou definitivo, pois "o fechamento significaria uma contradição em relação aos termos que a postulam" (BRAIT, 2008, p. 10). "Não há categorias a priori, aplicáveis de forma mecânica a textos e discursos, com a finalidade de compreender formas de produção de sentido num dado discurso, numa dada obra, num dado texto", esclarece (p. 14). Seria possível apenas "explicitar seu embasamento constitutivo, ou seja, a indissolúvel relação existente entre a língua, linguagens, história e sujeitos" (p.10). Os primeiros passos na concepção da teoria teriam sido dados pelo russo Bakhtin, citado por BRAIT (2008, p. 11), que definiu "discurso" como "a língua em sua integridade concreta e viva e não a língua como objeto específico da Linguística". Bakhtin não abandona a Linguística, mas vai além dela.

Segundo GREGOLIN (1995), a história da análise do discurso já dura dois mil anos, com início na Retórica grega, e ainda é um campo de estudos em formação com fronteiras ainda não claramente delimitadas. Até mesmo a definição de discurso varia de um autor para outro. Para esclarecer do que se trata, ela começa distinguindo discurso de texto a partir da semiótica de Algirdas Julien Greimas (1917-1992) e seu percurso gerativo de sentido.

Segundo a proposta greimasiana, todo texto trata de uma oposição entre duas abstrações, como por exemplo o capitalismo versus o socialismo, o que corresponde ao seu nível fundamental. Mas há inúmeras formas de tratar desse tema, o que dá origem a inúmeras narrativas possíveis para esses mesmos valores fundamentais, sendo que, conforme o sujeito da narrativa, tais valores podem ser considerados eufóricos (positivos, bem-vindos) ou disfóricos (negativos). Toda narrativa, na proposta greimasiana, começa no ponto em que um sujeito é estimulado a realizar uma transformação e termina no julgamento de seu desempenho. Assim, as narrativas têm quatro etapas, que podem não estar todas explicitadas no texto: a manipulação, a competência, a performance e a sanção. $O$ ponto de vista de onde será tecida a narrativa e as relações que busca estabelecer 
com o contexto correspondem ao nível discursivo do texto (FIORIN, 1989; GREGOLIN, 1995; TRINDADE, 2009b).

Suponhamos que dois alunos sejam incumbidos de escrever sobre as diferenças entre o socialismo e o capitalismo, citando exemplos concretos. Um deles usa os fatos para constatar o fracasso do socialismo e reafirmar que o capitalismo é o único regime possível para a paz no mundo, enquanto o outro texto elenca algumas das consequências mais nefastas do avanço capitalista no século $\mathrm{XX}$. No primeiro texto, o capitalismo é eufórico; no segundo, disfórico. O primeiro traz em si um discurso pró-capitalista e antissocialista; o segundo, o contrário.

Assim, GREGOLIN (1995) define discurso como "um dos patamares do percurso de geração de sentido de um texto, o lugar onde se manifesta o sujeito da enunciação e onde se pode recuperar as relações entre o texto e o contexto sóciohistórico que o produziu". Ou ainda, "um suporte abstrato que sustenta os vários textos (concretos) que circulam em uma sociedade". A Análise do Discurso (AD) procura colocar em relação o campo da expressão (a língua, a linguagem, área de estudo da Linguística) e o campo da sociedade, a partir da história e das ideologias. $\mathrm{A} \mathrm{AD}$ é um método que permite analisar internamente o que o texto diz e como ele diz e externamente por que diz o que diz (GREGOLIN, 1995). Sobre a ideologia, diz a autora:

\begin{abstract}
A "ideologia" é um conjunto de representações dominantes em uma determinada classe dentro da sociedade. Como existem várias classes, várias ideologias estão permanentemente em confronto na sociedade. A ideologia é, pois, a visão de mundo de determinada classe, a maneira como ela representa a ordem social. Assim, a linguagem é determinada em última instância pela ideologia, pois não há uma relação direta entre as representações e a língua (GREGOLIN, 1995, p. 17).
\end{abstract}

Paralelamente à obra de Greimas, nasce na França dos anos 1960 o que ficaria conhecido como a escola francesa da análise do discurso, constituída pela relação entre a linguística, o marxismo e a psicanálise, cujo maior expoente foi o filósofo Michel Pêcheux. A AD francesa se distinguiria da anglo-saxã, entre outros fatores, por debruçar-se mais sobre textos escritos a partir da linguística do que sobre a conversação oral com base na antropologia (MAINGUENEAU, 1993, p. 16). Pêcheux, citado por ORLANDI (2012a, p. 19; 2012b), teria definido discurso como "efeito de sentido entre locutores" (ORLANDI, 2012b, p. 37) e análise 
discursiva como análise da determinação histórica dos processos de significação (ORLANDI, 2012b, p.129).

Dominique Maingueneau traz uma nova abordagem para as oposições fundamentais das narrativas. Ele adota o termo 'campo discursivo' para designar o conjunto de formações discursivas (ou posicionamentos discursivos) que atuam em relação de concorrência, delimitando-se reciprocamente. Segundo o autor, o campo discursivo é um jogo de equilíbrio instável que pode ser reconfigurado sob a influência de mudanças na conjuntura em que ele ocorre (MAINGUENEAU, 1989, p. 116-7).

O termo 'formação discursiva' designa "todo conjunto de enunciados sóciohistoricamente circunscrito que pode relacionar-se a uma identidade enunciativa" (CHARAUDEAU \& MAINGUENEAU, 2012, p. 241-2). São “diferentes regiões que recortam o interdiscurso (...) e que refletem as diferenças ideológicas, o modo como as posições dos sujeitos, seus lugares sociais aí representados, constituem sentidos diferentes" (ORLANDI, 2007). As formações ou posicionamentos discursivos servem à instauração e à conservação de identidades enunciativas (CHARAUDEAU \& MAINGUENEAU, 2012, p. 392). Por meio da escolha dos termos e de como irá usá-los, um locutor indica como se situa num espaço conflituoso. Por exemplo, se usa termos técnicos e um tom didático, pode pretender posicionar-se como especialista. Se usa termos mais emocionais e um tom argumentativo, seu posicionamento pode ser de político ou ativista.

A relação do texto com seu contexto é um aspecto fundamental da $\mathrm{AD}$, que precisa entender a relação do texto com a situação que o criou. Quem são, onde e em que época vivem os dois estudantes com visões opostas sobre o socialismo? Que interesses têm eles na defesa de um regime em detrimento do outro? Que condições de vida os levaram a pontos de vista tão conflitantes sobre o mesmo tema?

Um importante princípio discursivo é que "não há discurso sem sujeito e não há sujeito sem ideologia” (ORLANDI, 2012b, p. 153). E as ideologias, segundo BOURDIEU (2010), "servem interesses particulares que tendem a apresentar como interesses universais, comuns ao conjunto do grupo" (p. 10). 
As ideologias devem a sua estrutura e as funções mais específicas às condições sociais da sua produção e da sua circulação, quer dizer, às funções que elas cumprem, em primeiro lugar, para os especialistas em concorrência pelo monopólio da competência considerada (religiosa, artística, etc.) e, em segundo lugar, por acréscimo, para os nãoespecialistas. (BOURDIEU, 2010, p. 13).

Segundo MAINGUENEAU (2002), o discurso é uma forma de ação que visa modificar uma situação; constrói-se em função de uma finalidade, portanto deve dirigir-se para algum lugar (p. 53). "O discurso só é discurso enquanto remete a um sujeito, um EU, que se coloca como fonte de referências pessoais, temporais, espaciais e, ao mesmo tempo, indica que atitude está tomando em relação àquilo que diz e em relação a seu co-enunciador" (p. 55).

Numa sociedade, diversas formações ideológicas estão disponíveis, dando origem a formações discursivas correspondentes, ou seja, "o que se pode e se deve dizer em determinada época, em determinada sociedade", conforme Pêcheux, citado por GREGOLIN (1995). “Os valores ideológicos de uma formação social estão representados no discurso por uma série de formações imaginárias, que designam o lugar que o destinador e o destinatário se atribuem mutuamente" (Pêcheux, 1990, p.18, citado por Gregolin). Os processos discursivos surgem, portanto, das fontes de produção de sentidos, não da linguagem. "A língua é o lugar material onde se realizam os "efeitos de sentido"" (GREGOLIN, 1995).

Isso significa que os sujeitos nem sempre são senhores dos sentidos que geram, já que estão inseridos em um contexto historicamente constituído.

\begin{abstract}
Não sabemos como os sentidos se constituem em nós mesmos. Nossa memória discursiva é estruturada pelo esquecimento. Já nem lembramos quando e como a palavra liberdade começou a fazer sentido para nós, ou para a sociedade na qual vivemos. Como diz M. Pêcheux (1990), "é por filiação a uma complexa rede de sentidos e não por aprendizagem que os sentidos se constituem" (ORLANDI, 2012b, p. 156).
\end{abstract}

A grande diferença entre a análise de discurso e a análise de conteúdo é que, para a $\mathrm{AD}$, a linguagem não é transparente; as palavras geram sentidos diferentes conforme suas condições de uso. Um ótimo exemplo é a palavra 'salário', que pode gerar sentidos diversos se usada pelo/para o patrão ou pelo/para o operário (ORLANDI, 2012a, p. 17; 2012b, p. 157-8). “O lugar a partir do qual fala o sujeito é constitutivo do que ele diz" (ORLANDI, 2012a, p. 39). 
À AD interessa não meramente interpretar o texto, mas compreender as condições de produção do texto. Portanto a $\mathrm{AD}$ não se fixa apenas no texto como plano de expressão e de conteúdo, mas deve debruçar-se com a mesma atenção sobre os mecanismos geradores de sentido, as condicionantes históricas produtoras do discurso como objeto cultural e a relação dialógica com outros textos. Deve analisar não apenas o enunciado, mas a enunciação, o que inclui "os recursos de persuasão utilizados para criar a 'verdade' do texto (relação enunciador/enunciatário) e os temas e figuras utilizados". "Compreender é saber como um objeto simbólico produz sentidos." (ORLANDI, 2012a, p. 26). Assim, a $\mathrm{AD}$ busca entender "como se constrói o sentido de um texto e como esse texto se articula com a história e a sociedade que o produziu". (GREGOLIN, 1995).

A AD vai tratar então de rastrear as marcas deixadas no texto pelo enunciador (sendo o principal enunciador a marca/fabricante do "cereal", no caso do corpus de análise deste trabalho) e como ele quer que o enunciatário as interprete. São muitas as formas de marcar o texto. Há estratégias discursivas para dizer e para não dizer, como a implicitação baseada em pressupostos ou subentendidos; a citação direta ou indireta; a figurativização, em que os temas são concretizados em figuras reconhecíveis pelo enunciatário e que lhes atribuam traços de revestimento sensorial (GREGOLIN, 1995).

Entenda-se como "texto" no corpus deste trabalho não apenas frases impressas na embalagem, mas também as imagens, as ilustrações, os selos, os números e quaisquer elementos comunicacionais que signifiquem alguma coisa.

Outro aspecto importante que a $\mathrm{AD}$ deve considerar é o interdiscurso. "O interdiscurso é todo o conjunto de formulações feitas e já esquecidas que determinam o que dizemos. Para que minhas palavras façam sentido é preciso que elas já façam sentido" (ORLANDI, 2012a, p. 33). Em outras palavras, interdiscurso é memória afetada pelo esquecimento, é a memória constitutiva, discursiva, anterior ao discurso presente. $\mathrm{O}$ esquecimento ideológico é a ilusão de que nossas ideias e os sentidos nascem em nós em vez de serem determinados pela maneira como nos inscrevemos na língua e na história (ORLANDI, 2012a, p. 35). Sempre há um interdiscurso, pois "um discurso nunca começa nele mesmo" (ORLANDI, 2012b, p. 161). 
Conforme será discutido mais adiante, o próprio uso da designação "cereal matinal" na identificação de uma categoria de produtos alimentícios que têm determinadas características, são destinados a um determinado modo de consumo e comercializados num determinado contexto, revela um discurso que tem uma origem histórica que pode ser resgatada. A AD será capaz de desconstruir a memória esquecida da origem do uso dessa designação, desnaturalizá-lo, e explicitar a ideologia que as embalagens de produtos chamados de "cereais matinais" legitimam.

A forma de presença dessa memória varia. No interdiscurso há as duas possibilidades: a do mesmo e a do diferente. Ou seja, na presença dessa memória, os sentidos se estabilizam ou se movimentam. Se o movimento será de estabilização ou transformação vai depender do gesto de interpretação produzido e da posição do sujeito em sua filiação ao interdiscurso (ORLANDI, 2012b, p. 171).

"Não há dizer que para fazer sentido não se inscreva na memória. Não há dizer que não se faça a partir da repetição. No entanto, na repetição histórica, há deslocamento, deriva, transferência, efeito metafórico. E o efeito metafórico é retomada e esquecimento, deslize para outro lugar de sentido, novo gesto de interpretação" (idem, p. 173).

A $\mathrm{AD}$ deve pôr em relação o dito e o não dito, o que é dito em um lugar e o que é dito em outro lugar, o que é dito de um modo e o que é dito de outro modo. (ORLANDI, 2012a, p. 59). Deve explicitar os processos de identificação, os gestos de interpretação, descrever a relação do sujeito com a memória. (p. 60). É disso que se trata.

\section{Estudos sobre publicidade de alimentos}

Os discursos da indústria de alimentos nos meios de comunicação de massa são estudados há várias décadas. Roland Barthes foi pioneiro na análise de como a publicidade de alimentos participava da geração de sentidos no comportamento alimentar das sociedades. Conforme a leitura de TRINDADE (2009b), ele estava interessado no papel da publicidade na construção de significados e conceitos para 
novos costumes alimentares, partindo do pressuposto de que os significados culturais da alimentação não provêm dos alimentos conforme eles são retirados da natureza, mas de sua transformação pela situação social de uso.

Para BARTHES (1997), os alimentos constituem um sistema de comunicação, um corpo de imagens, um protocolo de usos, situações e comportamentos, e seu estudo deve considerar não apenas estatísticas e nutrientes, mas também a observação direta da economia, das técnicas, dos usos e da propaganda, além da observação indireta da vida mental da sociedade. "Quando compra um item alimentar, o consome ou o serve, o homem moderno não manipula um simples objeto de modo puramente transitivo; esse item alimentar se soma a e transmite uma situação; ele constitui uma informação; ele significa” (p. 21).

Construindo as bases da análise semiótica da publicidade, Barthes examinou como marcas de produtos e serviços alimentares, por meio de um espetáculo estético, tratavam o alimento como mercadoria capaz de conferir status e identidade a quem o consome, da mesma forma como a indústria da moda transformava peças de vestuário em signo de distinção. Assim, operados coletivamente pela publicidade, os alimentos adquiririam uma dimensão simbólica que poderia ultrapassar a dimensão nutritiva, tornando-se situação (BARTHES, 1997). Esse trabalho de Barthes teria inspirado os modelos de análise semiótica da comunicação publicitária desenvolvidos por autores como Jaques Duran, Pèninou, Umberto Eco e Martine Joly (TRINDADE, 2009b).

Greimas não estudou inicialmente a publicidade, mas seu percurso gerativo de sentido contribuiu grandemente para os estudos da área.

\footnotetext{
O percurso gerativo de sentido greimasiano demonstra que os sentidos se articulam originalmente em níveis de significação que vão de categorias mais abstratas para categorias mais concretas, a saber: o nível fundamental; o nível narrativo e o nível discursivo. Hoje se considera também um quarto nível, o da manifestação textual, que incorpora a expressividade dos discursos para a análise, já que os três níveis anteriores pertencem ao universo do conteúdo, sendo este nível um campo novo que passa ser explorado nos domínios da semiótica visual a partir da década de 1980 (TRINDADE, 2009b, p 35).
}

Podemos dizer que o percurso narrativo do modelo de Greimas aplicado à publicidade começa na mensagem que estimula o sujeito consumidor a sair em busca da satisfação de um desejo (manipulação). O sujeito então, em sua jornada, 
adquire competências para conquistar seu objeto de valor ou desejo, até estar pronto para realizar o desejo (performance), o que culmina na sanção positiva - ou negativa, no caso de performance mal sucedida. O percurso seria, assim, o caminho para o reconhecimento social simbólico por meio do consumo (TRINDADE, 2009b, p. 37).

Jean-Marie Floch, discípulo de Greimas e também citado por TRINDADE (2009b), também aplicou a semiótica ao estudo da publicidade. Sua principal contribuição foi o desenvolvimento do chamado quadrado semiótico de Floch, que define quatro perfis de consumidores: o prático, o utópico, o lúdico e o crítico, que correspondem respectivamente a quatro ideologias das manifestações publicitárias: a referencial, a mítica, a oblíqua e a substancial. Semprini, conforme TRINDADE (2009b), acrescentou que as marcas podem adotar um posicionamento híbrido, combinando essas categorias, em função dos interesses do mercado. TRINDADE (2009b, p. 37) afirma que esse modelo pode ser aplicado à publicidade de alimentos e cita o exemplo do preparo de uma sopa, dado por Greimas para ilustrar o percurso narrativo de geração de sentido.

\begin{abstract}
Ao cruzarmos a narrativa do consumo dos indivíduos com as narrativas do consumo alimentar, entendemos um segundo fundamento sobre as significações das publicidades de alimentos, que demonstraremos mais à frente, que se refere à alimentação como uma competência para a existência, sobrevivência, um estilo de vida que se estabelece de acordo com a identidade cultural e com a condição socioeconômica que o indivíduo se insere. Isso nos leva a pensar que as narrativas publicitárias dos alimentos transitam, principalmente, entre as fases da manipulação, apresentando o produto/marca de alimentos como uma competência narrativa para se entrar em conjunção com o objeto de valor - viver a vida bem, com saúde, com charme, com requinte pelo comer bem ou com o glamour da gastronomia, por exemplo, pois o que o sujeito quer como objeto de valor não é necessariamente o produto em si, nem a sua nutrição pura e simples, mas sim os atributos da marca que a ele passam a ser atribuídos por meio do consumo. A marca dá as competências para o indivíduo ser ou parecer ser algo que é objeto de sua realização, status social, prazer e felicidade, por exemplo (TRINDADE, 2009b, p 38-39).
\end{abstract}

MAINGUENEAU (2002) diz que "a publicidade visa seduzir, para, em última instância, vender um produto. A determinação correta dessa finalidade é indispensável para que o destinatário possa ter um comportamento adequado ao gênero de discurso utilizado" (p. 66).

Em outro artigo, TRINDADE (2009a) diz que "que o objetivo final da publicidade é construir vínculos de sentido que interliguem o anunciante e o bem 
anunciado ao receptor, possível consumidor" e que, embora nem sempre interfira diretamente na tomada de decisão de compra,

\begin{abstract}
a publicidade pode repercutir na perspectiva de usos e consumos a partir do estímulo à compra de mercadorias semelhantes, cópias, e não necessariamente o bem anunciado, ou simplesmente se restringir ao consumo psíquico da mensagem anunciada, na formação das aspirações e modelos de vida ideais, sem desencadear o processo de compra, mas garantindo a adesão ao modelo de vida proposto (TRINDADE, 2009a, p. 125).
\end{abstract}

São dois os tipos de vínculos de sentido apresentados pelo autor. O vínculo de sentido sígnico-material é "o elo que se pode estabelecer entre as marcas/produtos e serviços com seus mundos imaginados, publicizados, e o mundo vivido, na possibilidade de construir um sentido comum ou cronotrópico entre o tempo e o espaço da marca e o tempo e o espaço dos consumidores/receptores" (TRINDADE, 2012. p. 78-79). Seria por meio desse vínculo e da identificação gerada com o consumidor/receptor que as marcas influenciariam direta e indiretamente o consumo. Já o vínculo sígnico/simbólico não se reverte necessariamente na compra de uma mercadoria ou serviço, mas implica na incorporação de um estilo de vida, tomado pelo consumidor/receptor como forma de manifestação de seus hábitos, "o que, por sua vez, reforça seus valores e visões de mundo" (TRINDADE, 2012, p. 79).

A aplicação proposta por TRINDADE (2009a) para a teoria dos vínculos de sentido é a de estudos sobre a recepção ou consumo da mensagem publicitária, em que a etnografia se uniria à semiótica para tentar entender como as pessoas absorvem signos e valores da publicidade em sua vida cotidiana. $\mathrm{O}$ autor diz ainda que "os vínculos de sentidos se caracterizam por situações interativas codificadas, referentes às várias possibilidades de atuação dos sujeitos receptoresconsumidores", e que "ganham nuanças de sentidos pelas representações de seus sujeitos (tipos de leituras e recepção e rituais de consumo) em seus respectivos tempos e espaços vividos" (TRINDADE, 2009a, p. 135).

O consumo, incluindo o da mensagem publicitária, é visto por MARTÍNBARBERO (2009) não como uma atitude passiva, mas tão produtiva quando a produção da mensagem. "O receptor, portanto, não é um simples decodificador daquilo que o emissor depositou na mensagem, mas também um produtor" (p. 289). 
Ele cita García-Canclini, segundo o qual "não se trata apenas de medir a distância entre as mensagens e seus efeitos, e sim construir uma análise integral do consumo, entendido como o conjunto de processos sociais de apropriação dos produtos" (MARTÍN-BARBERO, 2009, p. 292). E acrescenta:

"O consumo não é apenas reprodução de forças, mas também produção
de sentidos: lugar de uma luta que não se restringe à posse dos objetos,
pois passa ainda mais decisivamente pelos usos que lhe dão forma
social e nos quais se inscrevem demandas e dispositivos de ação
provenientes de diversas competências culturais" (idem).

LLANO LINARES \& TRINDADE (2011) descrevem como os significados podem ser transferidos dos alimentos para os consumidores a partir de uma adaptação do modelo de movimento de significados desenvolvido pelo antropólogo americano Grant McCracken, inicialmente aplicado ao universo da moda. No trabalho originalmente publicado em 1986 no Journal of Consumer Research como o título Culture and consumption: a theoretical account of the structure and movement of the culural meaning of consumer goods, citado por LLANO LINARES \& TRINDADE (2011), McCracken diz que os bens de consumo possuem um significado dinâmico, para além de seu valor utilitário e comercial, que flui constantemente pela ação de agentes como produtores culturais, publicitários, designers, cientistas etc. $\mathrm{O}$ percurso do movimento de significados teria as seguintes etapas: tem origem no mundo culturalmente constituído, é transferido deste para o bem de consumo e deste para o consumidor individual. (MCCRACKEN, 2003, p.100). Adaptado à alimentação, o percurso seria o apresentado na Figura 11.

O mundo culturalmente constituído é o lugar da experiência cotidiana, composto de regras, crenças e pressupostos culturais que moldam como o mundo deve ser visto. Segundo MCCRACKEN (2003), os bens são uma instância da cultura material porque permitem fazer uma discriminação palpável das categorias culturais (p.104). Então, de acordo com a adaptação de LLANO LINARES \& TRINDADE (2011), a publicidade, juntamente com os nutricionistas, as instituições de saúde, os chefs ou cozinheiros, a mídia e os produtores de alimentos, atuaria nesse sistema como um instrumento de transferência de significado do mundo culturalmente constituído para os bens, pois representa o mundo cultural no 
formato de um anúncio e funde o bem anunciado a essa representação. Por meio dela, os bens antigos adquirem novos significados (MCCRACKEN, 2003, p. 109; LLANO LINARES \& TRINDADE, 2011).

Figura 11. Adaptação do modelo de movimento de significados de McCracken ao setor alimentar.

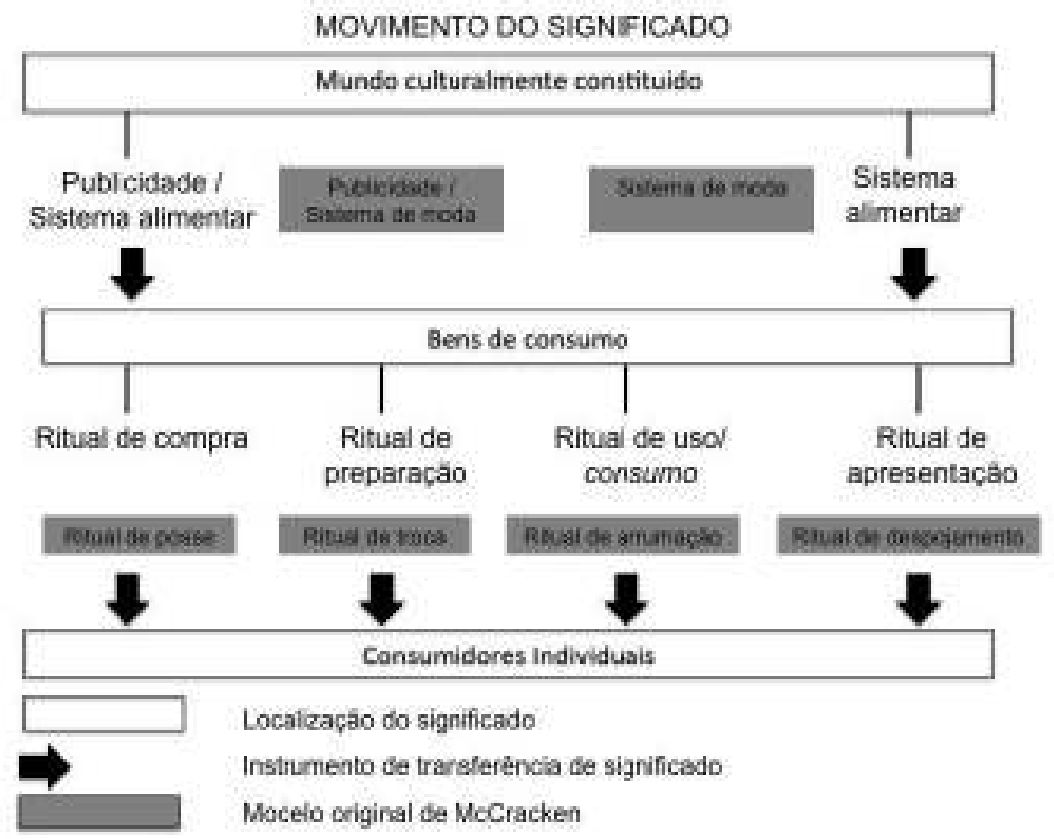

Extraído de: LLANO LINARES \& TRINDADE (2011), p. 50.

A transferência de significado do bem para o indivíduo se dá, segundo MCCRACKEN $(2003,2007)$, por meio de rituais. No caso da alimentação, trata-se dos rituais de compra, preparação, usos e apresentação. Como a alimentação é uma necessidade diária, o ato prático da compra se transforma em um ritual simbólico porque estabelece um processo regular de transferência de significados. "O espaço onde se realizam as compras de alimentos desempenha uma parte importante da construção destes rituais. De acordo com o tipo de espaço e sua evolução histórica, o consumidor estabelece diferentes significados e constrói diferenças simbólicas entre estes" (LLANO LINARES \& TRINDADE, 2011). Quer dizer, o próprio consumidor completa a transferência de significados. Esta depende da participação dele. 
Os rituais de preparação dizem respeito ao ato de seguir de receitas, temperar, combinar, misturar, cozinhar, transformar o alimento de cru em cozido, aquecer, esfriar, separar o podre do bom para consumo, opor o natural ao cultural e o elaborado ao não-elaborado. São rituais profundamente simbólicos, que modificam o significado dos alimentos, assim como o do ato de servir e de comer.

Entre os rituais de uso ou consumo podemos incluir os utensílios escolhidos, o lugar e o momento de comer, a posição à mesa, a ordem dos pratos, o tempo da refeição, a distribuição dos alimentos entre os comensais, a hierarquia, a vestimenta, o tom da conversa etc. Dos rituais de celebração fazem parte as festas, os pratos típicos, os ritos de passagem, as associações entre datas e crenças e o que se deve ou não se deve comer. Já os rituais de apresentação dizem respeito ao modo de servir os alimentos à mesa, à sedução gastronômica, à experiência sensorial da alimentação. O movimento dos significados se completa no consumidor. É ele, na construção constantemente atualizada de sua identidade individual, inserida em seu contexto cultural, quem define o significado que quer extrair dos bens (LLANO LINARES \& TRINDADE, 2011).

\section{Análise do discurso em rótulos}

Assim como a propaganda, a comunicação nas embalagens tem a função de estabelecer vínculos de sentido com o consumidor. Em muitos casos, a embalagem é o principal meio de comunicação da marca com seu público. Segundo MESTRINER (2001), "menos de 10\% dos produtos expostos em um supermercado têm apoio de uma propaganda. O restante se vale exclusivamente da embalagem para conquistar o consumidor" (p.18). Isso explicaria o fato de o design das embalagens incorporar elementos da linguagem de outras áreas e acompanharem a moda e as tendências culturais e sociais. "A grande força da embalagem está no fato de o marketing ser uma batalha de percepção e não de produtos. Nesse sentido, 
a embalagem tem o poder de fazer com que o produto seja percebido de uma certa maneira, agregando a ele novos valores e significados" (idem).

A emergência das embalagens como importante ponto de contato com os consumidores data do pós-guerra, com o surgimento dos supermercados. "A venda em sistema de autosserviço estimulou os produtos a conterem a informação necessária para concretizar a venda sem o auxílio de vendedores" (MESTRINER, 2001, p.13). Com o desenvolvimento das tecnologias fotográficas, as marcas passaram a caprichar nas imagens impressas nas embalagens, a fim de estimular o apetite do público. "O conceito de apetite appeal é um marco na construção da linguagem da embalagem, pois estabelece intencionalmente uma reação provocada no desejo do consumidor" (idem, p.16).

Assim, os métodos de análise da publicidade de alimentos são válidos também para estudar os rótulos. Eles podem contribuir para a formulação de novas propostas para melhorar a qualidade da produção e da recepção dos rótulos de alimentos.

Um exemplo é uma análise das embalagens da marca Mãe Terra que aplicou o modelo de McCracken e alguns princípios da semiótica peirceana (LIMA \& MIKLASEVICIUS, 2012). As autoras entendem que a marca estabelece um movimento de significado que parte de um mundo culturalmente constituído em que ideais de preservação do meio ambiente, alimentação mais natural e resgate de um estilo de vida mais ligado à natureza, é transferido para os produtos tradicionais da marca, que consistem basicamente de cereais integrais, e passa a compor a identidade do consumidor, que se vê como um cidadão consciente ao dar preferência a alimentos naturais, integrais e "verdes".

Uma das características particulares deste objeto de estudo é o seu contexto de leitura. Rótulos de alimentos são etiquetas impressas nas embalagens de alimentos e bebidas, principalmente processados industrialmente, que contêm um conjunto de informações e mensagens emitidas por diferentes sujeitos e direcionadas a um público-alvo coletivo e anônimo chamado aqui de consumidor.

O primeiro momento de contato do público com os rótulos é geralmente aquele em que o consumidor percorre o ponto de venda à procura de mercadorias para comprar. Nessa ocasião, na medida do porte do estabelecimento comercial, o 
consumidor terá contato simultâneo com uma infinidade de embalagens, todas criadas para atrair a atenção de seu público-alvo, todas comunicando alguma mensagem. E a arquitetura do estabelecimento organiza previamente esse contato, uma vez que agrupa geograficamente produtos para finalidades semelhantes.

Assim, a leitura de uma embalagem no ponto de venda não se dá apenas de acordo com o pretendido pela marca do produto, mas também de acordo com o pretendido pelo estabelecimento e com a cultura de consumo de cada categoria de produto. Como ressalta MESTRINER (2001),

\footnotetext{
"um produto nunca é visto isoladamente, mas sempre apresentado aos consumidores ao lado de seus concorrentes. O consumidor vê o produto dentro de sua categoria, no espaço destinado a ela nas lojas e supermercados. As categorias têm uma história e uma identidade visual própria que precisa ser considerada" (p.50).
}

O autor dá o exemplo dos molhos de tomate. Embalagens de molhos de tomate são historicamente identificadas pela cor vermelha do tomate. Um molho de tomate numa embalagem azul não seria facilmente identificado pelo consumidor como pertencente à mesma categoria de produto, pois estamos todos acostumados com a cor vermelha e é isso que esperamos encontrar no varejo.

Como fruto de uma teoria em construção, a AD não segue um protocolo único, universal, homogêneo. Embora a teoria seja retomada continuamente no processo de análise, não se trata apenas de aplicá-la. A análise envolve constante confronto, interrogação e garantia de não continuidade entre teoria e prática, pois a continuidade inviabilizaria a compreensão do funcionamento do discurso (ORLANDI, 2012b, p. 12). Ela pressupõe um dispositivo teórico e um dispositivo analítico, construído pelo analista a cada análise. Como diz ORLANDI (2012a), já que a leitura não é transparente, é preciso instrumentá-la, e a natureza do material significante é importante na maneira como construímos nosso dispositivo analítico. Materiais diferentes exigem modos de construção do dispositivo analítico diferentes (ORLANDI, 2012b).

$\mathrm{Na}$ construção desse dispositivo, é preciso considerar que, além das particularidades do perfil de cada marca e cada produto, todo rótulo de alimento traz em si um interdiscurso, uma anterioridade, que diz respeito à história da alimentação, à história da saúde e das recomendações nutricionais, à história do 
consumo de "cereais matinais" e à história da rotulagem de alimentos, entre outras histórias. "Um discurso nunca começa nele mesmo" (ORLANDI, 2012b, p. 161). Tudo que é dito numa embalagem e todo potencial de interpretação do que é dito vêm de um momento anterior em que foi dito e aceito que tais dizeres eram pertinentes para a rotulagem. Essa anterioridade deve fazer parte da análise.

A análise de discurso passa da superfície linguística para o objeto discursivo e deste para o processo discursivo, chegando à formação ideológica (ORLANDI, 2012a, p. 68-77). A tarefa do analista do discurso é interrogar o texto e explicitar os modos como ele pode ser interpretado no contexto discursivo e na situação específica em que será lido.

\begin{abstract}
Analisar um texto não é nem pretender dar conta apenas do ponto de vista do sujeito comunicante, nem ser obrigado a só poder dar conta do ponto de vista do sujeito interpretante. Deve-se, sim, dar conta dos possiveis interpretativos que surgem (ou se cristalizam) no ponto de encontro dos dois processos de produção e de interpretação. O sujeito analisante está em uma posição de coletor de pontos de vista interpretativos e, por meio da comparação, deve extrair constantes e variáveis do processo analisado (CHARAUDEAU, 2008, p. 63).
\end{abstract}

O processo discursivo é um sistema de relações de substituição, paráfrases (repetição), sinonímias etc. que funcionam entre elementos linguísticos significantes em uma formação discursiva dada (ORLANDI, 2012b, p. 135). A paráfrase (repetição) e a metáfora (uma palavra por outra) são os dois mecanismos fundamentais do funcionamento da linguagem, sendo que a metáfora é responsável pelos deslizamentos dos sentidos, pela deriva, pela transparência (idem, p. 154). Diz Pêcheux:

\begin{abstract}
todo enunciado é intrinsecamente suscetível de tornar-se outro, diferente de si mesmo, se deslocar discursivamente de seu sentido para derivar para um outro (...). Todo enunciado, toda sequência de enunciados é, pois, linguisticamente descritível como uma série (léxico-sintaticamente determinada) de pontos de deriva possíveis, oferecendo lugar a interpretação. É nesse espaço que pretende trabalhar a análise de discurso (PÊCHEUX, 1997, p. 53).
\end{abstract}

A análise do discurso procura evidenciar as condições de produção de discursos não apenas a partir do dito, mas também do não dito, pois para dizer uma coisa é preciso não dizer outras. Os não-ditos são silêncios constitutivos que delimitam o interdiscurso, deixando de fora sentidos indesejáveis. "O silenciamento é parte da experiência da identidade, pois é parte constitutiva do processo de 
identificação, é o que lhe dá espaço diferencial, condição de movimento" (ORLANDI, 2007). Os silenciamentos ou apagamentos são, portanto, estratégias de fortalecimento de discursos.

Um dos elementos fundamentais da análise é a identificação do ethos do enunciador. O conceito de ethos, oriundo da retórica e retrabalhado por Maingueneau, refere-se às propriedades que os oradores se atribuíam implicitamente, pelo modo de se expressar. É uma imagem construída de si que responde à necessidade de um sujeito de se fazer reconhecido e legitimado a expor determinado discurso. "O enunciador deve legitimar o seu dizer: em seu discurso, ele se atribui uma posição institucional e marca sua relação a um saber" (CHARAUDEAU \& MAINGUENEAU, 2012, p. 220). Para Roland Barthes, citado por MAINGUENEAU (2002), o ethos consiste nos "traços de caráter que o orador deve mostrar ao auditório (pouco importa sua sinceridade) para causar boa impressão: são os ares que assume ao se apresentar" (p. 98).

A noção de ethos desenvolvida por Maingueneau se afasta da retórica clássica ao considerá-lo presente em todas as manifestações discursivas. O ethos na AD se constitui em uma dimensão discursiva que faz parte da identidade de um posicionamento discursivo. Ele é parte constitutiva da cena de enunciação, com o mesmo estatuto que o vocabulário ou os modos de difusão que o enunciado implica por seu modo de existência.

$\mathrm{O}$ autor coloca que, ao enunciar, o sujeito se concede simbolicamente um certo lugar e simultaneamente atribui ao coenunciador um lugar complementar ao seu. $\mathrm{O}$ enunciador então pede ao coenunciador que se mantenha no lugar que lhe foi atribuído e reconheça que a figura que fala é exatamente aquela que fala do lugar onde se colocou. Um sujeito, ao enunciar, presume uma espécie de ritual social da linguagem, implícito, partilhado pelos interlocutores.

Os discursos procuram levar o coenunciador a identificar-se com a movimentação de um corpo investido de valores historicamente especificados, e é daí que vem o seu poder de persuasão. A qualidade do ethos remete à figura desse "fiador" que, ao dizer, dá a si mesmo uma identidade que seja compatível com o mundo que ele faz parecer surgir de seu enunciado. $O$ paradoxo constitutivo da enunciação é que o fiador deve legitimar sua maneira de dizer por meio do seu 
próprio enunciado. É por meio da construção da imagem de si que o enunciador legitima seu próprio dizer, construindo uma imagem calcada em valores historicamente aceitos, de acordo com uma situação dada (MAINGUENEAU, 2002, p. 99).

O papel dos rótulos na promoção da alimentação saudável está intimamente atrelado aos enunciadores que falam por meio deles e seus discursos. Convém conhecê-los. 


\section{OBJETIVOS}

O objetivo geral deste trabalho é entender por meio de quais conteúdos e linguagens se formam os discursos sobre alimentação saudável nos rótulos e analisar o potencial da comunicação via rótulos na promoção da alimentação saudável, tendo em vista os conceitos propostos na Política Nacional de Alimentação e Nutrição.

Parte-se da premissa de que o objetivo da saúde pública ao rotular alimentos é orientar o consumidor em suas escolhas visando à saúde e, em última instância, influenciar as práticas de consumo alimentar dos brasileiros em direção ao que a política alimentar considera mais saudável (MS, 2012, p. 31). Se os instrumentos oficiais adotados atualmente para orientar as escolhas alimentares do consumidor por meio da rotulagem são a informação nutricional obrigatória, a informação nutricional complementar, a lista de ingredientes, alguns selos e símbolos, podemos deduzir que a saúde pública espera que o consumidor seja capaz de extrair desses elementos informativos o conhecimento necessário para tomar decisões relevantes para sua saúde (e a de sua família, conforme o perfil do comprador) e para o equilíbrio do sistema alimentar no País.

É pertinente investigar, no entanto, se a ocorrência simultânea de diversos sujeitos emissores, linguagens, objetivos, critérios e momentos decisórios num mesmo rótulo resulta num fator complicador para o processo de comunicação com os consumidores, uma vez que os discursos resultantes dessa combinação podem ser concorrentes e até conflitantes, gerando efeitos de sentido diversos daqueles pretendidos pela saúde pública.

Os objetivos específicos do estudo são três: buscar na literatura científica sobre rotulagem de alimentos dados sobre o funcionamento da comunicação nos rótulos, com ênfase na rotulagem nutricional e nos ecorrótulos; fazer uma análise empírica do potencial comunicativo de rótulos de alimentos comercializados no Brasil, a fim de entender como a emissão de mensagens nas embalagens gera 
sentidos relacionados à alimentação saudável e sustentável; e elaborar propostas para o fortalecimento do discurso oficial na comunicação com os consumidores, via rotulagem de alimentos.

A revisão da literatura específica tem como propósitos obter um balanço da qualidade da comunicação nos rótulos em diversos países, fazer um levantamento dos tipos de estudos sobre rotulagem que vêm sendo realizados, identificar lacunas na pesquisa sobre o tema e elaborar perguntas para novos estudos.

Conhecer os significados gerados na enunciação nos rótulos e potencialmente transmitidos ao consumidor por meio dos rituais de consumo, bem como as linguagens usadas, deverá servir para entendermos os modos de presença dos discursos da saúde na vida social, incluindo espaços de comercialização, ambientes de usos e consumos. Esse entendimento nos permitirá distinguir quais significados e linguagens interessam à promoção da alimentação saudável.

A partir dos resultados das duas primeiras etapas, pretende-se elaborar propostas a serem testadas em novos estudos.

O objetivo final da pesquisa é contribuir com o aprofundamento dos conhecimentos no campo da comunicação e saúde, particularmente no que diz respeito ao papel da comunicação pública e de massa na promoção da alimentação saudável.

Espera-se que os dados apresentados justifiquem a criação de modelos experimentais de rótulos mais integrativos e tecnologicamente avançados, capazes de construir uma lógica midiatizadora de sentidos sintonizados com os objetivos da PNAN. 


\section{MÉTODOS}

Para atender ao primeiro objetivo específico deste trabalho, foi feita uma revisão da literatura científica sobre rotulagem de alimentos. A busca deu ênfase a estudos de emissão (produção das mensagens) e de recepção (o interesse, o uso e o entendimento das mensagens pelo consumidor), de qualquer país, publicados em português ou inglês a partir da segunda metade dos anos 1990, quando a rotulagem nutricional nos Estados Unidos já estava em uso, mas principalmente na última década.

Além do PubMed, foram usadas bases de dados interdisciplinares, como a CAB, o Google Acadêmico e o sistema de busca integrada do SIBI USP. A busca incluiu termos em português e principalmente em inglês tais como: food label, food labeling, food labelling, environmental, sustainability, sustainable, social responsibility, consumer information, consumer choices, ecolabel, food advertising, food marketing, health claim(s), health promotion, consumer (health) information, nutrition information, food information, nutrition claims, nutrition labels, nutrition labeling, nutrition policy, food policy, dietary guidelines, eco-labelling, sustainability labeling, sustainable consumption, sustainable agriculture, consumer empowerment, ethical consumer, organic food, corporate social responsibility, certification, nongovernmental organizations, citizen-consumers, consumer decision making, assymmetric/ missing information, front-of-pack label, nutrition rating system, discurso, linguagem, publicidade de alimentos, comunicação.

A escolha do método de estudo empírico do potencial da comunicação nos rótulos de alimentos como promotora da alimentação saudável, segundo objetivo do trabalho, partiu de duas premissas: 1) era necessário tratar os rótulos como meios de comunicação de massa; 2) a comunicação não é um sistema de transmissão linear de informação de um emissor a um conjunto de receptores, mas um processo mais complexo no qual a recepção interage com as condições sociais de produção de sentidos. 
Os métodos de análise midiática, tais como a análise semiótica e a análise do discurso, comumente aplicados aos estudos sobre a publicidade, a imprensa e a indústria cultural, podem ser especialmente úteis na análise da rotulagem de alimentos, uma vez que dão conta de explicitar a geração de sentidos na emissão das mensagens. Assim, decidiu-se inaugurar a aplicação do método da análise qualitativa do discurso ao estudo de emissão de rótulos de alimentos.

O corpus de análise escolhido é composto de embalagens de produtos da categoria dos "cereais matinais". A partir de visitas a supermercados, lojas de "alimentos naturais", empórios e sacolões da cidade de São Paulo, além de pesquisa na internet, entre outubro de 2012 e julho de 2013, foram identificados mais de 70 produtos e 35 marcas de produtos da categoria dos "cereais matinais", nome atribuído pelo varejo a produtos caraterizados pela composição de cereais integrais e/ou processados e destinados ao consumo com leite, iogurte ou frutas, no desjejum. Pertencem a essa categoria as granolas, os flocos de milho e as misturas adoçadas de farinhas e farelos de cereais.

A coleta de dados se deu a partir de fotografias e anotações feitas nos pontos de venda. O objetivo não era registrar todos os produtos da categoria, mas captar a variedade de conteúdos e linguagens das embalagens. Foram considerados como dados para análise os elementos comunicacionais impressos em toda a superfície externa das embalagens: nome do produto, slogan do produto, imagens e ilustrações, marca, slogan da marca, descrição do produto, selos, informação nutricional, textos de todo tipo, símbolos, cores, números, medidas etc., além de formato e material da embalagem.

A análise de discurso não tem finalidade estatística. O corpus de análise é uma construção do analista e deve ser representativo dos discursos encontrados. Segundo ORLANDI (2012a), a delimitação do corpus deve buscar não a exaustividade horizontal, ou seja, a quantidade de objetos em que o discurso se aplica, mas a exaustividade vertical, em profundidade (p. 62). O objetivo da análise empírica aqui é identificar os discursos presentes em embalagens de "cereais matinais", buscando identificar quais vínculos de sentido são gerados nas dimensões saúde/ nutrição, sustentabilidade e cultura alimentar. 
Assim, a análise empírica procurou: identificar os elementos comunicacionais verbais e não verbais usados para transmitir mensagens que relacionem o consumo do produto a saúde/ nutrição, a sustentabilidade e aos costumes, incluindo palavras, textos, imagens, mascotes, selos, gráficos, números e tabelas; expor os potenciais percursos de leitura e interpretação; explicitar os gêneros e as formações discursivas que esses elementos expressam; caracterizar os sujeitos enunciadores e coenunciadores desses discursos e explicitar como se legitimam como tais; revelar as ideologias e instituições mediadoras dos rituais de consumo explícita ou implicitamente propostos. Procurou-se responder a perguntas tais quais: "Como se constituem os sujeitos?”, “Quais planos de expressão são privilegiados?”, “Quais campos discursivos se formam?", “Quais comportamentos são incentivados?”, “Quais informações e discursos são apagados?”.

A primeira etapa da análise consistiu em caracterizar o ethos da marca na embalagem, ou seja, qual a imagem de si que a marca procura construir a partir do que diz e de como o diz. Nessa mesma etapa, também foi identificado o ethos do interlocutor, ou seja, qual a imagem do consumidor presumida pela marca para estabelecer sua comunicação nos termos escolhidos.

Neste trabalho, a caracterização do ethos destina-se a explicitar a imagem de si que as marcas de "cereais matinais" expressam em relação à alimentação saudável (cuidado com a saúde/ nutrição, responsabilidades socioambientais, cultura alimentar) e à satisfação pessoal do consumidor, dando-se autoridade sobre esses temas e poder para gerar sentidos, influenciar e mediar as práticas de consumo.

O processo de delimitação do corpus de análise neste trabalho demandou tempo e repetidas consultas às bases teóricas e às imagens coletadas. Todas as imagens captadas e todas as anotações registradas foram exaustivamente examinadas com a finalidade de extrair o ethos da marca em cada embalagem. Foram utilizados formulários e tabelas para organizar os dados e facilitar a comparação entre eles. Foram experimentadas comparações entre produtos de uma mesma marca e entre produtos semelhantes de marcas diferentes. Foram considerados a quantidade de texto, o tamanho das ilustrações e imagens, a presença e a ausência de selos, as palavras mais usadas, as frases mais incomuns. 
Foram comparadas as estratégias de comunicação com as características dos produtos. E, uma vez caracterizados os ethe de todas as embalagens, estes foram comparados e checados novamente para a identificação das embalagens mais representativas de cada um deles.

A elaboração de propostas para o fortalecimento do discurso oficial da alimentação saudável nos rótulos, terceiro objetivo específico deste trabalho, foi possível a partir de um cruzamento dos resultados da revisão da literatura e da análise empírica. 


\section{RESULTADOS E DISCUSSÃO}

Devido à extensão das descrições e análises, optou-se por reunir os resultados do estudo e a discussão dos resultados no mesmo capítulo. Primeiro, são apresentados os resultados da revisão bibliográfica específica, seguida de uma discussão sobre os estudos encontrados. Depois, são descritos os resultados da análise empírica das embalagens, discutidos ao longo da descrição e também, de forma mais sintética, ao final. Por fim, os resultados e a discussão dessas duas etapas da análise servem de base para a elaboração de propostas para novos estudos, que corresponde ao terceiro objetivo específico do trabalho.

\subsection{ESTUDOS DE EMISSÃO E RECEPÇÃO}

O resultado da primeira etapa deste estudo consiste numa seleção de artigos sobre a emissão e a recepção de rótulos de alimentos, com atenção a algumas de suas conclusões.

Estudos de emissão, grosso modo, examinam ou reelaboram os critérios usados pelo emissor das mensagens na escolha das informações e da linguagem, as linguagens utilizadas, suas origens e influências e suas potencialidades interpretativas. Os estudos de recepção investigam o efeito das mensagens sobre seu público - se foram interpretadas do modo esperado, se foram compreendidas, como foram aproveitadas - e também os interesses do público pelas mensagens que já estão sendo transmitidas e que ainda não estão. Há também estudos que examinam tanto a emissão quanto a recepção de um mesmo rótulo.

Estudos de recepção e de emissão de rótulos de alimentos não são exclusividade da área de saúde e nutrição. Pesquisadores de áreas como economia, 
psicologia, pedagogia e marketing também têm interesse em entender como se dá a comunicação entre a indústria de alimentos e seu público por meio das embalagens. Esta revisão bibliográfica não faz distinção prévia entre métodos nem áreas de origem desses estudos, pois o objetivo é examinar os tipos de estudos já feitos e extrair deles o que há de relevante. Houve um esforço especial em encontrar estudos sobre ecorrótulos e rotulagem integrada.

A maior parte dos estudos encontrados analisa a recepção da rotulagem nutricional. Vários examinam qual o interesse dos consumidores pela leitura da informação nutricional, buscando identificar quais informações são mais lidas, os motivos da leitura, a frequência de leitura, a qualidade da interpretação das informações e sua relação com conhecimentos em nutrição (MONTEIRO et al, 2005; DRICHOUTIS \& LAZARIDIS, 2005; BORRA, 2006; NØRGAARD \& BRUNSØ et al, 2009; WILLS et al, 2009; FERNANDES et al, 2010; GRUNERT et al, 2010; KEMPEN et al, 2011; IDEC, 2013; PARKS, 2013; SCHROETER \& ANDERS, 2013). Outros buscam explicações para a resistência e as dificuldades dos consumidores no uso dos rótulos (BARONE et al, 1996; ROTHMAN et al, 2006; MARINS et al, 2008; BENDINO et al, 2012) e levantam sugestões dos consumidores para facilitar esse uso (SOUZA et al, 2011).

Há pesquisas como a de CAVADA et al (2012), que procuram identificar quais perfis de público demonstram maior interesse na rotulagem nutricional. Algumas examinam o uso dos rótulos por grupos etários específicos, como jovens adultos (SHARF et al, 2012), estudantes universitários (NURLIYANA et al, 2011), adolescentes (WOJCICKI \& HEYMAN, 2012; SHEKHAR \& RAVEENDRAN, 2013; SAHA et al, 2013), jovens e idosos (MILLER \& CASSADY, 2012).

As relações da leitura dos rótulos com o gênero e as etnias também aparecem na literatura. AHMADI et al (2013) estudaram o nível de conhecimento sobre nutrição e a percepção da rotulagem nutricional de mulheres iranianas. STRAN \& KNOL (2013) observaram que as mulheres verificavam e utilizavam componentes dos rótulos com mais frequência e mais profundamente do que os homens e que indivíduos de origem hispânica consultavam e usavam rótulos com mais frequência que homens brancos não hispânicos. 
$\mathrm{O}$ uso da rotulagem nutricional por grupos com doenças ou necessidades nutricionais específicas são o foco de estudos como os de LWIN et al (2013) e PETERSEN et al (2013). Também foi investigada a atenção à informação sobre nutrientes específicos nos rótulos, como gorduras totais, gordura saturada, colesterol (KIM et al, 2000; LIN et al, 2004), gordura trans (JASTI \& KOVACS, 2010; ELLIS \& GLANVILLE, 2010) e categorias do tipo nutrientes "qualificantes" e "desqualificantes" (HOEFKENS et al, 2011).

Diversos estudos se debruçaram sobre os efeitos das alegações nutricionais e de saúde sobre os consumidores a fim principalmente de verificar se tais alegações eram bem aceitas, interpretadas corretamente e se contribuíam para a compra de alimentos mais saudáveis (MAZIS \& RAYMOND, 1997; NAYGA JR., 2000; SANCHEZ \& CASILLI, 2008; WILLS et al, 2009; HARRIS et al, 2011; GRUNERT et al, 2011; SVEDERBERG \& WENDIN, 2011; LWIN et al, 2013; WEZEMAEL et al, 2014). BONANNI et al (2013) investigaram o potencial da rotulagem de alimentos em promover a dieta mediterrânea na Itália.

Há ainda estudos recentes com consumidores dos Estados Unidos e Europa investigando os efeitos dos modelos de rotulagem nutricional frontal, tais como o semáforo nutricional, o NuVal e o Guiding Stars (WILLS et al, 2009; BALCOMBE et al, 2010; HAWLEY, 2012; ROBERTO et al, 2012; ANTÚNEZ et al, 2013; EMRICH et al, 2013; ASCHEMANN-WITZEL et al, 2013; BUI et al, 2013; KOENIGSTORFER et al, 2013; RAHKOVSKY et al, 2013; SAVOIE et al, 2013; BIALKOVA et al, 2014; KEES et al, 2014).

Não se pretendeu fazer uma revisão sistemática desses estudos a fim de tecer conclusões definitivas sobre a eficácia da rotulagem nutricional, mas a leitura dos artigos citados permitiu notar que no mundo todo o interesse do consumidor pela informação nutricional nas embalagens, sua capacidade de compreensão dessa informação e o uso que ele faz dela constituem uma problemática relevante para a saúde pública. Diversos estudos revelam resultados pouco animadores, sugerindo que a informação nutricional tal qual as legislações a preveem não é suficiente para orientar a escolha de alimentos mais saudáveis. Alguns autores 
concluem que a solução está em educar os consumidores. Outros acreditam que é preciso modificar a rotulagem.

HIEKE \& TAYLOR (2012) fizeram uma revisão sistemática de artigos sobre rotulagem nutricional publicados ao longo de 30 anos e constataram que ainda pairam muitas dúvidas acerca do que é adequado informar ao consumidor Por exemplo, enquanto alguns estudos sugerem que muita informação no rótulo atrapalha, outros dizem que afirmações extremamente sucintas podem levar a engano. Em relação ao formato, a revisão mostra que, segundo a maioria dos estudos, a informação sobre impactos nutricionais negativos do consumo do produto no rótulo é mais efetiva, crível e compreensível para o consumidor do que a informação sobre impactos positivos. Isso não significa, no entanto, que a informação negativa influencie mais o comportamento do consumidor, pois este dependeria do envolvimento da pessoa com o tema abordado.

$\mathrm{Na}$ revisão sistemática de HERSEY et al (2013), 38 estudos de recepção empíricos sobre a rotulagem nutricional frontal foram examinados. Eles concluem que os consumidores têm mais facilidade para interpretar rótulos da categoria nutrientes específicos que incorporem texto e uma simbologia de cores do que modelos numéricos, tais como o VDR. E sugerem que mais pesquisas são necessárias para conhecer o comportamento do consumidor diante da rotulagem em situações reais de compra.

TEMPLE \& FRASER (2014) fizeram uma revisão para determinar o papel da rotulagem (frontal inclusive) na informação dos consumidores dos Estados Unidos e Canadá sobre a composição dos alimentos. Os resultados mostraram que os consumidores têm dificuldade em entender a informação apresentada tanto na frente quanto no verso das embalagens. Os pesquisadores sugerem que, para a rotulagem frontal que usa código e cores, uma quarta cor seja adicionada ao semáforo para indicar de modo global quão saudável é o produto. Também recomendam que o verso da embalagem traga uma rotulagem mais clara. Eles concluem que os rótulos nos Estados Unidos e Canadá precisam ser reformulados. Os autores preveem que a implementação de um novo sistema de rotulagem será 
combatido pela indústria de alimentos e recomendam a realização de novos estudos sobre a efetividade dos designs de rótulos.

Diante das dificuldades de leitura da rotulagem nutricional mostrada por tantos estudos, alguns autores procuraram estabelecer uma relação entre o nível de capacidade de fazer escolhas alimentares saudáveis e a habilidade em interpretar as informações nos rótulos. CHA et al (2014) examinaram as relações entre a literacia para saúde (health literacy), a autoeficácia, o uso dos rótulos e a qualidade da alimentação em adultos. O grupo com baixa literacia em saúde apresentou uso da rotulagem significativamente menor que o grupo de alta literacia. Os autores concluem que estratégias para aumentar a literacia para saúde, a autoeficácia e o uso dos rótulos deveriam ser desenvolvidas.

Mas "literacia para comer" seria um conceito em construção. VIDGEN \& GALLEGOS (2014) tentaram estabelecer uma definição para o termo "food literacy". Suspeitando que a visão dos profissionais sobre fatores protetores da alimentação seria diferente da visão das pessoas comuns, os autores consideraram duas perspectivas: a dos profissionais especialistas representantes de alguma política existente e a dos indivíduos, que podem ser vistos como especialistas em "se virar" para comer todos os dias. Os pesquisadores esperavam identificar um conjunto quantificável de competências de literacia para comer que pudessem ser medidos em indivíduos e populações. No entanto, os resultados destacaram a importância do contexto, o que dificulta o desenvolvimento de uma medida. O conceito a que os pesquisadores chegaram tem a ver com resiliência. Eles discutem que pesquisas anteriores podem ter simplificado demais os componentes da literacia para comer ao focar somente em alguns elementos, tais como cozinhar, preparar refeições ou conhecimento sobre nutrição, e por isso falharam em capturar a totalidade da questão. Ao fazê-lo, as pesquisas anteriores teriam potencialmente subestimado a importância dessa totalidade nas influências sobre o consumo de alimentos.

A definição de food literacy a que eles chegaram é a seguinte: o arcabouço que empodera os indivíduos, famílias, comunidades ou nações para proteger a qualidade da sua alimentação por meio da mudança e fortalece a resiliência alimentar ao longo do tempo. É composta de um conjunto de conhecimentos inter- 
relacionados, habilidades e comportamentos necessários para planejar, gerenciar, selecionar, preparar e comer alimentos que atendam às necessidades. Ou, dito de outro modo, são as ferramentas necessárias para se relacionar de modo saudável com a comida ao longo da vida.

Vários dos estudos citados até aqui investigaram a relação dos consumidores com a informação nutricional nos rótulos de forma direcionada e isolada, sem considerar a relação que os consumidores têm com outros elementos comunicacionais das embalagens. Um estudo que foge a esse padrão é o de LAPIERRE et al (2011), que investigou se a presença de mascotes nas embalagens de produtos alimentícios voltados ao público infantil influenciava a avaliação do sabor dos produtos pelas crianças. Os participantes tinham de avaliar o sabor dos produtos usando uma escala de cinco pontos representada por emoticons (1- não gosto nem um pouco; 5- gosto muito). As crianças apresentadas à embalagem com mascote disseram gostar do produto mais que aquelas que viram a embalagem sem mascote. Aquelas a quem o produto foi apresentado pelo nome "Healthy Bits" gostaram mais do cereal do que aquelas para quem o produto se chamava "Sugar Bits”. A presença da mascote foi particularmente influente na avaliação do sabor do produto quando seu nome era Sugar Bits.

Dentre os estudos de recepção com adultos que buscam observar outros aspectos da leitura dos rótulos estão aqueles que usam a técnica do rastreamento do olhar a fim de identificar o nível de atenção espontânea dos consumidores à informação nutricional e outros elementos da embalagem (BONSMANN et al, 2010; MILLER \& CASSADY, 2012; ANTÚNEZ et al, 2013; ARES et al, 2013; KOENIGSTORFER et al, 2013; TURNER et al, 2014; BIALKOVA et al, 2014). GASCHLER et al (2010) mediram o tempo detecção de diferenças entre embalagens quase idênticas por consumidores de diferentes idades.

Também merecem ser citados artigos que examinam as preferências dos consumidores por informações e formas de apresentação das informações (BANTERLE et al, 2012; LOWE et al, 2013; WEZEMAEL et al, 2014). LOWE et al (2013) examinaram as preferências dos consumidores por aparatos tecnológicos alternativos que pudessem auxiliar no processamento da informação nutricional dos rótulos. Após a análise, dividiram os consumidores em três segmentos: inovadores 
famintos por informação; leitores ativos de rótulos; e espectadores. Os autores acreditam que é preciso desenvolver soluções customizadas para a comunicação da informação nutricional, questão com a qual a tecnologia poderia contribuir.

Outro trabalho que merece atenção é o de FORWOOD et al (2013), que testaram o efeito de combinações de mensagens referentes ao sabor e à saúde sobre o interesse de consumidores pelo consumo de frutas, numa combinação de estudo de emissão com recepção. Partindo da constatação de que as pessoas tendem a dar mais valor ao sabor do que à saúde na escolha de alimentos, os pesquisadores decidiram medir o impacto de uma rotulagem que ressaltasse o sabor das frutas. Cinco rótulos foram aplicados a maçãs: 1) maçã; 2) maçã saudável; 3) maçã suculenta; 4) maçã saudável e suculenta; 5) maçã suculenta e saudável. A tarefa dos 439 participantes era escolher entre uma maçã e uma barra de chocolate como sobremesa.

Foram registradas as qualidades percebidas na maçã (sabor, saúde, valor, qualidade, saciedade) e as características dos participantes (constrangimento, crença em que alimentos saborosos não são saudáveis, IMC). Na comparação com as maçãs sem descritores, os rótulos que combinavam descritores de sabor e de saúde aumentaram significativamente a escolha de maçãs. $O$ uso de um descritor único não impactou a escolha da fruta. $\mathrm{O}$ preditor mais forte da escolha da fruta foi a avaliação do sabor e a ausência de crença em que alimentos saborosos não são saudáveis. Os pesquisadores concluem que intervenções que enfatizem os atributos de sabor de alimentos saudáveis terão mais chance de funcionar na promoção da alimentação saudável do que aquelas focadas apenas na saúde.

Há ainda a pesquisa de GRABENHORST et al (2013), que usaram o método da ressonância magnética funcional para investigar os efeitos de uma rotulagem simples e intuitiva. A hipótese dos pesquisadores era que rótulos simples e intuitivos engajariam sistemas cerebrais ligados às emoções da mesma forma que estratégias de comunicação de marketing bem sucedidas e seriam mais efetivos na promoção da alimentação saudável que a mera apresentação de informação nutricional. Para testar essa hipótese, eles recrutaram pessoas saudáveis para realizar tarefas de avaliação e escolha de alimentos quando estavam com uma leve fome. A principal manipulação do experimento foi apresentar pares de fotos de 
alimentos idênticos com rótulos simples que enfatizavam dois atributos diferentes: benefício de sabor (numa linguagem comumente usada na comunicação de marketing, do tipo "suculento e doce") e propriedades relacionadas à saúde (com alegações do tipo "baixo conteúdo de gorduras").

Os resultados mostram que esses rótulos influenciaram a avaliação dos alimentos na amídala, um sistema emocional chave no cérebro. Quando o rótulo influenciava a avaliação da propriedade relacionada à saúde, a força desse viés era preditora de mudanças comportamentais em direção a escolhas mais saudáveis. No momento da decisão, a atividade da amídala codificava variáveis-chave de decisão, potencialmente refletindo uma participação ativa da amídala na escolha do alimento. Os pesquisadores acreditam que tal descoberta reforça o potencial de utilidade da rotulagem na política pública e indica o papel crucial dos sistemas emocionais do cérebro quando a rotulagem guia as escolhas alimentares.

Esta revisão trouxe alguns estudos sobre rotulagem de alimentos orgânicos, transgênicos, alimentos produzidos localmente, com declaração de origem, pescados sustentáveis e outras informações de interesse para públicos "verdes", principalmente oriundos da área econômica, com o objetivo de favorecer campanhas de marketing de empresas interessadas em ampliar o mercado desses perfis de produtos. Infelizmente, não foram encontrados estudos brasileiros com essa abordagem, a não ser sobre a rotulagem de transgênicos, como o de FURNIVAL \& PINHEIRO (2009), que pesquisaram a compreensão da rotulagem de transgênicos entre adultos no interior do estado de São Paulo. E há estudos estrangeiros que investigam realidades ainda tão distantes da nossa em matéria de ecorrotulagem, que foi decidido deixá-los de fora.

Alguns estudos procuram identificar a disposição dos consumidores em comprar (SANGKUMCHALIANGA \& HUANG, 2012; ZEPEDA et al, 2013; DAUGBJERG et al, 2014) ou pagar mais por produtos com alegações "verdes" (CHOLETTE et al, 2013; ROUSSEAU \& VRANKEN, 2013; GARCIA et al, 2014). Outros procuram identificar com quais atributos de sustentabilidade os consumidores mais se importam (HOWARD \& ALLEN, 2006; SPANIOLO \& HOWARD, 2011), ou ainda o entendimento que têm de alegações referentes a questões éticas (HOEK et al, 2012). 
No estudo de ROUSSEAU \& VRANKEN (2013), inicialmente os consumidores estavam dispostos a pagar 33 centavos de euro por quilo de maçã orgânica. Depois de receberem informação sobre os reais impactos da produção orgânica, o limite aceitável subiu para 57 centavos de euro. Os pesquisadores concluem que é preciso fornecer informação mais precisa e confiável sobre processos produtivos socialmente responsáveis e considerar a heterogeneidade das preferências para moldar as políticas conforme grupos específicos.

Na pesquisa de HEMMERLING et al (2013), consumidores de vários países avaliaram o mesmo produto como ligeiramente mais saboroso quando ele estava rotulado como orgânico. Os pesquisadores concluem que a imagem sensorial positiva da categoria de alimentos orgânicos como um todo se transfere para produtos particulares, resultando numa avaliação melhor do sabor. Mas ponderam que esse efeito é relativamente fraco e recomendam um trabalho de melhoria da imagem dos orgânicos como mais saborosos.

HAASA et al (2013) usaram associação de palavras para captar as imagens que os consumidores associam a alimentos orgânicos e produzidos localmente. Os alimentos locais foram associados a imagens de fazenda, fazendeiros, animais felizes, paisagens bonitas, frescor e flores. Os orgânicos foram associados a alimentação saudável, melhores métodos de produção, saúde pessoal, saúde da família, valor nutricional, natural, melhor alimentação animal e não uso de transgênicos. Estudos desse tipo podem ajudar a entender como os consumidores potencialmente podem interpretar informações nos rótulos.

Em lugares onde ecorrótulos ainda não existem, há pesquisas testando a viabilidade de adotá-los (RECZKOVA et al, 2013). BANTERLE et al (2012) organizaram grupos focais e uma pesquisa com 240 pessoas para analisar o interesse dos consumidores de Milão, na Itália, por elementos da rotulagem e procuraram determinar quais tipos adicionais de rotulagem poderiam melhorar suas escolhas. Eles testaram inclusive alternativas de rotulagem digital via smart phone. Os consumidores quiseram saber a origem dos produtos e se eram transgênicos. Das informações que não estavam presentes, foram mencionados o impacto ambiental, o bem-estar animal e o modelo de criação. 
Poucos são os estudos encontrados que investigam simultaneamente o interesse dos consumidores por informações nutricionais e "verdes" em rótulos de alimentos. Em geral, os dois tipos de rotulagem são estudados separadamente.

Podemos observar que muitos dos estudos de recepção de rótulos de alimentos citados, especialmente aqueles focados na rotulagem nutricional, investigam os efeitos de um modelo de comunicação baseado no mecanismo da transmissão de informação de um emissor (o fabricante) a um receptor (o consumidor). Segundo essa concepção informacional da comunicação, bastaria apresentar uma informação no rótulo a um consumidor suficientemente educado para ler e interpretar essa informação (o receptor ideal) para que este quase que automaticamente aproveitasse essa informação em suas decisões. Qualquer problema na utilização da informação seria explicado, portanto, por um defeito no receptor da mensagem, ou seja, na falta de educação, na baixa literacia, na falta de atenção. Os estudos que enxergam o processo comunicacional dessa forma tendem a apontar soluções educativas para a baixa eficácia da rotulagem. Acredita-se que é preciso modificar o receptor, não a mensagem.

Um paradigma diferente aparece em estudos sobre a rotulagem frontal, que já demonstram a percepção de que a rotulagem nutricional padrão não funciona e que se faz necessário repensá-la. Estudos como os de ARES et al (2011), LAPIERRE et al (2011), FORWOOD et al (2013), GRABENHORST et al (2013), LOWE et al (2013) e VIDGEN \& GALLEGOS (2014), entre outros, sugerem que não é apenas a informação em si que importa, mas todo o contexto em que ela é apresentada, além do perfil do público a quem ela se apresenta.

Segundo DOWNS et al (2009), há pouca evidência de que a informação por si dê conta de melhorar a dieta. HORNICK et al (2013) questionam se o acesso fácil à informação nos dias atuais ajudou ou atrapalhou os consumidores na tentativa de se alimentar de forma mais saudável e chegam a levantar a hipótese de a comunicação tradicional sobre nutrição ter contribuído para confundir e desmotivar os americanos. COLBY et al (2010) analisam a distribuição da frequência do marketing nutricional nas embalagens e concluem que o uso de alegações nutricionais pode não estar ajudando os consumidores a escolher alimentos com menos gordura saturada, sódio ou açúcar. 
TARABELLA \& VOINEA (2013) fizeram uma revisão da literatura sobre modelos de rotulagem nutricional frontal a fim de estabelecer critérios para a criação de um modelo mais adequado. Além dos bastante explorados semáforo nutricional e VDR, a revisão incluiu também o Healthy Eating System (HES), da Austrália, que ressalta o conteúdo de nutrientes e a presença de ingredientes integrais e avisa se o produto deve ser consumido sempre, ocasionalmente ou raramente. As autoras concluem que uma rotulagem frontal ótima: não deve exigir do consumidor conhecimento avançado em nutrição nem grande esforço de interpretação das informações; o design deve chamar a atenção do público, ser compreensível e útil; deve ser adaptado às políticas e recomendações alimentares oficiais; deve guiar os consumidores na adequada inclusão do produto em sua dieta; e deve ser obrigatória.

O estudo de ENGELS et al (2010) envolveu entrevistas com especialistas e também com consumidores para levantar quais informações deveriam constar nos rótulos dos alimentos. Os autores concluíram que um rótulo de escopo abrangente, que incorporasse ao mesmo tempo valores ecológicos, econômicos, sociais, de conveniência, sabor, qualidade e saúde, poderia influenciar padrões de consumo consideravelmente e facilitar comparações entre produtos.

Segundo os pesquisadores, o rótulo ideal resumiria toda essa informação incluindo as já fornecidas e as que faltam - de forma simples, a partir de uma pontuação geral de sustentabilidade para cada produto, sinalizada com as cores do semáforo, com base em uma metodologia - que deveria ser única e universal - de avaliação modular de sustentabilidade. Dessa forma, evitar-se-ia o "green washing" pelos fabricantes e a profusão de mensagens conflitantes que confundem o consumidor.

O modelo proposto por ENGELS et al (2010) seria usado em todos os produtos alimentícios conforme classificações aplicáveis a todas as categorias de produtos. Em vez de apenas os alimentos orgânicos levarem um selo, todos os alimentos seriam identificados como, por exemplo, produtos da agricultura 1) orgânica, 2) integrada ou 3) convencional. Todos seriam identificados também pelo impacto da origem, calculado de acordo com as distâncias percorridas para levar o alimento do campo ao prato. Também seria apresentado o impacto da embalagem, 
com base nos materiais usados. O mesmo seria feito para os modos de estocagem e consumo.

Medir o impacto ambiental global dos alimentos seria o primeiro passo para definir quais informações referentes à sustentabilidade deveriam ser apresentadas nos rótulos. Por esse tipo de medição, a carne e alimentos frescos transportados por avião foram classificados como alimentos altamente poluentes (ENGELS et al, 2010).

Outros aspectos importantes para a análise da sustentabilidade dos alimentos proposta pelos autores são: o sabor, a conveniência, a qualidade e a saúde (estudos citados no artigo mostram que os consumidores associam o sabor à qualidade e que a conveniência é altamente valorizada, especialmente entre os jovens solteiros); a contribuição para a riqueza da nação (produtores locais e regionais seriam beneficiados se seus produtos levassem maior pontuação); e a relação do produto com a cultura e a identidade nacionais (nesse aspectos os produtos locais, regionais e nacionais também levariam vantagem) (ENGELS et al, 2010).

Para a classificação dos produtos em todos os quesitos, os autores estabeleceram uma escala de pontos variando de -50 a +50 , com impactos indesejados situados de -50 a -11 (cor vermelha), efeito neutro de -10 a +10 (cor amarela) e impactos desejados de +11 a +50 (cor verde). A partir daí, três modelos de avaliação foram experimentados.

O primeiro modelo baseou-se em cinco critérios: 1) contribuição para a saúde; 2) qualidade e sabor; 3) conveniência; 4) impactos ambientais; e 5) contribuição para a riqueza nacional. As pontuações por critério foram representadas por setas de diferentes comprimentos posicionadas sobre uma escala com as cores do semáforo e os quesitos avaliados, e a pontuação geral foi apresentada acima da escala. Texto e setas predominaram.

O segundo modelo teve critérios um pouco diferentes: 1) produção; 2) origem e meio de transporte; 3) embalagem; 4) estocagem; 5) consumo. Desta vez, as pontuações numéricas foram associadas às cores do semáforo e a ícones que visaram a facilitar o reconhecimento do impacto analisado. Foram usados texto, ícones e números. O terceiro modelo combinou os dois anteriores (Figura 12). De 
acordo com as entrevistas realizadas com especialistas e consumidores, o segundo modelo (parte inferior do quadro na Figura 12) seria o mais bem aceito.

Figura 12. Modelo de rotulagem de alimentos com representação dos impactos sociais, ambientais, econômicos e culturais do produto.

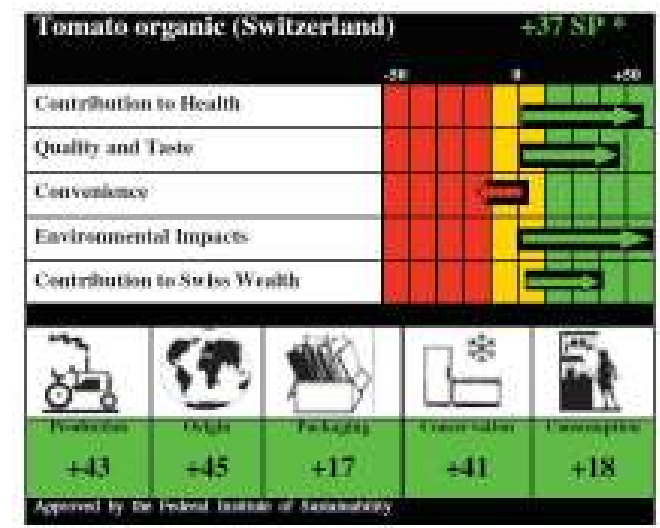

Extraído de: ENGELS et al (2010).

TZILIVAKIS et al (2012) jugam que ainda é cedo para criar um modelo de rótulo que se pretenda completo, por considerarem que a ciência nessa área ainda não é suficientemente robusta ("a ciência e a prática do uso dos rótulos para promover mudanças no consumo e nas atividades da indústria são complexas"), mas propõem uma série de recomendações para o desenvolvimento futuro de um modelo de rotulagem com potencial para modificar tanto o comportamento do consumidor quanto o da indústria. As recomendações visam principalmente à clareza e à transparência quanto aos critérios de avaliação do produto e seus processos usados na rotulagem.

Segundo os autores, os objetivos do(s) esquema(s) usado(s) na rotulagem devem ser claros e transparentes (porque o que funciona para estimular a reformulação de produtos nem sempre funciona para modificar os hábitos das pessoas); as categorias de impacto cobertas devem ser claramente declaradas; os métodos de aferição devem ser claramente identificados; os vetores e mecanismos que permitirão alcançar os objetivos devem ser claramente identificados e entendidos; o esquema usado deve complementar outras iniciativas que enfrentem os mesmos problemas e identificar claramente quaisquer benefícios adicionais 
apresentados por ele; o papel dos vetores e das metas baseadas em prática e em resultados, bem como a relação entre eles e o alcance dos objetivos do esquema, devem ser claramente entendidos; as melhores técnicas disponíveis devem ser usadas para medir e avaliar impactos robustos e críveis; a inclusão de dados sobre impactos deve respeitar os limites das técnicas estabelecidas (de modo que façam sentido); o custo de adotar o esquema deve ser equitativo e proporcional aos seus potenciais benefícios; abordagens comunicacionais devem variar conforme o público-alvo; a comunicação dos impactos deve se basear em dados agregados de forma transparente e confiável; os métodos de comunicação de impactos no rótulo devem ser o mais simples possível; os limites do que o rótulo abarca devem ser claramente comunicados (TZILIAVAKIS et al, 2012).

Em tese, continuam os autores, "qualquer rótulo ambiental deveria se basear nos impactos ambientais mais significativos associados ao ciclo de vida do produto ou ao seu sistema de produção". No entanto, a escolha dos impactos a serem declarados geralmente obedece ao que pode ser medido e avaliado dentro dos custos que podem ser assumidos e à busca de equilíbrio entre os pontos de vista envolvidos. "Omnirrótulos" (esquemas que indicam uma multiplicidade de impactos, de ambientais a sociais e culturais) são, em tese, melhores que esquemas que apontam apenas um tipo de impacto, mas os custos de incluir determinados impactos no rótulo podem terminar inviabilizando a inclusão de outros (TZILIAVAKIS et al, 2012).

Além disso, vale enfatizar que um rótulo será sempre uma forma simplificada de comunicar algo complexo. Dito isso, é possível afirmar que, ao menos por enquanto, dificilmente um rótulo irá apresentar todos os impactos da produção, distribuição, consumo e descarte do produto. Essa seleção de impactos, métodos e informações a serem abertas envolve, portanto, exclusões e perdas que, segundo TZILIVAKIS et al (2012), também devem ser claramente expostas ao mercado.

Motivado por preocupações quanto à confusão potencialmente causada pela miríade de ecorrótulos usados no mundo, DENDLER (2013) examinou a possibilidade de se criar uma rotulagem única, integrativa, para informar impactos ambientais e de sustentabilidade, que ele chamou de Metamodelo de Rotulagem de Sustentabilidade. O autor sustenta sua análise num quadro teórico integrativo que 
combina argumentos teóricos do institucionalismo construtivista, do empreendedorismo institucional e o conceito de legitimidade para explorar as lacunas na discussão conduzida até então sobre a metarrotulagem e investigar as perspectivas dali para frente. $\mathrm{O}$ estudo consiste numa análise documental e em entrevistas focadas em estudos de caso de quatro modelos de rotulagem (EU ecolabel, EU energy label, Marine Stewardship Council and Fairtrade label).

A pesquisa mostrou que, mais do que comunicar numa linguagem adequada, um metarrótulo deveria conseguir justificar sua superioridade sobre os ecorrótulos já existentes e abranger a heterogeneidade das questões da sustentabilidade nos diversos países em que fosse adotado. A legitimidade do emissor desse metarrótulo seria um dos quesitos mais importantes a garantir, uma vez que todos os emissores de ecorrótulos já existentes enfrentaram questionamentos sobre sua legitimidade. Há ainda o custo: os métodos de aferição necessários para tal objetivo podem sair caros demais.

Se o propósito de um metarrótulo é agregar informações numa comunicação única, há estudos que concluem que, quanto mais ampla a agregação, mais compreensível a informação será para os consumidores. Outros pesquisadores colocam, porém, que o grau adequado de agregação da informação dependerá do contexto dessa comunicação. Uma alternativa já sugerida é adotar não uma única medida, mas subcategorias, mais ou menos como faz o GoodGuide (DENDLER (2013). O autor conclui que, diante dos desafios para a adoção de uma rotulagem única, os emissores de ecorrótulos já existentes deveriam buscar meios de gerenciar sua legitimidade como caminho para a institucionalização dessa rotulagem.

Segundo BREMMERS (2012), o campo da informação sobre alimentos é complexo, já que inclui aspectos legais, sociopsicológicos e econômicos. A resposta sobre qual informação deve ser oferecida aos consumidores dependeria então de pesquisas independentes sobre todos esses aspectos. Assumindo que o quadro regulatório atual na Europa tem falhas que atrapalham a inovação, o autor defende uma abordagem integrada para aprimorar o entendimento dos múltiplos efeitos da informação sobre alimentos e facilitar a provisão de políticas efetivas. A abordagem que ele sugere retira do consumidor a centralidade das preocupações e tenta dar mais voz à iniciativa privada. Em vez de levar em conta apenas o medo do 
consumidor diante de novidades tecnológicas, como a nanotecnologia e os transgênicos, ele diz que a informação deveria ser baseada em evidências e respeitar os direitos dos demais stakeholders, entre os quais as empresas de alimentos.

Uma coisa é o propósito de informar e a expectativa de influenciar decisões por meio da informação. Outra coisa é o uso dessa informação pelo público. A fim de checar qual o grau de correspondência entre os sentidos pretendidos pelos emissores das mensagens nos rótulos e os sentidos captados pelos consumidores, ARES et al (2011) utilizaram análise semiótica e associação de palavras. O objetivo era verificar se os consumidores percebiam os rótulos da mesma forma que os analistas semióticos previam, considerando diferenças culturais entre dois países.

Primeiro, os pesquisadores fizeram um levantamento dos modelos de rótulos existentes em embalagens de iogurte "natural". Depois, especialistas em semiótica analisaram os elementos comunicacionais não verbais desses rótulos, tais como imagens, estrutura visual (posição relativa dos elementos), tipografia e suas combinações. Marca, preço, composição e informação nutricional não foram considerados. A partir da análise semiótica, as mensagens principais presentes nas embalagens foram resumidas e usadas em outra etapa do estudo, com consumidores.

$\mathrm{Na}$ segunda etapa, consumidores da Espanha e do Uruguai responderam questionários online baseados na associação de palavras, método de pesquisa qualitativa usado na psicologia e na sociologia. O objetivo era verificar quais palavras, descrições, associações, pensamentos e sentimentos eram espontaneamente gerados na mente dos consumidores diante dos rótulos e se tais sentidos gerados correspondiam aos esperados.

Para os autores, a análise semiótica de embalagens e rótulos de alimentos pode ajudar a entender e interpretar as associações e expectativas dos consumidores em relação aos produtos e assim direcionar a criação de embalagens que despertem reações específicas no público. A decisão de comparar as reações de consumidores de dois países se deveu à noção de que esse tipo de resposta é influenciado pela bagagem cultural e experiências anteriores, o seja, o contexto da recepção. 
Os pesquisadores afirmam que quatro aspectos de um rótulo geraram associações e expectativas nos consumidores: ilustrações (incluindo o fundo e a textura), a estrutura visual, as cores e a tipografia. Citando K. Spang ["Vender con figuras”. In S. Robles \& M. V. Romero (Eds.), Publicidad y lengua española (pp. 40-53). Sevilla: Comunicación Social Ediciones y publicaciones], os autores lembram que as decisões de compra tendem a se basear mais em aspectos emocionais do que em considerações racionais e argumentam que o significado simbólico das imagens exerce um papel determinante nas associações geradas no consumidor na leitura de um rótulo.

Segundo M. Acaso (El lenguaje visual. Barcelona: Paidós Ibérica, 2009), citado por ARES et al (2011), a estrutura visual de um rótulo é influenciada pela cultura. Nas culturas ocidentais, a leitura é feita da esquerda para a direita, o que sugere que os elementos principais do rótulo serão posicionados no meio ou no lado direito da superfície da embalagem.

Os resultados do teste de associação de palavras em ARES et al (2011) mostraram que algumas das mensagens pretendidas foram devidamente recebidas, e outras não. Os autores consideram que a abordagem multidisciplinar desse estudo foi altamente bem sucedida e sugerem que mais pesquisas sejam feitas com rótulos de alimentos no campo da semiótica e da percepção, focadas em expectativas sensoriais e hedônicas e nas emoções geradas nos consumidores. Os autores também julgam relevante estudar como a interação dos rótulos com o material e o formato das embalagens geram reações nos consumidores.

A grande contribuição do trabalho de ARES et al (2011) é a combinação de um estudo de emissão com um estudo de recepção, lançando mão de um método de análise rotineiramente aplicado à publicidade para investigar os sentidos gerados pelos rótulos em sua integralidade. Esse tipo de estudo pode nos ajudar a rever com mais cuidado a totalidade das mensagens que estão sendo captadas pelos consumidores via rotulagem, para muito além das informações técnicas apresentadas.

Os estudos de emissão de rótulos de alimentos são bem menos frequentes que os de recepção, o que sinaliza ao mesmo tempo uma lacuna na literatura e uma janela de oportunidades. Há, portanto, espaço para novos estudos sobre a emissão, 
que deem conta de examinar os conteúdos, as linguagens e os sentidos gerados na comunicação com os consumidores, a fim de buscar formas de melhorar a qualidade dessa comunicação. 


\subsection{ANÁLISE EMPÍRICA}

As embalagens selecionadas para a análise empírica neste trabalho pertencem à categoria que o varejo identifica como sendo a dos "cereais matinais". As aspas se justificam neste texto pelo fato de tal designação ser historicamente construída e não refletir uma identidade universal, inquestionável ou mesmo brasileira desse tipo de produto.

Nos supermercados visitados, pacotes de flocos de milho, produtos processados feitos de farinhas com açúcar e misturas de grãos integrais com frutas secas costumam estar posicionados num mesmo corredor ou prateleira, sinalizados com uma placa de identificação da categoria. Há estabelecimentos em que os produtos orgânicos e/ou dietéticos da categoria se situam numa seção à parte. Em alguns sacolões e lojas de produtos naturais, parece haver uma seleção mais criteriosa desses produtos, uma vez que itens mais processados e açucarados estão ausentes.

A forma como o estabelecimento apresenta os produtos dessa categoria ao consumidor funciona como um primeiro guia de leitura e interpretação, portanto gera sentidos. A placa de sinalização do setor dentro da loja classifica esses produtos como destinados ao consumo matinal. O posicionamento de produtos de diferentes graus de processamento lado a lado sugere que são semelhantes e comparáveis segundo os mesmos critérios. A localização dos produtos nas prateleiras, com marcas mais populares dispostas à altura dos olhos dos adultos e marcas menos conhecidas distribuídas pelas prateleiras mais baixas, concretiza uma hierarquia de origem econômica que direciona a atenção do consumidor ao que deve ser percebido antes.

O formato, o material e o desenho gráfico das embalagens contribuem para essa diferenciação. Caixas de papelão iguais posicionadas de pé na prateleira, lado a lado, funcionam como um cartaz de promoção das marcas, ao passo que sacos plásticos deitados só serão vistos por inteiro se o consumidor os puxar com a mão. 
No caso das caixas, o tamanho, a quantidade de caixas na prateleira, as cores, as imagens na face frontal e a popularidade da marca também têm o potencial para direcionar o olhar dos consumidores que passam na frente da prateleira, numa disputa por sua preferência.

Os consumidores que passam na frente da prateleira, por sua vez, percebem os produtos expostos com um olhar que é mediado por sua cultura, seu conhecimento, seus hábitos, sua condição socioeconômica, seus desejos, interesses e aspirações, além do conjunto da estratégia de marketing dos produtos e marcas, que passa pela transmissão de mensagens por meio de outras mídias, em outros momentos. Para entender a comunicação que acontece entre as embalagens e os consumidores, é preciso buscar entender quais desses fatores os produtos à venda procuram satisfazer, ou fazem parecer que satisfazem.

Conhecido o contexto de leitura dos rótulos, é necessário analisar suas mensagens, no conteúdo e na forma.

Parte das informações contidas num rótulo é obrigatória, imposta pela legislação do setor e regulada por órgãos governamentais como forma de proteção e garantia dos direitos do consumidor. Como dito anteriormente, a Anvisa obriga que os rótulos de alimentos embalados informem a lista de ingredientes e a composição nutricional dos produtos, bem como dados do fabricante, importador e distribuidor (ANVISA, 2002, 2003). O Ministério da Agricultura e Abastecimento e o Ministério do Desenvolvimento Agrário, por sua vez, padronizam a rotulagem de produtos de origem animal (BRASIL, 2003; MAPA, 2005), frutas e derivados (AGÊNCIA BRASIL, 2004), orgânicos (MAPA, s.d.), produtos da agricultura familiar (MDA, 2012, s.d.) e transgênicos (BRASIL, 2005; MJ, 2003). Outra parte das informações é permitida pela legislação e incluída ou não a critério da marca, como alegações de propriedades nutricionais funcionais (ANVISA, 1999).

As informações obrigatórias estão presentes nas embalagens à revelia dos objetivos da comunicação de marketing das marcas. Já as informações facultativas fazem parte da estratégia de comunicação de marketing das marcas. O restante do conteúdo dos rótulos de alimentos são nomes, slogans, imagens, figuras, selos e demais formatos de mensagens de uso livre, especialmente criados e/ou escolhidos pelas marcas com finalidades mercadológicas, com a permissão dos órgãos de 
controle. Logo, num mesmo rótulo podem estar presentes: as mensagens e linguagens impostas por diferentes órgãos de controle desde a data de publicação da legislação vigente; selos emitidos por entidades certificadoras; e mensagens publicitárias verbais e não verbais criadas pelo departamento de marketing do fabricante para o lançamento do produto.

A análise buscou entender quais os efeitos de sentido potencialmente gerados na emissão simultânea dessas mensagens numa mesma embalagem, a fim de inferir como um conjunto heterogêneo de consumidores pode potencialmente interpretálas e utilizá-las em suas práticas de consumo alimentar. A partir dos dados coletados foi possível caracterizar quatro diferentes ethe que se manifestavam nas embalagens quase sempre de forma incompleta. Ou seja, a postura assumida pelas marcas em relação à satisfação pessoal do público nem sempre correspondeu ao que foi dito sobre sustentabilidade ou saúde, resultando em embalagens com discursos heterogêneos. Além disso, uma mesma marca-mãe podia variar sua forma de comunicação de um produto para o outro, recombinando discursos para direcionar suas mensagens aos diferentes públicos-alvo.

Também foram encontrados rótulos de comunicação muito sutil, que verbalizam pouco mais que o obrigatório sobre o produto e manifestam seus ethe sem eloquência, deixando que público os decodifique por conta própria, inclusive a partir do que podem ver através do plástico transparente.

A seguir são descritos os ethe encontrados e como eles se manifestam nas embalagens observadas.

\section{Ethos 'Ídolo': "Sou quem você quer ser."}

As embalagens de produtos como Nestlé Crunch, Carrefour Energy Adventure, Carrefour Energy Flakes, Superbom Superballs, Kellogg's Sucrilhos e Kellogg's Sucrilhos chocolate conversam diretamente com o público infantojuvenil, e o tom dessa conversa é predominantemente estimulante e 
motivacional. As mensagens verbais e não verbais de maior destaque giram em torno de temas como atitude jovem, energia, esporte, rebeldia, independência, criatividade. Com isso, a marca assume o ethos de um ídolo, um modelo a ser seguido, alguém que conhece a postura e o comportamento certos e dá o exemplo para o adolescente vencer e "se dar bem". Em seu discurso, transmite a mensagem "Seja vencedor como eu". O consumidor-alvo dessa comunicação são a criança e o adolescente fãs do ídolo, que querem crescer fortes e se destacar perante os pares.

$\mathrm{Na}$ embalagem de Sucrilhos, por exemplo, o discurso motivacional se manifesta em diversos elementos: a mascote Tony, um tigre grande, forte e amigo; as imagens de crianças praticando esportes; o troféu; as frases com termos como "garra”, "ganhar", "vitória”, “desafios”, "trabalhar duro", “inspiração”; o numeral 10 indicando o conteúdo de vitaminas e minerais (um número mais motivacional neste contexto do que seria dizer que o produto tem 8 vitaminas e 2 minerais, como se faz em outras embalagens da Kellogg) (Figura 13).

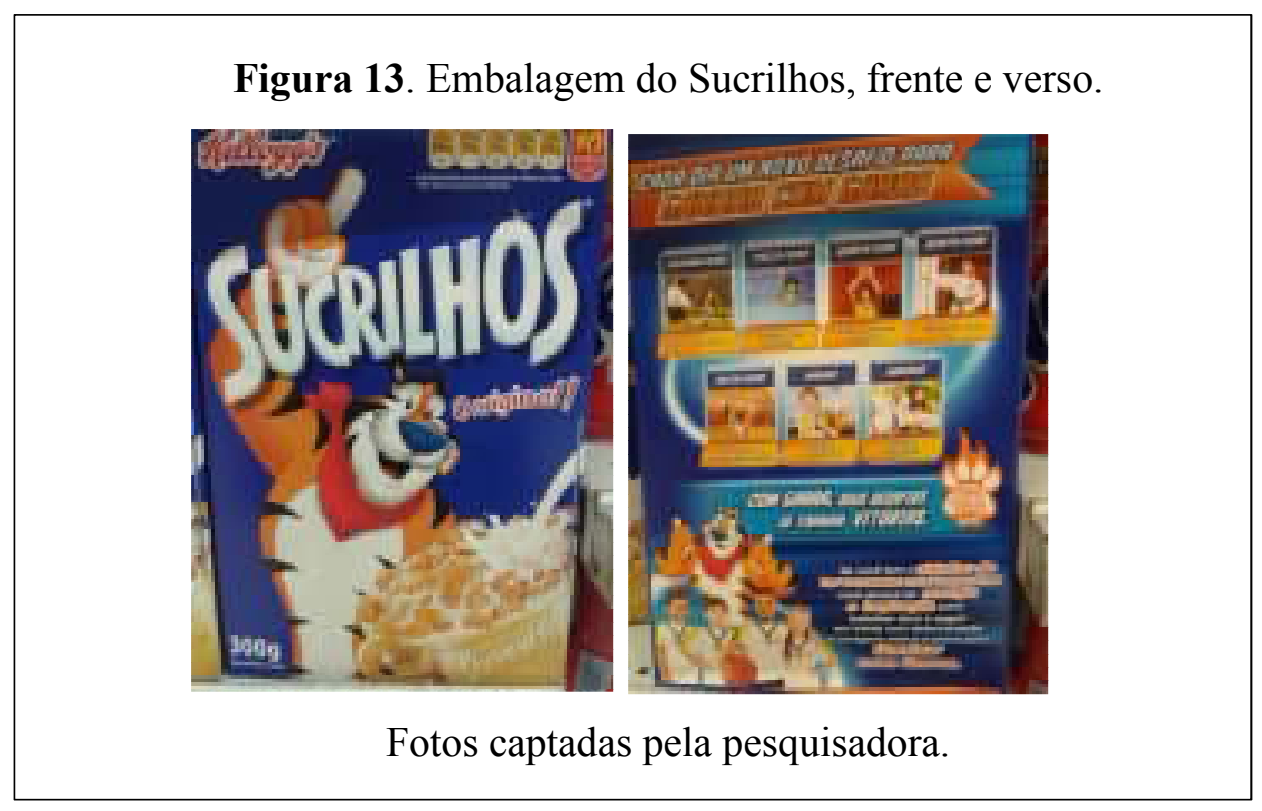

O discurso da saúde sob esse ethos está bastante associado à prática esportiva, à competitividade e ao consumo de alimentos energéticos (calóricos, ricos em carboidratos) com vitaminas.

$\mathrm{Na}$ questão ambiental, esse ethos se manifesta na maior parte dos casos por meio de um selo do FSC (Forest Stewardship Council) que avisa que a marca 
tomou o cuidado de fabricar a embalagem a partir de "fontes responsáveis". O selo pode ser lido pelo público-alvo como sinal de que a marca é exemplar no quesito responsabilidade ambiental. Nas caixas de papelão do Sucrilhos e do Carrefour Energy Flakes, o selo do FSC aparece próximo aos símbolos que indicam que a embalagem é reciclável (Figura 14). Esses símbolos também podem ser lidos como um incentivo à coleta seletiva. Assim, a marca-ídolo dá o exemplo e estende ao fã a oportunidade de seguir seus passos.

Figura 14. Detalhe da embalagem do Carrefour Energy Flakes.

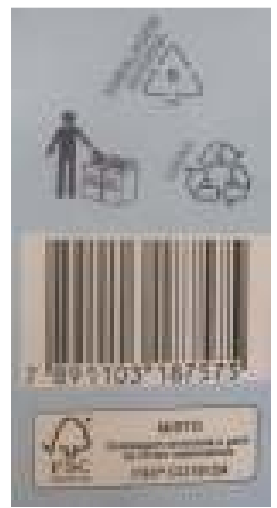

Foto captada pela pesquisadora.
Figura 15. Detalhe da embalagem do Nutry chocolate.

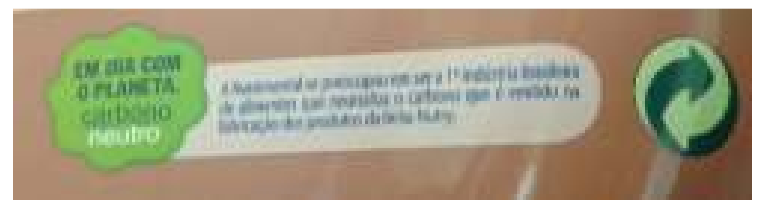

Foto captada pela pesquisadora.

O ethos ídolo na questão ambiental também pode aparecer como na embalagem do Nutry, da Nutrimental. A marca exibe seu comportamento exemplar na questão ambiental por meio de uma alegação criada por ela mesma ("Em dia com o planeta. Carbono neutro") seguida de uma explicação ("A Nutrimental se preocupa em ser a $1^{a}$ indústria brasileira de alimentos que neutraliza o carbono que é emitido na fabricação dos produtos da linha Nutry") e do símbolo Ponto Verde, uma marca registrada internacional cujos direitos de utilização são geridos pela sociedade Packaging Recovery Organization Europe (Figura 15).

$\mathrm{Na}$ Europa, o Ponto Verde indica que a empresa paga uma quantia em dinheiro para a Sociedade Ponto Verde gerir a destinação adequada dos resíduos sólidos em seu lugar (PRO EUROPE, 2014; SOCIEDADE PONTO VERDE, 2014). Em resposta a questionamento feito pela pesquisadora à empresa por meio do Serviço de Atendimento ao Consumidor (SAC), a Nutrimental informou que 
aplica o símbolo em suas embalagens "única e tão somente em razão de exigências realizadas por alguns países" para os quais exportam alguns de seus produtos.

\section{Ethos 'Especialista': "Sei do você precisa."}

Em boa parte das embalagens observadas, a marca se coloca como detentora do conhecimento científico sobre saúde e da autoridade para orientar as escolhas alimentares de seu público. O ethos especialista se manifesta na ênfase às propriedades nutricionais do produto, textos e diagramas explicativos sobre ingredientes e/ou nutrientes e até citação de estudos. Há ainda embalagens em que o ethos especialista aparece na forma de dicas de saúde e explicações sobre as propriedades dos ingredientes, muito próximas ao conteúdo de uma revista especializada, como é o caso da granola Magraça, da Frutazul (Figura 16).

A presença de informação nutricional complementar na forma de claims e de VDR é um indicativo do ethos especialista, assim como indicadores sumários, como o selo Minha Escolha. (Embora o programa Minha Escolha tenha sido descontinuado no Brasil, segundo informação obtida por e-mail com a Choices International Foundation em 3 de fevereiro de 2014, o selo foi encontrado na embalagem do Nutry Nuts.) Textos com verbos no imperativo são comuns e indicam a intenção de converter o consumidor a um determinado comportamento, geralmente uma alimentação mais consciente ou um estilo de vida mais saudável. $\mathrm{O}$ conteúdo procura convencer racionalmente. O ethos esperado para o público-alvo é o de quem se sente inseguro quanto à alimentação adequada, entende pouco ou nada de nutrição e espera receber informação e ajuda para suas escolhas.

No tema reciclagem, frases ou símbolos que atribuem ao consumidor a responsabilidade sobre a seleção dos resíduos sólidos domésticos e o descarte adequado da embalagem estão presentes sem que a marca necessariamente assuma para si sua parte da responsabilidade. É o que aparece nas embalagens da granola do Vivo, do Pura Fibra Gaiatri, dos produtos Long Life e do Kellogg's Froot Loops 
(Figura 17). A instrução de cunho unilateral pode ser interpretada como o popular "faça o que eu digo, não o que eu faço".

Figura 16. Embalagem da granola Magraça Frutazul.

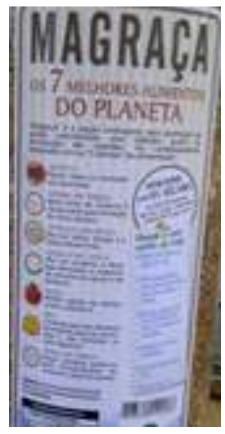

Foto captada pela pesquisadora.
Figura 17: Detalhes das embalagens da granola do Vivo, Pura Fibra Gaiatri, Long Life e Froot Loops.
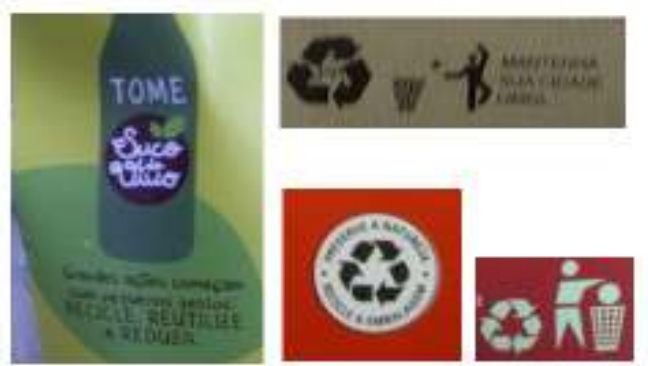

Imagens captadas pela pesquisadora.

O ethos especialista se manifesta em muitas embalagens de "cereais matinais", em alguns casos de modo mais, noutros menos homogêneo. E a predominância desse discurso não está diretamente relacionada às características do produto. Não é incomum que o discurso da ciência da nutrição apareça lado a lado com incentivos ao consumo de produtos açucarados.

Ele aparece ainda nas embalagens dos seguintes produtos: Superbom Skarchitos, Biosoft Mix de Soja, Carrefour Viver, Dia Aveia em flocos, Dia Fibramix, do Vivo, Kellness, Feinkost Liéve, Frutazul Magraça, Grings Cerealle, Jasmine Grain Flakes, Kellogg's Corn Flakes, Native Cornflakes, Native Fibras Orgânica, Nestlé Nesfit, Nestlé Corn Flakes, Nestlé Fibra Mais, Kobber Granola, Kellogg's All Bran, Quaker Granola 7 grãos, Taeq Granola Light, Trio.

\section{Ethos 'Aliado': "Busco o mesmo que você."}

O discurso das embalagens de vários produtos ditos naturais, orgânicos e afins é fortemente identitário e procura criar uma imagem positiva não apenas dos 
produtos, como também do público. O ethos esperado para o consumidor desses produtos é o de um cidadão um tanto mais consciente, informado, seletivo e idealista em relação a nutrição e sustentabilidade, na comparação com o público das grandes marcas. Assim, o ethos predominante das marcas nesses casos é o de quem tem os mesmos ideais do seu público e se esforça para fazer o bem, tanto para a saúde das pessoas quanto para o planeta. A comunicação é pensada para que o público reconheça na marca um aliado, um parceiro de ativismo, um realizador daquilo que o público não encontra no mercado dominante. A relação que se estabelece não é do tipo mestre-discípulo, mas de cooperação. $\mathrm{E}$ as responsabilidades são divididas.

No quesito ambiental, já não é só a reciclagem que aparece. O ethos aliado demonstra um interesse mais amplo em relação à sustentabilidade, em alguns casos apresenta dados comprováveis do que faz a esse respeito e ainda convida o interlocutor a conhecer melhor a história no site da empresa. Um exemplo são as embalagens da Native (Figura 18).

O discurso da saúde no ethos aliado também vai além do elogio à presença de nutrientes. Como o público-alvo desse discurso são pessoas que procuram se afastar dos produtos mais populares e se aproximar dos mais naturais, os atributos prósaúde valorizados nessas embalagens dizem mais respeito à ausência de componentes indesejáveis, como açúcar branco, aditivos artificiais ou transgênicos, à presença de ingredientes nobres e à preparação caseira. O próprio nome dos produtos e das marcas tende a refletir essa tendência a um caminho alternativo. Um exemplo é granola com amaranto Leve Crock, da Sabor Alternativo (Figura 19).

Outras marcas que adotam o ethos aliado: Mãe Terra, Monama, Gran Pure, Krun, Vida Boa, Vitao. 
Figura 18. Detalhes de embalagens Native.

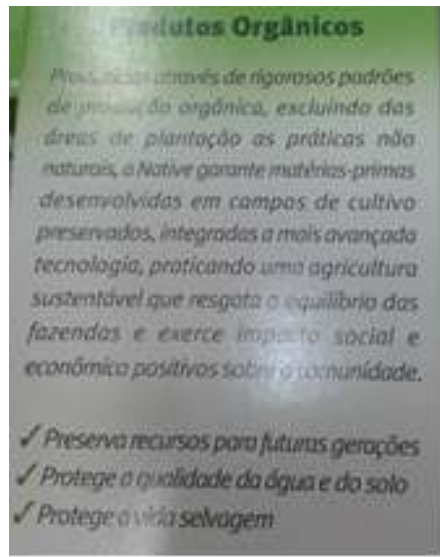

Imagens captadas pela pesquisadora.
Figura 19. Detalhe da embalagem de granola da Sabor Alternativo.

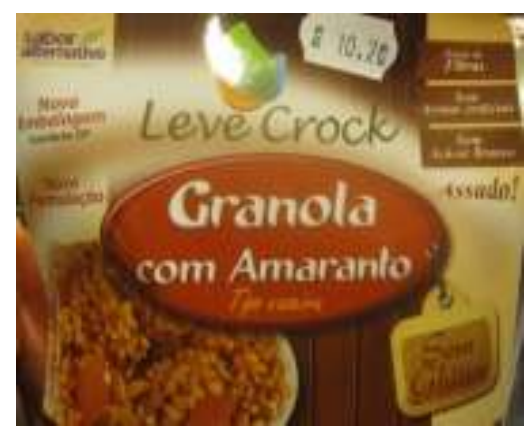

Imagem captada pela pesquisadora.

\section{Ethos 'Anfitrião festivo': "Aqui é lugar de alto astral."}

A presença de mascotes, elementos lúdicos, jogos, imagens que celebram a fartura, frases que valorizam o sabor, mensagens positivas e texturas atraentes caracterizam o ethos festivo, cuja intenção principal é atrair, agradar, alegrar, dar prazer (Figura 20). O tom da comunicação verbal e não verbal é convidativo, alegre, festivo. O ethos festivo não se preocupa com o entorno nem com o futuro e não gosta de "papo sério". Em seu discurso não há lugar para preocupações: se elas aparecerem, serão silenciadas, minimizadas, disfarçadas. O ethos do público, por sua vez, é despreocupado e fácil de seduzir. O que não é saboroso ou agradável o bastante não lhe interessa, por mais que seja saudável. O público-alvo tende a ser infantil.

A presença de açúcar e cores artificiais é declarada sem pudores e pode até ser destacada, pois o que importa é a experiência prazerosa no momento presente. 
Isso pode ser observado nas embalagens do Corn Sugar da Alca Foods, cujo nome e descrição dão destaque ao açúcar, e do Kobby Tempestade de Neve, da Kobber (Figura 21). Neste segundo exemplo, a "neve" caindo por cima dos "cereais" é justamente o açúcar.

Figura 20. Verso da embalagem do Kellogg's Froot Loops.

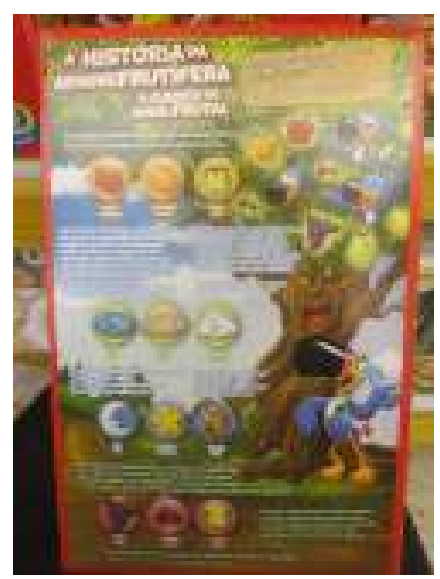

Imagem captadas pela pesquisadora.
Figura 21. Corn Sugar da Alca Foods e Kobby Tempestade de Neve.
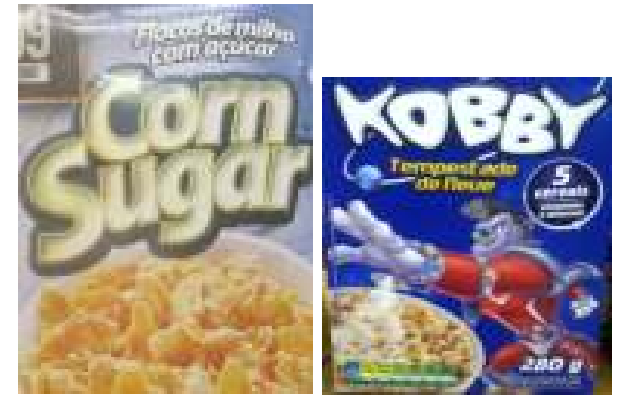

Imagens captadas pela pesquisadora.

No ethos anfitrião festivo, aspectos da sustentabilidade são silenciados ou dissimulados. É o que podemos observar na embalagem do Qualitá Ultra Flakes Açucarados, que traz na face frontal o símbolo amarelo obrigatório dos transgênicos camuflado pela cor dourada dos flocos de milho. E a enorme careta de olhos esbugalhados e língua para fora termina de apagar a presença do triângulo minúsculo. O ethos festivo nessa embalagem não pode deixar a alegria dar lugar ao medo, à insegurança, à desconfiança. Ele recebe o símbolo de alerta entre os convidados de sua festa porque foi obrigado, mas aumenta o volume da música e vai para o centro da pista fazer bagunça, para ninguém ouvir o que esse convidado $\operatorname{diz}$ (Figura 22).

Outras embalagens que manifestam o ethos festivo: Dia Cereal Bolinha, Dia Cereal açucarado e Alca Foods Choco Boll. 
Figura 22. Embalagem do Qualitá Ultra Flakes Açucarado com o símbolo dos

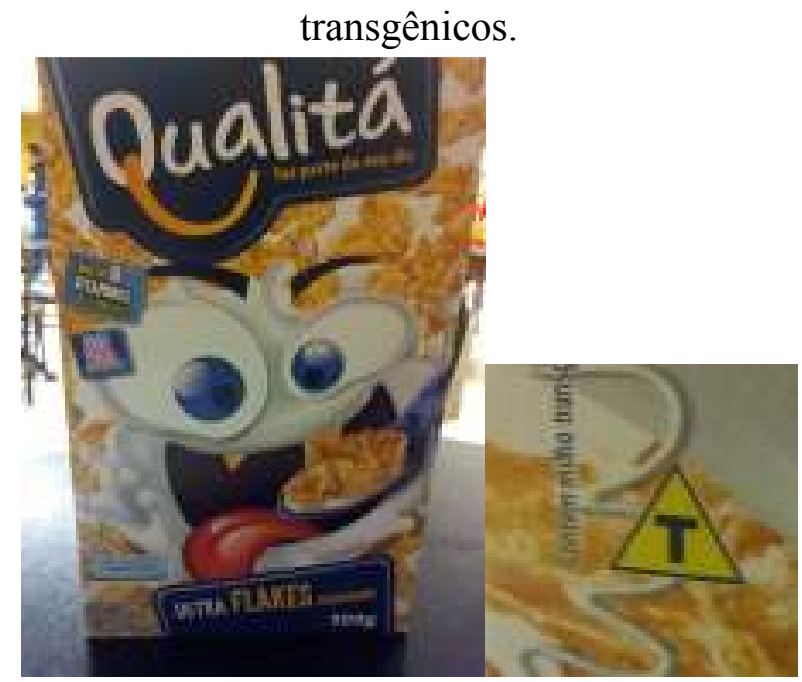

Imagens captadas pela pesquisadora.

\section{Delimitação do corpus}

Como vimos, as embalagens de "cereais matinais" observadas comunicam seu engajamento em relação a alimentação saudável, sustentabilidade e práticas de consumo a partir de quatro lugares discursivos. Elas podem se posicionar como um ídolo juvenil que orienta comportamentos a partir do exemplo. Podem ocupar o lugar de um especialista em saúde que informa e dita instruções que o público deve seguir para obter os resultados desejados. Podem ainda se colocar como aliadas na busca por um consumo consciente e um mundo melhor. Ou então podem assumir o lugar do anfitrião festivo e animado que prefere evitar preocupações em nome do prazer imediato.

Coincidência ou não, esses tipos lembram o quadrado semiótico de Floch.

A força com que as marcas ocupam esses lugares varia. Uma única marca pode adotar ethe diferentes de um produto para outro, conforme o perfil do produto e de seu público-alvo. Pode ainda adotar vários ethe numa mesma embalagem, quando seu engajamento em relação a saúde, sustentabilidade e satisfação pessoal 
não é homogêneo. Pode comunicar seu ethos com grande ênfase ou manifestá-lo sem alarde, com sutileza.

Diante dessas variações, o corpus de análise foi delineado de modo a explorar diferentes planos de expressão dos quatro ethe já caracterizados, bem como a heterogeneidade de discursos numa mesma embalagem. Assim, o corpus está composto das embalagens dos seguintes produtos, e pelos seguintes motivos:

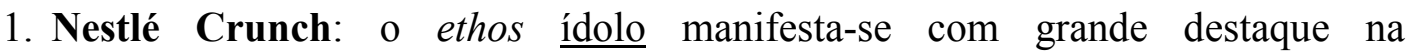
comunicação verbal e não verbal a fim de criar empatia com o público jovem. Imagem, cores, tipologia, gesto, frases e outros elementos combinados transmitem uma mensagem motivacional coesa. No quesito saúde, o ethos especialista também está presente de forma importante, incluindo marca registrada e citação de estudo científico. No conjunto, esses dois discursos geram contradições.

2. Superbom Skarchitos: o ethos especialista aparece de forma explícita na frase “Tenha um estilo de vida saudável”, que revela a intenção de converter o interlocutor a um novo padrão de escolha alimentar. E o conceito de alimentação saudável defendido está pautado na ideologia do nutricionismo.

3. Kellogg's Corn Flakes: o ethos especialista se vale de uma pirâmide alimentar para defender as supostas qualidades nutricionais do produto.

4. Granola Caseira Mãe Terra: manifesta o ethos aliado de forma homogênea e com variedade de linguagens. Usa textos, ilustrações, símbolos, selos e hipertextos para defender seu engajamento em prol da saúde, da sustentabilidade e de uma cultura de consumo alimentar mais natural.

5. Dia Cereal Açucarado: adota o ethos anfitrião festivo na forma de mascote para chamar atenção do público infantil, acalma as mães com informações rápidas sobre características nutricionais do produto e avisa sobre o conteúdo transgênico sem que isso atrapalhe a festa.

6. Dia Muesli com Frutas: comunica o mínimo necessário, sem argumentar, seduzir, dar o exemplo ou oferecer-se para nada. O nome do produto, a lista de ingredientes, a aparência real dele através de plástico transparente e o peso líquido são os parâmetros disponíveis para a escolha do consumidor. $\mathrm{O}$ discurso está na sutileza dessa comunicação. 


\section{EMBALAGEM 1 (ethos Ídolo)}

A embalagem é uma caixa de papelão em formato de paralelepípedo, de dimensões $26 \mathrm{~cm}$ x 17,5 $\mathrm{cm}$ x 5,5 cm, que normalmente fica de pé na prateleira. São seis faces, portanto. A face da caixa que fica exposta aos passantes é aqui chamada de face frontal, que funciona como uma capa de revista: traz as informações e atrativos que o fabricante deseja que sejam visualizados primeiro.

\section{Percurso de leitura}

O olhar é atraído primeiramente para a inscrição "Crunch", nome do produto (Figura 23). É a palavra da face frontal que está escrita com a maior fonte, em caixa alta, com profundidade, em cor vermelha sobre uma tarja branca, por sua vez sobreposta em fundo liso azul-escuro, o que confere grande destaque ao nome do produto. A inscrição e a tarja branca não são horizontais: ambas estão "quebradas ao meio", formando um ângulo obtuso.

Figura 23. Nestlé Crunch, face frontal. No detalhe, rotulagem nutricional frontal em formato VDR.

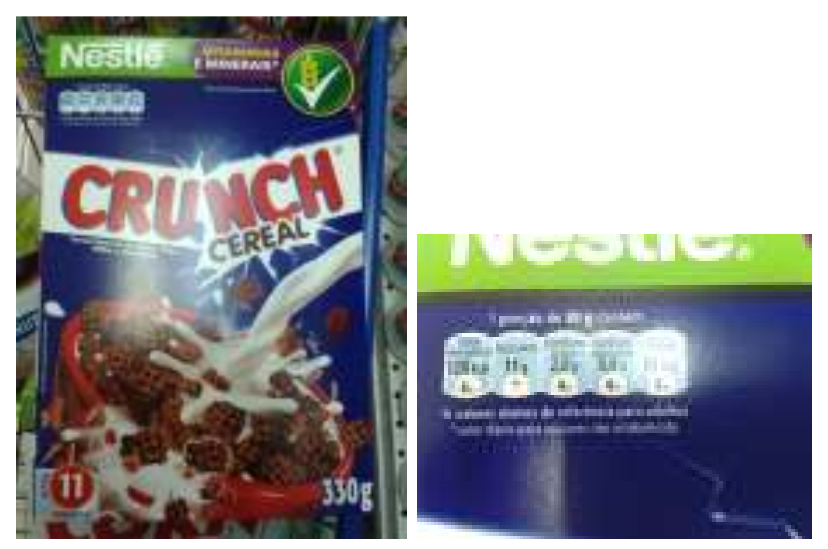

Imagens captadas pela pesquisadora em dez 2012. 
“Crunch” não é uma palavra na língua portuguesa. Na língua inglesa, designa a crocância do alimento. No contexto da embalagem, refere-se portanto à sensação tátil e auditiva proporcionada pela mastigação do produto dentro da caixa. Para o consumidor brasileiro que desconheça o termo, a embalagem oferece um signo visual que também remete ao ato de quebrar: uma ilustração por trás do nome "Crunch" e sobre o fundo azul-escuro da face frontal assemelha-se a uma grande rachadura numa parede.

O olhar é atraído para baixo, onde a ilustração continua, mantendo o contraste entre as cores azul-escuro, vermelho e branco. Ali, logo abaixo da inscrição "Crunch", está a figura de uma tigela vermelha cheia de gomos do "cereal Crunch" sendo súbita e violentamente atingidos por um jorro de leite branco. Espirram gomos para fora da tigela. Estilhaços da própria tigela, quebrada, são projetados para fora, lembrando uma explosão. A ilustração permite captar a ideia de abundância, fartura, uma explosão de crocância.

O terceiro elemento da face frontal da embalagem que mais chama atenção está em sua margem superior, à esquerda. Uma tarja verde de 2,5 cm de largura destaca a inscrição "Nestlé®”, grafada em fonte branca. A marca Nestlé é conhecida e há de ser imediatamente reconhecida pelo consumidor brasileiro, que convive com ela desde a primeira metade do século XX.

Ao lado direito da inscrição "Nestlé ${ }^{\circledR} "$, há a inscrição "Vitaminas e minerais*", com asterisco, em fonte menor, caixa alta, separada em suas linhas, nas cores amarelo ("vitaminas") e branco ("e minerais"), sobre uma cantoneira roxa de extremidade arredondada. $\mathrm{O}$ asterisco refere-se a uma inscrição localizada fora e abaixo da tarja roxa, em fonte muito menor, branca sobre o fundo azul-escuro, apenas com iniciais maiúsculas, que diz “*Rico em 8 Vitaminas, Ferro e Zinco.”.

Ao lado da inscrição "vitaminas e minerais*", sobrepondo em parte a cantoneira roxa e em parte o fundo azul-escuro, há um selo circular de quatro centímetros de diâmetro, de interior verde e borda amarela, dentro do qual está um pictograma em branco e amarelo, que representa uma rama de trigo acompanhada de um check mark.

A explicação do significado do selo não está localizada na face frontal da embalagem, mas na face superior. Ela será abordada mais adiante. 
Ainda na face frontal, abaixo da tarja verde sobre a qual se inscreve a marca "Nestlé", está uma pequena tabela horizontal, em azul-claro com bordas brancas, sobre o fundo liso azul-escuro, em que é apresentada parte da composição nutricional do produto (Figura 23). A tabela informa, por meio de numerais e medidas-padrão, quantas calorias e quantos gramas de açúcares, gorduras totais, gorduras saturadas e sódio contém uma porção de 30 gramas do "cereal Crunch". Cada quantidade informada está associada a um percentual.

A tabela azul-clara é uma rotulagem nutricional frontal facultativa do tipo VDR, que apareceu pela primeira vez no Reino Unido e vem sendo cada vez mais usada na União Europeia (UE). Ela representa os níveis de ingestão diária de nutrientes que supostamente a maioria das pessoas deveria ser orientada a consumir para uma dieta saudável. A Confederação das Indústrias Agroalimentares da UE (CIAA) propôs esse modelo para a rotulagem nutricional em todos os países do grupo (IOM, 2010, p. 97). Trata-se de uma abordagem da nutrição e de uma linguagem incorporadas pelo discurso da indústria de alimentos, que reforça e dá continuidade a uma visão da alimentação focada nos nutrientes.

Abaixo da tabela, a inscrição “\% valores diários de referência para adultos", em fonte branca negritada e diminuta, explica que percentuais são esses. No lugar do percentual das necessidades diárias de açúcares, há um asterisco, que leva a uma inscrição em fonte branca e ainda mais diminuta e sem negrito que diz "valor diário para açúcares não estabelecido". Os sentidos desta última frase serão detalhadamente abordados no tópico "Texto x números".

No canto inferior esquerdo da face frontal, o numeral 11, inscrito em branco dentro de um círculo vermelho e acompanhado das inscrições "rende" (na vertical) e "porções" (na horizontal), sobre cantoneira azul-clara, indica o número de porções de 30 gramas contidas na embalagem. No canto inferior direito, informa-se o conteúdo líquido da embalagem: 330 gramas.

Menos destacada na face frontal da embalagem está a inscrição "Cereal Matinal de Arroz, Trigo, Milho e Chocolate", em branco sobre fundo liso azulescuro, com iniciais maiúsculas, logo abaixo do nome do produto. Trata-se de uma descrição simplificada do produto. 
$\mathrm{Na}$ borda esquerda da face frontal, na vertical, está a inscrição mais discreta de toda a face frontal: "Leite ilustra sugestão de consumo", em fonte diminuta, branca com negrito, sobre fundo liso azul-escuro. Há grande probabilidade de o consumidor não notar essa inscrição.

\section{Sentidos gerados pelas imagens}

A face frontal, conforme dito anteriormente, exibe as informações e os atrativos que a marca deseja que o consumidor visualize primeiro no momento em que examina os produtos na gôndola do supermercado. Assim como a capa de um livro na vitrine de uma livraria ou a capa de uma revista numa banca, a face frontal da embalagem tem a função de chamar a atenção dos passantes e conquistar seu interesse.

O que salta aos olhos na "capa" da embalagem do "cereal Crunch" é a força da "cena" presente na ilustração aliada ao significado do nome do produto. A iconografia dessa parte da embalagem transmite não somente a crocância do produto, mas principalmente a ideia de quebra, de ruptura, de ruído irrompendo na calmaria. Com esse plano de expressão, a marca Crunch ${ }^{\circledR}$ se associa a um desejo de "quebrar tudo", de romper com a mesmice, com o passado, com limites preestabelecidos.

Outras interpretações podem ser extraídas dessa imagem. A tigela vermelha estava cheia até a boca com "cereal Crunch" antes que o jorro de leite viesse tomar seu lugar e "expulsasse" alguns gomos para fora. A força de destruição, o poder de ruptura, parece vir do leite. É a partir da chegada do leite que tudo transborda, como uma represa que extrapola sua capacidade para reter líquido. O leite vem inundar um recipiente que já estava cheio até a boca e que já não comportará seu novo conteúdo.

Já a partir da análise da face frontal da embalagem de Crunch é possível perceber que ela foi pensada para gerar vínculos de sentido com seu público-alvo: 
os adolescentes. Adolescentes que poderão se definir como crianças que estão crescendo e, assim como o cereal da ilustração, já não cabem nos "recipientes" apertados de antes. Já não cabem nas roupas, nem nas brincadeiras, nem nos valores, nem nas relações familiares e sociais da infância. O adolescente aí colocado como leitor ideal dessa embalagem é um ser em expansão, que precisa buscar e estabelecer para si mesmo novos limites. Se vestir as roupas que the cabiam quando criança, elas irão rasgar. Se tentarem contê-lo dentro dos limites comportamentais estabelecidos pelos adultos para as crianças, ele poderá “explodir". O momento identitário desse adolescente é o de romper com um passado deveras limitado e crescer.

Conforme diversos estudos sugerem (HARRIS et al, 2009), as marcas fazem parte da formação da identidade de crianças e adolescentes. Assumindo que o adolescente vive uma fase da vida em que é facilmente rotulado, julgado e condenado pelos pares quando não se comporta conforme os padrões estabelecidos pelo grupo dominante, Crunch se apresenta a esse público como um aliado, um melhorador de imagem, um salvador que vai tirar o adolescente do sofrimento social. Seu ethos é o de um ídolo.

\begin{abstract}
Por uma marca apreciada, o jovem sai da impessoalidade, pretende mostrar não uma superioridade social, mas sua participação inteira e igual nos jogos da moda, da juventude e do consumo. Bilhete de entrada no modelo de vida 'moda', é o medo do desprezo e da rejeição ofensiva dos outros que ativa a nova obsessão pelas marcas. À hora do hiperconsumo, é preciso apreender esse fenômeno como uma das manifestações do individualismo igualitário que conseguiu estender suas exigências até o universo imaginário dos jovens. (...) A verdade é que, ao comprar esta ou aquela marca, o adolescente faz uma escolha que o distingue do mundo de seus pais, ele afirma preferências e gostos que o definem, apropria-se de um código. (...) Exibida essa marca em público, o adolescente nela reconhece uma das bandeiras de sua personalidade (LIPOVETSKY, 2007, p. 50-51).
\end{abstract}

Convém lembrar que a Nestlé também é marca de leite, e o incentivo ao consumo de leite na embalagem de um cereal não há de ser mera coincidência. Mas não esqueçamos que essa imagem tem uma grande carga simbólica. O jorro de leite representa o próprio alimento leite, a ser consumido em abundância, mas também pode remeter à força da mudança que faz expandirem os limites da vida do adolescente. Força na forma de hormônios sexuais, talvez. Na forma de força física. $\mathrm{Na}$ forma de um senso crítico que começa a florescer. 
Logo acima, o selo circular com o pictograma que combina a rama de trigo com o check mark, junto com a inscrição "vitaminas e minerais*", traz em si uma aprovação. No conjunto, esses elementos avisam que, nutricionalmente, o produto está OK. A rama de trigo representa o alimento à base de cereal, enquanto o check mark simboliza a adequação do produto a um determinado parâmetro de qualidade nutricional. Seja lá qual for esse parâmetro e quem o estabeleceu, a mensagem é que "alguém" garante que o produto é nutritivo, afinal há ali um "selo" atestando essa informação. Mais adiante será discutido quem é esse alguém.

\section{Sentidos gerados pelos números}

Menos abstrata que o selo pictórico, a pequena tabela azul-clara com informação nutricional parcial seleciona a parte da informação nutricional obrigatória que supostamente será mais interessante para o público-alvo. A informação completa - a tabela nutricional - está impressa numa face lateral da embalagem, que não está visível para quem passa no corredor do supermercado. Então a face frontal traz um excerto, numa lógica de seleção de informações parecida com a de uma revista que coloca na capa frase de efeito de um entrevistado da edição.

A tabela nutricional completa informa quantidades de 21 itens, enquanto a tabela pequena da face frontal engloba apenas cinco. Os cinco itens selecionados para a "chamada de capa" foram: calorias, açúcares, gorduras totais, gorduras saturadas e sódio. A mensagem da marca com essa seleção é que, do ponto de vista nutricional, são as quantidades desses itens que fazem a diferença.

O tamanho em que os signos aparecem em qualquer material impresso é revelador da importância que o emissor das mensagens dá a cada uma delas. Tamanhos indicam hierarquia. Tomando-se o tamanho da fonte como parâmetro de comparação, podemos inferir que o enunciador considera que a simples presença de vitaminas e minerais no produto é mais importante do que a quantidade de calorias, 
açúcares, gorduras e sódio, ainda mais importante que a quantidade em que esses nutrientes estão presentes, e muito mais importante que a origem desses nutrientes, que só será revelada na lista de ingredientes.

Em livros e outras publicações, o asterisco é geralmente utilizado para indicar que uma informação complementar foi adicionada à margem do texto, em outra parte da mesma página, para que os leitores não interessados em uma leitura mais aprofundada não precisem interromper a leitura do texto principal e possam seguir em frente sem ler o rodapé, se não quiserem. Na embalagem do "cereal Crunch", duas inscrições assinaladas por asterisco foram adicionadas dentro da "margem", mas com fontes diminutas: 1) o número de vitaminas e o nome dos minerais anunciados em caixa alta; e 2) o aviso de que não há valor diário estabelecido para o consumo de açúcares.

$\mathrm{O}$ uso de asterisco na coluna dos percentuais das necessidades diárias (\%VD) nas tabelas nutricionais das embalagens de alimentos é comum. Normalmente, avisa-se no pé da tabela que não há valor diário estabelecido para o nutriente em questão. Mas na embalagem do "cereal Crunch" o asterisco foi usado também para conduzir a leitura a uma informação que nem sempre é considerada secundária, menos importante ou tão dispensável por coenunciadores menos interessados. Em embalagens de "cereais matinais" de outras marcas que compõem o corpus exploratório deste trabalho, essa mesma informação sobre a presença de oito vitaminas no produto aparece com maior destaque, possivelmente com a intenção de dizer que o produto tem bastante vitamina e, portanto, é nutritivo. Podemos inferir que, no caso do "cereal Crunch", é mais importante para a marca comunicar a presença de vitaminas e minerais do que detalhar quantas vitaminas o produto contém ${ }^{\mathrm{f}}$.

Isto talvez se deva ao perfil do público-alvo. LIPOVETSKY (2007) batizou de 'a era do hiperconsumo' esta época em que vivemos, iniciada no fim dos anos 1970, em que o consumo tornou-se o grande norteador das atividades humanas. Diante de uma gama de escolhas pessoais nunca antes vista, teríamos passado "de um consumo ordenado pela família a um consumo centrado no indivíduo", da

${ }^{\mathrm{f}}$ Ver adendo no fim deste tópico. 
escolha para a hiperescolha, do consumo individualista para o consumo hiperindividualista (p. 104). "Cada um com seus objetos, cada um com seu uso, cada um com seu ritmo de vida" (p. 105). Para o autor, "a evolução dos comportamentos alimentares é particularmente exemplar" dessa individualização. "Enquanto a oferta é mais variada e mais exótica, os cardápios, os horários, os lugares da refeição dependem de escolhas muito mais pessoais que de regras coletivas: ei-nos à hora da desestabilização do sistema das refeições e da alimentação desestruturada" (p. 105).

Em sendo a comunicação mercadológica direcionada aos interesses específicos do público-alvo, podemos deduzir que, no entendimento da marca, o público-alvo do "cereal Crunch" contenta-se em saber que o produto contém vitaminas e minerais e não se importa em saber quanto.

As quantidades que a marca supõe serem importantes para seu público-alvo estão expressas em numerais destacados ao pé da face frontal da embalagem. Do lado esquerdo, informa-se com destaque visual que a embalagem rende 11 porções do "cereal Crunch". O coenunciador pode interpretar essa informação da seguinte forma:

Esta embalagem rende 11 porções.

Esta embalagem rende mais de dez porções.

Posso consumir esse produto mais de dez vezes.

Esta embalagem rende bastante.

A informação sobre o tamanho da porção (30 gramas), no entanto, aparece distante no número de porções, em fonte bem menor, acima da pequena tabela azulclara. De forma mais discreta, a face frontal da embalagem informa que a porção sugerida para o consumo individual do produto é de 30 gramas. Somente na lateral da embalagem, dentro da tabela nutricional, será esclarecido que essa porção equivale a $3 / 4$ de xícara.

O tamanho da porção não é aleatório, pois faz parte das informações controladas pela legislação. Uma porção de qualquer alimento embalado é definida pela Resolução RDC no 360, de 23 de dezembro de 2003, como "a quantidade média do alimento que deveria ser consumida por pessoas sadias, maiores de 36 meses, em cada ocasião de consumo, com a finalidade de promover uma 
alimentação saudável" (ANVISA, 2003). O mesmo documento determina que o tamanho da porção deve ser definido conforme os critérios do Regulamento Técnico de Porções de Alimentos Embalados. Este regulamento técnico adotou como base uma alimentação diária de 2000 quilocalorias, uma classificação dos alimentos em níveis e grupos, o valor energético médio de cada grupo, o número de porções recomendadas para cada grupo e o valor energético médio correspondente a cada porção (MERCOSUL, 2003). A Figura 24 ilustra como se chega a esse valor.

Figura 24. Metodologia indicada para determinar o tamanho da porção.

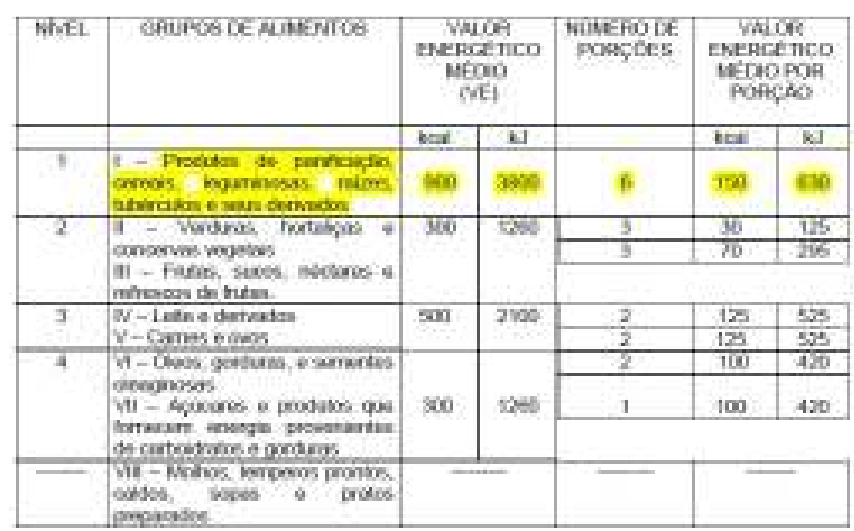

Extraído de: MERCOSUL (2003).

Na tabela azul-clara, no lugar do valor diário estabelecido para açúcares, há um asterisco. Um dos sentidos gerados por essa tabela é que existem valores diários estabelecidos para o consumo de energia, gorduras totais, gorduras saturadas e sódio, mas não para açúcares. Analisemos a frase "valor diário para açúcares não estabelecido" por meio da paráfrase.

Valor diário para açúcares não estabelecido.

O valor diário para o consumo de açúcares não está estabelecido.

O valor diário para o consumo de açúcares ainda não foi estabelecido.

O valor diário para o consumo de açúcares poderia ter sido estabelecido, mas não foi.

Não existe valor estabelecido para o consumo diário de açúcares.

O consumo de açúcares está livre de valor diário estabelecido.

O consumo de açúcares é livre. 
No contexto da tabela, a inscrição permite a seguinte interpretação: Existem limites recomendados para o consumo de energia, gorduras totais, gorduras saturadas e sódio, mas o consumo de açúcares é livre.

Assim, é possível observar que, nas embalagens, a objetividade pretendida da linguagem matemática pode sofrer a interferência de outros elementos da mensagem.

\section{Sentidos conflitantes gerados por imagem e números}

No percurso de leitura descrito anteriormente, vimos que a imagem da tigela transbordante é potencialmente um dos primeiros elementos a atrair o olhar do público. A imagem transmite a sensação de abundância, de exagero até. A sensação de tamanho da porção transmitida pela imagem não corresponde ao tamanho da porção individual sugerida na tabela nutricional. Enquanto a imagem sugere o consumo de "uma tigela transbordando e explodindo de tão cheia", a tabela nutricional sugere o consumo de "menos de uma xícara".

Vimos também que o simbolismo dos recursos visuais da embalagem gera sentidos com potencial para gerar vínculos de identidade entre a marca e o consumidor-alvo. Se essa estratégia de comunicação funciona, então é lógico pressupor que o consumidor-alvo irá se identificar com a ideia de encher sua tigela até a boca e consumir o produto com ímpeto, em vez de buscar a diminuta orientação da tabela nutricional e consumir apenas $3 / 4$ de xícara por vez.

Eis aí uma ambiguidade. Ou a tigela é farta, ou a porção é de 30 gramas. Ou o consumidor limita-se a consumir a porção sugerida na tabela nutricional e desfruta da prometida rentabilidade do conteúdo líquido da embalagem, ou ele se entrega ao comportamento antilimites que a linguagem de maior impacto da embalagem lhe sugere.

Se assumimos que o consumidor-alvo se identifica com a marca e tende a se comportar conforme os valores da marca, comunicados com linguagem visual de 
impacto, podemos inferir que a sugestão de consumo trazida na tabela nutricional será interpretada pelo coenunciador como mensagem secundária, silenciável, passível de ser ignorada. Se a porção sugerida de 30 gramas não é a porção desejada nem efetivamente consumida, então a informação nutricional oferecida na face frontal da embalagem não é aproveitada pelo coenunciador. Logo, não tem importância, não é útil.

Não ignoremos, no entanto, a hipótese de consumidores mais atentos inverterem o percurso da leitura da embalagem pretendido pela comunicação de marketing da marca. Um leitor não idealizado pela marca poderá ignorar ou minimizar o impacto da comunicação visual da embalagem e concentrar-se na informação nutricional. Mas há produtos mais atraentes para esse público, como veremos mais adiante, e é provável que o "cereal Crunch" não interesse a ele.

\section{Sentidos gerados pela marca}

O contexto de comercialização do produto permite inferir que o termo "cereal" nessa embalagem é utilizado para identificar a categoria do produto dentro do varejo. Nos supermercados visitados durante a pesquisa, o produto estava posicionado próximo a outros produtos feitos com ingredientes semelhantes, de textura crocante, e cuja sugestão de consumo envolvia uma tigela com leite e/ou frutas. Em algumas lojas, o corredor de exposição do produto era identificado como o setor dos "cereais matinais".

Como designação de categoria de produto, o termo "cereal" sinaliza a existência de um conjunto de produtos, de número indefinido, que se destinam a um mesmo modo de consumo, que se inserem num mesmo padrão de comportamento cotidiano. São produtos embalados em saco plástico, às vezes dentro de uma caixa de papelão, de formato granulado, textura crocante, sabor doce, para serem derramados numa tigela funda sobre uma mesa, molhados com leite suficiente para cobrir uma porção, levar à boca com uma colher e mastigar na hora do desjejum. 
"Cereal" é, assim, a identidade coletiva dos produtos feitos para serem consumidos dessa forma. Os significados do termo "cereal" são histórica, cultural e mercadologicamente construídos.

Essa memória vem do final do século XIX, quando o médico John Harvey Kellogg, preocupado com a saúde dos americanos, abriu um spa ("sanatorium") vegetariano em Battle Creek, perto de Detroit, e adotou para seus clientes uma dieta a base de grãos integrais, em que o sal e o açúcar eram malvistos. Um dos itens do cardápio eram flocos de trigo que ele mesmo desenvolveu. As operações de produção dos flocos ficavam a cargo de uma segunda empresa, a Sanitas Nut Food Company, assumida por seu irmão mais novo, Will Kellogg. As vendas do produto teriam chegado a 50 mil quilos em 1896. Então os irmãos resolveram produzir também flocos de milho, que chamaram de Sanitas Toasted Corn Flakes (MOSS, 2013, p. 68-70).

Enquanto isso, um cliente do spa chamado C. W. Post, inspirado pela criação dos Kellogg, planejava tornar-se concorrente dos irmãos. Em 1892, Post abriu uma empresa que, entre outros itens, vendia flocos de milho doces chamados Post Toasties. Post gastou milhões de dólares com propaganda, o que, segundo um artigo da revista Collier's citada por MOSS (2013), incluía o endosso de falsos médicos e promessas de cura (p. 71).

Em 1906, numa traição quase bíblica, Will aproveitou uma viagem de John Harvey para adicionar açúcar aos cereais. Os pacientes do spa gostaram muito, mas John Harvey ficou furioso, e a sociedade entre os irmãos se desfez. Will então lançou outra linha de flocos de milho, esta açucarada, que chamou de Kellogg's Toasted Corn Flakes. A briga entre os irmãos foi parar na justiça, e Will ganhou os direitos comerciais sobre o uso do sobrenome da família. Em 1922 nascia a Kellogg, fundada por Will Kellogg, que também passou a usar a propaganda a seu favor. E assim começava a história do café da manhã doce, cujos teores de açúcar aumentavam à medida que a concorrência entre as principais empresas atuantes no setor no início do século XX se acirrava. O açúcar estava até no nome dos produtos: Sugar Corn Pops, Sugar Frosted Flakes, Sugar Smacks, Sugar Smiles, Sugar Jets (MOSS, 2013, p.70-71). 
MOSS (2013) relata que na década de 1980 nos Estados Unidos 66\% das mulheres entre 25 e 44 anos - a faixa de idade em que boa parte delas tendia a ter crianças - trabalhavam fora de casa, o que transformava o café da manhã numa ocasião quase tão estressante para elas quanto o jantar. Para a crescente indústria de "cereais matinais", essa era uma oportunidade imperdível. "Conveniência era a chave para começar o dia”, resume o autor.

A quantidade de açúcar nos "cereais" não passou despercebida entre profissionais de saúde. Num artigo de 1975 intitulado Is it cereal or candy? (É cereal ou confeito?), citado por MOSS (2013, p. 74-75), o professor de nutrição de Harvard Jean Mayer dizia que esses produtos deveriam ser rotulados como imitação de cereal ou confeitos de cereal e vendidos na seção de doces, não na de cereais. Inicialmente, a indústria, reagiu à campanha da saúde retirando o açúcar do nome dos produtos, sem retirá-lo da composição. Em 1985, a Post também trocou nomes de produtos ao reconhecer que havia uma "sensibilidade à palavra açúcar", mudança que foi considerada pela empresa como "uma ferramenta de marketing para dar uma imagem moderna a um produto antigo" (p.82). Mas a pressão crescia e era preciso encontrar novas maneiras de vencer a concorrência e atender ao mesmo tempo às exigências do paladar e de saúde do público.

Nos anos 1990 os profissionais de marketing já eram mais cruciais do que os engenheiros de alimentos dentro da Kellogg, pois nessa época as marcas já tinham grande valor. Cada produto da Kellogg tinha sua própria identidade, construída por meio de milhões de dólares gastos com publicidade. "Cada marca tinha sua própria imagem para transmitir. Corn Flakes sugeria tradição. Frosted Flakes, diversão. Special K, nutrição e força" (MOSS, 2013, p. 85). No desenvolvimento de novos produtos, era mais importante encaixar o sabor no conceito da marca do que alcançar o melhor sabor.

A embalagem de Crunch, assim como as de outros produtos Nestlé observadas na pesquisa exploratória, procura diferenciar o produto em relação à concorrência chamando atenção para a existência de "cereal integral" em sua composição. É a isso que se refere o selo com o check mark descrito anteriormente, conforme a explicação que se apresenta na face superior da caixa, que tem menos chance de ser percebida pelo consumidor no momento da compra do que já dentro 
de casa, à mesa do café da manhã, uma vez que a face superior da caixa torna-se sua aba de abertura e fechamento no momento do consumo.

Ali o pictograma se repete, acompanhado da seguinte inscrição (negritos e caixas altas conforme a embalagem): "Este símbolo garante que seu cereal NESTLÉ® é feito com Cereal Integral. Nem todos os cereais são feitos com Cereal Integral. Procure este símbolo.” Chama atenção o uso do negrito e de iniciais maiúsculas no termo "cereal integral".

Tais elementos, associados à existência do selo e sua aplicação nas embalagens (esta e outras) de produtos da marca Nestlé, caracterizam o ingrediente "cereal integral" também como uma marca. Uma marca a ser reconhecida, procurada, verificada e até exigida pelo consumidor. Com efeito, o selo é uma marca registrada, o que se pode confirmar pelo símbolo ${ }^{\circledR}$ que aparece logo ao lado dele na face frontal. Assim estabelece-se um vínculo de confiança entre a Nestlé e o consumidor, de quem a marca espera que assuma uma postura exigente diante da presença de cereal integral nos cereais matinais.

Originalmente, o termo "cereal" designa uma família de plantas que produzem sementes ou grãos capazes de suprir as necessidades energéticas de animais e seres humanos quando cozidos ou processados e usados em preparações culinárias. De acordo com essa definição, são considerados cereais o trigo, o milho, o arroz, a aveia, a cevada, o centeio, entre outros.

O uso do termo "cereal" na embalagem confunde os significados, induzindo o consumidor a crer que produtos crocantes e doces a serem consumidos numa tigela com leite equivalem a grãos integrais e outras fontes de carboidratos complexos. Ao usar o mesmo termo para alimentos de graus de processamento e sabores distintos, as embalagens dificultam a diferenciação entre eles. Com veremos mais adiante, há embalagens que posicionam uma tigela de "cereal matinal" com leite na base da pirâmide alimentar.

Percebemos então que há três sentidos para o termo "cereal" presentes nessa embalagem: 1) cereal como categoria de produto, 2) cereal como alimento e 3) cereal como marca. No conjunto da mensagem, constrói-se o conceito de "cereal Nestlé”, um nome novo que funde os três sentidos num só. Em vez de explicitar as 
diferenças entre produto e alimento, entre processado e integral, entre marca e concretude, o discurso da embalagem apaga essas variações.

\section{Sentidos gerados pelo texto}

Uma das faces laterais da embalagem explicita a sugestão de consumo do produto, incluindo um endosso da classe de nutricionistas. A frase "Comece o seu dia detonando" sugere que o produto seja consumido como desjejum e é seguida de "As nutricionistas sugerem: café da manhã com cereal e leite + uma fruta ou suco." Logo mais vem um reforço: “Turbine seu café da manhã com Crunch ${ }^{\circledR}$ cereal e leite.”, seguido de uma sugestão de consumo figurativa (Figura 25). Os verbos no modo imperativo ("comece", "turbine") associados a uma instrução atribuída a nutricionistas indicam presença do ethos especialista concorrendo com o ethos ídolo na mesma embalagem.

A sugestão de consumo é ainda mais reforçada por um texto na outra face lateral da embalagem, em que se lê (negritos e caixa alta conforme a embalagem): "Nutrientes essenciais (como vitaminas e minerais) que não consumimos no café da manhã geralmente não são compensados nas outras refeições do dia. Essa é uma das razões por que o café da manhã é uma refeição FUNDAMENTAL para uma alimentação balanceada. FONTE: GIBSON ET AL., 1995; PRESIOSI ET AL., 1999; CHO’S ET AL., 2003.” (Figura 25).

Três artigos científicos são citados para endossar a afirmação de que o desjejum é uma refeição importante, o que coloca a marca no lugar do próprio especialista, detentora de um conhecimento que a legitima para orientar as decisões de seu público.

O plano de expressão combina mensagem textual e icônica para reforçar o plano do conteúdo, que avisar que não comer "cereais matinais Nestlé" de manhã significa não fazer uma alimentação balanceada, ou que café da manhã com “cereais matinais Nestlé” é fundamental para uma alimentação balanceada. E, 
segundo esse discurso, o que torna a alimentação balanceada são os nutrientes presentes no produto. Trata-se de um discurso carregado com a ideologia do nutricionismo, que promove uma imagem positiva ou negativa dos alimentos com base na presença de nutrientes "bons" e/ou no baixo teor de nutrientes "maus", desconsiderando aspectos como o grau de processamento, a procedência dos ingredientes, os modos de produção ou a adição de aditivos alimentares não nutritivos.

Figura 25. Detalhes das laterais da embalagem de Nestlé Crunch.

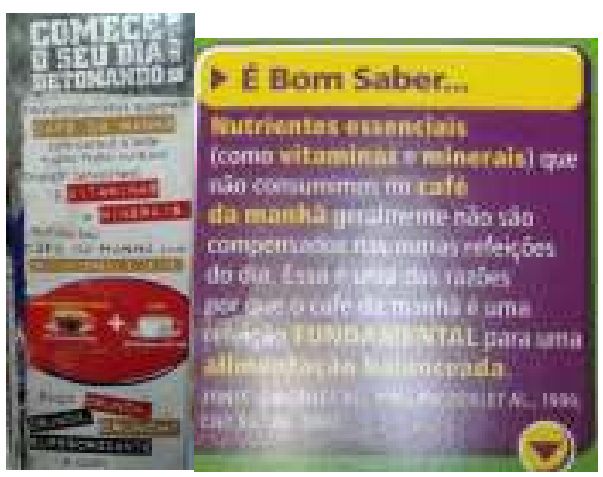

Imagens captadas pela pesquisadora em dez 2012.

Segundo SCRINIS (2013), essa ideologia é também um paradigma reducionista que tem moldado a pesquisa em ciência da nutrição desde o século XIX e servido de referência para recomendações nutricionais, regulação de rotulagem de alimentos e práticas de marketing, além do próprio entendimento que o público tem dos alimentos (p. 2). O autor diz que o nutricionismo funciona como ideologia pelo modo profundo como formata o entendimento e a experiência do público leigo em relação aos alimentos, já que as alegações de saúde e de conteúdo de nutrientes do marketing de alimentos se tornaram a principal fonte de informação nutricional (p. 13, 211). “Consumidores nutricêntricos são também mais abertos e responsivos às práticas de marketing nutricional das indústrias de alimentos, suplementos alimentares e dietas de perda de peso" (p. 13).

Embora assuma o lugar do especialista em nutrição, o sujeito desse discurso se constrói também sobre uma memória afetiva que constitui a cultura do adolescente: a memória do cuidado materno. A voz da mãe que diz ao filho o que 
faz bem, que o manda comer direitinho, que dá conselhos durante o café da manhã, que quer que ele cresça saudável, forte e esperto está presente no interdiscurso, delimitando os dizeres que serão aceitos por esse consumidor, que quer crescer mas ainda está afetivamente ligado à mãe. $\mathrm{Na}$ visão da criança, quem sabe tudo é a mãe. E agora, diante desse adolescente que quer ser independente, a Nestlé traz um discurso parecido, revestido de ciência e irreverência, construído como se fosse novo por meio do esquecimento ideológico da voz materna.

\section{Discurso da marca e vínculos de sentido}

O exame da face posterior dessa embalagem confirma o que foi observado na face frontal. De forma mais explícita, verbal e figurativamente, a mensagem reforça o que a "capa" do produto sugeria.

A palavra "movimento", grafada no topo de uma folha de papel branca em caixa alta, cor vermelha e tipografia forte, lembra a linguagem de panfletos politizados. É ela que encabeça a mensagem. A embalagem torna-se manifesto. Ao centro, uma mão jovem empunha uma colher num gesto que lembra o de um revolucionário armado, ao lado de tarjas que mimetizam etiquetas impressas em relevo. À esquerda, um alto-falante e um plug de microfone completam a caracterização do "cenário" de uma manifestação de rua (Figura 26).

As etiquetas com frases em caixa alta impressas em relevo dividem o espaço da página com inscrições em tipografia manuscrita e de máquina de escrever. A heterogeneidade da tipografia concretiza a intenção de fugir ao comportamento linear, previsível, obediente, enquadrado. "Ser Crunch é sair da rotina e sair da mesmice." e "Cruncher é o que é e não se deixa rotular!" são frases de efeito que buscam gerar identificação com o público-alvo: o jovem rebelde que não quer mais ser criança, que não quer mais ser conduzido pelos outros.

Ao pé da página, a síntese da mensagem, grafada em caixa alta branca sobre fundo vermelho: "Cruncher que é cruncher detona no café da manhã...". 
"Detonar", no vocabulário jovem, refere-se a fazer o melhor, não hesitar diante de um desafio, dar conta do recado, mandar bem, arrasar, fazer bonito, executar o que é esperado ou ir além. A frase carimba o comportamento incentivado e endossado pela marca. Forma-se assim um campo discursivo que opõe um modo de ser infantil, dependente, passivo e perdedor (disfórico) a uma atitude independente, ousada, criativa (eufórica).

Figura 26. Verso da embalagem de Nestlé Crunch.

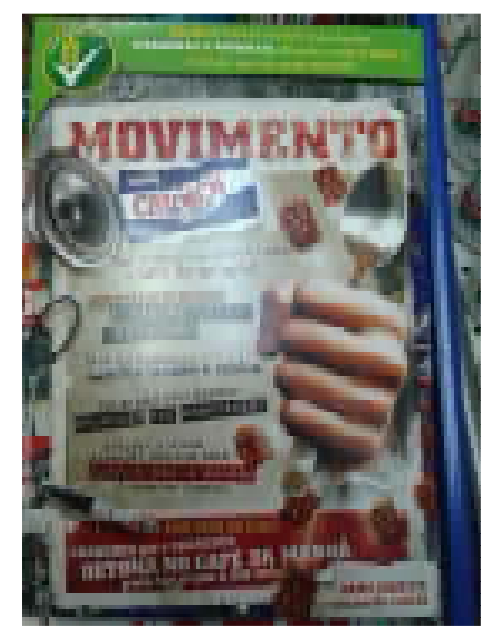

Imagem captada pela pesquisadora em dez 2012.

Como vimos anteriormente, o verbo "detonar" aparece também na face lateral esquerda da embalagem: "Comece seu dia detonando". Neste contexto, o sentido do verbo está concretamente associado a comer Crunch ${ }^{\circledR}$ com leite no café da manhã, conforme as nutricionistas sugerem. Comer Crunch ${ }^{\circledR}$ no café da manhã é mandar bem no contexto social desse público-alvo.

Podemos considerar que, se o discurso aspiracional da marca é aceito pelo público-alvo como modelo, se o jovem consumidor da marca se identifica com esse comportamento e assume para si o ethos da marca, segundo o movimento de significados descrito por MCCRACKEN (2003) e adaptado por LLANO LINARES \& TRINADE (2001), então um outro discurso que recomende "pegar leve", reduzir, moderar, suavizar, trocar por opções mais saudáveis, seguir outras recomendações ou obedecer dificilmente atrairá esse mesmo jovem. Se essa forma de comunicação funciona para esse público, então talvez uma estratégia de comunicação que 
pretenda fortalecer o discurso da saúde em embalagens voltadas para esse público deva também buscar o engajamento dos jovens "rebeldes" em direção a uma alimentação saudável explorando sua predisposição para a revolta. Se esse jovem deseja romper com alguma coisa que lhe parece errada, atrasada ou limitante, então talvez seja mais frutífero atrair sua atenção aproveitando essa sua motivação do que usando linguagens e conteúdos que não fazem sentido para ele.

\section{Adendo}

A embalagem de Crunch analisada neste capitulo foi fotografada em fins de 2012. Um ano depois, foi encontrada no mesmo supermercado uma embalagem diferente. Onde se lia "vitaminas e minerais", na face frontal, passou-se a ler "fonte de cálcio e ferro". A citação de estudos científicos foi substituída por um texto que ressalta o teor de cálcio do produto. A face posterior havia sido totalmente reformulada. Não havia mais a mão empunhando a colher, nem o mesmo texto. No lugar, havia fotos de jovens em situações de lazer e frases sobre quebrar a rotina no espírito crunch (Figura 27).

As mudanças não invalidam a presente análise. Ao contrário, confirmam que o discurso permanece o mesmo, ainda que o conteúdo e a linguagem tenham mudado.

Figura 27. A embalagem de Nestlé Crunch no fim de 2013.
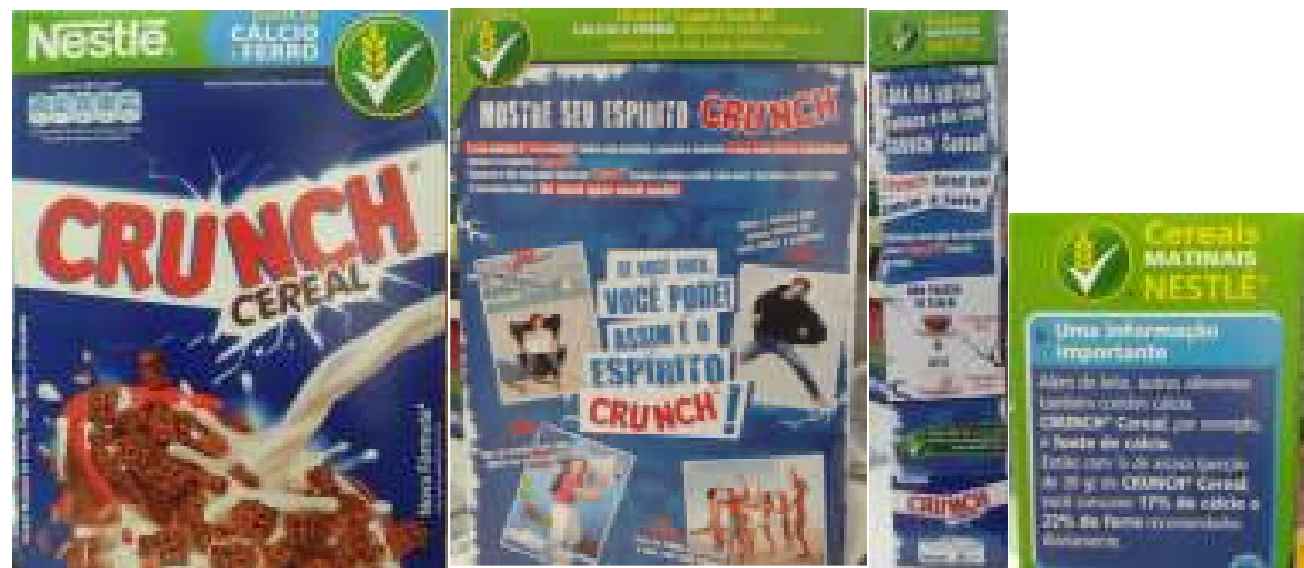

Imagens captadas pela pesquisadora. 


\section{EMBALAGEM 2 (ethos Especialista)}

A embalagem é um saco plástico leitoso e impresso em quatro cores, que normalmente fica deitado na prateleira. O produto não é visível através da embalagem, mas é possível sentir e ouvir sua crocância ao tocar a embalagem.

$\mathrm{Na}$ face frontal, a marca Superbom ${ }^{\circledR}$ e o nome do produto (Skarchitos ${ }^{\mathrm{TM}}$ ) saltam aos olhos (Figura 28). O nome "Skarchitos" não faz parte do vocabulário do brasileiro. Segundo informação fornecida por telefone em 18/12/2013 pelo Serviço de Atendimento ao Consumidor (SAC) da Produtos Alimentícios Superbom Indústria e Comércio, antiga detentora da marca Superbom, a fabricação do Superbom Skarchitos foi assumida pela Kellogg Brasil em 1997. Essa informação foi confirmada pelo SAC da Kellogg Brasil em 06/01/2014. Foi informado que nada mudou no produto nem na embalagem com a aquisição, mas um dos três produtos da linha foi descontinuado. A atendente informou também que a aquisição ocorreu porque a linha de cereais da Superbom era concorrente direta da Kellogg. Ainda assim, a logomarca Superbom continua estampando a embalagem do Skarchitos. A Kellogg Brasil aparece no verso da embalagem, como fabricante e responsável pelo SAC.

Figura 28. Face frontal da embalagem de Superbom Skarchitos.

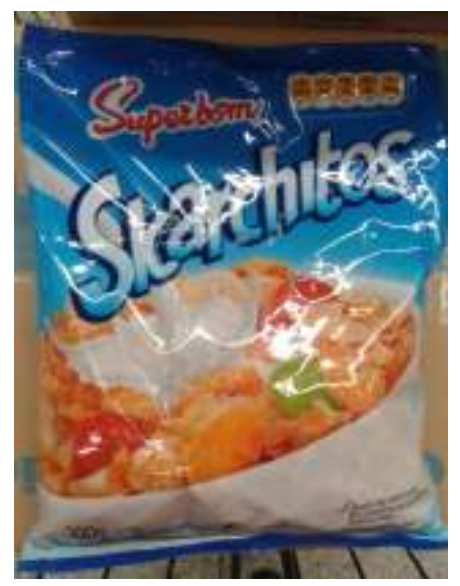

Imagem captada pela pesquisadora. 
Nesta embalagem, a marca Kellogg não é destacada. Não é ela quem assume a comunicação com o público-alvo, portanto, e sim a Superbom, que neste caso pode ser considerada uma marca virtual, uma marca-memória, uma vez que toda a comunicação da embalagem foi definida há vários anos por uma empresa que já não está no comando das operações. A imagem da marca transmitida ao consumidor é essa que um dia a Superbom criou. É com ela que o consumidor há de se relacionar em seu ritual de consumo.

Abaixo do nome do produto, sobre fundo azul, está a imagem de uma porção generosa de flocos de milho, com pedaços de morango, banana e uma fruta verde, embebida em leite dentro de uma tigela branca "sem fundo". No quadrante superior direito da face frontal está presente a pequena tabela com o excerto da tabela nutricional do verso, para porção de 30 gramas, com asterisco no lugar das necessidades diárias de açúcares e a frase "Valor diário para açúcares não estabelecido." inscrita verticalmente. No canto inferior direito da face frontal, a informação nutricional complementar "Fonte de vitaminas B2, niacina, ácido fólico, ferro e zinco" e a inscrição "contém 6 porções". No rodapé, a informação do peso líquido (200g) e a descrição “cereal matinal de milho com açúcar”, em caixa alta e fonte pequena sobre fundo branco.

Assim como a embalagem do Nestlé Crunch, a de Skarchitos apresenta a porção de 30 gramas e a informação nutricional conforme a legislação. Aqui também o termo "cereal" é empregado para designar mais a categoria de produto do que o grupo de alimentos ao qual o milho pertence. A inscrição "cereal matinal de milho" traz a ideia de que o cereal é um produto feito de milho, e não o próprio milho. O milho é, assim, colocado como ingrediente do produto.

$\mathrm{O}$ verso da embalagem é mais rico em informações. No quadrante superior esquerdo, a marca fantasia (Superbom) e o nome do produto se repetem. Logo abaixo, um chamado em negrito: "Tenha um estilo de vida saudável.” (Figura 29). A frase é reveladora do discurso da marca. O verbo "ter" conjugado no modo imperativo remete à regra máxima da sociedade de consumo: é preciso ter. Todos querem ter alguma coisa para alcançar determinado objetivo. Quem consome tem.

Para explicitar o potencial de geração de sentido do verbo, podemos facilmente substituir o objeto de desejo, mantendo o desejo de posse. 
Tenha um estilo de vida saudável.

Tenha um corpo magro.

Tenha comida fácil na mesa todo dia.

Tenha um multiprocessador de alimentos.

Tenha um carro melhor.

Tenha roupas da última moda.

Tenha um casaco para os dias frios.

Figura 29. Detalhes do verso da embalagem de Superbom Skarchitos.
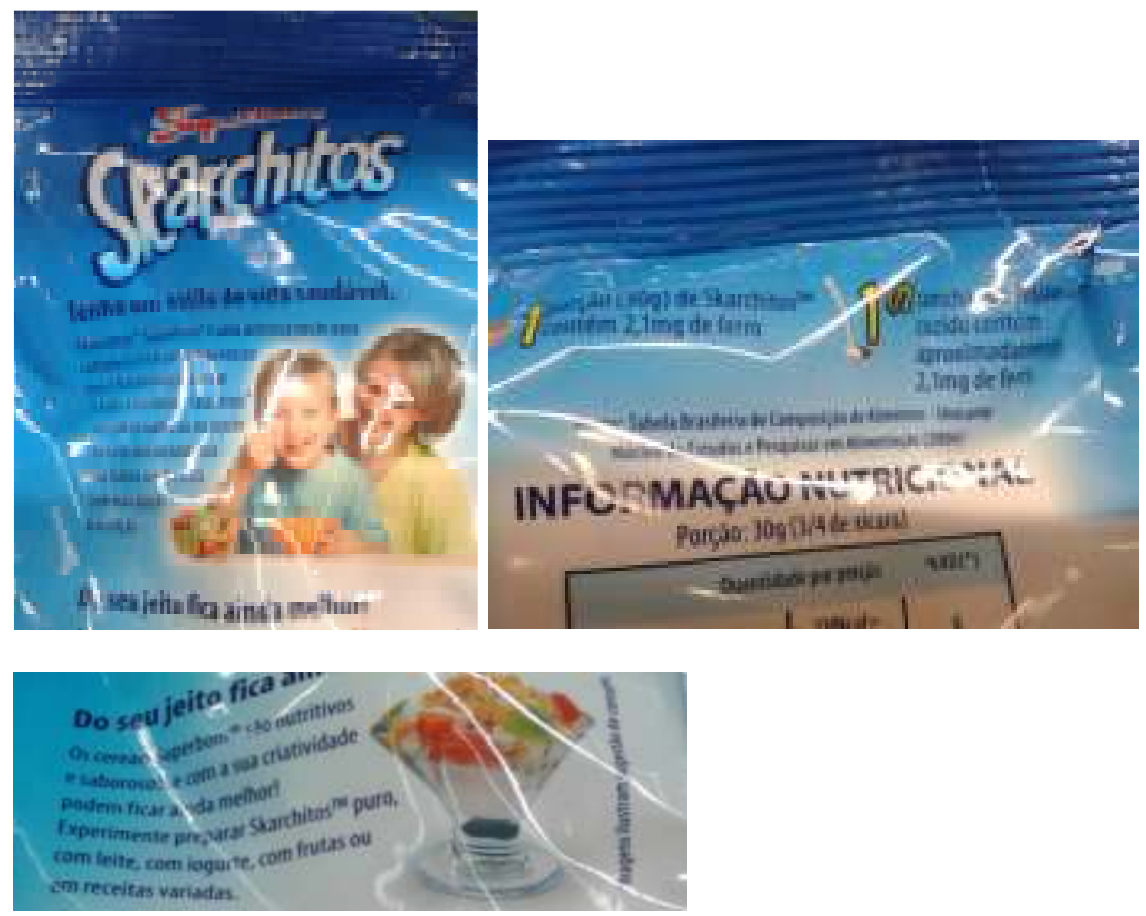

Imagens captadas pela pesquisadora.

Quem recomenda a posse de determinada coisa sabe o benefício que essa coisa pode proporcionar. A frase "Tenha um estilo de vida saudável" comunica que ter um estilo de vida saudável é o comportamento mais certo a adotar. E quem recomenda ter um estilo de vida saudável nessa embalagem é a marca. A marca coloca-se, portanto, no lugar de quem sabe o que é bom. Esse é o lugar do especialista. A marca assume, assim, um ethos de guia, orientador, possuidor do conhecimento sobre o caminho mais certo a seguir. 
Mas há, aqui também, no interdiscurso, a memória da mulher que antes da marca nos disse o que era bom. Logo abaixo da frase está a imagem de uma mulher branca e loira que sorri atrás de uma criança também branca e loira, do sexo masculino. A criança leva à boca uma colher e segura com a outra mão, sobre uma mesa, uma tigela cor de laranja quase transbordando de flocos de milho. Na frente da criança, sobre a mesa, também se vê uma segunda tigela, esta transparente, com rodelas de kiwi, pedaços de morango e mais flocos de milho dentro. Aqui, novamente, o tamanho das porções na imagem contrasta com a porção indicada na tabela nutricional. No percurso da leitura, essa é a imagem imediatamente associada à frase imperativa acima dela. A imagem de uma criança amparada por um adulto, que por sua vez, ao sorrir e aparentemente tocar a criança por trás, endossa o comportamento da criança.

Ao lado da imagem, o texto: "Skarchitos ${ }^{\mathrm{TM}}$ Superbom ${ }^{\circledR}$ é uma deliciosa opção para complementar uma alimentação rica e balanceada para você e toda a sua família. Skarchitos ${ }^{\mathrm{TM}}$ no café da manhã ou no lanche da tarde proporciona para sua família um dia a dia com mais sabor e nutrição."

Segundo MAINGUENEAU (2002), "todo discurso, por sua manifestação mesma, pretende convencer instituindo a cena de enunciação que o legitima" (p. 87). E a cenografia legitima um enunciado que, por sua vez, deve legitimá-la.

$\mathrm{Na}$ cenografia criada pela marca para a embalagem de Skarchitos, ter um estilo de vida saudável envolve café da manhã em família e cereal matinal com frutas todo dia. A imagem e o texto comunicam que o público-alvo desse produto é a família. A ideia é que adultos e crianças irão apreciar seu sabor e beneficiar-se da nutrição que ele oferece. A sugestão de consumo no café da manhã é verbalizada ("Skarchitos ${ }^{\mathrm{TM}}$ no café da manhã ou no lanche da tarde"). A menção ao dia a dia reforça a intenção da marca de convencer o público a consumir o produto diariamente, como desjejum. No conjunto, a mensagem sugere que o hábito de consumir Skarchitos todas as manhãs corresponde a um estilo de vida saudável.

Abaixo desse bloco de texto e imagem está um segundo bloco, destacado pela chamada, em negrito: "Do seu jeito fica ainda melhor!". A imagem é de uma taça de vidro com flocos de milhos, frutas e leite ou iogurte dentro. O texto ao lado da imagem diz: "Os cereais Superbom ${ }^{\circledR}$ são nutritivos e saborosos, e com a sua 
criatividade podem ficar ainda melhor! (sic) Experimente preparar Skarchitos ${ }^{\mathrm{TM}}$ puro, com leite, com iogurte, com frutas ou em receitas variadas.” (Figura 29).

Esse segundo texto repete a valorização do sabor e da nutrição que o produto oferece e verbaliza a sugestão de consumo que já estava presente nas imagens descritas anteriormente. Podemos inferir que os acompanhamentos sugeridos (frutas, leite, iogurte) justificam o uso do verbo "complementar" no texto do primeiro bloco. O leitor pode entender que Skarchitos sozinho não é um café da manhã balanceado, mas o será se acompanhado desses outros alimentos.

Quanto ao tom do texto, podemos observar que o uso do ponto de exclamação ao final das frases transmite entusiasmo. O texto do segundo bloco tem um efeito motivacional: procura valorizar uma capacidade que o coenunciador supostamente possui (criatividade) e incentivá-lo a acrescentar complementos variados e coloridos aos flocos de milho. E a imagem contribui para esse efeito. Além do colorido das frutas, a taça de vidro, comumente usada em sorveterias e restaurantes para servir "sundae", remete a momentos de lazer e indulgência.

A metade direita da face posterior da embalagem está reservada à informação nutricional. Como já dito, a informação nutricional complementar na face frontal da embalagem diz que o produto é fonte de vitaminas e minerais. No canto superior direito da face posterior da embalagem, há uma comparação entre o teor de ferro numa porção de Skarchitos e numa concha e meia de feijão cozido: "1 porção (30g) de Skarchitos ${ }^{\mathrm{TM}}$ contém $2,1 \mathrm{mg}$ de ferro. $1 / 2$ concha de feijão cozido contém aproximadamente 2,1mg de ferro" (Figura 29). A tabela nutricional, por sua vez, informa que uma porção de Skarchitos contém 15\% das necessidades diárias de ferro de um adulto.

A comparação entre os teores de ferro de Skarchitos e do feijão - leguminosa à qual culturalmente se atribui um alto teor de ferro e que faz parte do almoço diário do brasileiro - faz parecer que os dois alimentos são equivalentes. A comparação pode levar o consumidor a entender que tanto faz comer uma concha de feijão todo dia no almoço ou uma xícara de flocos de milho todo dia no café da manhã, já que o teor de ferro é o mesmo. Ou que, se comeu Skarchitos de manhã, não precisa comer feijão no almoço. Para a criança que se recusa a comer o almoço servido e prefere as guloseimas, esse é o discurso perfeito. 
É um discurso que incorpora parcialmente um conhecimento científico e cria um mito bastante conveniente ao mercado de "cereais matinais", mas traiçoeiro para a saúde pública. Ele assume que a nutrição se resume à presença de nutrientes nos alimentos, deixando de lado todas as outras substâncias presentes nos alimentos e seu complexo mecanismo de aproveitamento pelo organismo. Ele iguala a nutrição oferecida por um produto industrialmente processado e enriquecido à de um alimento integral preparado numa cozinha. É um discurso carregado ideologicamente, a serviço do mercado. Novamente a ideologia do nutricionismo, disfarçada de conhecimento científico, traveste o discurso publicitário e permite que os consumidores façam escolhas alimentares baseadas em mitos.

A partir dessa estratégia de comunicação, o consumidor não é levado a entender que Skarchitos é um produto enriquecido e que o alardeado ferro presente no produto foi artificialmente adicionado, diferentemente do ferro do feijão. Essa informação jamais é destacada. É apresentada discretamente, na lista de ingredientes.

A lista de ingredientes informa que Skarchitos é composto de milho, açúcar, sal e micronutrientes adicionados, incluindo ferro reduzido. Somente na leitura atenta e qualificada da lista de ingredientes é que se esclarece que tais vitaminas não são naturais do milho em flocos, mas foram adicionadas ao produto no processamento. $\mathrm{O}$ esclarecimento de que o processamento do milho leva a perda de nutrientes e que o enriquecimento com vitaminas sintéticas procura compensar essa perda está ausente.

Assim, no discurso da marca, alimentação saudável consiste na repetição diária do ato de consumo de alimentos com nutrientes. A marca comunica que é preciso adotar um hábito para o que considera alimento principal, ainda que haja oportunidade para variar a experiência de consumo com ingredientes adicionais diferentes de um dia para o outro. De preferência, um hábito único para toda a família, de modo que um incentive o outro a continuar repetindo o mesmo comportamento geração após geração. 


\section{EMBALAGEM 3 (ethos Especialista)}

A embalagem analisada é uma caixa de papelão com 200 gramas de produto (Figura 30). O nome do produto, "Corn Flakes", está inscrito em caixa alta e fonte preta avolumada sobre fundo branco, ocupando boa parte da metade superior da face frontal da caixa, o que lhe dá grande destaque. Abaixo, há uma ilustração: um galo verde sorridente de crina vermelha, bico amarelo, lenço vermelho no pescoço e uma "sobrancelha" erguida segura com a "mão" esquerda uma espiga de milho e, com o dedo indicador da "mão" direita, aponta para a espiga, como quem recomenda algo que vale a pena. O galo é uma mascote da marca chamada Comelius, segundo inscrição minúscula perto do dedo indicador. Da espiga de milho saem dois flocos de milho, e a frase "Diretamente do milho!" reforça o significado da figura. Todas as frases nessa embalagem estão traduzidas para o espanhol.

Figura 30. Kellogg's Corn Flakes, faces frontal e lateral.

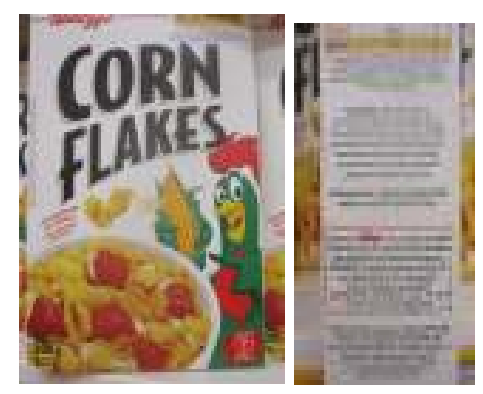

Imagens captadas pela pesquisadora.
Figura 31. Kellogg's Corn Flakes, verso.

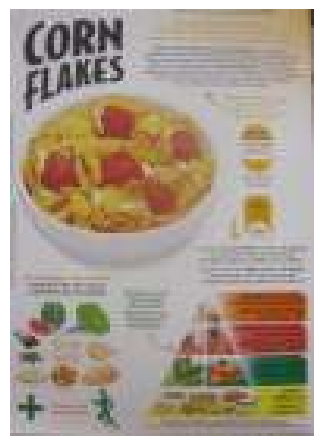

Imagem captada pela pesquisadora.

As mascotes, como o galo dessa embalagem, simbolizam a marca e fazem parte de seu sistema de comunicação, “desempenhando um papel mediador entre a realidade física da marca e a realidade psíquica e emocional dos diferentes 
públicos" e favorecendo a conexão afetiva entre eles (PEREZ, 2011, p. 61). Neste caso, a conexão com a marca Corn Flakes da Kellogg. Geralmente as mascotes são animadas, têm vida. Citando um trabalho do Observatório da Publicidade de Portugal, PEREZ (2011) diz que as mascotes "representam o significado da marca adaptado ao desenvolvimento cognitivo e psicológico da criança".

$\mathrm{Na}$ metade inferior da face frontal, uma tigela de flocos de milho com morangos e leite está bem próxima do olhar, de modo que parte da tigela não aparece. Uma frase inscrita na vertical em fonte minúscula avisa que a imagem do produto foi ampliada "para mostrar textura". No quadrante inferior direito, um módulo vermelho (sobre fundo verde escuro, cor oposta ao vermelho, o que lhe dá destaque) avisa com inscrição ilustrada em fonte branca: "Rende aprox. 7 porções". O peso líquido total, 200 gramas, é informado sem destaque no quadrante inferior esquerdo, logo acima da descrição do produto: "flocos de milho".

A descrição do produto nesse local omite o fato de ele conter açúcar, malte, sal e micronutrientes adicionados, informação que aparece na lista de ingredientes. O destaque ao milho por meio dos textos e da mascote - uma ave que, nos modos tradicionais de avicultura, se alimenta de milho - funciona como uma equação lógica que iguala o produto adoçado, salgado e enriquecido à base de flocos de milho ao milho tal qual ele vem da terra. Ocorre, assim, um apagamento da transformação sofrida pelo milho no processo industrial.

Corn Flakes são flocos de milho.

Os flocos de milho vêm diretamente do milho.

O milho é um cereal.

O galo come milho.

Criança come milho.

Criança come o mesmo que o galo.

A marca Kellogg's aparece em vermelho no topo da face frontal. A informação sobre a marca registrada nos Estados Unidos, numa das faces laterais, indica que é uma marca multinacional (Figura 30).

Curiosamente, nessa embalagem não há destaque para o conteúdo de vitaminas e sais minerais. Estes só aparecem na tabela nutricional e na lista de ingredientes. 
Próximo à tabela nutricional, numa das faces laterais, está um selo BKA Kosher Parve, que atesta que o produto é fabricado conforme os preceitos alimentares judaicos. ${ }^{\mathrm{g}}$

A face posterior da caixa traz novamente o nome do produto e a imagem, desta vez inteira, da tigela (Figura 31). No quadrante superior direito está a informação nutricional complementar do tipo VDR, baseada na porção de 30 gramas. Logo abaixo, as frases: "Comprometimento em transmitir a informação adequada para você e sua família!" e "Agora nas embalagens dos Cereais Kellogg's ${ }^{\circledR}$, você encontra informações sobre a quantidade de nutrientes que 1 porção do cereal fornece em relação à necessidade diária de $2.000 \mathrm{kcal}$ ou $8.00 \mathrm{~kJ}$ ”. E então segue uma explicação de como o VDR deve ser lido.

$\mathrm{Na}$ metade inferior da face posterior está uma manifestação explícita do discurso da marca em relação às escolhas alimentares mais saudáveis. O texto "Não se esqueça! A fórmula de uma vida saudável: Alimentação balanceada + atividade física" é acompanhado de uma ilustração que representa melancia, alface, peixe, ervilhas, chocolate, manteiga, queijo, pão e uma tigela de flocos de milho com morangos e leite idêntica à da imagem maior. Uma seta em curva saindo da frase "Mantenha uma alimentação balanceada!" direciona a leitura para uma pirâmide alimentar dividida em quatro patamares.

O patamar de base da pirâmide, de fundo amarelo, é identificado por uma "etiqueta" que diz: "cereais e tubérculos" e contém alimentos como pão de forma, macarrão e batata, entre outros menos fáceis de reconhecer devido à qualidade do desenho, incluindo uma tigela branca com conteúdo amarelo e vermelho. O patamar logo acima tem fundo verde escuro, contém folhas verdes, tomate, pepino, pimenta, mamão, laranja, maçã, banana, e é identificado por "verduras e frutas". O terceiro patamar, de fundo avermelhado, é o das "leguminosas e alimentos de origem animal", e contém frango, peixe, leite, queijo, feijões e amendoim. A ponta da pirâmide corresponde a "gordura, óleos, doces, chocolates e salgadinhos", e contém manteiga, uma lata que pode ser de refrigerante, sorvete e chocolate. Abaixo da pirâmide, a indicação do site da marca, que contém mais informações.

\footnotetext{
${ }^{\mathrm{g}} \mathrm{http}: / /$ www.bka.com.br/simbolos.html
} 
Vejamos, novamente, como o deslizamento de sentidos funciona nessa formação discursiva.

Corn Flakes $=$ milho

Milho $=$ cereal

Corn Flakes $=$ cereal

Cereais estão na base da pirâmide alimentar.

Corn Flakes estão na base da pirâmide alimentar.

O termo "alimentação balanceada" aparece duas vezes. Numa, associada a uma combinação de todos os grupos alimentares, sem distinção. Na outra, remete à distribuição dos alimentos na pirâmide. Como sabemos, a pirâmide é uma representação gráfica de um conjunto de recomendações alimentares estabelecidas pelos órgãos oficiais de saúde, cuja origem está na política alimentar dos Estados Unidos nos anos 1980. O interdiscurso constituinte da formação discursiva nessa embalagem deriva, portanto, das negociações ocorridas entre o governo e a indústrias americanas há 30 anos (NESTLE, 2003).

A primeira pirâmide alimentar foi elaborada pelo Serviço de Informação para a Nutrição Humana (HNIS) do Departamento de Agricultura (USDA), alguns anos depois de um modelo anterior, circular, o Food Wheel, ser reprovado pela indústria Na segunda tentativa, o órgão pretendia desenvolver uma ilustração atraente que ajudasse as pessoas a se lembrar das mensagens mais importantes: variedade (múltiplos grupos de alimentos), proporcionalidade (número apropriado de porções) e moderação (restrições a gordura e açúcar) (NESTLE, 2003, p. 54). Foi eleita a pirâmide, quase lançada em 1991. Mas o desenho ofendeu os produtores de carne, já que a pirâmide recomendava comer menores quantidades desse alimento, e sob pressão da indústria teve de ser reformulado. Produtores de carnes e laticínios não gostaram da ideia de hierarquia transmitida pela pirâmide e sugeriram uma ilustração com o formato de uma tigela, que denotaria maior equivalência entre os grupos de alimentos (p. 62). Em 1992, o USDA lançava o Food Guide Pyramid, e logo o símbolo seria adotado por escolas e embalagens de alimentos e se tornaria o dispositivo de educação nutricional mais largamente distribuído e mais facilmente reconhecido do país (p. 63-6).

A pirâmide americana de 1992 foi adaptada para a população brasileira em 1999 pela equipe de Sonia Tucunduva Philippi, professora da Faculdade de Saúde 
Pública da USP, segundo a qual os guias alimentares devem: promover e manter a saúde global do indivíduo, ser baseados em pesquisas atualizadas, ter uma visão global da dieta, ser úteis para o público-alvo, encontrar uma forma realista de suprir as necessidades nutricionais com base na dieta habitual de cada população, ser práticos e dinâmicos, permitindo o máximo de flexibilidade para a escolha dos alimentos (PHILIPPI et al, 1999). Nessa adaptação, os alimentos foram distribuídos em oito grupos: 1) pães, cereais, raízes e tubérculos (pães, farinhas, massas, bolos, biscoitos, cereais matinais, arroz, feculentos e tubérculos: 5 porções no mínimo a 9 no máximo); 2) hortaliças (todas as verduras e legumes, com exceção das citadas no grupo anterior: 4 porções no mínimo, 5 no máximo); 3) frutas (cítricas e não cítricas: 3 porções no mínimo, 5 no máximo); 4) carnes (carne bovina e suína, aves, peixes, ovos, miúdos e vísceras: 1 porção no mínimo, 2 no máximo); 5) leite (leites, queijos e iogurtes: 3 porções); 6) leguminosas (feijão, soja, ervilha, grão de bico, fava, amendoim: 1 porção); 7) óleos e gorduras (margarina/manteiga, óleo: 1 porção no mínimo, 2 no máximo); 8) açúcares e doces (doces, mel e açúcares: 1 porção no mínimo, 2 no máximo).

Considerado o raciocínio lógico que dá origem à formação discursiva na embalagem do Kellogg's Corn Flakes, legitimado pela pirâmide alimentar e seu caráter de símbolo reconhecido como guia alimentar confiável, o sentido gerado pelo conjunto das mensagens é que o produto cereal matinal à base de flocos de milho faz parte do grupo de alimentos que devem ser consumidos em maior quantidade numa alimentação balanceada.

Ao incorporar à mensagem publicitária o discurso da ciência da nutrição, a Kellogg coloca-se no papel daquele que faz recomendações nutricionais e assume o ethos do especialista em saúde. Na comunicação que estabelece com seu públicoalvo, busca legitimar seu papel de orientador dos hábitos alimentares, incutindo o valor da marca nas práticas cotidianas e até no vocabulário, uma vez que por sua mediação o termo "cereal” torna-se sinônimo de café da manhã saudável pronto para o consumo. 


\section{EMBALAGEM 4 (ethos Aliado)}

A "granola caseira tradicional" da Mãe Terra é comercializada em sacos plásticos parcialmente transparentes e impressos em quatro cores, em mais de um tamanho, que normalmente ficam deitados na prateleira, tanto em supermercados quanto em lojas de produtos ditos naturais, como a rede Mundo Verde. Para esta análise, foi considerada a embalagem de dimensões $20 \mathrm{~cm}$ x 13,5 cm.

A transparência do plástico na embalagem da granola Mãe Terra é um diferencial relevante em relação às embalagens analisadas anteriormente, pois permite que o consumidor veja o produto antes da compra, eliminando a barreira visual que as caixas de papelão e os plásticos inteiramente leitosos impõem. Com isso, o consumidor pode ter uma noção realista do tamanho dos pedaços de frutas e oleaginosas presentes, da integridade dos grãos e da quantidade de ingredientes na granola. Em vez de confiar numa ilustração hiperbólica que apenas sugere qual a aparência do produto, o consumidor pode confiar em seus próprios olhos e decidir se compra o produto ou não com base em informação comprovada e concreta (Figura 32).

Mas a Mãe Terra não entrega apenas transparência em sua embalagem. A comunicação de marketing da marca está abundantemente presente, ocupando a maior parte do saco plástico.

Figura 32. Granola Caseira Mãe Terra, frente e verso.

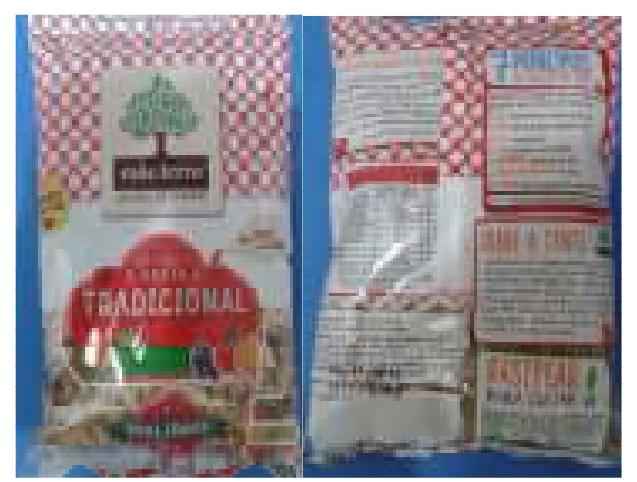

Imagens captadas pela pesquisadora. 
A face frontal da embalagem exibe dois grandes elementos visuais de cor vermelha que disputam a atenção: a estampa quadriculada na metade superior e o módulo em que se lê "tradicional". O quadriculado vermelho seguido de uma faixa branca com borda bordada lembra uma toalha de mesa de cozinha doméstica. $\mathrm{O}$ módulo vermelho em que se lê o nome do produto e o termo "tradicional", grafado em caixa alta e fonte sombreada, é contornado por um pesponto e ilustrado com um tema rural e bucólico.

O termo "tradicional" aparece na embalagem de diversos produtos comestíveis, comumente para identificar a versão mais antiga do produto, quando com o tempo ele deu origem a variações na composição ou no sabor. $\mathrm{Na}$ embalagem de outras "granolas caseiras" da Mãe Terra, o termo "tradicional" nessa mesma parte da embalagem é substituído por "tradicional light", "frutas \& mel”, "maçã \& canela" e "banana \& cacau". O termo "tradicional" nesse contexto pode ser interpretado, assim, meramente como o nome do sabor da granola. Ou pode remeter a costumes antigos que valha a pena preservar ou resgatar. Esse efeito de sentido mais simbólico é reforçado por outros elementos que transmitem essa mensagem, em todas as embalagens da marca.

Nessa embalagem, a logomarca da Mãe Terra está localizada no centro de um quadrado cujo contorno lembra um alinhavo, o que faz com que o quadrado lembre um retalho de tecido que foi costurado de forma rústica num ambiente caseiro. A ilustração mostra uma casa simples, dessas que as crianças desenham, no meio de um grande campo verde, com árvore frutífera no quintal, borboleta, passarinho cantando. Esse não é um ambiente caseiro qualquer. A costura, a toalha quadriculada e a ilustração bucólica trazem a memória da casa de alguém que mora no campo, que costura e borda. Talvez a casa da avó, talvez da mãe. Uma mulher "prendada", que faz artesanato, tem uma coleção de receitas maravilhosas, cozinha como ninguém e deixa a casa sempre com cheirinho de bolo recém-saído do forno. Aquela de quem todo mundo tem saudade.

Não é preciso que a avó/ mãe apareça ou seja mencionada explicitamente. A memória dela está presente nesse plano de expressão, por meio dessa metonímia figurativa. E, na presença dessa memória, dessa personagem idealizada que faz parte de uma memória cultural coletiva, o termo "tradicional" tem o sentido desse 
ambiente caseiro, aconchegante, de que se tem saudade porque talvez esteja no passado. Um passado em que a comida era colhida no quintal e preparada em casa por alguém em quem a gente confiava, alguém que a gente amava e que só fazia coisas boas.

Nesse discurso, a granola é tão caseira, natural e artesanal quanto a costura e a comida da vovó/ mamãe querida.

Outro sentido para o termo "tradicional" aparece também no selo que atesta a qualidade da marca desde 1979, no "rodapé" da face frontal. Destacar a idade da marca também é um recurso comum na publicidade, pois o acúmulo de anos, além de denotar acúmulo de experiência, sugere que se trata de gente conhecida, e que portanto merece confiança.

Portanto não é só a granola que é confiável. A Mãe Terra quer trazer para a própria marca esses mesmos valores, esse mesmo ethos.

A marca "mãe terra" está grafada em caixa baixa sobre o desenho de uma árvore de tronco robusto e folhas verdes, no local que corresponde à terra e à raiz. O slogan é: “natural de verdade". Se a árvore simboliza a natureza, a marca Mãe Terra está na raiz dessa natureza, fornecendo o alimento de que ela precisa. Trata-se de uma simbologia muito forte para uma marca de alimentos. Por meio dessa logomarca, a Mãe Terra se coloca simbolicamente no lugar da natureza, a "mãenatureza", aquela que dá origem ao alimento mais puro e que no mundo pósmoderno já não é tão fácil de encontrar.

No canto inferior direito da face frontal da embalagem estão claims como "sem aditivos artificiais" e "5 grãos integrais". Mais acima, o passarinho canta “com mel e castanhas". As alegações buscam avisar ao consumidor que, diferentemente dos outros, esse produto não tem aditivos artificiais, portanto indesejáveis, e contém ingredientes naturais, portanto desejáveis, como grãos integrais, mel e castanhas. É uma forma de valorizar os ingredientes do produto como atributo importante na escolha do consumidor, diferentemente das marcas que buscam valorizar os nutrientes.

O sentido atribuído ao termo "cereal" aqui também difere do encontrado em embalagens de outras marcas. A descrição do produto, localizada no topo da face frontal da embalagem, diz "Mistura de flocos de cereais integrais com castanhas e 
frutas". O produto não é descrito como sendo um cereal, mas sim uma mistura de cereais minimamente processados com outros ingredientes, o que de fato ele é.

No verso da embalagem, que mantém a toalha de mesa quadriculada como fundo, há uma reivindicação, em caixa alta: “queremos granola de verdade!”. Logo abaixo, um texto que explicita que verdade seria essa: "Crocante, deliciosa e sem ingredientes artificiais com nomes esquisitos. Aveia integral, castanhas, linhaça dourada, mel, frutas secas e o jeito Mãe Terra de fazer. Essa é a Granola Caseira Tradicional. Levou anos, mas conseguimos desenvolver nossa fórmula especial!” (Figura 32).

Assim, a Mãe Terra comunica que granola de verdade é aquela que é feita de ingredientes nobres, não tem ingredientes artificiais com nomes esquisitos e resulta de anos de experiências na cozinha. Nesse discurso, o jeito Mãe Terra de fazer só pode ser o jeito caseiro, aquele da avó/ mãe, que a gente já conhece e confia.

A "verdade" oferecida pela Mãe Terra desde o slogan é defendida mais uma vez num quadro posicionado no quadrante superior direito da face posterior da embalagem, encabeçado pelo título “7 princípios dos produtos Mãe Terra” (em caixa alta). O título por si só já posiciona mais um diferencial, pois não é comum que as marcas de alimentos comuniquem ter princípios por meio de suas embalagens. Com isso, a Mãe Terra transmite a ideia de que é uma empresa diferente por atuar no mercado segundo determinados valores, que ela julga serem importantes para seu público-alvo. E assume publicamente o compromisso de somente agir segundo esses valores, o que pode ser interpretado como um pacto de confiança com o consumidor.

Dentro do quadro, a frase "Não basta ser integral e ficar no blá blá blá, queremos ser natural de verdade (sic)" é seguida de sete quesitos estipulados pela marca para caracterizar o que seria esse "natural de verdade", inscrito em verde para ressaltar o valor da natureza:

1. Sem conservantes e aromas artificiais

2. Sem açúcar branco e gordura trans

3. Sem transgênicos

4. Mais integral, mais nutritivo

5. Orgânico, sempre que possível

6. Níveis moderados de sódio

7. Sabor! Além de natural, tem que ser gostoso! 
O leitor apressado poderá entender que o produto não contém conservantes nem aromas nem açúcar adicionado. Mas a Mãe Terra não é assim tão radical. Natural de verdade, para a Mãe Terra, não significa absolutamente sem aditivos, mas sem aditivos chamados de artificiais, estes sim colocados pela marca no lugar de vilões a serem evitados. Aditivos chamados de naturais, como o aroma natural de baunilha e o aroma natural de coco, presentes na lista de ingredientes, são utilizados e incorporados no conceito de natural adotado pela marca. Natural de verdade também não significa sem açúcar, mas sem açúcar branco. O açúcar mascavo e o demerara são bem-vindos.

Além de expor seu conceito de natural e os valores que julga serem os valores de seu público-alvo, com esses sete princípios a Mãe Terra aponta quem são os inimigos que sua tribo - ela e seus consumidores - devem evitar e combater. Aditivos artificiais, açúcar refinado, transgênicos, alimentos refinados e cheios de sódio. Ela promove, assim, um conceito de alimentação saudável que exclui grande parte dos produtos à venda nos supermercados. E incentiva que seu público-alvo compare os produtos à venda segundo esses critérios.

Abaixo do quadro dos sete princípios vem outro quadro, intitulado "Sobre a gente", que fala mais diretamente quem é a Mãe Terra, o quem ela quer ser: "Trabalhamos com alegria porque acreditamos nos nossos alimentos. Em um mundo repleto de artificiais e refinados, dá orgulho oferecer produtos naturais deliciosos, que fazem bem para as pessoas e o planeta. Sempre foi assim, desde 1979. Visite-nos em maeterra.com.br, conheça nossa filosofia e veja dicas de saúde e receitas incríveis."

O uso da primeira pessoa em diversos momentos ("queremos", "trabalhamos", "nossa filosofia") posiciona a marca como parte do grupo de cidadãos que buscam uma alimentação mais cuidada, natural e seletiva, em oposição a um mercado de alimentos artificializado, enganoso, modernizado demais, que não faz bem para as pessoas nem para o planeta. Ao referir-se a si mesma como "a gente", ela se aproxima, informaliza, simplifica sua imagem. Quando se refere aos aditivos artificiais como "nomes esquisitos", ela cria empatia com o consumidor comum que não conhece os termos técnicos e desconhece os modos de produção alimentar industrial. Essa comunicação tem o efeito de chamar 
o público a unir-se à marca no mesmo nível de interesse, no mesmo conhecimento, no mesmo movimento. O movimento pelo consumo-cidadão.

Essa oposição que a marca toma como seu diferencial está na base de todo o discurso dessa embalagem. Elas podem ser explicitadas por meio de substituições linguísticas:

Queremos granola de verdade!

Não queremos granola de mentira!

Não queremos granola com conservantes e aromas artificiais!

Não queremos granola com açúcar branco e gordura trans!

Não queremos granola com transgênicos!

Não queremos granola pouco integral!

Não queremos granola nunca orgânica!

Não queremos granola com muito sódio!

Não queremos granola que não seja gostosa!

Granola com conservantes e aromas artificiais, açúcar branco, gordura trans, transgênicos e muito sódio não são de verdade; são de mentira; são enganosas.

Dá orgulho oferecer produtos que fazem bem para as pessoas e o planeta.

Dá orgulho oferecer granola de verdade.

Granola de verdade faz bem para as pessoas e o planeta.

Dá vergonha oferecer produtos que fazem mal para as pessoas e o planeta.

Granolas de mentira fazem mal para as pessoas e o planeta.

Queremos fazer bem para as pessoas e o planeta.

Não queremos fazer mal para as pessoas e o planeta.

Granola caseira faz bem para as pessoas e o planeta.

Granola industrializada não faz bem para as pessoas e o planeta.

Granola Mãe Terra faz bem para as pessoas e o planeta.

Mãe Terra faz bem para as pessoas e o planeta.

Quem consome granola Mãe Terra faz bem para as pessoas e o planeta.

Aqui podemos perceber que a intenção de comparar o produto Mãe Terra com a concorrência por esses critérios não diferencia apenas o produto ou a marca, mas também o consumidor. Conforme LLANO LINARES \& TRINDADE (2011) e LIMA \& MIKLASEVICIUS (2012), o movimento de significados por meio de rituais de consumo descrito por MCCRACKEN (2003) permite que o consumidor da marca sinta-se igualmente responsável pelo bem das pessoas (incluindo si mesmo) e do planeta ao dar preferência a produtos que fazem bem para as pessoas e o planeta.

O ethos da Mãe Terra é o de uma aliado desse consumidor que quer fazer melhor, que quer a comida natural de antigamente. A marca se coloca como um 
igual, uma parceira de idealismo e busca pelo bem. O que ela considera bom para a saúde não vem embalado num discurso de especialista, de um ente superior que detém um conhecimento científico ao qual o cidadão comum não tem acesso e por isso tem autoridade para ditar comportamentos. $\mathrm{O}$ conhecimento que ela toma como referência é o popular, o transmitido de geração em geração. É cultura.

E, desse lugar comum, rasteiro, popular, a marca se permite falhar. No quadro intitulado "Rastrear para cuidar", ela diz: "Sabemos que não somos perfeitos, mas nos esforçamos para fazer nossa parte.” E esse esforço é coletivo, comunitário. Ela novamente chama o público a participar de sua proposta: "Rastreie os 7 impactos ambientais e conheça a origem dos nossos produtos: maeterra.com.br/pensandobem".

Apesar do imperativo dos verbos ("rastreie", "conheça"), trata-se de mais de um convite do que de uma instrução. Um convite para conhecer, saber mais, valorizar o esforço da empresa em cuidar do planeta, participar mais.

Se o consumidor aceitar o convite e tiver interesse suficiente para entrar no site e ler sobre o programa, saberá que a Mãe Terra (diz que) procura fazer o bem para o planeta não só produzindo alimentos naturais, sem transgênicos, mas rastreando impactos ambientais que sua produção poderia causar. Saberá que o ícone verde em forma de ponto de exclamação feito de folha e planeta, avisando que esse cuidado é importante e talvez urgente, é a logomarca do projeto "Pensando Bem”. Saberá quais são os sete impactos ambientais rastreados, representados na embalagem também por ícones (Figura 33), e que o projeto contempla 38\% dos produtos da marca. E, sabendo disso, poderá talvez tomar novas decisões a respeito de seus padrões de consumo.

Ao dizer que se esforça para fazer sua parte, a marca ao mesmo tempo assume que tem uma responsabilidade e avisa que essa responsabilidade não é só dela. Há outras partes a serem cumpridas. A embalagem não aponta diretamente de quem seria a responsabilidade sobre essas outras partes ou quem também deveria fazer sua parte, mas por meio dos convites ela chama o consumidor a sentir-se corresponsável. Esses convites funcionam como um argumento. Eles comunicam que fazer questão de consumir somente alimentos feitos com os cuidados tomados pela marca e evitar os "vilões" é uma forma de o consumidor fazer sua parte. No 
discurso da Mãe Terra, fazer parte dessa tribo que se esforça para cuidar das pessoas e do meio ambiente - a tribo dos consumidores-cidadãos - já é fazer sua parte.

O campo discursivo formado nessa embalagem opõe o engajamento por uma alimentação mais saudável e sustentável à aceitação do modelo industrial predominante. Se o comportamento eufórico, incentivado pela marca, é o engajamento, então o disfórico seria a apatia, o conformismo, o consumo passivo de marcas que não fazem questão de fazer bem para as pessoas e o planeta. Os consumidores apáticos, desinteressados dessas questões, não são, portanto, o público-alvo da marca.

A embalagem traz ainda símbolos universais (usados em embalagens de outras marcas de alimentos e de produtos não alimentícios) para avisar que o plástico que contém a granola é reciclável e convidar o consumidor a descartá-lo numa lixeira seletiva (Figura 34). Esses símbolos estão posicionados na borda inferior do saco, entre o código de barras e o endereço da empresa, que em relação ao restante da embalagem apresenta desvantagem para a leitura. A borda é frisada e dobra facilmente, escondendo as mensagens impressas nela. Podemos inferir que o endereço da empresa, o telefone do $\mathrm{SAC}$ e os símbolos referentes à reciclagem são as informações que a marca julgou serem as menos importantes dessa embalagem.

Figura 33. Os 7 impactos ambientais rastreados pela Mãe Terra.

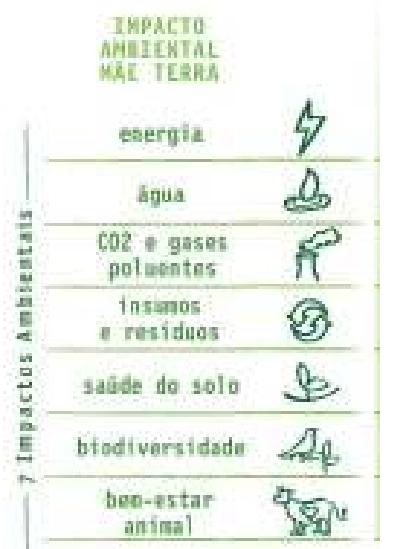

Disponível em: http://bit.ly/119ggGV
Figura 34. Símbolos que convidam a reciclar a embalagem.

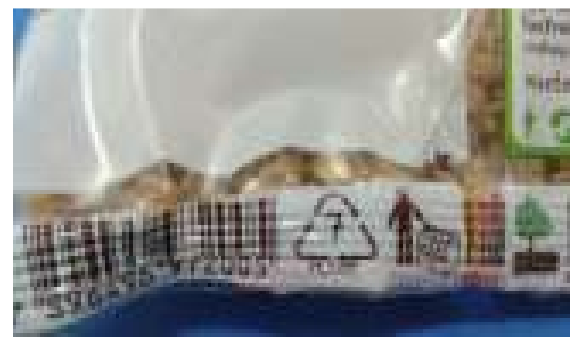

Imagem captada pela pesquisadora. 


\section{EMBALAGEM 5 (ethos Anfitrião festivo)}

O Cereal Açucarado Dia é um produto da marca própria da rede espanhola de supermercados Dia. Ele é vendido em duas embalagens: uma caixa de papelão com 300 gramas e um saco plástico opaco com 30 gramas. Em ambas a cor de fundo é o azul-escuro.

No centro das faces frontal e posterior da caixa, que são quase iguais, há uma personagem de feições meigas que indica que o produto é destinado ao público infantil. Trata-se de um floco de milho animado, que calça chinelos e surfa num outro floco de milho, este não animado, que lhe serve de prancha, sobre um splash branco que provavelmente representa o leite. Ao redor do floco animado, diversos flocos menores flutuam, como se espirrassem com a força da "onda" de leite (Figura 35).

Figura 35. Dia Cereal Açucarado, frente e detalhe do verso.

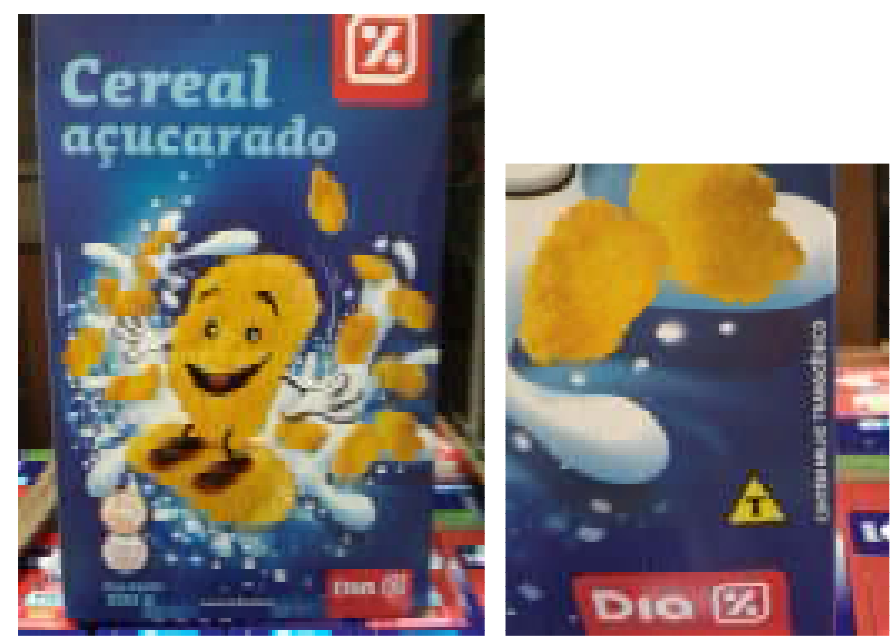

Imagens captadas pela pesquisadora.

No topo da mesma face está o nome do produto, grafado em azul, em fonte arredondada. Nos quadrante superior e inferior direitos está a logomarca Dia. No quadrante inferior esquerdo está a informação nutricional complementar, abreviada: "8 vit e 2 min - vitaminas e minerais" e "zero gordura trans". A abreviação parece 
ter sido usada para que os claims coubessem dentro dos círculos. Logo abaixo, o peso líquido. Ao lado, a inscrição "Indústria Brasileira".

A presença do açúcar no nome do produto explicita a intenção de atrair o público pelo sabor doce. Açúcar agrada o paladar infantil, e é pelo paladar que os alimentos conquistam as crianças. Nesse aspecto, o produto pertence a uma categoria de "cereais" cujo principal atrativo é o sabor aliado à crocância e em que as preocupações com o excesso de açúcar não estão presentes. Nesse discurso, comer açúcar é o comportamento eufórico, não o disfórico.

Esse ethos despreocupado e festivo da marca em relação ao sabor e ao teor de açúcar traz em si um discurso cuja origem é anterior às preocupações com o excesso de peso e a obesidade infantil. A atenção dada voluntariamente à saúde nessa embalagem restringe-se à informação nutricional complementar, que aparece ali como uma notícia boa, um tranquilizador da mãe que quer agradar a criança. $O$ aviso sobre os nutrientes funciona não como um alerta pró-saúde, mas como um endosso ao consumo de açúcar. A mensagem é: 'Fica tranquila, mãe. É doce, mas não é perigoso e é nutritivo'.

Uma das faces laterais da caixa traz a descrição do produto: "Flocos de milho açucarados enriquecido (sic) com vitaminas e minerais". Cabe notar que nessa pesquisa não foi comum encontrar a informação explícita sobre o enriquecimento na descrição do produto.

A face posterior da embalagem só não é idêntica à frontal por um detalhe: 0 símbolo dos transgênicos, acompanhado da inscrição vertical "contém milho transgênico", está na face posterior, pouco acima da logomarca do rodapé (Figura 35, detalhe do verso).

Não há direcionamento explícito para o significado desse símbolo, mas a aparente neutralidade da marca em relação aos transgênicos é relevadora de um posicionamento. A rotulagem de transgênicos é uma imposição do governo brasileiro (BRASIL, 2003, 2005) que incomoda a indústria (SALOMON, 2005). Então os rótulos, quando cumprem a lei, o fazem sem alarde, como se não tivessem nada a declarar. É uma forma de silenciar o debate, minimizar a polêmica, evitar o assunto. 
A interpretação que o consumidor fará da presença do símbolo dependerá do conhecimento que ele tem do símbolo e de tudo que lhe diz respeito. O sentido gerado pelo símbolo poderá ser de alerta se consumidor associá-lo a informações, conhecimentos e julgamentos que coloquem os transgênicos num lugar de algo indesejado ou temível. Poderá ser nenhum, caso o consumidor não perceba a presença do símbolo ou a ignore voluntariamente. Poderá ser o de uma informação neutra, sem qualquer carga emocional, ou ainda algo positivo, caso o consumidor seja entusiasta das novas tecnologias agrícolas. 


\section{EMBALAGEM 6}

A embalagem do "Muesli com frutas" da marca Dia apresenta um plano de expressão simples. Trata-se de um saco plástico inteiramente transparente, que permite ver o produto através da maior parte de sua superfície, com duas etiquetas de papel coladas do lado de fora, uma por cima da outra. Todas as informações disponíveis estão impressas nessas etiquetas (Figura 36, E).

A marca Dia não é brasileira. De origem espanhola, designa uma rede multinacional de supermercados com produtos de marca própria. A etiqueta de baixo tem um cabeçalho formado pela repetição do nome do produto em três idiomas: espanhol, francês e português de Portugal, ao lado da identidade visual da marca. A etiqueta original provavelmente se destina ao público europeu. Ela traz a lista de ingredientes nos mesmos idiomas do nome do produto e o símbolo do Ponto Verde, apresentado anteriormente.

Colada por cima da etiqueta europeia está uma outra, com a tradução para o português da lista de ingredientes, data de validade, tabela nutricional e peso líquido. A ordem dos ingredientes na lista traduzida difere da original, sendo que esta declara até os percentuais dos ingredientes na composição do produto, o que pode ser um fator de confusão caso o consumidor examine a etiqueta original. Não houve tradução ou substituição do símbolo da reciclagem por um com o qual o consumidor brasileiro esteja mais familiarizado. O peso líquido é a informação mais destacada dessa segunda etiqueta.

Na página do Dia do Brasil na internet é possível verificar que por baixo da etiqueta traduzida está a tabela nutricional da etiqueta estrangeira (Figura 36, D).

Considerando o que a legislação estipula como rotulagem obrigatória, podemos dizer que o rótulo do Muesli com frutas Dia informa apenas o indispensável. Não inclui alegações de propriedades nutricionais, não inclui imagens, não sugere modos de consumo, não fala bem de si mesmo, não tenta convencer o consumidor de coisa alguma. A comunicação publicitária nessa embalagem quase que se restringe à presença da marca Dia, cujo marketing está 
focado no preço, e fica para o consumidor a responsabilidade de ver o produto, conferir do que ele é feito e decidir se compra ou não.

Figura 36. Dia Muesli com frutas.
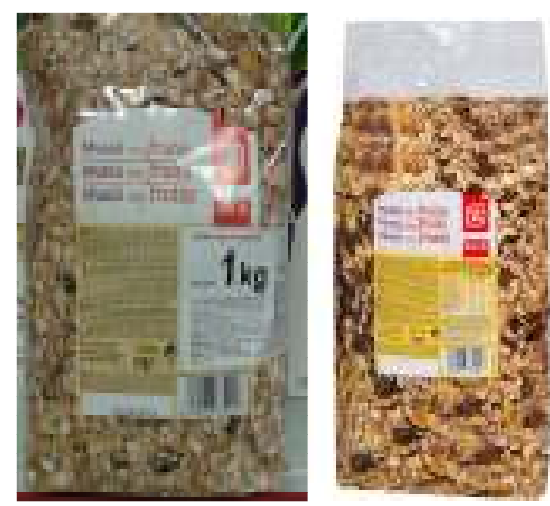

E: Imagem captada pela pesquisadora

D: Disponível em: http://www.dia.com.br/produtos.php?c=18

Podemos levantar a hipótese de que a quantidade de produto dentro da embalagem seja a informação que a marca julga ser mais relevante para seu público-alvo. A marca Dia posiciona-se no mercado como um varejo barateiro, destinado às classes de menor renda, o que justificaria a ênfase na economia que o consumidor faria ao adquirir uma embalagem com uma quantidade grande de produto. Na comparação com outras marcas, o consumidor perceberia que grande parte dos cereais matinais é vendida em embalagens de menos de 400 gramas e por preços maiores em relação ao peso. O destaque ao peso líquido seria, assim, uma forma de dizer "compre mais por menos".

Ao silenciar sobre quaisquer outros atributos do produto para além da relação peso x preço, a embalagem do Muesli com frutas Dia coloca-se no lugar de quem não vê necessidade de dizer mais nada e confia na autonomia do consumidor para decidir por conta própria, segundo seus próprios critérios, ou a partir das informações básicas que foram fornecidas.

Temos um aí um discurso sem texto. O plano de expressão é o próprio produto, que está exposto e pode ser julgado. Os sentidos gerados não virão de frases, números ou imagens, mas da memória presente nas características visíveis 
do produto. O consumidor verá flocos de cereais tostados e frutas secas e reconhecerá um produto que conhece e sabe se quer ou não, se o produto atende a suas necessidades e preocupações ou não. Não há relação de autoridade da marca sobre o consumidor. Talvez haja um coleguismo, uma relação de confiança semelhante à estabelecida pelo ethos aliado, mas é no reconhecimento silencioso que essa relação se constrói. 


\subsection{SÍNTESE}

A comunicação de marketing é uma das principais ferramentas utilizadas pelas grandes empresas para influenciar o comportamento dos consumidores. Observar como ela funciona é um caminho para entender que tipos de mensagens têm maior potencial para chamar atenção e modificar comportamentos num contexto em que a concorrência pela atenção dos consumidores é cada vez maior.

As estratégias usadas pelas marcas para conquistar o público e convencê-lo de que vale a pena comprar seu produto raramente se sustentam na transmissão de informação pura e simplesmente. A informação tende a vir acompanhada de um algo mais, algo que diga respeito a crenças e preferências do público-alvo. Segundo CRESCITELLI \& SHIMP (2012), os componentes simbólicos das embalagens cor, desenho, forma, tamanho, materiais físicos e informações - devem interagir em harmonia para evocar o conjunto de significados pela marca. O objetivo é que os consumidores reajam ao todo unificado, e não às partes individuais (p. 72).

Esse esforço das marcas em direção a uma interpretação unificada dos elementos comunicacionais das embalagens foi captado neste trabalho. Pudemos observar que a leitura das mensagens obedece a uma hierarquia criada pela marca e orientada pelo design. $\mathrm{O}$ trabalho criativo dos designers e publicitários é quem rege a atenção do consumidor-leitor diante de todo tipo de imagem, texto ou número apresentado, independentemente do que possam ter pretendido os legisladores.

A análise responde, portanto, a perguntas iniciais da pesquisa ao explicitar que, no processo de comunicação entre os emissores dos rótulos e os consumidores, há uma integração das mensagens publicitárias com as informações obrigatórias, com diferentes forças para cada qual conforme os objetivos da marca. As empresas de alimentos têm a capacidade de criar uma hierarquia para as mensagens nas embalagens e ressignificar as informações previstas na legislação conforme os seus interesses, podendo inclusive gerar uma diversidade de sentidos para um mesmo tipo de informação no objetivo de alcançar diferentes perfis de público. 
Em embalagens de ethos Anfitrião festivo, informações de teor negativo, castrador, tendem a ser ofuscadas pela pirotecnia e afetividade das mascotes, pois ali ninguém pode estragar o clima de alto astral. O símbolo dos transgênicos está presente, conforme obriga a legislação; a lei é cumprida. Mas isso não garante que a recepção dessa informação obrigatória será aquela imaginada por quem escreveu a lei, pois o designer da embalagem é livre para modular o volume dessa voz, reduzir a luz sobre esse falante, obedecendo ao seu maestro: o branding da marca.

O primeiro elemento ordenador dessa hierarquia das mensagens é o formato das embalagens. Nas caixas, que costumam ficar posicionadas verticalmente na prateleira e possuem quatro superfícies independentes e de tamanhos diferentes para a comunicação com o consumidor, a impressão das informações e a leitura estão culturalmente orientadas. $\mathrm{Na}$ face frontal, a mais visível, são impressas as mensagens que o fabricante julga mais importantes, o que inclui o nome, a marca e a informação visual que identifica o produto. É na face frontal das caixas que os fabricantes imprimem uma imagem idealizada e amplificada do produto, que substitui a visão do produto real, possível apenas através de embalagens concretamente transparentes. É com essa imagem idealizada, manipulada pelas tecnologias digitais e gráficas, que o consumidor se relaciona primeiro. É nela que ele confia para fazer sua primeira escolha, é ela que ele escolhe. O que ele compra é uma imagem, uma ideia, uma versão fictícia, imaginária do produto. O produto e simbólico, não é real. Compra-se uma simbologia.

As mensagens um pouco menos prioritárias aparecem na face posterior. Às faces laterais, superior e inferior, que são menores e ficam menos à vista, são destinadas as informações secundárias e as mensagens complementares que reforçam o que está dito nas superfícies maiores da caixa. É nessas faces "mais escondidas" que costumam vir as informações obrigatórias, como a tabela nutricional, a data de validade, o endereço da fábrica, entre outras. Em suma: a informação que interessa é apartada da vista, reduzida, tornada secundária, enquanto as imagens hiperbólicas têm espaço de sobra e são mantidas em primeiro plano.

Nas embalagens mais simples, como os sacos plásticos transparentes com uma única etiqueta impressa sobre o plástico, o espaço de impressão das mensagens 
é mais restrito, com menos possibilidades de modulação da leitura. No corpus estudado, esse tipo de embalagem tende a ser adotado por marcas de ethos Aliado ou aquelas mais silenciosas, que preferem não dizer muito e deixam o consumidor decidir por conta própria com base em seus conhecimentos. As embalagens plásticas, diferentemente das caixas, permitem que o consumidor tenha um contato mais real com o produto antes da decisão de compra.

Assim, a informação nutricional, embora obedeça a um padrão estabelecido pela legislação, tem posições hierárquicas diferentes e gera significados diferentes conforme o contexto em que é apresentada. Nas embalagens de ethos Ídolo, em que o público-alvo é infanto-juvenil, ela se coloca como um vínculo remanescente entre a autoridade carinhosa da mãe e a criança que quer crescer. Não é a mensagem mais importante, mas não é inteiramente apagada. Fica ali, se fazendo presente, garantindo a segurança e mantendo o vínculo, mas em segundo plano, deixando que o prazer de tornar-se independente fale mais alto.

É nas embalagens em que o ethos Especialista predomina que a leitura da informação nutricional é mais favorecida, na comparação com embalagens de outros ethe. Mas ela tende a não aparecer de forma isolada nem objetiva. Ela vem embalada no discurso da marca, a serviço da marca, com a função de fortalecer a imagem da marca como autoridade em saúde e provedora confiável de alimentos que fazem bem.

Vimos que algumas marcas se revestem da memória do carinho maternal para orientar o consumo usando um vocabulário emprestado da ciência da nutrição. Quando a marca assume o discurso materno para orientar as escolhas do consumidor-alvo, mesmo sem se materializar na figura materna, ela se apropria de uma simbologia universal que fala diretamente ao coração dos filhos. Ainda que o assunto seja a ingestão de nutrientes, ainda que a origem da informação seja científica, vestida em avental branco, é a voz da mãe que o consumidor ouve.

Posicionada assim, discursivamente, a informação nutricional funciona inclusive para silenciar outras informações relevantes sobre o produto. Com frequência, o destaque ao teor de fibras e de micronutrientes adicionados desvia a atenção do excesso de açúcar. Em alguns casos, o destaque aos nutrientes adicionados silencia o baixo teor de fibras e o grau de processamento dos cereais. 
Na comunicação de marketing, a informação pode ser apresentada de modo que adquira um caráter simbólico. Aí, a simbologia passa a ter mais valor que o dado fornecido. Foi o que a Nestlé fez ao transformar em marca a informação sobre a presença de cereal integral em seus produtos. O que poderia ser uma informação objetiva, verificável em diferentes produtos, passa a ser a manifestação de uma legitimidade construída pela própria imagem da marca. Nenhuma autoridade de saúde deu diretamente à Nestlé o aval para se colocar como orientadora de dietas, mas o modo como a marca se apresenta, o seu ethos, é aceito como legitimador de seu discurso. Segundo BOURDIEU (2010), esse poder simbólico,

\begin{abstract}
poder quase mágico que permite obter o equivalente daquilo que é obtido pela força (física ou económica), graças ao efeito específico de mobilização, só se exerce se for reconhecido, quer dizer, ignorado como arbitrário. (...) O que faz o poder das palavras e das palavras de ordem, poder de manter a ordem ou de a subverter, é a crença na legitimidade das palavras e daquele que as pronuncia, crença cuja produção não é da competência das palavras (BOURDIEU, 2010, p. 14-15).
\end{abstract}

A simbologia que interessa às marcas é aquela que faz sentido para seus diferentes perfis de público. $\mathrm{Na}$ comunicação de marketing, todas as ações são segmentadas, ou seja, direcionadas a um público-alvo específico. "A segmentação permite que os gestores de comunicação de marketing transmitam suas mensagens com precisão e evita que se desperdicem esforços abordando aqueles que não fazem parte do público-alvo" (CRESCITELLI \& SHIMP, 2012, p. 88). Por isso a embalagem de Nestlé Crunch fala com o pré-adolescente que quer se sentir crescido; a do Dia Cereal Açucarado fala com a criança que ainda não quer crescer; a da granola Mãe Terra conversa especificamente com quem quer se sentir um consumidor mais consciente e responsável; a do Dia Muesli com frutas fala com quem não quer ser incomodado.

Nesse sentido, se for objetivo da saúde pública modular a comunicação com o público segundo uma hierarquia menos favorável ao marketing privado, será pertinente o questionamento, no âmbito dos órgãos regulatórios, sobre a necessidade de regular não apenas o teor das mensagens textuais nos rótulos, mas também o uso de imagens, símbolos, diagramas, ilustrações e demais recursos gráficos. 
Pudemos observar que, no corpus examinado, a formação dos sujeitos da enunciação obedece à necessidade de gerar empatia com o público-alvo. $O$ principal sujeito enunciador é quase sempre a marca-fabricante do produto, revestida de uma roupagem que traz da memória a figura de alguma entidade conhecida, que faz parte do contexto social do consumidor-enunciatário, tal como a mãe, a avó, um amigo admirado. As marcas buscam incessantemente a identificação do público. Buscam falar a língua do público, com seus códigos linguísticos e morais. Colocam-se no lugar de quem é igual, portanto confiável. Quem fala com o público, aos olhos e ouvidos idealizados do público, é alguém já legitimado, previamente aceito e aprovado, dotado do direito de ser ouvido.

Uma hipótese que essa constatação levanta é que falar desse lugar normalizado, familiarizado, é diferente de tentar ser ouvido do lugar do estranho, do forasteiro, do estrangeiro, de quem vem de fora com um discurso autoritário ou destoante, codificado, difícil de entender, porque faz parte de outra cultura. É pertinente desconfiar que discursos da saúde ou da sustentabilidade que não se revistam do que é familiar ao público, do que é esperado por ele, correm o risco de não serem ouvidos. É recomendável, portanto, testar se uma roupagem mais amigável para as mensagens da saúde pública é capaz de conquistar a empatia dos mais diversos públicos, assim como fazem as empresas de alimentos.

As embalagens analisadas permitem constatar também que, de modo geral, a comunicação se dirige ao indivíduo. O sujeito interlocutor, embora inserido num contexto social, é individual. A comunicação nos rótulos destina-se a influenciar uma decisão de consumo particular, privada, independente do coletivo. O máximo de coletividade presente nessa comunicação é o núcleo familiar, quando o consumidor-alvo do produto é a criança. Mesmo nas embalagens de ethos Aliado, o consumo incentivado nas mensagens é individual.

Isso nos traz outra questão que vale uma reflexão. Será que essa relação entre sujeitos estabelecida na comunicação entre marcas de alimentos e consumidores é tão individualista que toda alteridade está silenciada? Será possível trazer para essa comunicação a questão do consumo cidadão, da sustentabilidade, sem romper com essa troca espelhada de mensagens em que apenas o eu-receptor parece ter voz? De 
que forma será possível gerar essa identificação, essa empatia, e ao mesmo tempo promover um consumo mais consciente em relação ao outro?

A comunicação nas embalagens no Brasil ainda está longe de engajar o público para um consumo de alimentos mais sustentável. Os poucos selos certificadores e símbolos que aparecem, na maioria dos casos, não dão conta de informar nem de incentivar práticas mais conscientes. Apenas o grupo de embalagens de ethos Aliado, principalmente de produtos orgânicos, tende a dar mais atenção ao consumo "verde".

Nas embalagens de ethos Aliado, as informações sobre saúde e sustentabilidade vêm envoltas no discurso do politicamente correto do momento, em que os cuidados com a saúde e o planeta valorizados pelo público-alvo são elevados a um patamar superior, com o qual esse público-alvo deseja se identificar. $\mathrm{Na}$ embalagem da Mãe Terra analisada, a informação nutricional é mesclada com as mensagens sobre a ausência de ingredientes indesejados e o caráter natural do produto, de modo que o conceito de alimentação saudável resultante seja mais abrangente do que o previsto na tabela nutricional. A informação nutricional está lá, como deve estar, mas a mensagem de saúde está mais associada aos ingredientes usados do que aos nutrientes, o que reflete um posicionamento mais alinhado às recomendações do guia alimentar brasileiro de 2014. Além disso, toda informação sobre impactos ambientais é apresentada afetivamente, com o intuito de mobilizar, engajar o público em torno de uma causa nobre. Para informar, bastariam talvez alguns selos certificadores ou dados numéricos. Mas a preocupação dos designers das embalagens de ethos Aliado é mais engajar do que informar. E esse é um dado muito relevante para nossa análise.

A estratégia comunicacional das embalagens da Mãe Terra, ainda que com limitações e independentemente da qualidade de seus produtos, demonstra grande potencial para explorar o conceito de alimentação saudável que interessa à nossa política alimentar. Entre seus trunfos estão: o uso da primeira pessoa do plural como elemento convidativo; a integração das mensagens sobre saúde, sustentabilidade de cultura numa linguagem textual e não textual coesa; e o forte apelo afetivo dessa linguagem, que foge ao padrão cientificista dos gráficos quantitativos. 
Essa associação entre informação objetiva e dura com afeto, com significados que apelam para as emoções, que a comunicação de marketing usa com tanta eficácia, talvez seja a chave para uma comunicação mais efetiva entre a ciência da nutrição e os consumidores, como sugere o estudo de GRABENHORST et al (2013). É algo que deve checado em novos estudos.

Se informação objetiva não é suficiente para modificar o comportamento alimentar, ela também não neutraliza a mensagem do marketing. HARRIS et al (2009) afirmam que é incorreta a suposição de que um maior conhecimento sobre nutrição e saúde e sobre o intento persuasivo da comunicação de marketing seja capaz de neutralizar os efeitos dessa comunicação. Um dos motivos é que as mensagens da propaganda nem sempre são percebidas por meio da desatenção. No caso de crianças, elas também podem ser captadas enquanto a pessoa está desatenta.

HARRIS et al (2009) listam evidências de que as técnicas da comunicação de marketing são altamente eficazes como marcadoras de memória. Uma criança de dois anos já é capaz de reconhecer uma logomarca. Tal eficácia se explica em grande medida pelo caráter emocional da publicidade. Os pesquisadores também enumeram teorias e modelos para entender as diferenças na absorção dos valores da propaganda por crianças e adolescentes, conforme a idade. E reconhecem que a inovação nas técnicas usadas pela comunicação de marketing - fundamentada em estudos psicológicos cada vez mais sofisticados - é tão bem-sucedida que seria conveniente que os defensores da saúde pública buscassem se aprimorar na mesma medida. "Já que os marqueteiros usam teorias e métodos psicológicos para examinar o que funciona, a necessidade de pesquisa psicológica para examinar como se defender das práticas efetivas do marketing se torna ainda mais crítica" (HARRIS et al, 2009, p 25).

No mesmo artigo, HARRIS et al (2009) sugerem que mais estudos testem a hipótese de que abordagens criativas de marketing semelhantes às utilizadas para promover alimentos não saudáveis podem ser igualmente efetivas na promoção de alimentos saudáveis (p. 30). Mas não devemos confundir a promoção de alimentos saudáveis com a propaganda de produtos e marcas específicos. Uma resolução do Conselho Nacional dos Direitos da Criança e do Adolescente (Conanda), de março de 2014, considera abusiva toda forma de publicidade direcionada à criança, 
incluindo a presença de mascotes nas embalagens dos alimentos (SDH, 2014). O uso de linguagem infantil, efeitos especiais, excesso de cores, representação de criança, pessoas ou celebridades com apelo ao público infantil, personagens ou apresentadores infantis, desenho animado ou de animação, bonecos ou similares, promoção com distribuição de prêmios ou de brindes colecionáveis ou com apelos ao público infantil e promoção com competições ou jogos com apelo ao público infantil está proibido.

No que concerne ao público adulto, convém não assumir ingenuamente que a embalagem mais propícia às mensagens da saúde pública será aquela que não diz nada ou quase nada além do obrigatório, como a do Dia Muesli com frutas. Embora silencie as vozes do marketing, o que pode soar como um silêncio propício, esse tipo de embalagem silencia também as vozes capazes de abrir ouvidos distraídos. Embalagens assim tão silenciosas têm potencial para comunicar-se apenas com quem, por hábito, já decodifica seus significados. Engajar o público e promover um consumo mais atento entre consumidores que ainda não o buscam por conta própria, como defendem MACRAE et al (2012), requer uma comunicação minimamente barulhenta.

Esse argumento também vale para confrontar a tese de que a promoção da alimentação saudável deveria afastar qualquer preocupação em melhorar a rotulagem de alimentos, já que os alimentos embalados tendem a ser mais os processados, e que portanto o certo seria incentivar apenas o consumo de alimentos não embalados. Não se pode ignorar que as embalagens, por mais simples que sejam, estão presentes em todos os segmentos do mercado de alimentos, desde os ultraprocessados até os alimentos in natura e minimamente processados, como frutas frescas, grãos e sementes integrais, incluindo arroz e feijão. Não é ignorando a presença das embalagens nas práticas mercadológicas e de consumo que iremos resolver o problema da promoção da saúde. Ao contrário, devemos aproveitar os conhecimentos disponíveis sobre comunicação e nos apropriar das técnicas mais eficazes em prol dos objetivos da saúde pública. As embalagens são meios de comunicação poderosos e devem ser mais bem utilizadas para fins informacionais e educativos. 
Estudos culturais, sociológicos, antropológicos e psicológicos, entre outros, serão úteis para determinar que tipos de mensagem e que tipos de linguagem terão maior potencial para engajar o consumidor de cada região brasileira, cada estrato social. FURST et al (2000) salientam que a promoção de padrões alimentares saudáveis que façam sentido para o público deve levar em conta o modo como as pessoas, e apenas não os nutricionistas, classificam os alimentos. Citando diversos artigos, os autores afirmam que as classificações normalmente adotadas pelas pessoas comuns costumam refletir sistemas de crenças sobre os alimentos que diferem da visão dos profissionais.

As classificações dos alimentos pelas pessoas podem ser culturalmente
simbólicas, tais como refeições de férias ou para ocasiões especiais, ou
alimentos percebidos como adequados para determinada refeição, como
o café da manhã; focadas na sensação, ao longo de dimensões do tipo
"salgado/doce" ou "gostoso/ruim"; baseadas no que a pessoa considera
"saudável/não saudável"; ou categorizadas de acordo com grupos de
alimentos como "vegetais" ou "amidos" (FURST et al, 2000).

Um dado curioso: na pesquisa qualitativa de FURST et al (2000) com o público americano, a maioria dos entrevistados categorizou os alimentos de acordo com a dimensão fresco/processado, mas os significados atribuídos a "fresco" e "processado" foram às vezes muito diferentes. O termo "fresco" foi mais comumente usado para categorizar frutas e hortaliças, especialmente aquelas que se acreditava não terem passado por nenhum processamento. Mas o termo também foi usado em frases sobre comida feita pela própria pessoa, em casa, mesmo que processada, como comida congelada ou conservas.

Outro resultado interessante do estudo foi que as classificações podiam mudar conforme o contexto físico e social. Um mesmo alimento podia ser classificado segundo dimensões variadas (familiar, gostoso, nutritivo, barato, da época). Os autores concluem que "significados precisam ser refletidos e explorados dentro de um processo dialógico".

GARCIA (1997) estudou as representações sociais da alimentação no discurso de funcionários públicos do município de São Paulo (SP) “com o intuito de compreender como as informações sobre alimentação associadas à saúde são incorporadas pelo sujeito, de modo que ele as integre ao seu repertório (...) e também as utilize como balizadora de suas práticas alimentares". Na pesquisa, 
testou o uso de termos como "alimentação", "nutrição" e "comida", que não têm o mesmo efeito no uso cotidiano. As duas primeiras palavras, diz a autora, "condizem com o enfoque da norma, da dieta regulada". Já "comida" se liga com as percepções e recupera e elementos da experiência pessoal e social. A conclusão do estudo foi que "as informações não são elementos preponderantes na determinação do comportamento alimentar" e que a coerência de certas atitudes das pessoas com relação à alimentação e saúde/doença pode ser apenas circunstancial.

A autora considerou como comportamento alimentar tanto as práticas observadas empiricamente (o que comemos; quanto comemos; como, quando e na companhia de quem comemos e onde comemos) quanto aspectos subjetivos socioculturais e psicológicos, tais como os alimentos e preparações considerados apropriados para cada situação; comida desejada e apreciada de fato e que as pessoas gostariam de apreciar; ou a quantidade de comida que as pessoas pensam comer.

\begin{abstract}
Através da comunicação, o objeto, quer seja humano, social, material ou uma ideia, será apreendido a partir de uma lente impregnada de valores e conceitos significantes já existentes na bagagem histórica do sujeito; ou seja, o objeto é selecionado e integrado numa rede que traduz algo significante para o sujeito. A aproximação da realidade externa, de modo a torná-la próxima e perceptível, é uma facilidade proporcionada pelas representações, trazendo o mundo externo para o repertório pessoal do indivíduo. Assim, um conceito, uma abstração, passa a ter uma existência real através da apropriação destes pelas representações sociais, consideradas uma forma de conhecimento do senso comum, elaborado e compartilhado socialmente (GARCIA, 1997).
\end{abstract}

FONSECA et al (2011) defendem uma abordagem qualitativa para compreender o fenômeno alimentar e o seu consumo e avançar na construção do conhecimento na ciência nutricional. LUCCHESE-CHEUNG et al (2012), que estudaram comportamentos de consumo de alimentos em Porto Alegre, São Paulo, Goiânia e Recife, também observaram que os alimentos são impregnados de significados simbólicos e como tais são difusores de identidades sociais, contribuindo no processo de construção dessas identidades. Os autores recomendam, a quem pretenda promover reeducação alimentar, investigar como as pessoas percebem os alimentos, suas necessidades cotidianas, seus sistemas de valor. 
Esses estudos nos alertam para a importância de adaptar a linguagem da comunicação com os consumidores conforme o vocabulário e os sentidos que já fazem parte de sua cultura. No que diz respeito à rotulagem de alimentos, é preciso experimentar modos de transmitir a mensagem da nutrição - em toda a amplitude que os teóricos da nova ciência da nutrição propõem - que não enfrentem obstáculos linguísticos, culturais ou matemático-intelectuais. É preciso falar a língua do público para que ele ouça, aceite, entenda e acolha a mensagem que se deseje transmitir. E isso não depende de um ensino básico especializado em nutrição, mas de um interesse genuíno em comunicar melhor.

Assim, futuros estudos de recepção deveriam não apenas medir o grau de entendimento e aproveitamento da informação disponível nos rótulos, mas levantar de que formas o público absorve melhor o conteúdo que se pretende comunicar. 


\subsection{PROPOSTAS}

O terceiro objetivo específico deste trabalho foi elaborar propostas para o fortalecimento do discurso da saúde na rotulagem de alimentos. Os dados apresentados e discutidos na revisão bibliográfica e na análise empírica das embalagens levantam questões sobre: o efeito do uso de mascotes; a especificidade da linguagem conforme o público-alvo; o uso de tecnologias digitais; o destaque a atributos de sabor em alimentos saudáveis; o uso de linguagens simples e intuitivas; a clareza quanto ao significado dos esquemas numéricos e gráficos utilizados; a transparência; a midiatização dos sentidos do consumo; a hierarquia das mensagens; os interesses mercadológicos; os significados pretendidos pela saúde pública, entre outros.

Decidiu-se então formular hipóteses sobre um melhor funcionamento da comunicação nos rótulos que possam ser verificadas em novos estudos. Tais hipóteses refletem as conclusões a que o cruzamento dos resultados da pesquisa permite chegar. Se confirmadas, poderão dar suporte a uma reformulação radical da rotulagem de alimentos. Eis as hipóteses formuladas:

- A lista de ingredientes, quando posicionada de forma destacada na embalagem, em fonte indiscutivelmente legível, é mais facilmente percebida e utilizada pelo consumidor do que nas posições e tamanhos em que costuma estar.

- Informação clara e precisa sobre a proporção de cada ingrediente do produto é mais útil para escolhas mais saudáveis do que a forma atual de apresentação dos ingredientes nos rótulos.

- O consumidor tem mais facilidade para fazer escolhas mais saudáveis quando os ingredientes são declarados em grupos separados: 1) itens alimentícios conhecidos do consumidor comum; 2) misturas, preparados, polpas processadas e demais ingredientes de uso exclusivamente industrial; e 3) aditivos alimentares. 
- A informação sobre o grau de processamento do alimento na embalagem ajuda o consumidor a fazer escolhas mais saudáveis.

- A informação sobre impactos ambientais do alimento ou produto alimentício associada à informação sobre impactos na saúde ajuda o consumidor a fazer escolhas mais saudáveis.

- O consumidor presta mais atenção à informação nutricional quando ela está posicionada na parte da frente da embalagem, de forma destacada em relação aos demais elementos comunicacionais no entorno.

- O consumidor entende melhor a informação sobre quantidades (tamanho da porção, proporção de ingredientes e nutrientes) quando estas são expressas na forma de imagens ou gráficos simples do que quando expressas em números.

- A informação nutricional se torna mais clara e útil para o consumidor quando compara a composição do produto pronto para o consumo com um alimento integral de referência.

- Condicionar o uso de alegações nutricionais tais como "rico em fibras" à apresentação de alimentos integrais de referência para os valores nutricionais valorizados nas alegações ajuda o consumidor a fazer escolhas mais saudáveis.

- Em produtos enriquecidos, condicionar o uso de alegações nutricionais tais como "rico em vitaminas" a um aviso sobre como o enriquecimento ajuda o consumidor a fazer escolhas mais saudáveis.

- O consumidor tende a dar mais atenção à informação sobre os impactos do alimento ou produto na saúde e na sustentabilidade quando esta é destacada por meio de estratégias comuns à comunicação de marketing, tais como frasesconvite, slogans, frases de efeito, ícones, ilustrações, imagens, mascotes, cores chamativas, fontes grandes e relevo, entre outros.

Tais hipóteses poderão ser testadas em combinações diversas, com a finalidade de verificar em que medida cada uma dessas intervenções nos rótulos pode modificar o modo de leitura pelos consumidores. Além das áreas de pesquisa já citadas, estudos sobre legibilidade, da área de editoração, também poderão ser de grande valia para o cálculo das proporções mais adequadas entre os elementos comunicacionais das embalagens. 


\section{CONCLUSÃO}

Uma das principais contribuições deste trabalho é a evidência de que as pesquisas na área da ciência da nutrição voltadas à promoção da alimentação saudável podem se beneficiar de uma maior integração com pesquisas nas áreas de comunicação e linguagem. O estudo da comunicação com o consumidor via rótulos de alimentos mostrou ser de grande relevância para o campo de comunicação e saúde, com muitas questões a serem resolvidas.

Este é possivelmente um trabalho pioneiro na área de nutrição, por aplicar o método da análise qualitativa do discurso à emissão de rótulos de alimentos. Esse pioneirismo implica grandes desafios. Transpor uma metodologia de análise típica de estudos de comunicação à área de nutrição em saúde pública sem um modelo a seguir significou experimentar caminhos metodológicos novos, o que envolve riscos maiores do que aplicar métodos de pesquisa usuais da área.

A revisão da literatura específica deu suporte à análise empírica das embalagens e à elaboração de propostas para novos estudos ao trazer evidências dos problemas comunicacionais no modelo de rotulagem utilizado hoje e apontar caminhos de pesquisa ainda pouco explorados.

Apesar da falta de modelos para a adequação das bases teóricas e metodológicas ao objeto de estudo e das dificuldades no estudo da teoria, a aplicação da análise do discurso tal como foi utilizada mostrou-se viável e útil. Ela favoreceu o entendimento de como a linguagem interfere na emissão e na recepção das mensagens, como as ideologias encontram lugar nas linguagens, como as embalagens se relacionam com as práticas de consumo e por que é preciso controlar melhor a emissão das mensagens nas embalagens a fim de transmitir com êxito os conteúdos desejados pela política alimentar.

A elaboração de hipóteses para novos estudos foi facilitada pela revisão bibliográfica e pela análise empírica em conjunto. 
É possível afirmar que os métodos de investigação utilizados neste trabalho podem ser aplicados na análise de outras categorias de produtos. Novos estudos se beneficiarão de uma maior integração de conhecimentos de áreas diversas e complementares como nutrição, sustentabilidade, economia, psicologia, design e comunicação social.

Quanto ao papel da rotulagem de alimentos na promoção da alimentação saudável, podemos concluir que ele será favorecido não apenas por uma melhor atenção aos seus aspectos comunicacionais, como também pela adequação da legislação e dos processos decisórios ao conceito de alimentação saudável previsto na PNAN.

As normas para rotulagem de alimentos em vigor no Brasil hoje, criadas de forma não integrada por diversos órgãos governamentais, favorecem o nutricionismo e deixam de lado aspectos importantes da saúde e da sustentabilidade. Além disso, permitem que os efeitos da comunicação nas embalagens sejam modulados pelas marcas de alimentos, que têm liberdade para utilizar recursos gráficos competitivos, capazes de reduzir ou anular os efeitos das informações obrigatórias, que por sua vez são intrinsecamente prejudicadas pela linguagem técnica.

A informação nutricional sozinha não é um instrumento efetivo de promoção da alimentação saudável, e por isso não deve ser tratada pela legislação como se o fosse. É preciso considerar que o consumidor-leitor não irá acessar de forma isolada a informação nutricional impressa em linguagem técnica e que todos os elementos gráficos e tridimensionais das embalagens competem pela atenção do público. A atenção dos consumidores não irá se direcionar às questões da sustentabilidade na alimentação se estas não forem apresentadas de modo mais claro, visível ou mesmo contundente.

Para que a rotulagem de alimentos se torne um instrumento efetivo de promoção da alimentação saudável, é preciso que a comunicação do conceito de alimentação saudável proposto pela PNAN via rótulos seja pensada em todos os seus aspectos. A legislação deve prever a transmissão de informações mais abrangentes e completas e controlar o impacto que tais informações deverão alcançar. É preciso criar normas e estratégias que aumentem a chance de o 
consumidor perceber e entender as mensagens que promovem a alimentação saudável em todas as suas dimensões, colocando-as num lugar superior na hierarquia das mensagens.

Não basta imprimir uma informação e torcer para que todos saibam aproveitála; é preciso comunicar bem. 


\section{REFERÊNCIAS}

Achbar M, Abbott J, directors, Bakan J, writer. The corporation [filme]. British Columbia: Big Picture Media Corporation; 2003 [acesso em 26 dez 2012]. Disponível em: http://www.youtube.com/watch?v=Y888wVY5hzw

Agência Brasil. Frutas e hortaliças terão rótulo obrigatório a partir de hoje. Brasília (DF): Empresa Brasil de Comunicação; 15 mar 2004 [acesso em 15 jan 2013]. Disponível em: http://agenciabrasil.ebc.com.br/noticia/2004-03-15/partir-de-hojefrutas-e-hortalicas-tem-rotulagem-obrigatoria

Ahmadi A, Torkamani P, Sohrabi Z, Ghahremani F. Nutrition knowledge: application and perception of food labels among women. Pak J Biol Sci. 2013 Dec 15;16(24):2026-30.

Albert $\mathrm{J}$, editor. Innovations in food labeling. Oxford [u.a.]: Food and Agriculture Organization of the United Nations/ Woodhead Publ; 2010.

Anvisa - Agência Nacional de Vigilância Sanitária. Resolução no ${ }^{\circ}$ 18, de 30 de abril de 1999. Aprova o Regulamento Técnico que estabelece as diretrizes básicas para análise e comprovação de propriedades funcionais e ou de saúde alegadas em rotulagem de alimentos. Diário Oficial da União; 3 maio 1999 [acesso em 3 nov 2012]. Disponível em: http://bit.ly/1oO5Xcu

Anvisa - Agência Nacional de Vigilância Sanitária. RDC n ${ }^{\circ} 40$, de 8 de fevereiro de 2002. Aprova o Regulamento Técnico para rotulagem de alimentos e bebidas embalados que contenham glúten, constante do anexo desta Resolução. Diário Oficial da União; 13 fev 2002a [acesso em 4 nov 2012]. Disponível em: http://bit.ly/1nBTiZ8

Anvisa - Agência Nacional de Vigilância Sanitária. Resolução RDC nº 259, de 20 de setembro de 2002. Aprova o Regulamento Técnico sobre Rotulagem de Alimentos Embalados. Diário Oficial da União; 23 set 2002b [acesso em 4 nov 2012]. Disponível em:

http://portal.anvisa.gov.br/wps/wcm/connect/36bf398047457db389d8dd3fbc4c673 5/RDC_259.pdf?MOD=AJPERES

Anvisa - Agência Nacional de Vigilância Sanitária. Resolução RDC nº 360, de 23 de dezembro de 2003. Aprova Regulamento Técnico sobre Rotulagem Nutricional de Alimentos Embalados, tornando obrigatória a rotulagem nutricional. Diário Oficial da União; 26 de dez 2003 [acesso em 4 nov 2012]. Disponível em: http://bit.ly/1bKscPs 
Anvisa - Agência Nacional de Vigilância Sanitária. RDC $n^{0}$ 54, de 12 de novembro de 2012. Dispõe sobre o Regulamento Técnico sobre Informação Nutricional Complementar. Diário Oficial da União; 13 nov 2012a [acesso em 30 nov 2012]. Disponível em: http://bit.ly/WfGB0C

Anvisa - Agência Nacional de Vigilância Sanitária. Perguntas e respostas sobre Informação Nutricional Complementar (INC). Brasília (DF); nov 2012 b [acesso em 30 nov 2012]. Disponível em: http://bit.ly/1wROMev

Anvisa - Agência Nacional de Vigilância Sanitária. Alimentos / Assuntos de Interesse / Legislação [internet]. Brasília (DF); 2005-2009 [acesso em 6 jan 2013]. Disponível em: http://bit.ly/1qx7rik

Anvisa - Agência Nacional de Vigilância Sanitária. Medicamentos/ Publicação Medicamentos [internet]. Brasília (DF); s/d - a [acesso em 21 jul 2014]. Disponível em: http://s.anvisa.gov.br/wps/s/r/bav

Anvisa - Agência Nacional de Vigilância Sanitária. Alimentos / Assuntos de Interesse / Relações Internacionais [internet]. Brasília (DF); s/d - b [acesso em 21 jul 2014]. Disponível em: http://s.anvisa.gov.br/wps/s/r/cDb

Anvisa - Agência Nacional de Vigilância Sanitária. Portaria no 949 , de 4 de junho de 2014. Institui Grupo de Trabalho na ANVISA para auxiliar na elaboração de propostas regulatórias relacionadas à rotulagem nutricional. [acesso em 21 jul 2014]. Disponível em: http://bit.ly/1p2U7LX

Ares G, Giménez A, Bruzzone F, Vidal L, Antúnez L, Maiche A. Consumer Visual Processing of Food Labels: Results from an Eye-Tracking Study. Journal of Sensory Studies. 2013; 28 (2): 138-53.

Aschemann-Witzel J, Grunert KG, van Trijp HC, Bialkova S, Raats MM, Hodgkins C, Wasowicz-Kirylo G, Koenigstorfer J. Effects of nutrition label format and product assortment on the healthfulness of food choice. Appetite. 2013 Dec;71:6374.

ATNI - Access To Nutrition Index. Methodology Development Report: August 2012. Geneva: Access To Nutrition Index; 2012 [acesso em 27 ago 2012]. Disponível em: http://www.accesstonutrition.org/the-index

Azevedo E. Riscos e controvérsias na construção social do conceito de alimento saudável: o caso da soja. Rev. Saúde Pública. 2011;45(4):781-8. DOI: $10.1590 / \mathrm{S} 0034-89102011000400019$ 
Balcombe K, Fraser I, Di Falco S. Traffic lights and food choice: A choice experiment examining the relationship between nutritional food labels and price. Food Policy. 2010; 35:211-20.

Banterle A, Cavaliere A, Ricci EC. Food Labelled Information: An Empirical Analysis of Consumer Preferences. Int. J. Food System Dynamics. 2012;3(2):15670 .

Barthes R. Toward a psychosociology of contemporary food consumption. In: Counihan C \& Van Esterik P. Food and culture: a reader. London: Routledge, 1997.

Beauman C, Cannon G, Elmadfa I, Glasauer P, Hoffmann I, Keller M, Krawinkel M, Lang T, Leitzmann C, Lötsch B, Margetts B, McMichael T, Meyer-Abich K, Oltersdorf U, Pettoello-Mantovani M, Sabaté J, Shetty P, Sória M, Spiekermann U, Tudge C, Vorster E, Wahlqvist M, Zerilli-Marimo M. The Giessen Declaration. Public Health Nutrition. 2005; 8(6A): 783-6. DOI: 10.1079/PHN2005768

Bellatti A, Simon M. Regulating Front of Package Labeling: An Exercise in Futility? Journal of Hunger \& Environmental Nutrition. 2011; 6:4, 513-23

Bendino NI, Popolim WD, Oliveira CRA. Avaliação do conhecimento e dificuldades de consumidores frequentadores de supermercado convencional em relação à rotulagem de alimentos e informação nutricional. J Health Sci Inst. 2012;30(3):261-5.

Bialkova S1, Grunert KG2, Juhl HJ2, Wasowicz-Kirylo G3, Stysko-Kunkowska M3, van Trijp H4. Attention mediates the effect of nutrition label information on consumers' choice. Evidence from a choice experiment involving eye-tracking. Appetite. 2014 Feb 3.

Bittman M. My Dream Food Label. The New York Times. Sunday Review - The Opinion Pages. 2012 Out 13. Disponível em: http://nyti.ms/1mlIuOm

Bonanni AE, Bonaccio M, Castelnuovo A, Lucia F, Costanzo S, Persichillo M, Zito F, Donati MB, Gaetano G, Iacoviello L. Food Labels Use Is Associated with Higher Adherence to Mediterranean Diet: Results from the Moli-Sani Study. Nutrients. 2013; 5: 4364-79.

Bonsmann SS, Celemín LF, Grunert KG; FLABEL consortium. Food labelling to advance better education for life. Eur J Clin Nutr. 2010 Nov;64 Suppl 3:S14-9.

Borra S. Consumer perspectives on food labels. Am J Clin Nutr. 2006;83(suppl):1235S. 
Botti S, \& Broniarczyk S, Häubl G, Hill R, Huang Y, Kahn B, Kopalle P, Lehmann D, Urbany J, Wansink B. Choice under restrictions. Market Lett. 2008; 19:183-99. DOI 10.1007/s11002-008-9035-4

Bourdieu P. O poder simbólico. Rio de janeiro: Bertrand Brasil, 2010.

Brait B, organizadora. Bakhtin: outros conceitos-chave. São Paulo: Contexto, 2008.

Brasil. Lei $n^{\circ}$ 6.437, de 20 de agosto de 1977. Configura infrações à legislação sanitária federal, estabelece as sanções respectivas, e dá outras providências. Diário Oficial da União; 24 ago 1977 [acesso em 2 nov 2012]. Disponível em: http://www.anvisa.gov.br/legis/consolidada/lei_6437_77.pdf

Brasil. Decreto $\mathrm{n}^{\mathrm{o}} 4.680$, de 24 de abril de 2003. Regulamenta o direito à informação, assegurado pela Lei no 8.078, de 11 de setembro de 1990, quanto aos alimentos e ingredientes alimentares destinados ao consumo humano ou animal que contenham ou sejam produzidos a partir de organismos geneticamente modificados, sem prejuízo do cumprimento das demais normas aplicáveis. Diário Oficial da União; 25 abr 2003 [acesso em 13 dez 2012]. Disponível em: http://portal.anvisa.gov.br/wps/wcm/connect/1938f70047457fd28b9edf3fbc4c6735/ DECRETO_4680.pdf?MOD=AJPERES

Brasil. Lei $\mathrm{n}^{\mathrm{o}}$ 11.105, de 24 de março de 2005. Regulamenta os incisos II, IV e V do $\S 10$ do art. 225 da Constituição Federal, estabelece normas de segurança e mecanismos de fiscalização de atividades que envolvam organismos geneticamente modificados - OGM e seus derivados, cria o Conselho Nacional de Biossegurança - CNBS, reestrutura a Comissão Técnica Nacional de Biossegurança - CTNBio, dispõe sobre a Política Nacional de Biossegurança - PNB, revoga a Lei no 8.974, de 5 de janeiro de 1995, e a Medida Provisória no 2.191-9, de 23 de agosto de 2001, e os arts. 5o, 6o, 7o, 8o, 9o, 10 e 16 da Lei no 10.814, de 15 de dezembro de 2003, e dá outras providências. Diário Oficial da União; 28 mar 2005 [acesso em 13 dez 2012]. Disponível em: http://bit.ly/1mYTENk

Brasil. Decreto ${ }^{\circ}$ 6.323, de 27 de dezembro de 2007. Regulamenta a Lei $\mathrm{n}^{\mathrm{o}} 10.831$, de 23 de dezembro de 2003, que dispõe sobre a agricultura orgânica, e dá outras providências. Diário Oficial da União; 28 dez 2007 [acesso em 6 nov 2012]. Disponível em:

http://www.agricultura.gov.br/arq_editor/file/Desenvolvimento_Sustentavel/Organi cos/Produtos\%20Fitossanit\%C3\%A1rios/Home/decreto_6323_de_27-12-2007.pdf

Brasil Rural Contemporâneo. Brasil Orgânico e Sustentável [internet]. Brasília (DF): Ministério do Desenvolvimento Agrário; 2012 [acesso em 6 jan 2013]. Disponível em:

http://www.mda.gov.br/feira/institucional/brasilorganicoesustentavel 
Bremmers H. An Integrated Analysis of Food Information to Consumers: Problems, Pitfalls, Policies and Progress. In: Proceedings of the $6^{\text {th }}$ International European Forum on System Dynamics and Innovation in Food Networks. 13-17 Feb 2012. Innsbruck-Igls, Austria. International Center for Food Chain and Network Research, University of Bonn, Germany. 2012.

Brownell KD, Warner KE. The perils of ignoring history: Big Tobacco played dirty and millions died. How similar is Big Food? Milbank Q. 2009;87(1):259-94. DOI: 10.1111/j.1468-0009.2009.00555.x.

Brownell KD, Kersh R, Ludwig DS, Post RC, Puhl RM, Schwartz MB, Willett WC. Personal responsibility and obesity: a constructive approach to a controversial issue. Health Aff (Millwood). 2010;29(3):379-87. DOI: 10.1377/hlthaff.2009.0739.

Brownell KD, Koplan JP. Front-of-package nutrition labeling--an abuse of trust by the food industry? N Engl J Med. 2011; 364(25):2373-5. DOI: 10.1056/NEJMp1101033.

Bui M, Kaltcheva VD, Patino A, C. Leventhal RC. Front-of-package product labels: influences of varying nutritional food labels on parental decisions. Journal of Product \& Brand Management. 2013;22(5/6): 352-61.

Cannon G. The Fate of Nations: Food and Nutrition Policy in the New World. London: The Caroline Walker Lecture, 2003.

Caswell JA, Anders SM. Private vs. Third Party vs. Government Labeling. Private vs. Third Party vs. Government Labeling. In The Handbook of the Economics of Food Consumption and Policy, ed. Jayson Lusk, Jutta Rosen, and Jason Shogren, pp. 472-498. Oxford, United Kingdom: Oxford University Press; 2011.

Cavada GS, Paiva FF, Helbig E, Borges LR. Rotulagem nutricional: você sabe o que está comendo? J. Food Technol. 2012;15:84-8.

CFM - Conselho Federal de Medicina. Manual de Publicidade Médica. Resolução $\mathrm{n}^{\mathrm{o}}$ 1.974/11. Brasília (DF): CFM; 2011. Disponível em: http://portal.cfm.org.br/publicidademedica/arquivos/cfm1974_11.pdf

Charaudeau P. Linguagem e discurso: modos de organização. São Paulo: Contexto, 2008 .

Charaudeau P, Maingueneau D. Dicionário de análise do discurso. 3. ed. São Paulo: Contexto, 2012. 
Codex Alimentarius Comission. Food Labelling: Fifth edition. Rome: WHO/ FAO; 2007 [acesso em 15 jan 2013]. Disponível em: $\mathrm{ftp} / / \mathrm{ftp}$.fao.org/docrep/fao/010/a1390e/a1390e00.pdf

Colby SE1, Johnson L, Scheett A, Hoverson B. Nutrition marketing on food labels. J Nutr Educ Behav. 2010 Mar-Apr;42(2):92-8.

Consea - Conselho Nacional de Segurança Alimentar e Nutricional. Promoção da alimentação adequada e saudável [apresentação]. Brasília (DF); 2007. [acesso em 15 set 2012]. Disponível em:

http://www4.planalto.gov.br/consea/documentos/alimenatacao-adequada-esaudavel/apresentacao-alimentacao-adequada-e-saudavel

Costa TEMM, Marin VA. Rotulagem de alimentos que contém Organismos Geneticamente Modificados: políticas internacionais e Legislação no Brasil. Ciênc. saúde coletiva. 2011;16(8):3571-82.

Crescitelli E, Shimp TA. Comunicação de marketing: integrando propaganda, promoção e outras formas de divulgação. São Paulo: Cengage Learning, 2012.

Daily mail. Grocers sue Vermont over GMO food label law. Daily Mail Online; 12 jun 2014 Disponível em: http://dailym.ai/1tSCFSk

Dalmeny K. How can improved food labelling contribute to a sustainable food system? London: Sustain; mar 2007 [acesso em 12 set 2012]. Disponível em: http://www.sustainweb.org/publications/?id=231

Daugbjerg C, Smed S, Andersen LM, Schvartzman Y. Improving eco-labelling as an environmental policy instrument: knowledge, trust and organic consumption. J Environ Policy Plan. Epub 2014 Feb 10 [acesso em 12 mar 2014]. Disponível em: http://www.tandfonline.com/doi/pdf/10.1080/1523908X.2013.879038.

DOI:10.1080/1523908X.2013.879038.

Dendler L. Sustainability meta labelling: an effective measure to facilitate more sustainable consumption and production? J Clean Prod. 2013;63:74-83. DOI:10.1016/j.jclepro.2013.04.037.

Dorfman L, Cheyne A, Friedman LC, Wadud A, Gottlieb M. Soda and Tobacco Industry Corporate Social Responsibility Campaigns: How Do They Compare? PLoS Med. 2012 ; 9(6): e1001241.

Downs J, Loewenstein G, Wisdom J. The Psychology of Food Consumption: Strategies for Promoting Healthier Food Choices. American Economic Review: Papers \& Proceedings. 2009; 99(2):1-10. 
Drichoutis AC, Lazaridis P. Nutrition knowledge and consumer use of nutritional food labels. European Review of Agricultural Economics.2005;32 (1): 93-118.

Ecolabel Index [internet]. Vancouver: Big Room Inc; 2013 [acesso em $25 \mathrm{dez}$ 2012]. Disponível em: http://www.ecolabelindex.com/ecolabels/?st=category,food

Ellis S, Glanville NT. Trans fat information on food labels: consumer use and interpretation. Can J Diet Pract Res. 2010 Spring;71(1):6-10.

Emrich TE, Qi Y, Mendoza JE, Lou W, Cohen JE, L'Abbé MR. Consumer perceptions of the nutrition facts table and front-of-pack nutrition rating systems. Appl Physiol Nutr Metab. 2014;39(4):417-24. DOI:10.1139/apnm-2013-0304.

Engels SV, Hansmann R, Scholz RW. Toward a Sustainability Label for Food Products: An Analysis of Experts' and Consumers' Acceptance. Ecology of Food and Nutrition. 2010; 49(1): 30-60. DOI: 10.1080/03670240903433154

EunSeok Cha, Kim KH, Lerner HM, Dawkins CR, Bello MK, Umpierrez G, Dunbar SB. Health literacy, self-efficacy, food label use, and diet in young adults. American Journal of Health Behavior. 2014;38(3):331-9.

FAO - Food and Agriculture Organization of the United Nations. Sustainable diets and biodiversity: Directions and solutions for policy, research and action. Rome: FAO; 2012 [acesso em 27 ago 2012]. Disponível em: http://www.fao.org/docrep/016/i3004e/i3004e.pdf

FAO - Food and Agriculture Organization of the United Nations. Food labeling/ Social labeling [internet]. Rome: FAO, 2013 [atualizado em 3 jul 2012; acesso em 24/12/2012] Disponível em: http://www.fao.org/ag/humannutrition/foodlabel@172032/en/

FASE - Federação de Órgãos para Assistência Social e Educacional. Transgênicos? É hora de restaurar o Princípio da Precaução. Mercado Ético, 22 mar 2012 [acesso em 23 dez 2012]. Disponível em: http://bit.ly/1qLwauU

Fernandes LB, Machado SS, Vieira DAP. AVALIAÇÃO QUALITATIVA DO HÁBITO DE LEITURA E ENTENDIMENTO DOS RÓTULOS. IV Seminário de Iniciação Científica do Instituto Federal de Educação, Ciência e Tecnologia de Goiás/IFG. 16- 17 set 2010; Inhumas, GO. IFG / Campus Inhumas, 2010.

Ferreira AB, Lanfer-Marquez UM. Legislação brasileira referente à rotulagem nutricional de alimentos. Rev. Nutr. 2007;20(1):83-93.

Fiorin JL. Elementos de análise do discurso. São Paulo: Contexto/ Edusp. 1989. 
Fischer LM, Sutherland LA, Kaley LA, Fox TA, Hasler CM, Nobel J, Kantor MA, Blumberg J. Development and implementation of the guiding stars nutrition guidance program. Am J Health Promot. 2011;26(2):e55-63. DOI: 10.4278/ajhp.100709-QUAL-238.

Fonseca AB, Souza TSN, Frozi DS, Pereira RA. Modernidade alimentar e consumo de alimentos: contribuições sócio-antropológicas para a pesquisa em nutrição. Ciência \& Saúde Coletiva. 2011;16(9):3853-62.

Furnival AC, Pinheiro SM. O público e a compreensão da informação nos rótulos de alimentos: o caso dos transgênicos. Revista Digital de Biblioteconomia e Ciência da Informação. 2009; 7 (1): 1-19. ISSN: 1678765X.http://143.106.108.14/seer/ojs/index.php/rbci/article/view/411/275

Furst T, Connors M, Sobal J, Bisogni C, Falk LW. Food classifications: Levels and categories. Ecology of Food and Nutrition. 2000;39(5):331-55.

Garcia RWD. Representações sociais da alimentação e saúde e suas repercussões no comportamento alimentar. Rev. Saúde Coletiva. 1997;7(2):51-68.

Gaschler R, Mata J, Störmer VS, Kühnel A, Bilalic'M. Change detection for new food labels. Food Quality and Preference. 2010;21:140-7.

Getz C, Shreck A. What organic and Fair Trade labels do not tell us: towards a place-based understanding of certification. International Journal of Consumer Studies. 2006; 30(5):490-501.

Glanz K. Measuring food environments: a historical perspective. Am J Prev Med. 2009;36(4 Suppl):S93-8. DOI: 10.1016/j.amepre.2009.01.010.

Golan E, Kuchler F, Mitchell L. Economics of Food Labeling. Journal of Consumer Policy. 2001; 24: 117-84.

GoodGuide.com [internet] Berkeley: GoodGuide, Inc; 2011 [acesso em 10 jan 2013]. Disponível em: http://www.goodguide.com/

Grabenhorst F, Schulte FP, Maderwald S, Brand M. Food labels promote healthy choices by a decision bias in the amygdala. NeuroImage. 2013;74:152-63.

Gracia A, Barreiro-Hurlé J, López- Galán B. Are Local and Organic Claims Complements or Substitutes? A Consumer Preferences Study for Eggs. Journal of Agricultural Economics. 2014;65(1):49-67.

Gregolin MRV. A análise do discurso - conceitos e aplicações. Alfa.1995;39:13-21 
Grunert KG, Wills JM, Fernández-Celemín L. Nutrition knowledge, and use and understanding of nutrition information on food labels among consumers in the UK. Appetite. 2010 Oct;55(2):177-89.

Grunert KG, Scholderer J, Rogeaux M. Determinants of consumer understanding of health claims. Appetite. 2011 Apr;56(2):269-77.

Gunther A. What Do Food Labels Like 'Cage Free' Hide From You? Huffington Post, 2 jan 2013. Disponível em: http://www.huffingtonpost.com/zester-daily/foodlabels_b_2385355.html

Harris JL, Brownell KD, Bargh JA. The Food Marketing Defense Model: Integrating Psychological Research to Protect Youth and Inform Public Policy. Soc Issues Policy Rev. 2009;3(1):211-71.

Harris JL, Thompson JM, Schwartz MB, Brownell KD. Nutrition-related claims on children's cereals: what do they mean to parents and do they influence willingness to buy? Public Health Nutrition. 2011;14(12): 2207-12.

Hawkes C. Informação Nutricional e Alegações de Saúde: o cenário global das regulamentações. Brasília (DF): Organização Pan-Americana da Saúde/ Agência Nacional de Vigilância Sanitária; 2006 [acesso em 14 out 2012]. Disponível em: http://bit.ly/1mlIePm

Hawley KL, Roberto CA, Bragg MA, Liu PJ, Schwartz MB, Brownell KD. The science of front-of-package food labels. Public Health Nutr. 2012; 22:1-10.

Hemmerling S, Obermowe T, Canavari M, Sidali KL, Stolz H, Spiller A. Organic food labels as a signal of sensory quality - insights from a cross-cultural consumer survey. Org. Agr. 2013;3:57-69.

Hersey JC, Wohlgenant KC, Arsenault JE, Kosa KM, Muth MK. Effects of frontof-package and shelf nutrition labeling systems on consumers. Nutrition Reviews. 2013; 71(1):1-14. DOI:10.1111/nure.12000

Hieke S, Taylor CR. A Critical Review of the Literature on Nutritional Labeling. The Journal of Consumer Affairs. 2012;46(1): 120-56. DOI: 10.1111/j.17456606.2011.01219.x

Hoefkens C, Verbeke W, Van Camp J. European consumers' perceived importance of qualifying and disqualifying nutrients in food choices. Food Quality and Preference. 2011;22:550-8. 
Hoek J, Roling N, Holdsworth D. Ethical claims and labelling: An analysis of consumers' beliefs and choice behaviours. Journal of Marketing Management. 2012; iFirst: 1-21. DOI: 10.1080/0267257X.2012.715430

Holzer B. Political consumerism between individual choice and collective action: social movements, role mobilization and signalling. International Journal of Consumer Studies. 2006;30(5):405-15.DOI: 10.1111/j.1470-6431.2006.00538.x

Hortifruti. A origem das nossas estrelas [internet]. Vitória: Hortifruti, Blog da Maçã; 9 nov 2012 [acesso em 15 jan 2013]. Disponível em: http://www.hortifruti.com.br/blog/2012/11/a-origem-das-nossas-estrelas/

Howard PH, Allen P. Beyond organic: consumer interest in new labelling schemes in the Central Coast of California. International Journal of Consumer Studies. 2006; 30(5):439-51

Hornick BA, Childs NM, Edge MS, Kapsak WR, Dooher C, White C. Is it time to rethink nutrition communications? A 5-year retrospective of Americans' attitudes toward food, nutrition, and health. Journal of the Academy of Nutrition and Dietetics. 2013;113 (1): 14-23.

Idec - Instituto Brasileiro de Defesa do Consumidor. Garantia que não convence. Revista do Idec n ${ }^{\circ} 77$, maio 2004; p.16-8. São Paulo: Instituto Brasileiro de Defesa do Consumidor; 2004.

Idec - Instituto Brasileiro de Defesa do Consumidor. Saiba o que são os alimentos transgênicos e quais os seus riscos [internet]. São Paulo: Idec; 1996-2013 [acesso em 6 jan 2013]. Disponível em: http://bit.ly/1oO56sp

Idec - Instituto Brasileiro de Defesa do Consumidor. Sinal amarelo para o semáforo nutricional. Revista do Idec no 172, dez 2012; p.30-3. São Paulo: Instituto Brasileiro de Defesa do Consumidor; 2012.

IDEC. Rótulo nutricional ou bicho de sete cabeças? Revista do Idec, agosto 2013, p. 14-7.

IOM - Institute of Medicine. Front-of-Package Nutrition Rating Systems and Symbols: Phase I Report. Washington, DC: National Academies Press; 2010 [acesso em 17 set 2012]. Disponível em: http://www.nap.edu/catalog.php?record_id=12957

Iraldo F, Testa F, Bartolozzi I. An application of Life Cycle Assessment (LCA) as a green marketing tool for agricultural products: the case of extra-virgin olive oil in 
Val di Cornia, Italy. Journal of Environmental Planning and Management. 2013. DOI:10.1080/09640568.2012.735991

Jasti S, Kovacs S. Use of trans fat information on food labels and its determinants in a multiethnic college student population. J Nutr Educ Behav. 2010 SepOct;42(5):307-14.

Johnston J. The citizen-consumer hybrid: ideological tensions and the case of Whole Foods Market. Theor Soc. 2008; 37:229-70. DOI 10.1007/s11186-0079058-5

Kempen E, Bosman M, Bouwer C, Klein R, van der Merwe D. An exploration of the influence of food labels on South African consumers' purchasing behavior. International Journal of Consumer Studies. 2011; 35(1):69-78.

Kessler DA, Mande JR, Scarbrough FE, Schapiro R, Feiden K. Developing the "Nutrition Facts" food label. Harvard Health Policy Review.2003;4:13-24.

Kim S-Y. Nayga, Jr. RM, Capps Jr. O. The effect of food label use on nutrient intakes: an endogenous switching regression analysis. Journal of Agricultural and Resource Economics. 2000;25(1):215-31

Klintman M. Ambiguous framings of political consumerism: means or end, product or process orientation? International Journal of Consumer Studies. 2006; 30 (5):427-38.

Koenigstorfer J, Wa sowicz-Kirylo G, Stys'ko-Kunkowska M, Groeppel-Klein A. Behavioural effects of directive cues on front-of-package nutrition information: the combination matters! Public Health Nutrition. 2013;FirstView Article:1-7.

Lairon D. Biodiversity and sustainable nutrition with a food-based approach. In: Burlingame B, Dernini S (editores). Sustainable diets and biodiversity - Directions and solutions for policy, research and action. Food and Agriculture Organization of the United Nations. Roma, 2012, p. 30.

Lima F. Em fogo alto. Página22 n $n^{0} 70$, dez 2012; p. 38-42. São Paulo: Fundação Getúlio Vargas; 2012a [acesso em 15 dez 2012]. Disponível em: http://pagina22.com.br/index.php/2012/12/em-fogo-alto/

Lima FCC, Miklasevicius B. Análise semiótica da marca Mãe Terra: o potencial comunicativo de suas embalagens. SIGNOS DO CONSUMO. 2012b;4:237-52.

Lin CT, Lee JY, Yen ST. Do dietary intakes affect search for nutrient information on food labels? Soc Sci Med. 2004;59(9):1955-67. 
Lipovetsky G. A felicidade paradoxal: ensaio sobre a sociedade de hiperconsumo. São Paulo: Companhia das Letras, 2007.

Llano Linares NL, Trindade E. Processos de movimentos de significados simbólicos no consumo alimentar. Pensam. Real. 2011;26:46-64

Lobstein T, Davies S. Defining and labelling 'healthy' and 'unhealthy' food. Public Health Nutrition. 2008; 12(3):331-40. doi:10.1017/S1368980008002541

Lowe B, Souza-Monteiro DM, Fraser I. Nutritional labelling information: Utilisation of new technologies. Journal of Marketing Management. 2013;29(1112): $1337-66$

Lucchese-Cheung T, Batalha MO, Lambert JL. Comportamentos do consumidor de alimentos: tipologia e representação da comida. Agroalimentaria. 2012;18(35):11529.

Ludwig DS, Nestle M. Can the food industry play a constructive role in the obesity epidemic? JAMA. 2008;300(15):1808-11.

Lwin MO, Morrin M, Tang SW, Low JY, Nguyen T, Lee WX. Stanley W. H. Tang, Jin Yong Low, Thu Nguyen, Wei Xun Lee. See the Seal? Understanding Restrained Eaters' Responses to Nutritional Messages on Food Packaging. Health Communication. 2013;1-17.

Macedo AR, Araújo N. Meio Ambiente deve criar subcomissão para avaliar transgênicos no Brasil. Brasília (DF): Agência Câmara Notícias; 8 nov 112012 [acesso em 2013 jan 6]. Disponível em: http://bit.ly/1oO56sp

MacRae R, Szabo M, Anderson K, Louden F, Trillo S. Empowering the CitizenConsumer: Re-Regulating Consumer Information to Support the Transition to Sustainable and Health Promoting Food Systems in Canada. Sustainability. 2012; 4, 2146-75. DOI:10.3390/su4092146

Maingueneau D. Novas tendências em análise do discurso. Campinas: Pontes, 1989.

Maingueneau D. Novas tendências em análise do discurso. 2. ed. Campinas: Pontes, 1993.

Maingueneau D. Análise de textos de comunicação. 2. ed. São Paulo: Cortez, 2002.

MAPA - Ministério da Agricultura, Pecuária e Abastecimento. Instrução Normativa 13, de 30 de novembro de 2004. Aprova o regulamento técnico sobre 
aditivos para produtos destinados à alimentação animal, segundo as boas práticas de fabricação, contendo os procedimentos sobre avaliação da segurança de uso, registro e comercialização, constante dos anexos desta Instrução Normativa. Diário Oficial da União; 1 dez 2004 [acesso em 8 nov 2012]. Disponível em: http://bit.ly/1yygobg

MAPA - Ministério da Agricultura, Pecuária e Abastecimento. Instrução Normativa $\mathrm{n}^{\circ} 22$, de 24 de novembro de 2005. Aprova o Regulamento Técnico para Rotulagem de Produto de Origem Animal embalado. Diário Oficial da União; 25 nov 2005 [acesso em 8 nov 2012]. Disponível em: http://www2.rio.rj.gov.br/vigilanciasanitaria/legislacao/instrucao_normativa_22_20 05.pdf

MAPA - Ministério da Agricultura, Pecuária e Abastecimento. Orgânicos [internet]. Brasília (DF): MAPA; [s.d.] [citado 2013 jan 6]. Disponível em: http://www.agricultura.gov.br/desenvolvimento-sustentavel/organicos

Marins BR, Jacob SC, Peres F. Avaliação qualitativa do hábito de leitura e entendimento: recepção das informações de produtos alimentícios. Ciênc. Tecnol. Aliment. 2008; 28(3): 579-85.

Martín-Barbero J. Dos meios às mediações: comunicação, cultura e hegemonia. Rio de Janeiro: Editora UFR, 2009.

Mazis MB, Raymond MA. Consumer Perceptions of Health Claims in Advertisements and on Food Labels. Journal of Consumer Affairs. 1997;31(1):1026.

McCracken G. Cultura e consumo. Rio de Janeiro: Mauad; 2003.

McCracken G. Cultura e consumo: uma explicação teórica da estrutura e do movimento do significado cultural dos bens de consumo. Rev. adm. empres. 2007; 47(1): 99-115.

McKinnon RA, Reedy J, Morrissette MA, Lytle LA, Yaroch AL. Measures of the food environment: a compilation of the literature, 1990-2007. Am J Prev Med. 2009;36(4 Suppl):S124-33. DOI: 10.1016/j.amepre.2009.01.012.

MDA - Ministério do Desenvolvimento Agrário. Portaria $n^{0} 7$, de 13 de janeiro de 2012. Institui o selo de identificação da participação da agricultura familiar e dispõe sobre os critérios e procedimentos relativos à permissão, manutenção, cancelamento de uso. Brasília (DF); 2012 [acesso em 10 out 2012]. Disponível em: http://www.seagri.ba.gov.br/selo_suaf/selo_portaria_n07_13_janeiro_2012.pdf 
MDA - Ministério do Desenvolvimento Agrário. Secretaria da Agricultura Familiar/ Programas [internet]. Brasília (DF): MDA; [s.d.] [acesso em 6 jan 2013]. Disponível em: http://www.mda.gov.br/portal/saf/programas/SIPAF

Mercosul. Resolução $n^{0} 47$ de 2003. Regulamento Técnico de Porções de Alimentos Embalados. LII GMC. Montevidéu, 10 dez 2003. Disponível em: http://www.mercosur.int/msweb/Normas/normas_web/Resoluciones/PT/Res_047_0 03_\%20RTM\%20Por\%C3\%A7\%C3\%B5es\%20Alim\%20Emb\%20Rot $\% 20$ Nutric_ Ata\%2004_03\%20\%20\%20\%20T.PDF

Mestriner F. Design de embalagem - curso básico. São Paulo: Makron Books, 2001 .

Miller LMS, Cassady DL. Making healthy food choices using nutrition facts panels. The roles of knowledge, motivation, dietary modifications goals, and age. Appetite. 2012;59:129-39.

MJ - Ministério da Justiça. Portaria $n^{\circ} 2658$, de 22 de dezembro de 2003. Define o símbolo de que trata o art. $2^{\circ}, \S 1^{\circ}$, do Decreto 4.680, de 24 de abril de 2003, na forma do anexo à presente portaria. Brasília (DF); 2003 [acesso em 3 nov 2012]. Disponível em: http://portal.anvisa.gov.br/wps/wcm/connect/1e3d43804ac0319e9644bfa337abae9d /Portaria_2685_de_22_de_dezembro_de_2003.pdf?MOD=AJPERES

MS - Ministério da Saúde. As cartas da promoção da saúde. Brasília (DF); Ministério da Saúde; 2002 [acesso em 20 dez 2012]. Disponível em: http://dtr2001.saude.gov.br/editora/produtos/livros/pdf/02_1221_M.pdf

MS - Ministério da Saúde. Política Nacional de Promoção da Saúde. Brasília (DF): Ministério da Saúde; 2006 [acesso em 7 dez 2012]. Disponível em:

http://portal.saude.gov.br/portal/arquivos/pdf/pactovolume7.pdf

MS - Ministério da Saúde. Guia Alimentar para a População Brasileira:

promovendo a alimentação saudável. Brasília (DF): Ministério da Saúde; 2008 [acesso em 16 ago 2012]. Disponível em:

http://bvsms.saude.gov.br/bvs/publicacoes/guia_alimentar_populacao_brasileira.pdf

MS - Ministério da Saúde. Conselho Nacional de Saúde. Resolução CNS no 408, de 11 de dezembro de 2008. Diário Oficial da União; 9 mar 2009 [acesso $18 \mathrm{dez}$ 2012]. Disponível em:

http://conselho.saude.gov.br/ultimas_noticias/2010/img/211_ro/Reso408.pdf

MS - Ministério da Saúde. Política Nacional de Alimentação e Nutrição. Brasília (DF): Ministério da Saúde; 2012 [acesso em 18 ago 2012]. Disponível em: 
http://bvsms.saude.gov.br/bvs/publicacoes/politica_nacional_alimentacao_nutricao. pdf

MS - Ministério da Saúde. Consulta Pública nº 04. Guia Alimentar para a População Brasileira. Brasília (DF): Ministério da Saúde; 2014 [acesso em 12 fev 2014]. Disponível em: http://200.214.130.94/CONSULTAPUBLICA/INDEX.PHP?MODULO=DISPLAY $\&$ SUB $=$ DSP_CONSULTA

Mismetti D. Selo de aprovação médica em produtos pode voltar a valer. Folha de S. Paulo, 15 fev 2012 [acesso em 9 jan 2013]. Disponível em: http://www1.folha.uol.com.br/equilibrioesaude/1049008-selo-de-aprovacaomedica-em-produtos-pode-voltar-a-valer.shtml

Monteiro CA. Nutrition and health. The issue is not food, nor nutrients, so much as processing. Invited commentary. Public Health Nutrition. 2009;12: 729-31.

Monteiro CA, Levy RB, Claro RM, Castro IRR, Cannon,G. A new classification of foods based on the extent and purpose of their processing. Cad.Saúde Pública. 2010; 26:2039-49.

Monteiro CA, Cannon G, Levy RB, Claro RM, Moubarac J-C. The Food System. Ultra-processing. The big issue for nutrition, disease, health, well-being. [Commentary].World Nutrition December 2012a, 3, 12, 527-569

Monteiro CA, Cannon G. The Impact of Transnational "Big Food" Companies on the South: A View from Brazil. PLoS Med. 2012b; 9(7): e1001252. DOI:10.1371/journal.pmed.1001252

Monteiro RA, Coutinho JG, Recine E. Consulta aos rótulos de alimentos e bebidas por frequentadores de supermercados em Brasília, Brasil. Rev Panam Salud Publica. 2005;18(3): 172-7.

Moorman C, Diehl K, Brinberg D, Kidwell B. Subjective Knowledge, Search Locations, and Consumer Choice. Journal of Consumer Research. 2004; 31: 67380 .

Moss M. Salt, Sugar, Fat: how the food giants hooked us. New York: Random House, 2013.

Nayga Jr. RM. On Consumers' Perception About the Reliability of Nutrient Content Claims on Food Labels, Journal of International Food \& Agribusiness Marketing. 2000; 11(1): 43-55. 
Nestle M. Food politics. Berkeley: University of California Press, 2003.

Nestle M. Food industry thinks name change will disguise bad labeling scheme [internet]. New York: Food Politics Blog; 27 set 2011. [acesso em 8 jan 2013] Disponível em: http://bit.ly/1r7cT9t

Nestle M. What to do about front-of-package food labels? [internet] New York: Food Politics Blog; 24 out 2012. [citado 2013 jan 8] Disponível em: http://www.foodpolitics.com/2012/10/what-to-do-about-front-of-package-foodlabels/

News21. Rethink the food label [internet]. Berkeley: University of California; 2011 [acesso em 9 jan 2013]. Disponível em: http://berkeley.news21.com/foodlabel/

Nørgaard MK, Brunsø K. Families' use of nutritional information on food labels. Food Quality and Preference.2009;20:597-606.

Nurliyana G, Norazmir MN, Khairil Anuar MI. Knowledge, Attitude and Practices of University Students Regarding the Use of Nutritional Information and Food Labels. Asian Journal of Clinical Nutrition. 2011; 3(3):79-91.

NuVal.com [internet]. Derby: NuVal LLC; 2013 [acesso em 10 jan 2012]. Disponível em: http://www.nuval.com

OMS - Organização Mundial de Saúde. Projeto do décimo primeiro ProgramaGeral de Trabalho para 2006-2015: resumo [internet]. [S.1.]; 2005 [acesso em 30 jan 2013]. (RC/2005/2). Disponível em: http://bit.ly/1nQcHKF

Orlandi EP. As formas do silêncio: no movimento dos sentidos. 6. ed. Campinas: Editora da Unicamp, 2007.

Orlandi EP. Análise de discurso: princípios \& procedimentos. 10. ed. Campinas: Pontes; 2012a.

Orlandi EP. Discurso em análise: sujeito, sentido e ideologia. Campinas: Pontes Editores, 2012b.

O'Rourke D. Market Movements: Nongovernmental organization Strategies to Influence Global Production and Consumption. Journal of Industrial Ecology. 2005; 9(1-2): 115-28.

Parker-Pope T. Designing a Better Food Label [internet]. New York: The New York Times; 28 jul 2011. Blog Well [acesso em 10 jan 2013]. Disponível em: http://well.blogs.nytimes.com/2011/07/28/designing-a-better-food-label/ 
Parks J. The effects of food labeling and dietary guidance on nutrition in the United States. In: Selected Paper prepared for presentation at the Agricultural \& Applied Economics Association's 2013 AAEA \& CAES Joint Annual Meeting. Washington, DC, United States. U.S. Food and Drug Administration. Center for Food Safety and Applied Nutrition, 2013.

Pêcheux M. O discurso: estrutura ou acontecimento. 2.ed. Campinas: Pontes, 1997.

Pelicioni, Maria Cecília Focesi. A educação e a comunicação para a promoção da saúde. In: Saúde Pública: bases conceituais. 2.ed. Rio de Janeiro: Atheneu, 2013.

Perez C. Mascotes: semiótica da vida imaginária. São Paulo: Cengage Learning, 2011.

Philippi ST, Latterza AR, Cruz ATR, Ribeiro LC. Pirâmide alimentar adaptada: guia para escolha dos alimentos. Rev. Nutr. 1999;12:65-80.

Pollan M. O dilema do onívoro: uma história natural de quatro refeições. Rio de Janeiro: Intrínseca; 2007.

Pollan M. Em defesa da comida. Rio de Janeiro: Intrínseca; 2008.

Portilho F, Castañeda M, Castro IRR. A alimentação no contexto contemporâneo: consumo, ação política e sustentabilidade. Ciência \& Saúde Coletiva. 2011; 16(1):99-106.

POULIN JP. Sociologias da alimentação: os comedores e o espaço social alimentar. Florianópolis: UFSC, 2006.

Prinsloo N, van der Merwe D, Bosman M, Erasmus A. A critical review of the significance of food labeling during consumer decision making. Journal of Family Ecology and Consumer Sciences. 2012; 40:83-98.

Rahkovsky I, Lin BH, Jordan Lin CTJ, Lee JY. Effects of the Guiding Stars Program on purchases of ready-to-eat cereals with different nutritional attributes. Food Policy. 2013;43:100-7.

Reczkova L, Sulaiman J, Bahari Z. Some issues of consumer preferences for ecolabeled fish to promote sustainable marine capture fisheries in peninsular Malaysia. Procedia - Social and Behavioral Sciences. 2013; 91:497-504.

Ribeiro IG, Marin VA. A falta de informação sobre os Organismos Geneticamente Modificados no Brasil. Ciênc. saúde coletiva. 2012;17:359-68. 
Roberto CA, Bragg MA, Livingston KA, Harris JL, Thompson JM, Seamans MJ, Brownell, KD. Choosing front-of-package food labelling nutritional criteria: how smart were 'Smart Choices'? Public Health Nutrition. 2011; 15(2), 262-7. DOI: $10.1017 / \mathrm{S} 1368980011000826$

Roberto CA, Bragg MA, Seamans MJ, Mechulan RL, Novak N, Brownell KD. Evaluation of Consumer Understanding of Different Front-of-Package Nutrition Labels, 2010-2011. Prev Chronic Dis. 2012;9:120015. DOI: 10.5888/pcd9.120015

Robin MM. The world according to Monsanto [filme]. National Film Board of Canada; 2008 [acesso em16 jan 2013]. Disponível em: http://www.youtube.com/watch?v=-WxpjH7XiGE

Roodenburg AJC, Popkin BM, Seidell JC. Development of international criteria for a front of package food labelling system: the International Choices Programme. European Journal of Clinical Nutrition. 2011; 1-11. DOI: doi:10.1038/ejen.2011.101

Rothman RL, Housam R. Weiss H. Davis D, Gregory, R. Gebretsadik T, Shintani A, Elasy TA. Patient understanding of food labels: The role of literacy and numeracy. American Journal of Preventive Medicine. 2006;31(5):391-8.

Rousseau S, Vranken L. Green market expansion by reducing information asymmetries: Evidence for labeled organic food products. Food Policy. 2013; 40:31-43.

Saha S, R Vemula S, Mendu VV, Gavaravarapu SM. Knowledge and practices of using food label information among adolescents attending schools in Kolkata, India. J Nutr Educ Behav. 2013 Nov-Dec;45(6):773-9.

Salomon M. Indústria resiste à rotulagem de transgênico. Folha de S. Paulo, 10 mar 2005; Caderno Mercado [acesso em 31 jan 2014]. Disponível em: http://www1.folha.uol.com.br/fsp/dinheiro/fi1003200502.htm

Sangkumchalianga P, Huang WC. Consumers' Perceptions and Attitudes of Organic Food Products in Northern Thailand. International Food and Agribusiness Management Review. 2012; 15 (1): 87-102.

Santaella L. A teoria geral dos signos: como as linguagens significam as coisas. São Paulo: Pioneira, 2000.

Santaella L. Semiótica Aplicada. São Paulo: Thomson, 2007. 
Savoie N, Barlow Gale K, Harvey KL, Binnie MA, Pasut L. Consumer perceptions of front-of-package labelling systems and healthiness of foods. Can J Public Health. 2013;104(5):e359-63.

SBC - Sociedade Brasileira de Cardiologia. Selo de Aprovação da SBC [internet]. São Paulo: SBC; 1996-2010 [acesso em 2013 jan 9]. Disponível em: http://prevencao.cardiol.br/selo/o-que-selo.asp

Schroeter C, Anders SM. Nutrition Label Usage Diet Health Behavior and Information Uncertainty. Agricultural and Applied Economics Association. Annual Meeting, August 4-6, 2013, Washington, D.C, 2013.

Schubert L, Gallegos D, Foley W, Harrison C. Re-imagining the 'social' in the nutrition sciences. Public Health Nutr. 2012;15(2):352-9. DOI: 10.1017/S1368980011001297.

Scrinis G. Sorry, Marge. Meanjin. 2002; 61(4):108-16

Scrinis G. Labels: an unhealthy trend. The Age, Op-Ed; 30 dez 2005 [acesso em 8 dez 2012]. Disponível em: http://www.gyorgyscrinis.com/GS-Labels.pdf

Scrinis G. Nutricionism: the science and politics of dietary advice. New York: Columbia University Press, 2013.

SDH - Secretaria de Direitos Humanos. Resolução No- 163, de 13 de março de 2014. Dispõe sobre a abusividade do direcionamento de publicidade e de comunicação mercadológica à criança e ao adolescente. Diário Oficial da União; 4 abril 2014 [acesso em 18 mai 2014]. Disponível em: http://www.jusbrasil.com.br/diarios/68613125/dou-secao-1-04-04-2014-pg-4.

Sharf M, Sela R, Zentner G, Shoob H, Shai I, Stein-Zamir C. Figuring out food labels. Young adults' understanding of nutritional information presented on food labels is inadequate. Appetite. 2012;58(2):531-4

Shekhar SK, Raveendran PT. Does nutritional labeling increase healthy eating fallacy? An exploration into young Indian's purchase behavior. Management Science Letters. 2013;3: 2945-56.

Spaniolo LM, Howard P. Consumer preferences for alternative eco-labels: A qualitative analysis of natural food store and food co-op shoppers' motivations. Appetite. 2011;56(2):545. DOI: 10.1016/j.appet.2010.11.264

Sobal J, Khan LK, Bisogni C. A conceptual model of the food and nutrition system. Soc. Sci. Med. 1998; 47 (7): 53-63. 
Sonnenberg L, Gelsomin E, Levy DE, Riis J, Barraclough S, Thorndike AN. A traffic light food labeling intervention increases consumer awareness of health and healthy choices at the point-of-purchase. Prev Med. 2013;57(4):253-7.

Souza SMFC, Lima Miranda HF, Cavalcanti FID. Utilização da informação nutricional de rótulos por consumidores de Natal, Brasil. Rev Panam Salud Publica. 2011;29(5):337-43.

Stran KA, Knol LL. Determinants of Food Label Use Differ by Sex. J Acad Nutr Diet. 2013;113:673-9.

Stuckler D, Nestle M. Big Food, Food Systems, and Global Health. PLoS Med. 2012 9(6): e1001242. doi:10.1371/journal.pmed.1001242

Sustain, 2007. Discussion paper from Sustain: Pictorial representations for sustainability scoring. London: Sustain; jun 2007 [acesso em 1 out 2012]. Disponível em: http://www.sustainweb.org/publications/?id=228

Svederberg E, Wendin K. Swedish consumers' cognitive approaches to nutrition claims and health claims. Food Nutr Res. 2011 Mar 23;55.

Tang E, Fryxell GE, Chow CSF. Visual and verbal communication in the design of eco-label for green consumer products. J Int Consum Mark. 2004;16(4):85-105. DOI:10.1300/J046v16n04_05.

Tarabella A, Lelia Voinea L. Advantages and limitations of the Front-Of-Package (FOP) labeling systems in guiding the consumers' healthy food choice. Amfiteatru Economic. 2013; 15(33): 198-209.

Tavares F, Irving MA. Natureza S.A.: O consumo verde na lógica do Ecopoder. São Paulo: Rima, 2009.

Taylor CL, Wilkening VL. How the nutrition food label was developed, Part 1: the Nutrition Facts panel. J Am Diet Assoc. 2008a;108(3):437-42. DOI: 10.1016/j.jada.2007.12.010.

Taylor CL, Wilkening VL. How the nutrition food label was developed, Part 2: the purpose and promise of nutrition claims. J Am Diet Assoc. 2008b;108(4):618-23. DOI: 10.1016/j.jada.2008.01.009.

Temple NJ, Fraser J. Food labels: A critical assessment. Nutrition. 2014;30:257-60. 
The Economist. Food for thought. Special report: obesity; Food companies; $15 \mathrm{dez}$ 2012. Disponível em: http://www.economist.com/news/special-report/21568064food-companies-play-ambivalent-part-fight-against-flab-food-thought

The George Institute. Foodswitch: Helping you make healthier food choices [internet]. Sydney: University of Sydney; 2013 [acesso em 8 jan 2013]. Disponível em: http://www.georgeinstitute.org.au/foodswitch

Trindade E. Enunciação publicitária e recepção: problemas, considerações e diretrizes. In: XXX Congresso Brasileiro de Ciências da Comunicação; 29 ago-2 set 2007. Santos, BR. [acesso em 27 jan 2014] Disponível em: http://www.intercom.org.br/papers/nacionais/2007/resumos/R0140-1.pdf

Trindade E. Da etnografia à produção de sentido da recepção publicitária e das práticas de consumo na vida social. Animus-Revista Interamericana de Comunicação midiática. 2009a; 15:1-15.

Trindade E. Semiótica e publicidade de alimentos: uma revisão teórica e aplicada. Pensam. Real. 2009b;24:29-46.

Trindade E. Um olhar exploratório sobre o consumo e a midiatização das marcas de alimentos nas vidas de algumas famílias. Matrizes. 2012;1:77-96.

Tzilivakis J, Green A, Warner D, McGeevor K, Lewis K. A framework for practical and effective eco-labelling of food products. Sustainability Accounting, Management and Policy Journal. 2012; 3 (1): 50-73. DOI $10.1108 / 20408021211223552$

Vasconcelos Y, Correa E, Alves L, Santos P. Quais são os principais selos ecológicos no mercado? Revista Vida Simples, set 2008 [acessado em $21 \mathrm{dez}$ 2012]. Disponível em:

http://planetasustentavel.abril.com.br/noticia/desenvolvimento/conteudo_298573.sh tml

Vidgen HA, Gallegos D. Defining food literacy and its components. Appetite. 2014; pii: S0195-6663(14)00018-X. doi: 10.1016/j.appet.2014.01.010.

Wahlqvist M, Kouris-Blazos A. Food-based dietary guidelines (FBDGs): traditional cuisines, modern foods and the environment. The Ind. J. Nutr. Dietet. 1999;36:398-404.

Wezemael LV, Caputo V, Nayga Jr. RM, Chryssochoidis G, Verbeke W. European consumer preferences for beef with nutrition and health claims: A multi-country investigation using discrete choice experiments. Food Policy. 2014; 44:167-76. 
Wilkins JL. Eating right here: Moving from consumer to food citizen. Agriculture and Human Values.2005; 22: 269-273. DOI 10.1007/s10460-005-6042-4

Wills JM, Schmidt DB, Pillo-Blocka F, Cairns G. Exploring global consumer attitudes toward nutrition information on food labels. Nutr Rev. 2009 May;67 Suppl 1:S102-6.

WHO - World Health Organization. Food based dietary guidelines in the WHO European Region. Copenhagen: WHO; 2003 [acesso em 14 set 2012]. Disponível em: http://www.euro.who.int/_data/assets/pdf_file/0017/150083/E79832.pdf

WHO - World Health Organization. Global Strategy on Diet, Physical Activity and Health. Copenhagen: WHO; maio 2004 [acesso em 15 set 2012]. Disponível em: http://www.who.int/dietphysicalactivity/strategy/eb11344/en/index.html

Wojcicki JM1, Heyman MB. Adolescent nutritional awareness and use of food labels: results from the National Nutrition Health and Examination Survey. BMC Pediatr. 2012 May 28;12:55.

Zepeda L, Sirieix L, Pizarro A, Corderre F, Rodier F. A conceptual framework for analyzing consumers' food label preferences: an exploratory study of sustainability labels in France, Quebec, Spain and the US. Int J Consum Stud. 2013;37(6):605-16. DOI:10.1111/ijcs.12041. 